\title{
Evaluation of Groundwater Impacts to Support the National Environmental Policy Act Environmental Assessment for the INL Remote-Handled Low-Level Waste Disposal Project
}

August 2011

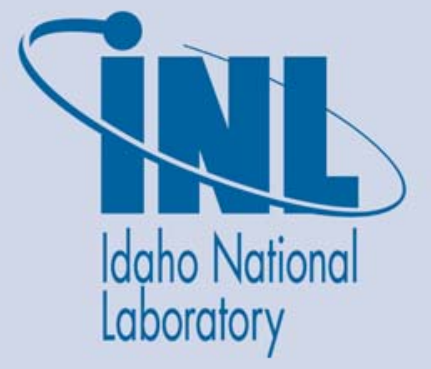

The INL is a U.S. Department of Energy National Laboratory operated by Battelle Energy Alliance 
DISCLAIMER

This information was prepared as an account of work sponsored by an agency of the U.S. Government. Neither the U.S. Government nor any agency thereof, nor any of their employees, makes any warranty, expressed or implied, or assumes any legal liability or responsibility for the accuracy, completeness, or usefulness, of any information, apparatus, product, or process disclosed, or represents that its use would not infringe privately owned rights. References herein to any specific commercial product,

process, or service by trade name, trade mark, manufacturer, or otherwise, does not necessarily constitute or imply its endorsement, recommendation, or favoring by the U.S. Government or any agency thereof. The views and opinions of authors expressed herein do not necessarily state or reflect those of the U.S. Government or any agency thereof. 


\section{Evaluation of Groundwater Impacts to Support the National Environmental Policy Act Environmental Assessment for the INL Remote-Handled Low-Level Waste Disposal Project}

\section{Idaho National Laboratory}

Idaho Falls, Idaho 83415

http://www.inl.gov

Prepared for the U.S. Department of Energy Office of Nuclear Energy Under DOE Idaho Operations Office Contract DE-AC07-05ID14517 



\begin{abstract}
Groundwater impacts have been analyzed for the proposed remote-handled low-level waste disposal facility. The analysis was prepared to support the National Environmental Policy Act environmental assessment for the top two ranked sites for the proposed disposal facility. A four-phase screening and analysis approach was documented and applied. Phase I screening was site independent and applied a radionuclide half-life cut-off of 1 year. Phase II screening applied the National Council on Radiation Protection analysis approach and was site independent. Phase III screening used a simplified transport model and site-specific geologic and hydrologic parameters. Phase III neglected the infiltration-reducing engineered cover, the sorption influence of the vault system, dispersion in the vadose zone, vertical dispersion in the aquifer, and the release of radionuclides from specific waste forms. These conservatisms were relaxed in the Phase IV analysis which used a different model with more realistic parameters and assumptions.
\end{abstract}

Phase I screening eliminated 143 of the 246 radionuclides in the inventory from further consideration because each had a half-life less than 1 year. An additional 13 were removed because there was no ingestion dose coefficient available. Of the 90 radionuclides carried forward from Phase I, 57 radionuclides had simulated Phase II screening doses exceeding $0.4 \mathrm{mrem} /$ year. Phase III and IV screening compared the maximum predicted radionuclide concentration in the aquifer to maximum contaminant levels. Of the 57 radionuclides carried forward from Phase II, six radionuclides were identified in Phase III as having simulated future aquifer concentrations exceeding maximum contaminant limits. An additional seven radionuclides had simulated Phase III groundwater concentrations exceeding $1 / 100^{\text {th }}$ of their respective maximum contaminant levels and were also retained for Phase IV analysis. The Phase IV analysis predicted that none of the thirteen remaining radionuclides would exceed the maximum contaminant levels for either site location. The predicted cumulative effective dose equivalent from all 13 radionuclides also was less than the dose criteria set forth in Department of Energy Order 435.1 for each site location. An evaluation of composite impacts showed one site is preferable over the other based on the potential for commingling of groundwater contamination with other facilities. 


\section{CONTENTS}

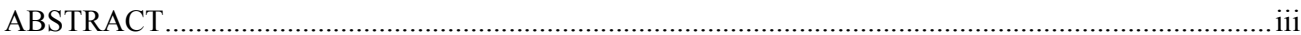

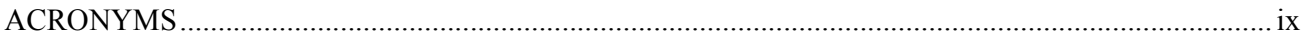

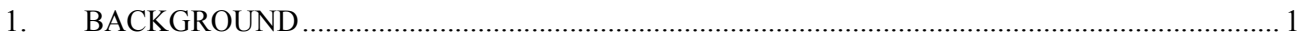

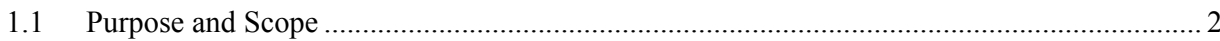

2. EXPOSURE PATHWAYS AND PERFORMANCE MEASURES ................................................ 3

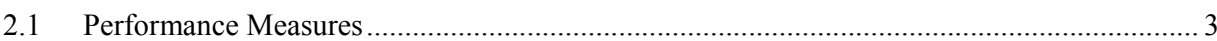

2.1.1 State of Idaho and Environmental Protection Agency Groundwater

Protection Standards ......................................................................................... 4

2.1.2 DOE Order 435.1 Groundwater Protection Standard …......................................... 4

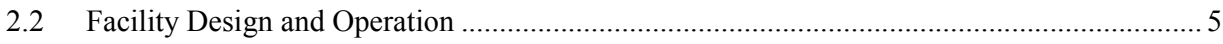

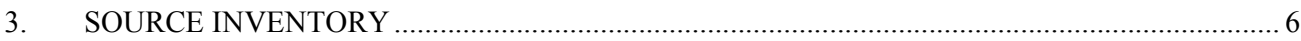

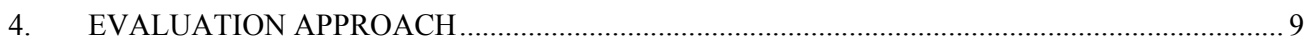

4.1 Phase I: Radionuclide Half-Life Screening.................................................................... 9

4.2 Phase II: National Council on Radiation Protection Screening ......................................... 10

4.3 Phase III: Site-Specific Transport Screening .................................................................... 12

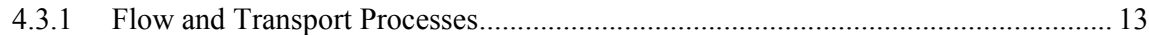

4.3.2 Phase III Model Parameterization......................................................................... 14

4.4 Phase IV: Detailed Source Release with Site-Specific Transport ......................................... 23

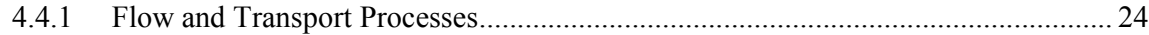

4.4.2 Phase IV Model Parameterization........................................................................ 30

5. RESULTS

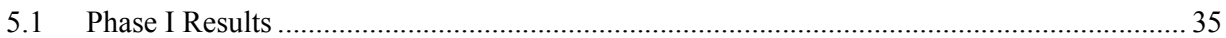

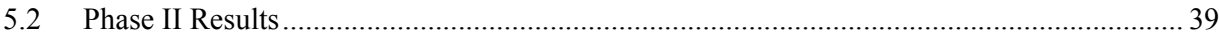

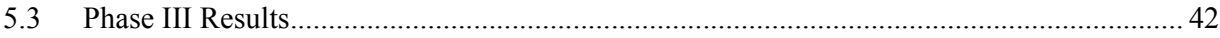

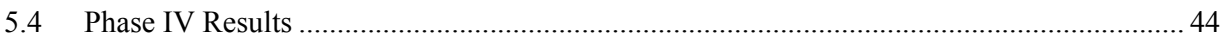

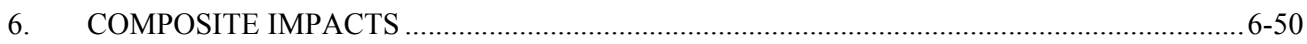

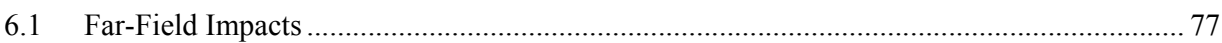


7. SUMMARY

Appendix A, Assessment of Groundwater Impacts from Sources Upgradient of the RemoteHandled Low-Level Waste Disposal Facility Candidate Site 5

\section{FIGURES}

1. Highest ranked candidate sites for the proposed remote-handled low-level waste disposal facility . .1

2. Simplified conceptual model of the groundwater ingestion pathway.....................................2

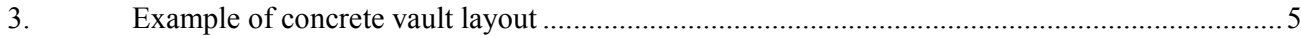

4. Preliminary cover design for the Idaho National Laboratory remote-handled low-level waste disposal facility

5. Conceptual model of transport implemented in this analysis ................................................ 12

6. Geologic cross-section showing sedimentary interbed elevations and thicknesses near Site 5 southeast of the Advanced Test Reactor Complex

7. Location of the geologic cross-section near Site 5 shown in Figure 6

8. North-south geologic cross-section (A-A') at the Idaho Nuclear Technology and Engineering Center near Site 34

9. Location of the north-south geologic cross-section (A-A') at the Idaho Nuclear Technology and Engineering Center shown in Figure 8

10. The mixing cell conceptual model for water flow (left) and contaminant transport (right)

11. Discretization of the cement-sand-vault system, alluvial base layer, basalt, and sedimentary interbeds used to represent the subsurface at Site 5

12. Discretization of the cement-sand-vault system, alluvial base layer, basalt, and sedimentary interbeds used to represent the subsurface at Site 34

13. Ratio of predicted concentration to the maximum contaminant level for each radionuclide based on peak groundwater concentrations predicted during Phase III analysis for Site 5 
14. Ratio of predicted concentration to the maximum contaminant level for each radionuclide based on peak groundwater concentrations predicted during Phase III analysis for Site 34

15. All-pathways EDE as a function of calendar year for Site 5. Pu-239, Pu-240, and $\mathrm{Np}-237$ are not shown because their doses are less than $0.001 \mathrm{mrem} /$ year

16. All-pathways EDE as a function of calendar year for Site 34. Pu-239, Pu-240, and $\mathrm{Np}-237$ are not shown because their doses are less than $0.001 \mathrm{mrem} /$ year

17. Location of the Idaho CERCLA Disposal Facility complex . .76

18. Sum of simulated beta-emitting radionuclide concentrations divided by respective drinking water limits for 2005

19. Sum of simulated beta-emitting radionuclide concentrations divided by respective drinking water limits for 2095

\section{TABLES}

1. Projected 50-year inventory of remote-handled low-level waste

2. Input parameters used for Phase III screening calculations

3. Corrosion rates and fractional release rates for buried metals in Idaho National Laboratory soils

4. Distribution coefficients used in the Phase IV screening analysis ............................................... 34

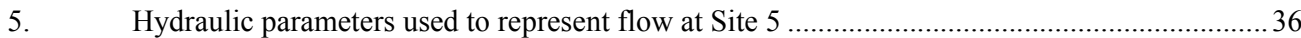

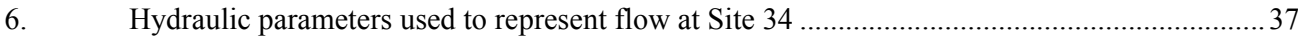

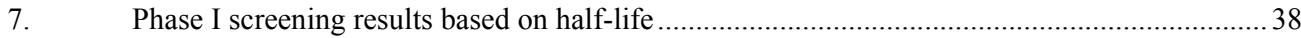

8. Phase II screening results using the National Council on Radiation Protection screening factors

9. Phase III screening results based on site-specific transport ...................................................42

10. Predicted peak radionuclide concentrations in groundwater and time of occurrence for Candidate Sites 5 and 34

11. Peak predicted all-pathways doses and time of occurrence for Candidate Sites 5 and $34 \ldots \ldots . . .47$

12. Summary of primary potential dose contributions to predicted doses for Site $5 \ldots \ldots \ldots \ldots \ldots \ldots \ldots . .74$

13. Potential doses from Operable Unit 3-14 soils scaled from reanalysis of Naval Reactors Facility releases 
14. Summary of primary potential dose contributions to predicted doses from the remote-

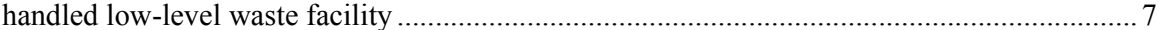




\section{ACRONYMS}

$\begin{array}{ll}\text { ATR } & \text { Advanced Test Reactor } \\ \text { CERCLA } & \text { Comprehensive Environmental Response Compensation and Liability Act } \\ \text { DOE } & \text { Department of Energy } \\ \text { EDE } & \text { effective dose equivalent } \\ \text { ICDF } & \text { INL CERCLA Disposal Facility } \\ \text { INL } & \text { Idaho National Laboratory } \\ \text { INTEC } & \text { Idaho Nuclear Technology and Engineering Center } \\ \text { K } & \text { distribution coefficient } \\ \text { LLW } & \text { low-level waste } \\ \text { MCL } & \text { maximum contaminant level } \\ \text { MCM } & \text { mixing cell model } \\ \text { NCRP } & \text { National Council on Radiation Protection } \\ \text { NRF } & \text { Naval Reactors Facility } \\ \text { OU } & \text { operable unit } \\ \text { RH } & \text { remote-handled } \\ \text { RI/FS } & \text { remedial investigation and feasibility study } \\ \text { RWMC } & \text { Radioactive Waste Management Complex } \\ \text { WAG } & \text { waste area group }\end{array}$




\section{Evaluation of Groundwater Impacts to Support the National Environmental Policy Act Environmental Assessment for the INL Remote-Handled Low-Level Waste Disposal Project}

\section{BACKGROUND}

Since 1952, all remote-handled low-level waste (RH-LLW) generated at the Idaho National Laboratory (INL) has been disposed of at the Subsurface Disposal Area of the Radioactive Waste Management Complex (RWMC). In anticipation of closure of RWMC, INL is proposing to establish a new RH-LLW disposal facility. In compliance with the National Environmental Policy Act (42 USC $\$ 4321$ et seq.), an evaluation of the impacts on the human environment must be conducted. In this case, it will require evaluation of the two highest ranked candidate sites (Harvego et al. 2010).

The two highest ranked sites are located (1) southwest of the Advanced Test Reactor (ATR) Complex (Site 5) and (2) southwest of the Idaho Nuclear Technology and Engineering Center (INTEC) (Site 34) (see Figure 1). These sites are similar demographically and climatographically. They are both located near the ephemeral Big Lost River and are roughly equidistant (about $450 \mathrm{ft}$ ) above the underlying Snake River Plain Aquifer. Contaminants released from either of these facilities could be transported downward through the stratigraphic layers comprising the vadose zone and into the aquifer. This assessment estimates future groundwater impacts by calculating groundwater concentrations and comparing them to Federal drinking water standards. It also calculates a future cumulative all-pathways effective dose equivalent (EDE) and compares it to the dose criteria set forth in DOE Order 435.1, "Radioactive Waste Management."

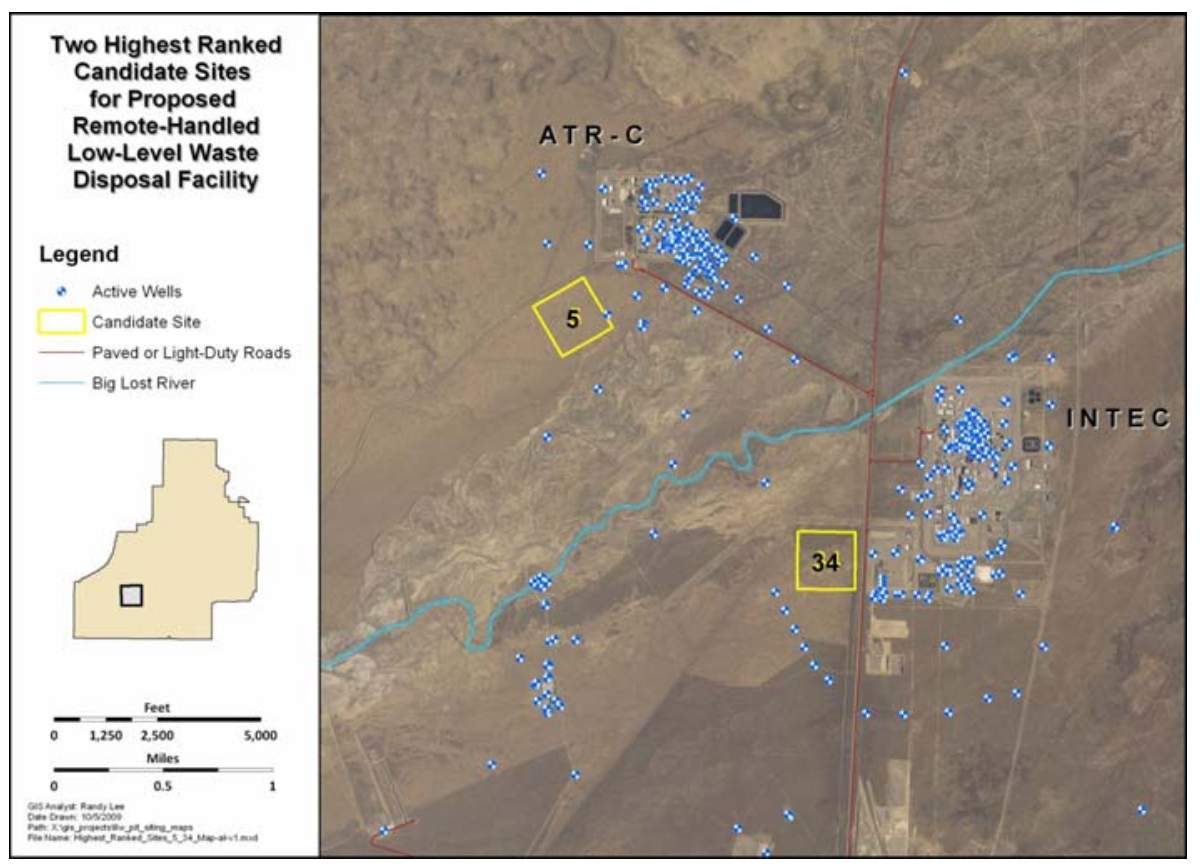

Figure 1. Highest ranked candidate sites for the proposed remote-handled low-level waste disposal facility. 


\subsection{Purpose and Scope}

The purpose of this document is to assess future groundwater impacts for the proposed RH-LLW disposal facility at INL. It includes an evaluation of radionuclide transport from the facility to a hypothetical receptor via the groundwater pathway and compares screening level predictions of groundwater concentrations to federal drinking water standards. The evaluation supports the National Environmental Policy Act environmental assessment of the two highest ranked candidate sites for the proposed facility. The groundwater pathway from the disposal facility to the aquifer is illustrated in Figure 2. Radiologic doses via the groundwater pathway are governed by the release of radionuclides from the waste form to the vadose zone, radioactive decay and hydrodynamic dispersion during transit in the vadose zone en route to the aquifer, and dilution in the aquifer. Residence time in the vadose zone is controlled by the infiltration rate, vadose zone sediment thickness, and sorption. The residence time in the vadose zone allows for decay of the parent radionuclide and ingrowth and decay of progeny. The decay rate also is radionuclide specific and is determined by the half-life of each radionuclide. Sorption serves to retard the rate of downward migration and is dependent on water chemistry and solid surfaces in addition to being radionuclide specific. Dilution in the aquifer is controlled by the flux of radionuclides into the aquifer, the Darcy velocity in the aquifer underlying the disposal facility, and hydrodynamic dispersion. The aquifer velocity is spatially variable underlying INL and is site specific.

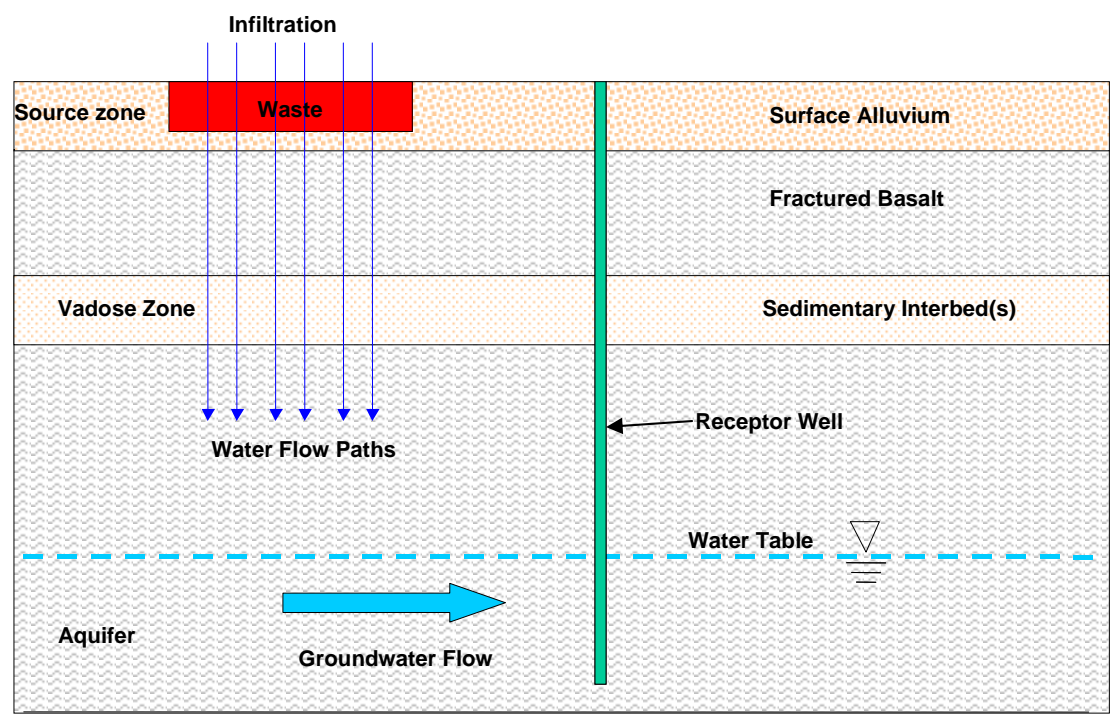

Figure 2. Simplified conceptual model of the groundwater ingestion pathway.

The initial inventory consists of radionuclides with a wide range of sorption characteristics and a wide range of half-lives. Radionuclides with very short half-lives will decay before a significant quantity leaches from the waste or moves through the vadose zone to the aquifer. Highly sorptive radionuclides with short-to-intermediate half-lives also will decay en route to the aquifer. Radionuclides with longer half-lives and those that sorb marginally to vadose zone sediment have a greater likelihood of reaching the aquifer. The concentrations in the aquifer, combined with their radiological dose from groundwater ingestion, determine the impact to groundwater. 
The design of the facility, including an engineered barrier (cover), and the initial inventory are assumed to be site independent. Thus, the availability of radionuclides for transport from the waste zone is site independent. This allows consideration of a one source model, including desorption of radionuclides from resins, corrosion and dissolution of radionuclides from activated metals, and surface release of waste from contaminated debris. However, the characteristics of vadose zone sediment are site-specific, as is the aquifer velocity. Site-specific parameters include thickness, hydraulic conductivity-moisture content relationships, texture, and sorption characteristics of vadose zone sediment. Dispersivity in the aquifer and vadose zone are considered to be site independent.

Because of the large number of radionuclides in the source term and the complexity of the source waste zone and site-specific transport, a four-step analysis approach was used to assess groundwater impacts from the proposed facility. Each step incorporates more complexity and progressively less conservative assumptions to screen out inconsequential radionuclides; therefore, resources can be focused on the radionuclides that have the most impact on groundwater and potential dose. The approach begins with a half-life screening step designed to remove from further consideration those radionuclides that would decay to inconsequential activity levels while enroute to the aquifer. Phase II of the analysis applies screening factors developed by the National Council on Radiation Protection (NCRP; NCRP 1996) to further reduce the inventory of concern to radionuclides that would exceed dose limits to a future hypothetical receptor based on direct ingestion of groundwater prior to transport from the waste zone. Phase III introduces conservative vadose zone transport assumptions, incorporating infiltration, sitespecific sediment thicknesses and sorption properties, and site-specific aquifer velocities, while considering instantaneous release from the waste to the top of the vadose zone. Phase IV introduces key characteristics of the waste zone and its effect on the release rate of contaminants into the vadose zone in addition to accounting for dispersivity.

\section{EXPOSURE PATHWAYS AND PERFORMANCE MEASURES}

Exposure scenarios are the link between contaminated environmental media and the exposure of a hypothetical receptor. They are essentially statements and parameter values that describe the behavior of a hypothetical receptor. Only the drinking water scenario was considered in this analysis. This scenario assumes a receptor consumes 2 L of water per day for 365 days/year per 40 CFR 141, "National Primary Drinking Water Regulations." The receptor is located downgradient of the RH-LLW disposal facility for all times following facility closure; in Phase III screening (described in Section 4.3), the receptor is immediately downgradient of the facility; and in Phase IV, the receptor distance corresponds to the distance required under Department of Energy (DOE) Order 435.1, "Radioactive Waste Management," (100 m downgradient of the downgradient edge of the facility).

\subsection{Performance Measures}

Two performance measures were used to evaluate predicted impacts to the groundwater from the onsite RH-LLW disposal facility alternatives to evaluate protection of groundwater resources. The first standard is required by the Environmental Protection Agency and the State of Idaho, the second standard is more comprehensive and is required to be met by DOE Order 435.1. Descriptions and methods of application are provided below for each of the standards. Both standards require determination of the future radionuclide-specific concentrations in groundwater for each radionuclide. Computation of radionuclide-specific concentrations is described in the Phase III and Phase IV screening steps. 


\subsubsection{State of Idaho and Environmental Protection Agency Groundwater Protection Standards}

Groundwater protection standards are determined by the Environmental Protection Agency and the State of Idaho and are couched in terms of maximum contaminant levels (MCLs). Federal MCLs found in 40 CFR 141 include values for beta-gamma emitting radionuclides and alpha-emitting radionuclides. The MCL for beta-gamma emitting radionuclides is the concentration that, assuming an ingestion rate of $2 \mathrm{~L}$ of water per day for 365 days per year, the dose equivalent to the whole body or critical organ does not exceed $4 \mathrm{mrem} /$ year. Other specific limits include a maximum gross alpha activity of $15 \mathrm{pCi} / \mathrm{L}$ (excluding radon and uranium isotopes), a maximum combined Ra-226 and Ra-228 concentration of $5 \mathrm{pCi} / \mathrm{L}$, a maximum uranium mass concentration of $30 \mu \mathrm{g} / \mathrm{L}$, and maximum $\mathrm{H}-3$ and $\mathrm{Sr}-90$ concentrations of $20,000 \mathrm{pCi} / \mathrm{L}$ and $8 \mathrm{pCi} / \mathrm{L}$, respectively.

MCLs for beta-gamma emitting radionuclides are based on a whole body and critical organ dose equivalent limit of $4 \mathrm{mrem} / \mathrm{year}$. The whole body and critical organ doses are calculated using the dose coefficients in the National Bureau of Standards Handbook 69, "Maximum Permissible Body Burdens and Maximum Permissible Concentration of Radionuclides in Air and Water for Occupational Exposure," (NBS 1963). The dose coefficients in National Bureau of Standards Handbook 69 are based on International Commission on Radiation Protection Publication 2, which has been superseded by International Commission on Radiation Protection Publication 30, and more recently, International Commission on Radiation Protection Publication 72 (ICRP 72 1995). Dose coefficients from the National Bureau of Standards Handbook 69 for all radionuclides in the RH-LLW inventory are not available. Where the MCL is unpublished, a dose of $4.0 \mathrm{mrem} / \mathrm{year}$ EDE was used in this analysis to compute the corresponding MCL using dose coefficients from Federal Guidance Report 13 (EPA 1999) and the corresponding supplement (EPA 2002).

\subsubsection{DOE Order 435.1 Groundwater Protection Standard}

The dose limit prescribed in DOE Order 435.1 for performance of low-level waste facilities is 25 $\mathrm{mrem} / \mathrm{yr}$ effective dose equivalent (EDE) through all pathways. The all-pathways EDE was computed using an all-pathways model described DOE-ID (2007a), developed and approved in support of the DOE Order 435.1 documentation and disposal approval process for the active LLW disposal facility at RWMC. Unless otherwise stated, the term dose in this documented refers to the effective dose equivalent which is defined as the sum of the 50-year committed organ dose equivalent times the organ weighting factor for internally deposited radionuclides (via ingestion and inhalation), and the organ dose equivalent times the organ weighting factor for exposure to gamma-emitting radionuclides external to the body (external exposure). The all-pathways EDE considers dose received by direct ingestion of groundwater and dose from using groundwater to irrigate human and animal crops and water animals. The allpathways EDE includes dose from ingestion of locally grown crops, locally raised beef, and locally produced milk. The all-pathways EDE is summarized in terms of the all-pathways dose per unit concentration in groundwater. With these factors, the dose can be calculated by multiplying the predicted groundwater concentration by the all-pathways dose factor:

$D=C_{G W} * D C F$

where

$D=$ annual all-pathways EDE from the groundwater pathway (mrem/year)

$C_{G W}=$ radionuclide concentration in groundwater $\left(\mathrm{Ci} / \mathrm{m}^{3}\right)$

$D C F=$ all-pathways dose factor from DOE-ID (2007a) (mrem-m ${ }^{3} / \mathrm{Ci}$-year).

Using an all-pathways EDE for the assessment of each alternative onsite disposal option allows the cumulative effects to be determined through time as opposed to measuring the effect of each radionuclide 
individually. Additionally, the predicted all-pathways EDE from the individual onsite alternatives can be compared to all-pathways EDE from other facilities; namely RWMC, the Idaho CERCLA Disposal Facility (ICDF), and the Tank Farm Facility at INTEC.

\subsection{Facility Design and Operation}

According to the conceptual design report (INL 2010a), the proposed INL RH-LLW disposal facility will accept two primary types of RH-LLW: activated metals and ion-exchange resins. Small amounts of miscellaneous debris waste also will be included. The waste will be contained in sealed liners made of steel. The liners will be placed in concrete disposal vaults at the disposal facility. The disposal vaults will be constructed as precast concrete cylinders (i.e., pipe sections) stacked on end and placed in a closepacked array as shown in Figure 3. All vaults will be supported by reinforced concrete base sections placed atop a gravel layer and covered with removable hexagonal precast concrete plugs. The plugs serve as a radiation shield for emplaced waste and should help prevent water from entering the vaults. The area around the vaults will be backfilled with sand for stability and to promote drainage away from the facility.

During the 2016 through 2065 operational period, the containers and vaults will provide sufficient barriers from water and air such that negligible transport of contaminants into the environment will occur. At the end of the operational period, the disposal facility will be closed.

At the end of the operational life of the disposal facility, a protective cover will be placed over the waste disposal vaults (Figure 4). The primary purposes of the cover are to (1) minimize infiltration into the disposal facility after facility closure, reducing leachate generation and contaminant transport, and (2) provide a barrier against intrusion. In addition to infiltration and intrusion-limiting features, the cover will include armoring on the sides to prevent wind and rain erosion. The cover will be configured to divert surface water away from the vaults and extend beyond the boundary of the facility. The cover dimensions, layer thicknesses, and other specifications will be determined prior to facility closure and be based on the final size and configuration of the facility. The cover also will incorporate criteria identified in the facility performance assessment.

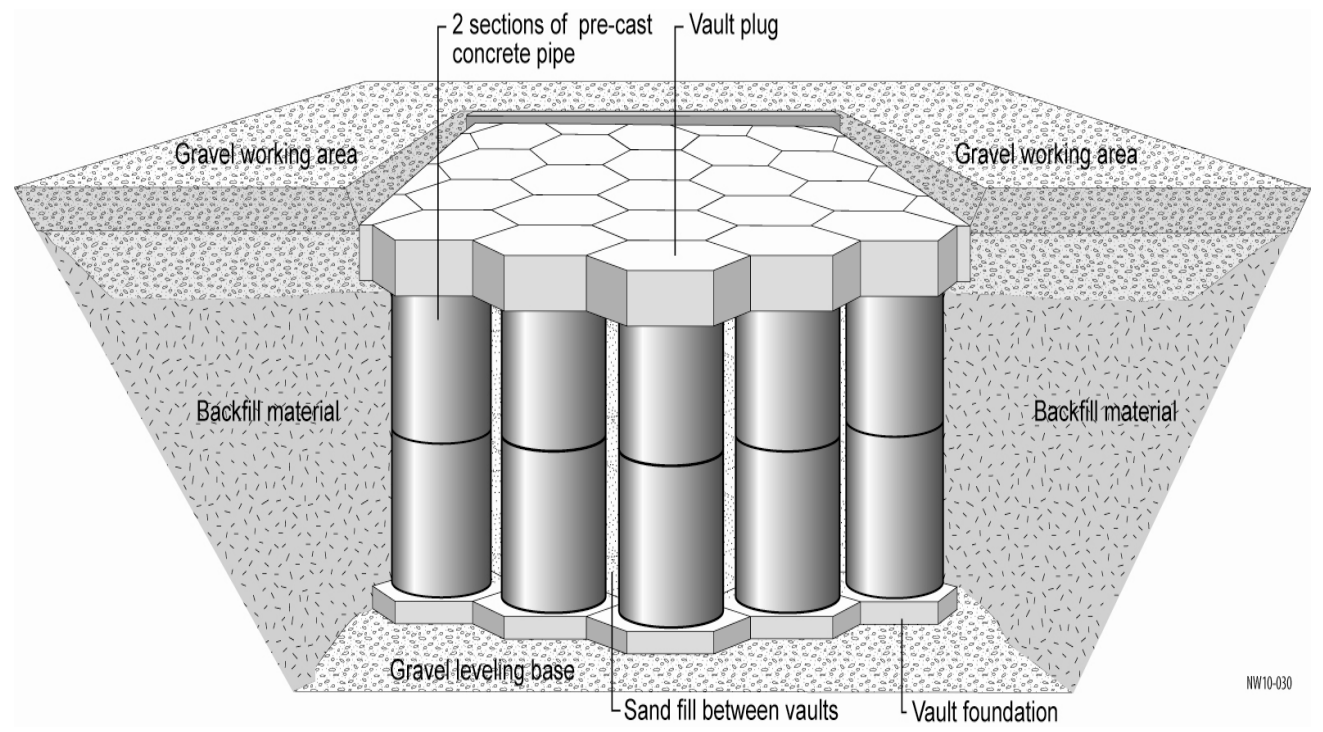

Figure 3. Example of concrete vault layout (INL 2010a). 


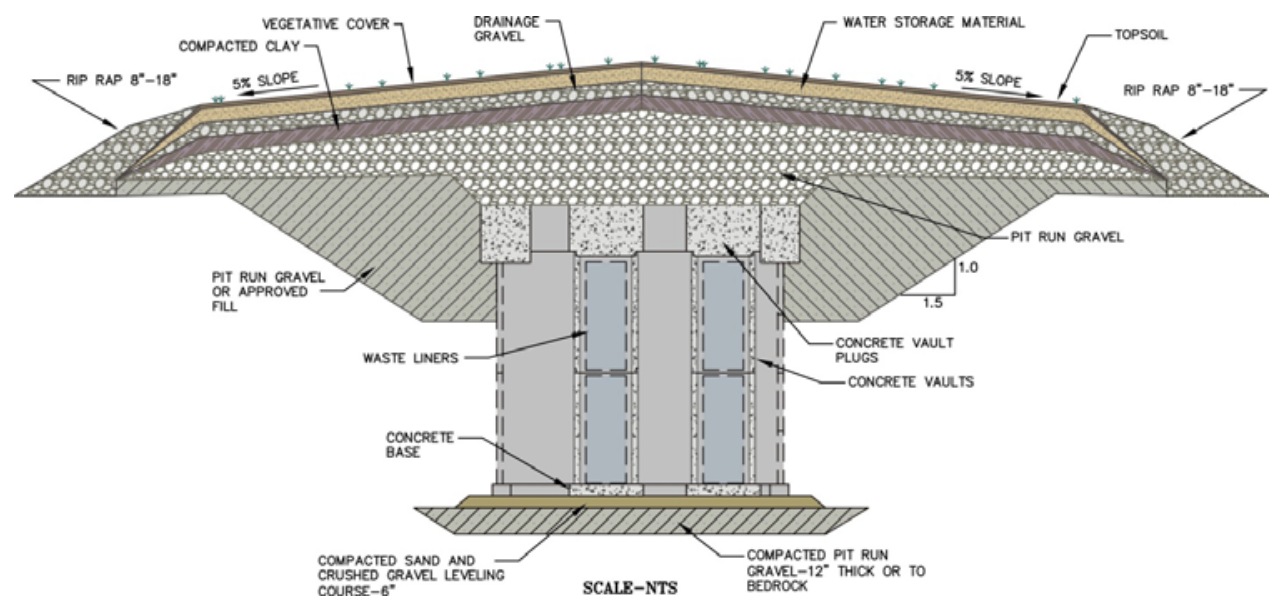

Figure 4. Preliminary cover design for the Idaho National Laboratory remote-handled low-level waste disposal facility.

\section{SOURCE INVENTORY}

The disposal facility will accept three primary types of RH-LLW: activated metals, ion-exchange resins, and miscellaneous contaminated debris. The activated metals are generated by ATR Complex operations, Naval Reactors Facility (NRF) operations, and from processing waste stored in the Radioactive Scrap and Waste Facility at the Materials and Fuels Complex. The activated metals are typically reactor core components replaced during core internal changeouts and are made from stainless steel, inconel, zircaloy, or aluminum. The ion-exchange resins are ceramic beads used to purify reactor cooling water as part of routine operations at the ATR Complex and to purify pool water at NRF.

The design life of the proposed RH-LLW disposal facility is 50 years. Disposal inventories for a 50 -year period have been projected by each of the waste generators; the combined inventory from all generators, in terms of activity, is shown in Table 1. The following is a list and description of the inventory reports produced by the waste generators:

1. Estimate of the Radionuclide Content of Future Activated Metal Generation at ATR from 2016 to $\underline{2065}$ (ECAR-854 2009). This report includes the projected inventory of activation in reactor hardware from core internal changeouts of the ATR. The changeouts occur approximately every 10 years. Over a 50 -year period, it is assumed that the waste from six changeouts would be disposed of at the proposed RH-LLW facility.

2. Estimate of Radionuclide Content of Future Resins Generation at ATR from 2016 to 2065 (ECAR-851 2009). This report estimates that approximately $1,200 \mathrm{~m}^{3}$ of radioactively contaminated ion-exchange resins would be generated over a 50 -year period.

3. Long-Range Radioactivity Estimate for NRF RH-LLW (NRF 2011). This report includes projections of activation and fission products in activated metals and resins for a 50 -year period. The metal inventory differentiates the amount integral to the metal and the amount on the surface.

4. A Methodology for Retrofitting Source Terms to Previously Inadequately Characterized Experimental Breeder Reactor-II Irradiated Reactor Hardware as Waste (Source Term and Volume Estimate for Materials and Fuels Complex-Generated RH-LLW from 2016 to 2065 (ECAR-904 2010). This report includes an estimate of the radionuclide inventory in Experimental Breeder Reactor-II irradiated hardware currently stored at the Radioactive Scrap and Waste Facility. 
5. Source Term and Volume Estimate for Materials and Fuels Complex Generated RH-LLW from 2016 to 2065 (ECAR-967 2010). This report includes the radionuclide inventory in/on miscellaneous debris and trash that is 1) currently stored at the Radioactive Scrap and Waste Facility (legacy waste) and 2) will be generated over the next 50 years from routine operations at the Materials and Fuels Complex (future generation waste).

Table 1. Projected 50-year inventory of remote-handled low-level waste.

\begin{tabular}{|c|c|c|c|c|c|}
\hline Radionuclide & $\begin{array}{l}\text { Total Inventory } \\
\text { (Ci) }\end{array}$ & Radionuclide & $\begin{array}{c}\text { Total Inventory } \\
\text { (Ci) }\end{array}$ & Radionuclide & $\begin{array}{c}\text { Total Inventory } \\
\text { (Ci) }\end{array}$ \\
\hline Ac- 225 & 6.39E-08 & In-114m & $4.41 \mathrm{E}+00$ & Re-186 & $6.35 \mathrm{E}-06$ \\
\hline Ac- 227 & $1.85 \mathrm{E}-06$ & In-115 & $4.91 \mathrm{E}-13$ & Re-187 & 8.94E-01 \\
\hline Ac- 228 & $2.96 \mathrm{E}-07$ & In- $115 \mathrm{~m}$ & $1.15 \mathrm{E}-09$ & Re-188 & 8.03E-01 \\
\hline $\mathrm{Ag}-108$ & $2.58 \mathrm{E}-06$ & Ir-192 & $9.46 \mathrm{E}-02$ & Rh-102 & $1.23 \mathrm{E}-04$ \\
\hline $\mathrm{Ag}-108 \mathrm{~m}$ & 2.92E-05 & Ir-192m & $1.11 \mathrm{E}-05$ & $\mathrm{Rh}-103 \mathrm{~m}$ & $4.71 \mathrm{E}-02$ \\
\hline Ag-109m & $3.65 \mathrm{E}-01$ & Ir-194 & 4.08E-09 & Rh-106 & $3.12 \mathrm{E}+03$ \\
\hline Ag-110 & $1.19 \mathrm{E}-03$ & Ir-194m & $9.95 \mathrm{E}-03$ & Rn-219 & $1.85 \mathrm{E}-06$ \\
\hline $\mathrm{Ag}-110 \mathrm{~m}$ & $1.41 \mathrm{E}-01$ & $\mathrm{~K}-40$ & $1.26 \mathrm{E}-03$ & Rn-220 & $2.87 \mathrm{E}-04$ \\
\hline Ag-111 & $4.70 \mathrm{E}+03$ & K-42 & $5.51 \mathrm{E}-12$ & Rn-222 & $8.00 \mathrm{E}-11$ \\
\hline Am-241 & $3.91 \mathrm{E}-01$ & $\mathrm{Kr}-81$ & $4.51 \mathrm{E}-12$ & Ru-103 & $8.28 \mathrm{E}+04$ \\
\hline Am-242 & $2.72 \mathrm{E}-03$ & $\mathrm{Kr}-85$ & $2.64 \mathrm{E}+02$ & Ru-106 & $3.12 \mathrm{E}+03$ \\
\hline Am- $242 m$ & $2.76 \mathrm{E}-03$ & La-137 & $2.38 \mathrm{E}-06$ & S-35 & $5.57 \mathrm{E}+00$ \\
\hline Am-243 & $1.03 \mathrm{E}-03$ & La-140 & $8.70 \mathrm{E}+04$ & $\mathrm{Sb}-124$ & $6.09 \mathrm{E}+00$ \\
\hline Ar-37 & $1.24 \mathrm{E}-02$ & Lu-176 & $1.50 \mathrm{E}-08$ & $\mathrm{Sb}-125$ & $3.53 \mathrm{E}+04$ \\
\hline Ar-39 & $5.01 \mathrm{E}-02$ & Lu-177 & $1.54 \mathrm{E}-02$ & $\mathrm{Sb}-126$ & $2.66 \mathrm{E}-05$ \\
\hline Ar-42 & $5.51 \mathrm{E}-12$ & Lu-177m & $7.05 \mathrm{E}-02$ & $\mathrm{Sb}-126 \mathrm{~m}$ & $1.91 \mathrm{E}-04$ \\
\hline As-76 & 2.07E-02 & Mn-54 & $8.71 \mathrm{E}+05$ & Sc-46 & $5.74 \mathrm{E}+00$ \\
\hline At-217 & $6.38 \mathrm{E}-08$ & Mo-93 & $2.91 \mathrm{E}+01$ & Se-75 & $1.76 \mathrm{E}+01$ \\
\hline Ba-133 & $1.83 \mathrm{E}-03$ & Mo-99 & 8.36E-01 & Se-79 & $8.44 \mathrm{E}-03$ \\
\hline Ba-136m & $3.44 \mathrm{E}-10$ & $\mathrm{Na}-24$ & $9.21 \mathrm{E}-06$ & $\mathrm{Si}-32$ & $6.65 \mathrm{E}-07$ \\
\hline Ba-137m & $5.92 \mathrm{E}+03$ & $\mathrm{Nb}-92$ & $5.93 \mathrm{E}-06$ & Sm-147 & $4.38 \mathrm{E}-10$ \\
\hline Ba-140 & $7.60 \mathrm{E}+04$ & $\mathrm{Nb}-93 \mathrm{~m}$ & $6.98 \mathrm{E}+02$ & Sm-151 & $4.86 \mathrm{E}+01$ \\
\hline Be-10 & $1.80 \mathrm{E}-04$ & $\mathrm{Nb}-94$ & $1.11 \mathrm{E}+02$ & Sn-113 & $5.03 \mathrm{E}+03$ \\
\hline Bi-208 & $3.17 \mathrm{E}-07$ & $\mathrm{Nb}-95$ & $2.40 \mathrm{E}+05$ & Sn-117m & $7.53 \mathrm{E}+02$ \\
\hline $\mathrm{Bi}-210 \mathrm{~m}$ & $1.09 \mathrm{E}-06$ & $\mathrm{Nb}-95 \mathrm{~m}$ & $5.97 \mathrm{E}+02$ & Sn-119m & $5.10 \mathrm{E}+04$ \\
\hline Bi-211 & $1.85 \mathrm{E}-06$ & Nd-147 & $3.86 \mathrm{E}+04$ & Sn-121 & $1.07 \mathrm{E}+02$ \\
\hline Bi-212 & $2.86 \mathrm{E}-04$ & Ni-59 & $3.24 \mathrm{E}+03$ & Sn- $121 \mathrm{~m}$ & $1.38 \mathrm{E}+02$ \\
\hline $\mathrm{Bi}-213$ & $6.38 \mathrm{E}-08$ & $\mathrm{Ni}-63$ & $3.92 \mathrm{E}+05$ & Sn-123 & $2.37 \mathrm{E}+01$ \\
\hline Bi-214 & $8.00 \mathrm{E}-11$ & Np-235 & 2.49E-09 & Sn-125 & $1.04 \mathrm{E}+03$ \\
\hline Bk-249 & $2.05 \mathrm{E}-09$ & Np-236 & $1.24 \mathrm{E}-11$ & Sn-126 & $1.98 \mathrm{E}-04$ \\
\hline
\end{tabular}


Table 1. (continued).

\begin{tabular}{|c|c|c|c|c|c|}
\hline Radionuclide & $\begin{array}{c}\text { Total Inventory } \\
(\mathrm{Ci})\end{array}$ & Radionuclide & $\begin{array}{l}\text { Total Inventory } \\
(\mathrm{Ci})\end{array}$ & Radionuclide & $\begin{array}{l}\text { Total Inventory } \\
\text { (Ci) }\end{array}$ \\
\hline C-14 & $4.32 \mathrm{E}+02$ & Np-237 & $2.99 \mathrm{E}-03$ & $\mathrm{Sr}-85$ & 5.92E-04 \\
\hline $\mathrm{Ca}-41$ & $1.35 \mathrm{E}-02$ & $\mathrm{~Np}-238$ & $1.22 \mathrm{E}-05$ & Sr-89 & $8.45 \mathrm{E}+04$ \\
\hline $\mathrm{Ca}-45$ & $7.53 \mathrm{E}-01$ & Np-239 & $9.84 \mathrm{E}-04$ & Sr-90 & $6.18 \mathrm{E}+03$ \\
\hline Cd-109 & $3.97 \mathrm{E}-01$ & $\mathrm{~Np}-240 \mathrm{~m}$ & $9.00 \mathrm{E}-13$ & Ta-180 & $6.97 \mathrm{E}-01$ \\
\hline Cd-113m & $5.64 \mathrm{E}-02$ & Os-185 & $1.88 \mathrm{E}-04$ & Ta-182 & $5.69 \mathrm{E}+04$ \\
\hline Cd-115 & $2.69 \mathrm{E}-02$ & Os-191 & $2.75 \mathrm{E}-08$ & Tb-160 & $2.40 \mathrm{E}-04$ \\
\hline Cd-115m & $1.14 \mathrm{E}-04$ & Os-194 & 4.05E-09 & Tc-99 & $1.67 \mathrm{E}+01$ \\
\hline Ce-139 & $5.14 \mathrm{E}-04$ & P-32 & $6.66 \mathrm{E}-06$ & Te-121 & $7.90 \mathrm{E}-03$ \\
\hline Ce-141 & $1.04 \mathrm{E}+05$ & P-33 & $5.88 \mathrm{E}-02$ & $\mathrm{Te}-121 \mathrm{~m}$ & $7.96 \mathrm{E}-03$ \\
\hline Ce-142 & $5.86 \mathrm{E}-07$ & $\mathrm{~Pa}-231$ & $8.81 \mathrm{E}-06$ & Te-123 & 5.07E-09 \\
\hline Ce-144 & $3.78 \mathrm{E}+04$ & $\mathrm{~Pa}-233$ & $1.94 \mathrm{E}-04$ & $\mathrm{Te}-123 \mathrm{~m}$ & $2.83 \mathrm{E}-02$ \\
\hline Cf-249 & $1.02 \mathrm{E}-11$ & $\mathrm{~Pa}-234$ & 3.32E-07 & Te- $125 \mathrm{~m}$ & $8.71 \mathrm{E}+03$ \\
\hline Cf- 250 & $1.47 \mathrm{E}-10$ & $\mathrm{~Pa}-234 \mathrm{~m}$ & $2.89 \mathrm{E}-04$ & Te-127 & $6.33 \mathrm{E}-01$ \\
\hline Cf-251 & $3.25 \mathrm{E}-13$ & $\mathrm{~Pb}-204$ & 4.72E-13 & Te- $127 \mathrm{~m}$ & $6.08 \mathrm{E}+02$ \\
\hline Cf-252 & $3.31 \mathrm{E}-10$ & $\mathrm{~Pb}-205$ & 8.32E-07 & Te-129 & $2.39 \mathrm{E}-04$ \\
\hline $\mathrm{Cl}-36$ & $1.53 \mathrm{E}-01$ & $\mathrm{~Pb}-209$ & $6.38 \mathrm{E}-08$ & Te- $129 \mathrm{~m}$ & $3.18 \mathrm{E}+03$ \\
\hline $\mathrm{Cm}-242$ & $1.25 \mathrm{E}+01$ & $\mathrm{~Pb}-211$ & $1.85 \mathrm{E}-06$ & Te-132 & $5.03 \mathrm{E}+03$ \\
\hline $\mathrm{Cm}-243$ & $1.90 \mathrm{E}-03$ & $\mathrm{~Pb}-212$ & $2.87 \mathrm{E}-04$ & Th-227 & $1.82 \mathrm{E}-06$ \\
\hline $\mathrm{Cm}-244$ & $7.70 \mathrm{E}-02$ & $\mathrm{~Pb}-214$ & $8.00 \mathrm{E}-11$ & Th-228 & $2.89 \mathrm{E}-04$ \\
\hline $\mathrm{Cm}-245$ & $1.50 \mathrm{E}-06$ & Pd-107 & $3.16 \mathrm{E}-04$ & Th-229 & $6.38 \mathrm{E}-08$ \\
\hline $\mathrm{Cm}-246$ & $1.06 \mathrm{E}-06$ & Pm-145 & $1.62 \mathrm{E}-10$ & Th-230 & $6.82 \mathrm{E}-08$ \\
\hline $\mathrm{Cm}-247$ & $4.88 \mathrm{E}-13$ & $\mathrm{Pm}-146$ & 8.44E-08 & Th-231 & 8.37E-06 \\
\hline Cm-248 & $1.54 \mathrm{E}-12$ & Pm-147 & $8.80 \mathrm{E}+03$ & Th-232 & $3.12 \mathrm{E}-07$ \\
\hline $\mathrm{Co}-57$ & $3.97 \mathrm{E}-01$ & Pm-148 & $2.39 \mathrm{E}-05$ & Th-234 & $2.89 \mathrm{E}-04$ \\
\hline Co-58 & $1.08 \mathrm{E}+06$ & $\mathrm{Pm}-148 \mathrm{~m}$ & 4.43E-04 & Tl-204 & $2.19 \mathrm{E}-22$ \\
\hline Co-60 & $2.90 \mathrm{E}+06$ & Po-210 & $3.66 \mathrm{E}-01$ & Tl-206 & $6.08 \mathrm{E}-03$ \\
\hline $\mathrm{Cr}-51$ & $9.92 \mathrm{E}+05$ & Po-211 & 3.02E-09 & Tl-207 & $1.85 \mathrm{E}-06$ \\
\hline Cs-134 & $3.83 \mathrm{E}+02$ & Po-212 & $1.84 \mathrm{E}-04$ & Tl-208 & $1.03 \mathrm{E}-04$ \\
\hline Cs-135 & $1.55 \mathrm{E}-02$ & Po-213 & $6.24 \mathrm{E}-08$ & Tl-209 & $2.95 \mathrm{E}-10$ \\
\hline Cs-136 & $3.10 \mathrm{E}-09$ & Po-214 & $8.00 \mathrm{E}-11$ & Tm-170 & $4.74 \mathrm{E}-11$ \\
\hline Cs-137 & $6.27 \mathrm{E}+03$ & Po-215 & $1.85 \mathrm{E}-06$ & Tm-171 & $3.46 \mathrm{E}-07$ \\
\hline Eu-152 & $1.04 \mathrm{E}+01$ & Po-216 & $2.87 \mathrm{E}-04$ & U-232 & $3.59 \mathrm{E}-04$ \\
\hline Eu-154 & $2.45 \mathrm{E}+02$ & Po-218 & $8.00 \mathrm{E}-11$ & U-233 & $1.18 \mathrm{E}-04$ \\
\hline Eu-155 & $3.90 \mathrm{E}+02$ & Pr-143 & $8.82 \mathrm{E}-08$ & U-234 & $1.20 \mathrm{E}-03$ \\
\hline Eu-156 & $8.30 \mathrm{E}-08$ & Pr-144 & $8.17 \mathrm{E}+04$ & U-235 & $5.14 \mathrm{E}-03$ \\
\hline
\end{tabular}


Table 1. (continued).

\begin{tabular}{|c|c|c|c|c|c|}
\hline Radionuclide & $\begin{array}{l}\text { Total Inventory } \\
\text { (Ci) }\end{array}$ & Radionuclide & $\begin{array}{l}\text { Total Inventory } \\
\text { (Ci) }\end{array}$ & Radionuclide & $\begin{array}{c}\text { Total Inventory } \\
\text { (Ci) }\end{array}$ \\
\hline $\mathrm{Fe}-55$ & $1.19 \mathrm{E}+06$ & Pr- $144 m$ & $5.12 \mathrm{E}-01$ & U-236 & $1.29 \mathrm{E}-04$ \\
\hline $\mathrm{Fe}-59$ & $1.19 \mathrm{E}+05$ & Pt-193 & $9.08 \mathrm{E}-04$ & U-237 & $6.46 \mathrm{E}-04$ \\
\hline Fr-221 & $6.38 \mathrm{E}-08$ & $\mathrm{Pu}-236$ & $7.06 \mathrm{E}-07$ & U-238 & $1.62 \mathrm{E}+01$ \\
\hline Fr-223 & $1.56 \mathrm{E}-08$ & $\mathrm{Pu}-237$ & 4.70E-08 & $\mathrm{U}-240$ & $9.00 \mathrm{E}-13$ \\
\hline Gd-153 & $3.45 \mathrm{E}-01$ & $\mathrm{Pu}-238$ & $6.85 \mathrm{E}-01$ & V-50 & $2.51 \mathrm{E}-11$ \\
\hline $\mathrm{H}-3$ & $3.92 \mathrm{E}+03$ & $\mathrm{Pu}-239$ & 4.67E-01 & W-181 & $6.06 \mathrm{E}+01$ \\
\hline Hf-175 & $2.05 \mathrm{E}+02$ & $\mathrm{Pu}-240$ & $2.48 \mathrm{E}-01$ & W-185 & $3.22 \mathrm{E}+02$ \\
\hline Hf- $178 \mathrm{~m}$ & $4.01 \mathrm{E}-08$ & $\mathrm{Pu}-241$ & $2.71 \mathrm{E}+01$ & W-187 & 8.94E-01 \\
\hline Hf-181 & $1.44 \mathrm{E}+02$ & $\mathrm{Pu}-242$ & $3.85 \mathrm{E}-04$ & W-188 & $1.89 \mathrm{E}-01$ \\
\hline Hf- 182 & $1.15 \mathrm{E}-04$ & $\mathrm{Pu}-244$ & $1.31 \mathrm{E}-12$ & $\mathrm{Xe}-131 \mathrm{~m}$ & $1.42 \mathrm{E}-10$ \\
\hline Ho- $166 \mathrm{~m}$ & $5.57 \mathrm{E}-08$ & $\mathrm{Ra}-223$ & $1.85 \mathrm{E}-06$ & $\mathrm{Xe}-133$ & $3.34 \mathrm{E}+04$ \\
\hline $\mathrm{I}-129$ & $1.33 \mathrm{E}-01$ & Ra-224 & $2.87 \mathrm{E}-04$ & $Y-89 m$ & $3.34 \mathrm{E}-04$ \\
\hline $\mathrm{I}-131$ & $2.52 \mathrm{E}+04$ & $\mathrm{Ra}-225$ & $6.39 \mathrm{E}-08$ & Y-90 & $6.18 \mathrm{E}+03$ \\
\hline $\mathrm{I}-132$ & $5.46 \mathrm{E}-03$ & Ra-226 & $8.00 \mathrm{E}-11$ & Y-91 & $1.06 \mathrm{E}+05$ \\
\hline $\mathrm{I}-133$ & $2.16 \mathrm{E}-02$ & $\mathrm{Ra}-228$ & $2.96 \mathrm{E}-07$ & $\mathrm{Zn}-65$ & $1.38 \mathrm{E}+02$ \\
\hline In-113m & $5.03 \mathrm{E}+03$ & $\mathrm{Rb}-86$ & $2.23 \mathrm{E}-06$ & Zr-93 & $4.37 \mathrm{E}+01$ \\
\hline In-114 & $4.22 \mathrm{E}+00$ & $\mathrm{Rb}-87$ & $1.28 \mathrm{E}-06$ & $\mathrm{Zr}-95$ & $1.81 \mathrm{E}+05$ \\
\hline
\end{tabular}

\section{EVALUATION APPROACH}

Because of the large number of radionuclides identified in the inventory estimates, a four-phase evaluation approach was used to screen out and assess potential groundwater impacts. The first two phases use very simple and conservative site-independent screening methods to eliminate inconsequential radionuclides from further consideration. The third phase uses a conservative model to simulate the release and transport of radionuclides through the subsurface to a hypothetical receptor. The fourth phase incorporates release of radionuclides from specific waste forms, sorption within the waste zone, site-specific sorption parameters for sedimentary interbeds, vadose zone and aquifer dispersion, and the influence of an engineered infiltration reducing cover. Results of Phase III and Phase IV are compared to the MCLs. The details of each screening phase are described in the following subsections.

\subsection{Phase I: Radionuclide Half-Life Screening}

Phase I identifies radionuclides with half-lives sufficiently small that decay would reduce the activity to insignificant levels by the time the radionuclide reaches the aquifer. The resultant activity after transport through the vadose zone is computed from the vadose zone transit time $(T)$ and the half-life of each radionuclide $(\mathrm{t} 1 / 2)$ :

$A(t)=A_{0} * e^{-\lambda T} \quad$ where $\quad \lambda=\frac{\ln (2)}{t_{1 / 2}}$

where $A(t)$ is the activity at time $t, A_{0}$ is the initial activity, and $\lambda$ is the radioactive decay constant. 
Based on a total sediment thickness of $20 \mathrm{~m}$, which is the estimated thickness at Site 5 (see Section 4.3.2.3), a conservative infiltration rate of $10 \mathrm{~cm} /$ year representative of disturbed soil conditions and a corresponding moisture content of 0.30 (DOE-ID 1994, DOE-ID 2007a), the transit time through the vadose zone for a non-sorbing tracer is approximately 60 years. Using Equation 2, after 60 years, a radionuclide with a 5 -year half-life would have $2.4 \times 10^{-4}$ times its original activity, and a radionuclide with a 1-year half-life would have $8.7 \times 10^{-19}$ times the original activity. In the results presented in Section 5, a cut-off of 1 year is applied. Adopting a 1-year cut-off is consistent with the ICDF Performance Assessment (DOE-ID 2010) where a half-life cut-off of 1 year also was applied. Additionally, the 1-year cut-off is consistent with the NCRP groundwater screening approach (NCRP 1996).

\subsection{Phase II: National Council on Radiation Protection Screening}

The NCRP provides a series of simple screening techniques and factors that can be used to demonstrate compliance with environmental standards or other administratively set reference levels for releases of radionuclides to the atmosphere, surface water, or groundwater (NCRP 1996). The screening factor is essentially a dose coefficient having units of total EDE per unit of activity $(\mathrm{Sv} / \mathrm{Bq}$ or rem/Ci). These factors incorporate radionuclide fate and transport processes and an assumed exposure scenario to calculate the annual total EDE to a hypothetical receptor per unit of activity in the radionuclide inventory. The screening factors applicable to groundwater exposure consider leaching and subsequent dilution of radionuclides in groundwater from a generic waste site. Factors are calculated for delay times of $0,2,10$, 30,100 , and 1,000 years. During the delay time, radionuclide inventories are only depleted by radioactive decay. The maximum of the six values is then reported in the screening factor tables for groundwater.

This analysis essentially has the entire waste inventory susceptible to leaching over the period of 1 year into a water volume equal to the annual average per capita use of groundwater in rural regions of the United States (i.e., 91,000 L). The receptor is then assumed to drink $800 \mathrm{~L}$ of this contaminated water over the period of a year and their dose is computed for that intake. The screening factor for groundwater is given by (NCRP 1996):

$S F=\lambda_{L} A_{o} \frac{U_{D W}}{V} \sum_{i=0}^{N} X_{i} D C F_{\text {ing }, i}$

where

$$
\begin{aligned}
& S F=\text { groundwater screening factor }(\mathrm{Sv} / \mathrm{Bq}) \\
& \lambda_{L}=\text { leach rate constant (year-1) } \\
& A_{o}=\text { initial activity }(\mathrm{Bq}) \\
& U_{D W}=\text { consumption of drinking water (assumed to be } 800 \mathrm{~L} / \text { year) } \\
& V \quad=\text { dilution volume (assumed to be } 91,000 \mathrm{~L}) \\
& X_{i}=\text { annual average fraction of the original parent activity for decay chain member } i \\
& D C F_{\text {ing }} \quad=\text { ingestion dose coefficient }(\mathrm{Sv} / \mathrm{Bq}) \\
& N \quad=\text { number of progeny in the decay chain. }
\end{aligned}
$$

Assuming there is $100 \%$ containment of the waste during delay time and the release of radioactivity is averaged over the first year of release following the delay time, the fraction of the original parent activity leached to the dilution volume over a year for the parent $\left(X_{0}\right)$ is given by:

$X_{0}=\frac{\left(1-e^{-\left(\lambda+\lambda_{0}^{r}\right) T \text { avg }}\right) e^{-\lambda_{0} T_{d e l}}}{T_{\text {avg }}\left(\lambda_{L}+\lambda_{0}^{r}\right)}$

where 
$\lambda_{o}^{r}=$ radioactive decay rate constant for parent $(1 /$ year $)$

$T_{\text {avg }}=$ averaging time $(1$ year $)$

$T_{\text {del }}=$ delay time (years).

A typographical error in Equation 4 was noted in the NCRP text. The fraction of progeny activity relative to the parent that is leached to the dilution volume is given by:

$X_{i}=\frac{1}{T_{a v g}}\left(\prod_{j=1}^{K} \lambda_{j}^{r} f_{j}\right) \sum_{h=0}^{N} \frac{\left(1-e^{-\lambda_{h}^{r} T_{a v g}}\right) e^{\lambda_{h}^{r} T_{d e l}}}{\lambda_{h}^{r} \prod_{\substack{k \\ p \neq 0 \\ p \neq h}}\left(\lambda_{p}^{r}+\lambda_{h}^{r}\right)}$

where

$f_{j} \quad=\quad$ fraction of parent decaying to jth progeny

$\lambda_{h}^{r} \quad=$ radioactive decay rate constant for jth progeny parent (1/year).

The leach rate constant $\left(\lambda_{\mathrm{L}}\right)$ is taken from a formulation described in Baes and Sharp (1983) and used in the models RESRAD (Yu et al. 2001), MEPAS (Whelan et al. 1996), and GWSCREEN (Rood 2003). The leach rate constant is given by:

$\lambda_{L}=\frac{I}{H \theta\left(I+\frac{K_{d} \rho}{\theta}\right)}$

where

$$
\begin{aligned}
& I=\text { assumed infiltration rate }(18 \mathrm{~cm} / \text { year }) \\
& H=\text { assumed waste thickness }(0.5 \mathrm{~m}) \\
& \rho=\text { bulk density }\left(\mathrm{cm}^{3} / \mathrm{g}\right) \\
& K_{d}=\text { sorption coefficient }\left(\mathrm{cm}^{3} / \mathrm{g}\right) \\
& \theta=\text { moisture content }\left(0.3 \mathrm{~m}^{3} / \mathrm{m}^{3}\right) .
\end{aligned}
$$

Values for the sorption coefficients used in the NCRP screening were taken from Kennedy and Strenge (1992). The assumed infiltration rate represents the upper-bound infiltration rate determined for low-level radioactive waste sites located in the southeastern United States. For comparison, the infiltration rate at INL into disturbed soils is less than $10 \mathrm{~cm} /$ year.

The assumption is made in Equation 4 that the unsaturated travel time is instantaneous. For INL, this is an extremely conservative assumption because unsaturated contaminant travel times have been estimated to take from several years to hundreds of thousands of years depending on the sorption properties of the contaminant. Under these assumptions, the NCRP groundwater screening model provides a conservative estimate of the potential dose.

Results shown in Section 5 retain radionuclides with a calculated NCRP screening dose greater than $0.4 \mathrm{mrem} / \mathrm{year}$ for further consideration. The NCRP screening dose is calculated by multiplying the radionuclide inventory by the NCRP screening dose factor. For example, the NCRP screening dose for Co-60 is

$S D=\left(1.48 \times 10^{-6} \mathrm{Ci}\right) x\left(2.442 \times 10^{-3} \frac{\mathrm{rem}}{\mathrm{Ci}}\right)=6.73 \times 10^{3} \mathrm{rem}$.

NCRP screening factors are unavailable for some radionuclides with extremely long half-lives (i.e., half-lives that are essentially a stable isotope [e.g., Nd-144, $\mathrm{T}^{1} 12=5 \times 10^{15}$ years]), and are unavailable where exposure via groundwater is limited by the physical form of the radionuclide (e.g., $\mathrm{Kr}-85)$. In these two cases, the radionuclides are screened from the inventory because ingestion dose factors are unavailable. 


\subsection{Phase III: Site-Specific Transport Screening}

This step accounts for leaching, advection, dispersion, and radioactive chain decay and ingrowth. A one-dimensional transport model is used to determine leaching from the source, transport through the vadose zone, and dilution and dispersion in the aquifer as illustrated in Figure 5. This model provides the concentrations in the aquifer and groundwater ingestion dose at a user-defined receptor location in the aquifer. Predicted aquifer concentrations are compared to federal MCLs. Radionuclides with predicted concentrations less than the MCL are removed from further consideration.

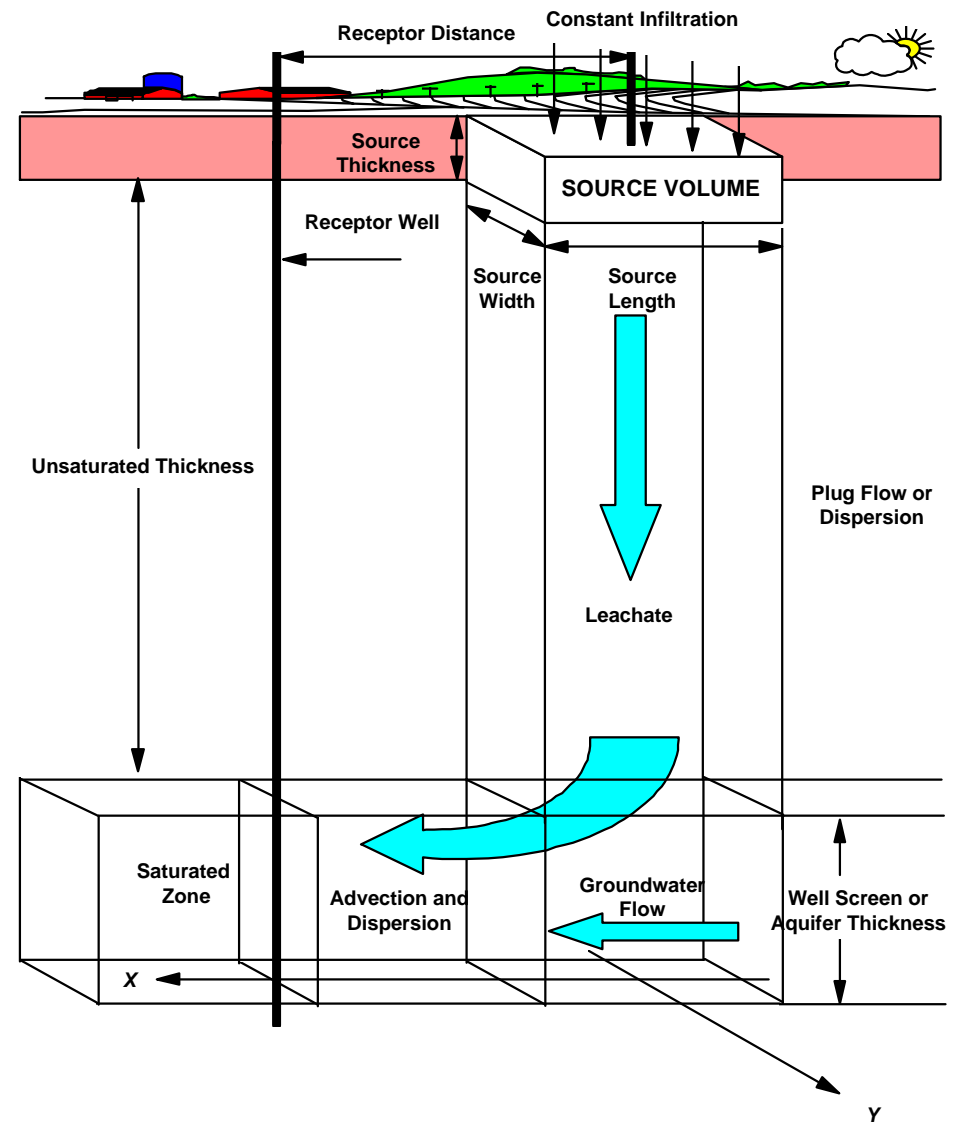

Figure 5. Conceptual model of transport implemented in this analysis.

The conceptual model of a one-dimensional unsaturated and saturated zone flow shown in Figure 5 has been implemented for Phase III using the GWSCREEN computer code (Rood 2003). GWSCREEN accounts for leaching from the source, advective transport in the unsaturated zone, sorption, and chain decay. Transport in the saturated zone is calculated with a two-dimensional or three-dimensional semianalytical solution to the advection dispersion equation in groundwater. In this application, the two-dimensional solution was used. Concentrations are vertically averaged over a well screen thickness of $15 \mathrm{~m}$ for a receptor placed at the downgradient edge of the RH-LLW disposal facility. 


\subsubsection{Flow and Transport Processes}

Flow through the source and unsaturated zone is assumed to occur only in the aqueous phase under steady-state, unidirectional (downward), and unit gradient conditions. The unsaturated zone is assumed to be a homogeneous isotropic medium of infinite extent. Solid and liquid contaminant phases are assumed to be in equilibrium and related by the linear distribution coefficient $\left(\mathrm{K}_{\mathrm{d}}\right)$.

The mass balance equation describing transport in one-dimension given steady flow is

$\frac{\partial C}{\partial t}+\frac{U_{u}}{R_{d u}} \frac{\partial C}{\partial x}=\frac{D_{x}}{R_{d u}} \frac{\partial^{2} C}{\partial x^{2}}-\lambda_{d} C$

where

$C=$ concentration $\left(\mathrm{mg}\right.$ or $\left.\mathrm{Ci} / \mathrm{m}^{3}\right)$

$R_{d u}=$ retardation in the unsaturated zone

$U_{u}=$ pore velocity (flow in the positive $\mathrm{x}$ direction, $\mathrm{m} / \mathrm{year}$ )

$D_{x}=$ dispersion coefficient in the $\mathrm{x}$ direction $\left(\mathrm{m}^{2} /\right.$ year $)$

$t=$ time (year)

$x=$ distance traversed parallel to direction of flow $(\mathrm{m})$.

The saturated zone model is represented by the advection dispersion equation for contaminants in a saturated porous medium. The model contains the following assumptions and limitations:

1. The flow is uniform and unidirectional; no sources or sinks are accounted for

2. The aquifer is modeled as an isotropic, homogeneous porous medium of infinite lateral extent and finite thickness

3. Molecular diffusion is assumed to be negligible

4. Dispersion coefficients remain constant over time

5. Transport is limited to a single species that may decay or degrade as a function of time; radioactive progeny are assumed to travel at the same rate as their parent

6. Solid and liquid phases are in equilibrium and concentrations are related by the linear $\mathrm{K}_{\mathrm{d}}$.

The mass balance equation that describes contaminant transport for the stated assumptions is

$\frac{\partial C}{\partial t}+\frac{U}{R_{d}} \frac{\partial C}{\partial x}=\frac{D_{x}}{R_{d}} \frac{\partial^{2} C}{\partial x^{2}}+\frac{D_{y}}{R_{d}} \frac{\partial^{2} C}{\partial y^{2}}+\frac{D_{z}}{R_{d}} \frac{\partial^{2} C}{\partial z^{2}}-\lambda_{d} C$

where

$C=$ concentration $\left(\mathrm{mg}\right.$ or $\left.\mathrm{Ci} / \mathrm{m}^{3}\right)$

$U=$ average linear velocity or groundwater pore velocity $(\mathrm{m} / \mathrm{year})$

$D_{x}, D_{y}, D_{z}=$ dispersion coefficients in the $\mathrm{x}, \mathrm{y}$, and $\mathrm{z}$ direction $\left(\mathrm{m}^{2} /\right.$ year $)$

$R_{d}=$ retardation factor in the aquifer

$t=$ time (year)

$x=$ distance from center of area source to receptor parallel to groundwater flow (m)

$y=$ distance from center of area source to receptor perpendicular to groundwater flow $(\mathrm{m})$

$z \quad=$ distance downward from the surface of the aquifer $(\mathrm{m})$. 
The retardation factor in the aquifer is given by

$R_{d}=1+\frac{K_{d a} \rho_{a}}{\eta}$

where

$\eta=$ the effective porosity of the aquifer $\left(\mathrm{m}^{3} / \mathrm{m}^{3}\right)$

$K_{d a}=$ the distribution coefficient in the aquifer $(\mathrm{mL} / \mathrm{g})$

$\rho_{a}=$ the bulk density in the aquifer $\left(\mathrm{g} / \mathrm{cm}^{3}\right)$.

The dispersion coefficients $\left(D_{x}, D_{y}, D_{z}\right)$ are given by

$D_{x}=\alpha_{L} U \quad D_{y}=\alpha_{t} U \quad D_{z}=\alpha_{v} U$

where

$\alpha_{L} \quad=$ the longitudinal dispersivity (m)

$\alpha_{T}=$ the transverse dispersivity (m)

$\alpha_{V}=$ the vertical dispersivity $(\mathrm{m})$.

To evaluate the movement of radioactive progeny, the model makes the simplifying assumption that radioactive progeny travel at the same rate as the parent. This assumption has been shown to be conservative (Codell et al. 1982).

\subsubsection{Phase III Model Parameterization}

The fundamental process model assumes that contaminants released near land surface could be transported downward through the stratigraphic layers comprising the vadose zone and into the aquifer by infiltration from natural precipitation. Along this transport pathway, the dilute radionuclides can undergo advection, phase-partitioning, sorption, diffusion, dispersion, and radioactive chain decay and ingrowth. Once in the aquifer, similar transport and decay processes occur as contaminants move with the regional groundwater flow. The relative influences of these processes are, in part, determined by site-specific hydrogeochemistry and are, in part, contaminant specific. Advection, dispersion, and sorption are largely determined by the geostratigraphy and localized infiltration at each individual site. Transport and radioactive decay are contaminant specific, with the contaminant inventory dictated by the waste source.

In the Phase III screening approach adopted for this environmental assessment, the important parameters and characteristics are (1) representation of the release from the source zone, (2) infiltration rate, (3) relative sediment abundance, (4) texture of the sedimentary interbeds, and (5) the velocity of water in the aquifer. Conceptualization of waste distribution and performance of the source zone determines the release rate into the upper portion of the vadose zone. The infiltration rate through the source zone fixes the hydraulic conductivity to be equal to the infiltration rate under steady-state, unit-gradient conditions in the vadose zone. Total sediment thickness determines the net sorption occurring along the transport path because it is assumed that no sorption occurs in the basalts and transit time through the basalts is instantaneous. Sediment texture determines the distribution or $\mathrm{K}_{\mathrm{d}}$, bulk density, and moisture content at a given hydraulic conductivity. The moisture content, $\mathrm{K}_{\mathrm{d}}$, and bulk density determine contaminant retardation. Net aquifer concentrations are largely determined by radionuclide flux from the vadose zone compared to the influx of clean water moving with the aquifer velocity. These parameters and characteristics are discussed in the following subsections and are summarized in Table 2. 
4.3.2.1 Source Release Model. The facility design incorporates two levels of containment in the facility itself. Waste will be placed into steel liners (canisters) that will be placed into concrete vaults separated by fine-grained soils or sands. At the end of the operational period, the waste vaults will be covered with an infiltration-reducing cap. Early in the facility lifetime, the cover will limit infiltration into the waste zone, the concrete vaults will limit contact of infiltrating water with the steel containers, and the steel containers will limit water contact with the waste. Over time, the infiltration-reducing properties of the cap could degrade, as could the concrete. Additionally, the steel containers could degrade, allowing water contact with the waste forms. Over long-periods of time, the waste zone would revert to a mix of radionuclides, soil, and degraded concrete and metal.

Radionuclides will be placed into the proposed facility in different waste forms, with the waste form determining the availability of each species to be transported in the infiltrating water. Radionuclides incorporated into metals will release differentially from those adsorbed onto resins, with the most readily available coming from those on metal surfaces and those disposed of as miscellaneous debris and trash. A complete source release model would account for degradation of the cap, concrete, and steel liners. Additionally, a source release model would differentially account for surface wash, metal corrosion from the metal parts, and desorption from resins. These processes occur over time periods that would allow for natural decay of radionuclides.

The most conservative assumptions would neglect containment provided by the concrete and steel liners, desorption from resins, and corrosion of activated metals, essentially skipping the early and midlife facility phases, resulting in the final, well-mixed assemblage of radionuclides and soils. This source release model will be adopted for both candidate sites. It will be represented in GWSCREEN as a $10-\mathrm{m} \times 240$-m soil-radionuclide mixture $6 \mathrm{~m}$ deep, oriented with the long-axis perpendicular to the aquifer flow direction. Soil properties in this source region will be assumed to be equal to the site-specific properties discussed in the following subsections.

4.3.2.2 Infiltration Rate. As implied above, during the operational period, infiltration into the facility will not contact the waste emplaced in the steel liners and concrete vaults. After capping the facility, infiltration through the waste zone will be small by design. Over the long term, the infiltration is assumed to revert back to natural conditions as the cap and vault-system degrade.

Infiltration at both sites will be assumed to be $10 \mathrm{~cm} /$ year throughout the duration of the simulations. After facility closure, an infiltration-reducing engineered barrier (cover) will be placed over the facility. The cover will conform to design specifications determined by the facility performance assessment and, in keeping with similar barriers emplaced at INL, is expected to initially limit infiltration to less than $1 \mathrm{~mm} /$ year. During the next 1,000 years, the infiltration rate is expected to increase as the performance of the cover degrades, with the infiltration rate reverting back to conditions representative of INL undisturbed sediments $(1 \mathrm{~cm} /$ year $)$.

For reference, $10 \mathrm{~cm} /$ year is representative of natural infiltration through disturbed sediments across INL. The $10 \mathrm{~cm} /$ year value is the default Track 2 value (DOE-ID 1994) used for groundwater screening assessments of low-impact INL CERCLA sites. For comparison, the total average precipitation at INL is about $21 \mathrm{~cm} /$ year. Background infiltration rates outside the Subsurface Disposal Area at RWMC in undisturbed sediments are estimated to be on the order of $1.0 \mathrm{~cm} /$ year (Cecil et al. 1992) or as low as $0.1 \mathrm{~cm} /$ year based on Mattson et al. (2004). Inverse modeling using soil moisture profiles measured with neutron logging coupled with meteorological time histories was used to estimate infiltration at monitoring locations around the Subsurface Disposal Area (Martian and Magnuson 1994; Martian 1995). These inverse modeling estimates were used in combination with surface topography to assign a distribution of three infiltration rates across the Subsurface Disposal Area (Martian 1995). These three rates are $1 \mathrm{~cm} /$ year $(0.4 \mathrm{in} . /$ year), which is the same as the background infiltration rate traditionally assumed for undisturbed soil outside the Subsurface Disposal Area; $3.7 \mathrm{~cm} /$ year (1.5 in./year), representing a medium value; and $10.0 \mathrm{~cm} /$ year (4 in./year), representing infiltration through drainage ditches where water and 
snow are intentionally diverted. The spatial average infiltration used for the RWMC Remedial Investigation and Baseline Risk Assessment (DOE-ID 2006b) was $5 \mathrm{~cm} /$ year. These rates represent net infiltration, or recharge, because the influence of evapotranspiration is included in the inverse modeling (Martian 1995).

The performance period of the proposed RH-LLW facility is 1,000 years, and the vadose zone transit time ranges from 50 to 100,000 s of years. Over longer time periods, natural compaction and weathering processes would return the waste-soil source zone to undisturbed conditions; therefore, assuming $10-\mathrm{cm} /$ year infiltration representative of disturbed conditions throughout the lifetime of the facility is conservative.

Other sources of water are not expected to influence subsurface infiltration at either Candidate Site. Other sources considered include underflow from the Big Lost River and anthropogenic water. The influence of the Big Lost River is addressed in INL (2010c). Anthropogenic water discharges at the ATR Complex and at INTEC have been extensively studied (DOE-ID 2003a, DOE-ID 2005a, DOE-ID 1997b, DOE-ID 2006a). Perched water at the ATR Complex or INTEC does not extend to either of the proposed disposal facility locations.

4.3.2.3 Relative Sediment Abundance. Geostratigraphy at INL is comprised of interlayered basalts and sedimentary interbeds. The basalts very readily transmit water vertically and they have little adsorptive capacity. In contrast, sediment in the interbeds retains water and serves to retard downward migration of radionuclides. Sediment at both proposed sites contain a mixture of clays, silts, and sands, all of which hold sorptive capacity.

Primary sedimentary interbeds have been identified and extensively characterized through activities supporting CERCLA actions at the ATR Complex and at INTEC (DOE-ID 1997a; DOE-ID 1997b; DOE-ID 2006a; and Helm-Clark et al. 2005). The lateral continuity and variability in sediment thickness at INTEC was evaluated in DOE-ID (2006a) as part of the CERCLA investigation and at the ATR Complex (INL 2010b).

These primary interbeds are shown in cross-sections for proposed Sites 5 and 34 in Figures 6 and 8 . The geologic cross-section adjacent to proposed Site 5 (Figure 1) is shown in Figure 6, with its path shown in Figure 7. The mean cumulative sediment thickness for this site is approximately $20 \mathrm{~m}$ and is based on sedimentary occurrence in the closest eight wells and the geostatistical analysis in INL (2010b). Figure 8 shows a north-south cross-section through INTEC that passes just east of proposed Site 34 (Figure 9). The mean sediment thickness near Site 34 at INTEC is approximately $17 \mathrm{~m}$ (DOE-ID 2006a, DOE-ID 2010).

4.3.2.4 Sedimentary Interbed Properties. Sediment texture and hydraulic conductivity also have been characterized as part of the INTEC and ATR Complex CERCLA investigations and documented for INTEC (DOE-ID 1997b; DOE-ID 2006a; DOE-ID 2003b). Interbeds at INTEC are generally characterized as sandy silts, with percentages of clay, silt, sand, and gravel equal to $15.7,44.5$, 27.7 , and $12.1 \%$, respectively (DOE-ID 2003b). Sediment comprising the interbeds at Site 5 contains more clay content and very little gravel. Percentages of clay, silt, sand, and gravel at Site 5 are 22.9, 38.6, 37.7 , and $0.8 \%$, respectively (Doornbos et al. 1991). The hydraulic constitutive relationships documented for high-permeability sediment in DOE-ID (2006a) were adopted for the analysis of Site 34. At the $10 \mathrm{~cm} /$ year hydraulic conductivity and infiltration rate, the corresponding moisture content is 0.0979 . At Site 5 , the corresponding moisture content is 0.359 , which is consistent with silt-loams (DOE-ID 2004). For conservatism, the lowest $\mathrm{K}_{\mathrm{d}}$ value recommended by DOE-ID (1994), Jenkins (2001) and DOE-ID (2006a) was used.

4.3.2.5 Aquifer Velocity. Aquifer velocities across INL are spatially variable. The composite analysis of INL-wide groundwater CERCLA impacts resulted in a parameterized and calibrated flow 
model encompassing the INTEC and ATR Complex areas (DOE-ID 2008). The Darcy velocities downgradient of Site 34 are approximately equal to $21.9 \mathrm{~m} /$ year. The eastern region of the proposed Site 5 has a similar Darcy velocity of $21.0 \mathrm{~m} /$ year.

4.3.2.6 Other Model Parameters. Default Track 2 dispersivity values of $9 \mathrm{~m}$ (longitudinal) and $4 \mathrm{~m}$ (transverse) were applied. An aquifer porosity of 0.06 was used, which corresponds to that determined through calibration of the INL-wide groundwater model (DOE-ID 2008). No dispersivity was applied in the vadose zone. The receptor was assumed to reside at the downgradient edge of the proposed RH-LLW facility boundary.

Table 2. Input parameters used for Phase III screening calculations.

\begin{tabular}{|c|c|c|c|}
\hline $\begin{array}{l}\text { GWSCREEN } \\
\text { Variable }\end{array}$ & Parameter Description & Value & Comments \\
\hline \multicolumn{4}{|l|}{ Card 7 (Source) } \\
\hline $\mathrm{L}$ & $\begin{array}{l}\text { Source length parallel to } \\
\text { groundwater flow }\end{array}$ & $10 \mathrm{~m}$ & $\begin{array}{l}\text { Based on RH-LLW facility design. The facility is } \\
\text { assumed to be oriented east-west, which is } \\
\text { perpendicular to regional groundwater flow. }\end{array}$ \\
\hline $\mathrm{W}$ & $\begin{array}{l}\text { Source width } \\
\text { perpendicular to } \\
\text { groundwater flow }\end{array}$ & $240 \mathrm{~m}$ & $\begin{array}{l}\text { Based on RH-LLW facility design. The facility is } \\
\text { assumed to be oriented east-west, which is } \\
\text { perpendicular to regional groundwater flow. }\end{array}$ \\
\hline PERC & $\begin{array}{l}\text { Percolation rate through } \\
\text { source into vadose zone }\end{array}$ & $0.1 \mathrm{~m} /$ year & DOE-ID $(1994$, p. C-11) \\
\hline \multicolumn{4}{|c|}{ Card 8b (Source) } \\
\hline THICKS & Thickness of source & $6 \mathrm{~m}$ & Based on facility design and a two-vault stacking \\
\hline RHOS & $\begin{array}{l}\text { Bulk density of source } \\
\text { zone }\end{array}$ & $1.82 \mathrm{~g} / \mathrm{m}^{3}$ & $\begin{array}{l}\text { Based on the high-permeability alluvium (DOE-ID } \\
\text { 2006a) }\end{array}$ \\
\hline \multicolumn{4}{|c|}{ Card 8c (Source) } \\
\hline THETAS & $\begin{array}{l}\text { Moisture content of } \\
\text { source }\end{array}$ & $\begin{array}{c}0.0989 \\
\mathrm{~cm}^{3} / \mathrm{cm}^{3}\end{array}$ & $\begin{array}{l}\text { Based on } 10-\mathrm{cm} / \text { year infiltration and hydraulic } \\
\text { properties of high-permeability alluvium (DOE-ID } \\
2010 \text { ) }\end{array}$ \\
\hline \multicolumn{4}{|c|}{ Card 9 (Unsaturated Zone) } \\
\hline DEPTH & $\begin{array}{l}\text { Depth from base of } \\
\text { source to top of aquifer } \\
\text { for Site } 5\end{array}$ & $20 \mathrm{~m}$ & $\begin{array}{l}\text { Site-specific value based on geostatistical analysis } \\
\text { of nearby wells (INL 2010b) }\end{array}$ \\
\hline DEPTH & $\begin{array}{l}\text { Depth from base of } \\
\text { source to top of aquifer } \\
\text { for Site } 34\end{array}$ & $16 \mathrm{~m}$ & $\begin{array}{l}\text { Site-specific value based on interbed thickness } \\
\text { underlying the ICDF (DOE-ID 2010) }\end{array}$ \\
\hline RHOU & $\begin{array}{l}\text { Bulk density-unsaturated } \\
\text { zone for Site } 5\end{array}$ & $1.5 \mathrm{~g} / \mathrm{cm}^{3}$ & DOE-ID (1994, p. C-11) \\
\hline RHOU & $\begin{array}{l}\text { Bulk density-unsaturated } \\
\text { zone for Site } 34\end{array}$ & $1.34 \mathrm{~g} / \mathrm{cm}^{3}$ & $\begin{array}{l}\text { Site-specific value for high-permeability interbeds } \\
\text { (DOE-ID 2006a) }\end{array}$ \\
\hline AUX & $\begin{array}{l}\text { Longitudinal dispersivity } \\
\text { - unsaturated zone }\end{array}$ & $0 \mathrm{~m}$ & $\begin{array}{l}\text { Assumed plug flow through unsaturated zone for } \\
\text { both sites }\end{array}$ \\
\hline
\end{tabular}


Table 2. (continued).

\begin{tabular}{|c|c|c|c|}
\hline $\begin{array}{l}\text { GWSCREEN } \\
\text { Variable }\end{array}$ & Parameter Description & Value & Comments \\
\hline \multicolumn{4}{|c|}{ Card 9a (Unsaturated Zone) } \\
\hline THETAU & $\begin{array}{l}\text { Volumetric moisture } \\
\text { content of unsaturated } \\
\text { zone for Site } 5\end{array}$ & $\begin{array}{c}0.359 \\
\mathrm{~cm}^{3} / \mathrm{cm}^{3}\end{array}$ & $\begin{array}{l}\text { Site-specific value based on moisture characteristic } \\
\text { curves developed from data in well } \\
\text { ICPP-SCI-V-214 and } 10-\mathrm{cm} / \text { year infiltration }\end{array}$ \\
\hline THETAU & $\begin{array}{l}\text { Volumetric moisture } \\
\text { content of unsaturated } \\
\text { zone for Site } 34\end{array}$ & $\begin{array}{c}0.0979 \\
\mathrm{~cm}^{3} / \mathrm{cm}^{3}\end{array}$ & $\begin{array}{l}\text { Site-specific value for high permeability interbeds } \\
\text { (DOE-ID 2010) and 10-cm/year infiltration }\end{array}$ \\
\hline \multicolumn{4}{|c|}{ Card 10 (Aquifer) } \\
\hline $\mathrm{AX}$ & Longitudinal dispersivity & $9 \mathrm{~m}$ & DOE-ID (1994, p. C-11) \\
\hline AY & Transverse dispersivity & $4 \mathrm{~m}$ & DOE-ID $(1994$, p. C-11) \\
\hline $\mathrm{AZ}$ & Vertical dispersivity & NA & $\begin{array}{l}\text { Assumed two-dimensional, vertically averaged } \\
\text { model per Track } 2 \text { guidance; radionuclides are } \\
\text { mixed vertically in an aquifer that is as thick as the } \\
\text { well screen (DOE-ID 1994, p. C-11). }\end{array}$ \\
\hline $\mathrm{Z}$ & Well screen thickness & $15 \mathrm{~m}$ & DOE-ID $(1994$, p. C-11) \\
\hline \multicolumn{4}{|c|}{ Card 11 (Aquifer) } \\
\hline $\mathrm{U}$ & $\begin{array}{l}\text { Darcy velocity in aquifer } \\
\text { for Site } 5\end{array}$ & $21.0 \mathrm{~m} /$ year & Site-specific value (DOE-ID 2008) \\
\hline $\mathrm{U}$ & $\begin{array}{l}\text { Darcy velocity in aquifer } \\
\text { for Site } 34\end{array}$ & $21.9 \mathrm{~m} /$ year & Site-specific value (DOE-ID 2010) \\
\hline PHI & Porosity of aquifer & $0.06 \mathrm{~cm}^{3} / \mathrm{cm}^{3}$ & Porosity of fractured basalt \\
\hline RHOA & Bulk density of aquifer & $1.9 \mathrm{~g} / \mathrm{cm}^{3}$ & DOE-ID $(1994$, p. C-11) \\
\hline \multicolumn{4}{|c|}{ Card $12 b$ (Output) } \\
\hline XREC(I) & $\begin{array}{l}\text { Receptor distance } \\
\text { parallel to groundwater } \\
\text { flow (measured from } \\
\text { center of source) }\end{array}$ & $5 \mathrm{~m}$ & $\begin{array}{l}\text { One-half the length of source (AL/2), which is } \\
\text { immediately downgradient of the facility }\end{array}$ \\
\hline YREC(I) & $\begin{array}{l}\text { Receptor distance } \\
\text { perpendicular to } \\
\text { groundwater flow } \\
\text { (measured from center of } \\
\text { source) }\end{array}$ & $0 \mathrm{~m}$ & $\begin{array}{l}\text { Receptor located along flow path through center of } \\
\text { source }\end{array}$ \\
\hline \multicolumn{4}{|l|}{ Card 5 (Dose) } \\
\hline WI & $\begin{array}{l}\text { Water intake rate for } \\
\text { receptor }\end{array}$ & $2 \mathrm{~L} / \mathrm{d}$ & Track 2 default (DOE-ID 1994, p. C-8) \\
\hline $\mathrm{EF}$ & Exposure frequency & $365 \mathrm{~d} /$ year & Assume continuous exposure \\
\hline $\mathrm{ED}$ & Exposure duration & 1 year & $\begin{array}{l}\text { If exposure duration is set at } 1 \text { year or less, then } \\
\text { GWSCREEN will use the maximum dose for } \\
\text { calculating results }\end{array}$ \\
\hline
\end{tabular}




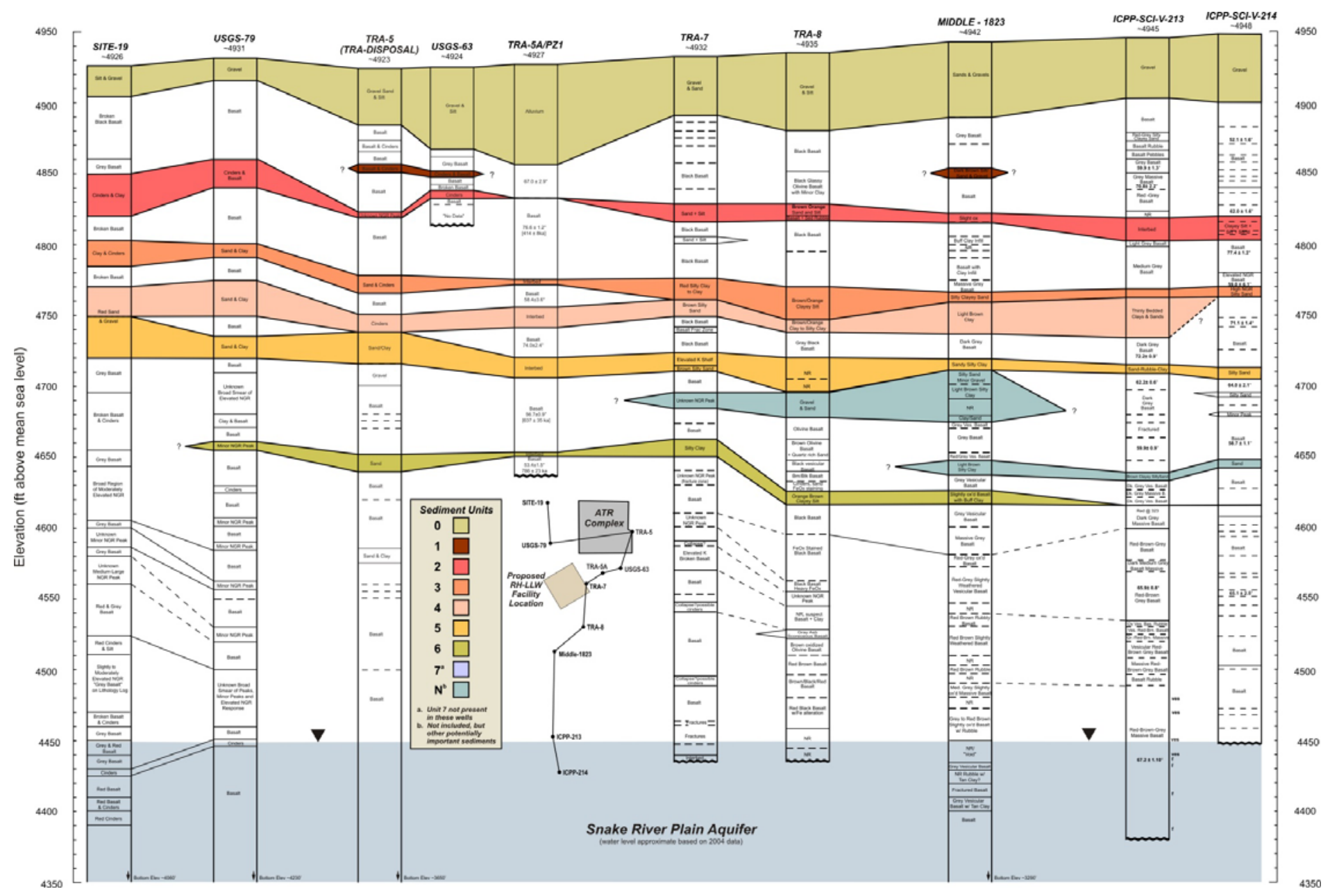

Figure 6. Geologic cross-section showing sedimentary interbed elevations and thicknesses near Site 5 southeast of the Advanced Test Reactor Complex (from INL 2010b). 


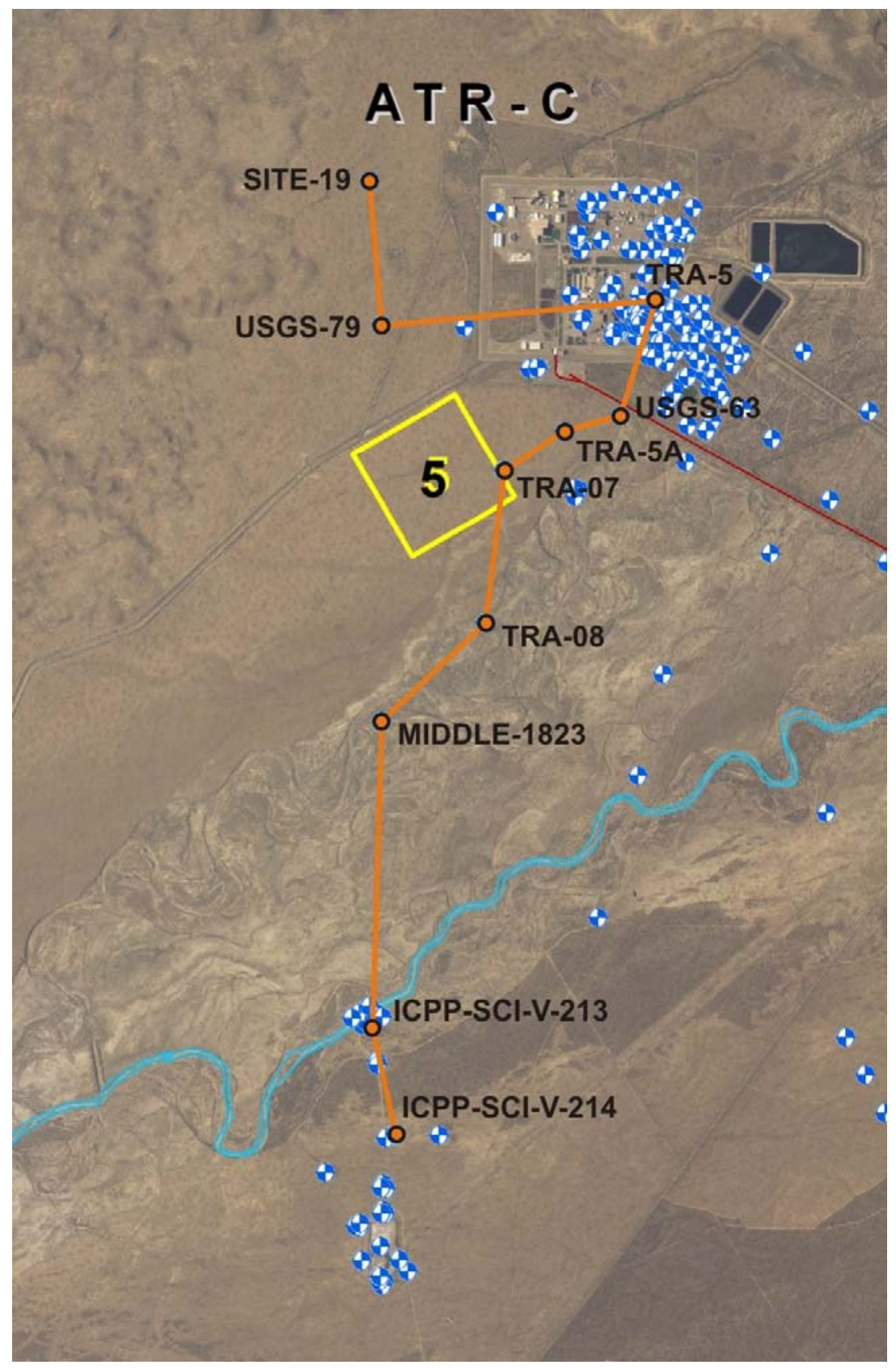

Figure 7. Location of the geologic cross-section near Site 5 shown in Figure 6. 

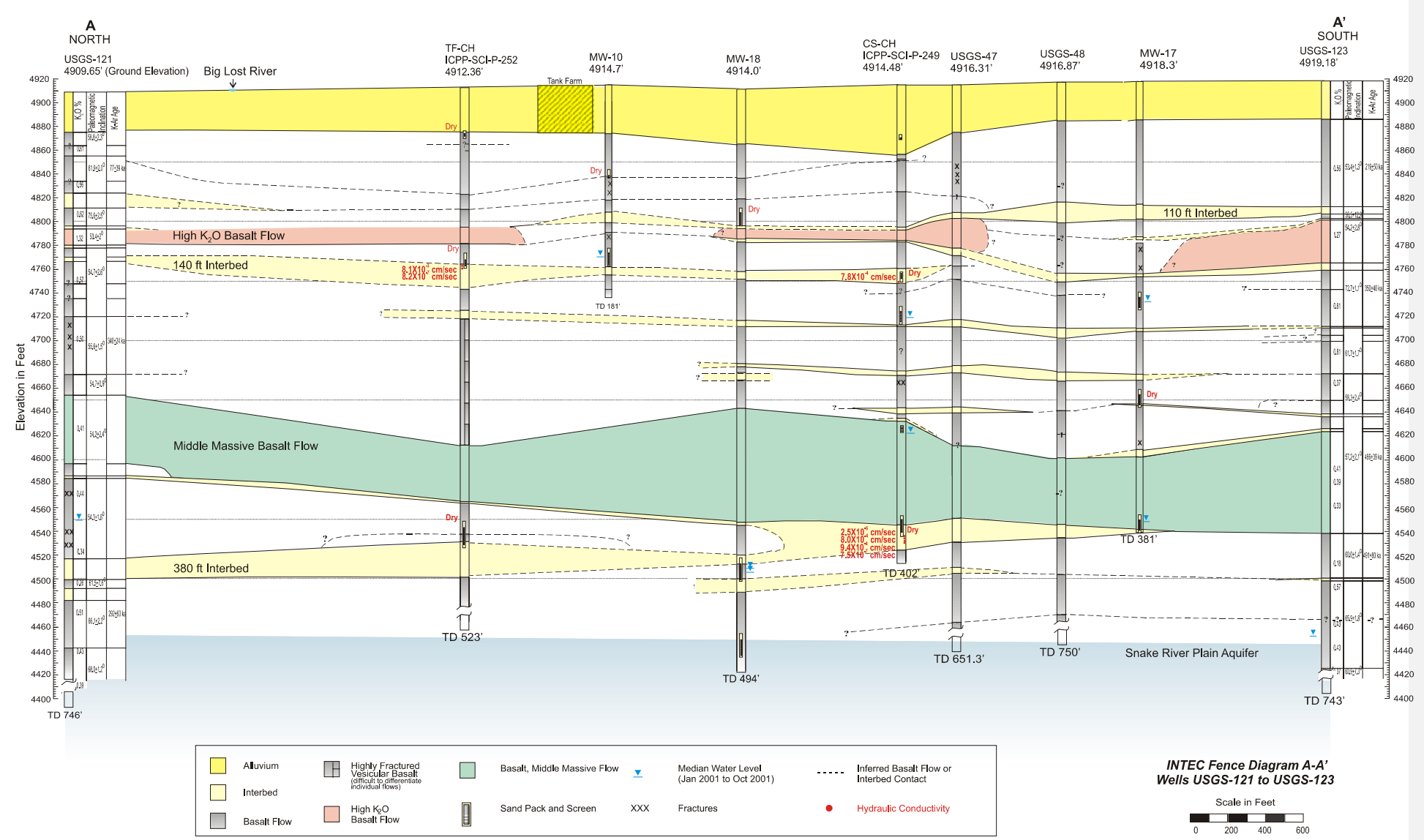

Figure 8. North-south geologic cross-section (A-A') at the Idaho Nuclear Technology and Engineering Center near Site 34 (from DOE-ID 2010). 


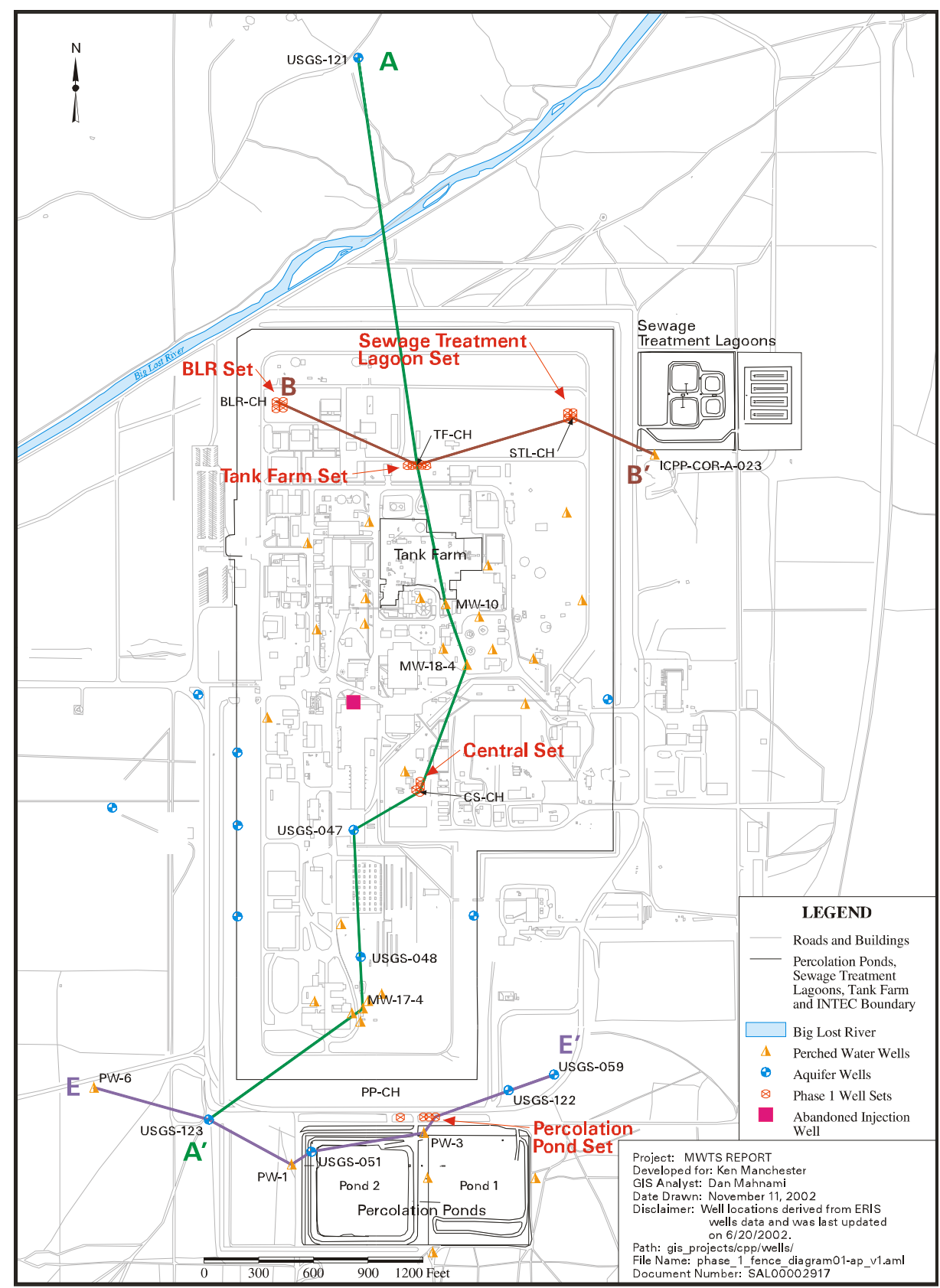

Figure 9. Location of the north-south geologic cross-section (A-A') at the Idaho Nuclear Technology and Engineering Center shown in Figure 8 (from DOE-ID 2010). 


\subsection{Phase IV: Detailed Source Release with Site-Specific Transport}

The primary differences between Phase III and Phase IV are that Phase IV includes waste-formspecific release mechanisms and rates, the functionality of the engineered barrier as it relates to reducing infiltration, site-specific $\mathrm{K}_{d} \mathrm{~s}$ in the alluvial base layer and sedimentary interbeds, and the inclusion of vadose zone and vertical aquifer dispersion. The relative sedimentary interbed abundance and other textural properties remain the same, as does aquifer velocity.

For Phase IV, the conceptual model of one-dimensional unsaturated and saturated zone has been implemented using the mixing cell model (MCM; Rood 2005). MCM allows detailed representation of surface wash from contaminated debris, dissolution or corrosion of activated metals accompanied by the release of radionuclides, and desorption of radionuclides from resins. Increasing the realism of releases from the waste zone requires parameterization of the sorption properties within and under the waste zone separately from those applied in the sedimentary interbeds and alluvium. Once released from the waste zone, it is assumed that transport occurs through the vadose zone under gravity-dominated, unit-gradient, and steady-state flow conditions. However, in addition to the assumptions and model parameters considered in Phase III, one-dimensional longitudinal dispersion is included in the vadose zone. Once in the aquifer, radionuclides are transported via advection and three-dimensional dispersion. As in Phase III, concentrations are vertically averaged over a well screen thickness of $15 \mathrm{~m}$, but the receptor is placed $100 \mathrm{~m}$ from the downgradient edge of the RH-LLW disposal facility, which is consistent with the approach required under DOE Order 435.1.

The basis for the MCM model is described in Rood (2005). The MCM model is essentially a first-order approximation to the second-order advection-dispersion equation and is similar in form to the Environmental Protection Agency assessment model SESOIL (Scott and Hetrick 1994). The conceptual model defines the unsaturated subsurface environment as a series of individual mixing cells (Figure 10). Within each mixing cell, the moisture content (fraction of the mixing cell volume composed of water) and contaminant concentration are uniform and assumed to equilibrate instantaneously in response to a change in the amount of water or contaminant entering the cell. Each mixing cell may have its own unique properties that include vertical dimensions, bulk density, hydraulic characteristics (e.g., porosity, residual moisture content, and hydraulic conductivity), and sorptive properties. Water balance within each cell is maintained by the difference between inflow and outflow. The water flux or specific discharge entering the uppermost mixing cell (q) is assumed to be the net infiltration rate past the root zone. The net infiltration rate may change with time and, in turn, affect the specific discharge through all remaining cells below it. Water movement is assumed to be downward and under unit gradient conditions within a mixing cell. Specific discharge is assumed to be less than the saturated hydraulic conductivity of any of the materials comprising the vadose zone.

The conceptual model for contaminant transport considers two processes: advection and dispersion. Advective processes ( $\mathrm{F}$ in Figure 10) move the contaminant downward while dispersive processes ( $\mathrm{D}$ in Figure 10) can move the contaminant upward or downward, depending on the concentration gradient between two adjacent cells. Dispersion results in greater spreading of the contaminant among the mixing cells. As shown later, dispersion effects can be simulated through implicit dispersion inherent in a MCM or may be simulated by including interchange between adjacent mixing cells.

Contaminant degradation is assumed to be a first-order process described by a half-life. The contaminant may degrade into one or more degradation products, each formed from the preceding product, and thereby forming a chain of degradation products such as in a radionuclide decay chain.

Contaminants entering a cell mix, sorb, decay, and are eventually removed by the downward movement of water. Contaminants sorb onto the solid matrix as described by the soil-to-water partition coefficient or $\mathrm{K}_{\mathrm{d}}$. Sorption retards the overall downward movement of contaminants. The rate of transport of the degradation products that form during vertical transport are governed by the sorptive properties of the degradation product, and not those of the originating contaminant. 


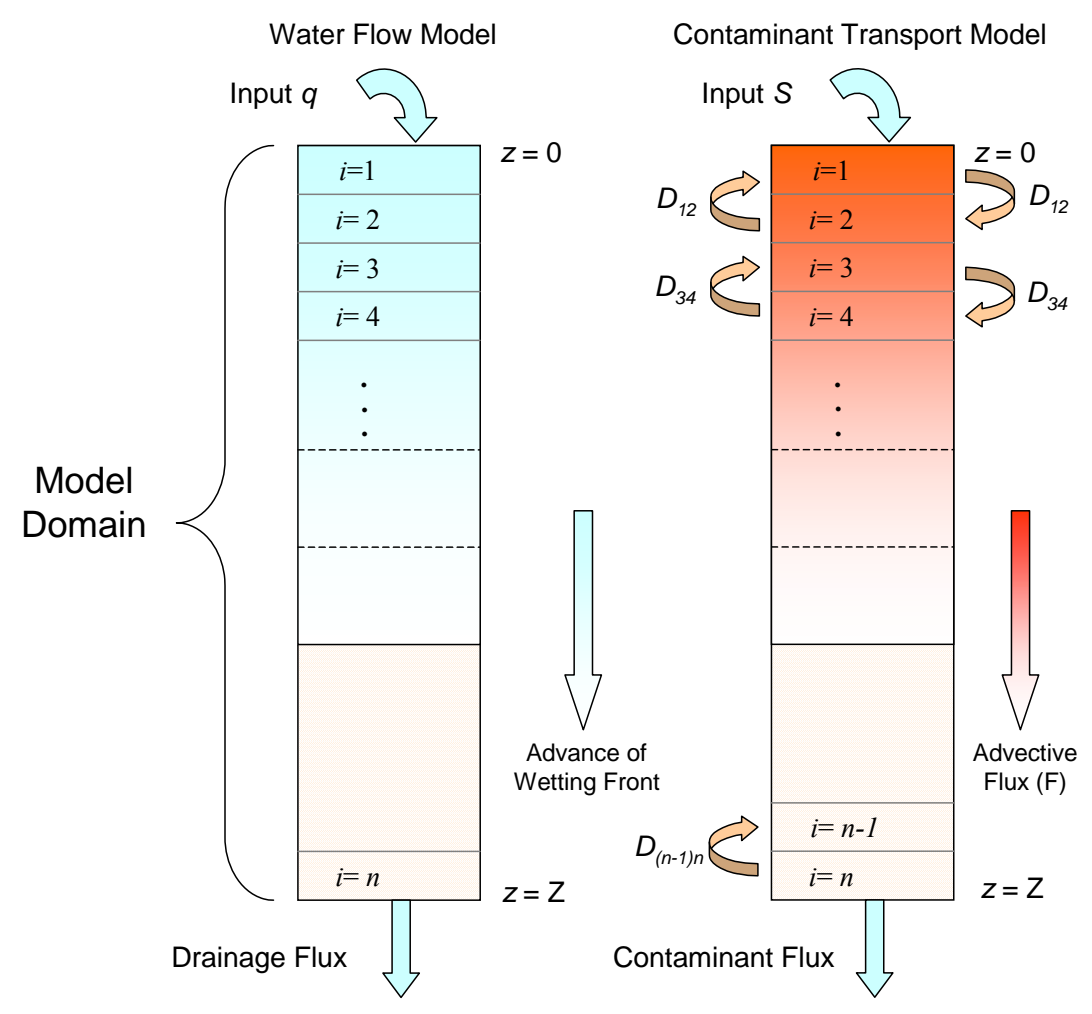

Figure 10. The mixing cell conceptual model for water flow (left) and contaminant transport (right). The model domain is discretized into $\mathrm{n}$ cells and extends to a depth of $\mathrm{z}=\mathrm{Z}$. Interchange between cells is indicated by the variable $\mathrm{Di}, \mathrm{j}$ where $\mathrm{i}$ is the index of the donor cell and $\mathrm{j}$ is the index of the receiving cell.

As formulated, contaminants may be present in one or more of the mixing cells at the start of the simulation (as done for the low-mobility radionuclides in this analysis), or alternatively, the contaminant may be placed over time through an external source (S in Figure 10) (as done for the high-mobility radionuclides in this analysis). Concentrations of contaminants in pore water are not allowed to exceed their element or compound-specific solubility limit.

\subsubsection{Flow and Transport Processes}

4.4.1.1 Mixing Cell Model Water Flow. A one-dimensional water-balance model coupled with material-specific moisture characteristic curves are used to calculate the net water flux through each MCM mixing cell, assuming unit gradient conditions exist throughout each cell. Additionally, water is assumed to be incompressible, its density remains constant, vapor-phase flow is inconsequential, and hydrostatic conditions are assumed to never exist (i.e., a net water flux of zero). The unit gradient model assumes water infiltration in the soil column is downward and driven by gravitational forces only.

Mathematically, the specific discharge (i.e., Darcy velocity or Darcy flux) through a one-dimensional, vertically aligned, unsaturated soil column is described by:

$q=-K\left(\frac{\partial H}{\partial z}+\frac{\partial \psi}{\partial z}\right)$ 
where

$q \quad=$ specific discharge $(\mathrm{L} / \mathrm{T})$

$\theta=$ volumetric moisture content $\left(\mathrm{L}^{3} / \mathrm{L}^{3}\right)$

$H \quad$ = elevation head (L)

$\psi \quad=$ suction or pressure head from capillary forces (L)

$K=$ unsaturated hydraulic conductivity of the column $(\mathrm{L} / \mathrm{T})$

$z \quad=$ distance positive downward from the top of the column (L).

Under unit gradient conditions $\frac{\partial \psi}{\partial z}=0$ and $\frac{\partial H}{\partial z}=1$. Therefore, $\mathrm{q}=\mathrm{K}$, provided $\mathrm{q}$ is less than the saturated hydraulic conductivity. That is, the amount of water discharged from a mixing cell is equal to the unsaturated hydraulic conductivity at a given volumetric moisture content. The volumetric moisture content is the fraction of the bulk media that is filled with water. When a porous media is saturated (i.e., all the pore spaces are filled with water), the volumetric moisture content is equal to the effective porosity of the media. In this model, we have assumed the effective porosity is equal to the total porosity. Unit gradient conditions are assumed to exist at all times within a mixing cell. That is, once water enters the mixing cell, it is instantaneously and uniformly distributed within the mixing cell. Capillary forces are explicitly excluded from the model by assuming unit gradient conditions exist at all times. However, as shown in Rood (2005), these forces are implicitly accounted for through model discretization. Each cell is treated as an independent unit that may receive water from a cell above it and discharge water to the cell beneath it.

The continuity equation (assuming constant water density) states that change in the water stored in a unit volume of soil must equal the difference between the flux into and out of the unit volume and is given by:

$\frac{\partial \theta}{\partial t}=-\frac{\partial q}{\partial z}$.

Combining Equations 12 and 13 with the unit gradient assumptions gives the traditional formulation for one-dimensional unsaturated flow in a porous medium known as Richard's equation:

$\frac{\partial \theta}{\partial t}=\frac{\partial}{\partial z}\left(K \frac{\partial \psi}{\partial z}-K\right)$.

The unsaturated hydraulic conductivity is a function of the moisture content and described by the moisture characteristic curve. Combining Equations 12 and 13, with the assumption of unit gradient conditions (i.e., $\frac{\partial \psi}{\partial z}=0$ ) gives

$\frac{\partial \theta}{\partial t}=-\frac{\partial}{\partial z} K(\theta)$

The term, $\partial \mathrm{K}(\theta) / \partial \mathrm{z}$ is approximated for the MCM by:

$\frac{\partial \theta_{i}}{\partial t}=\frac{\mathrm{K}_{\mathrm{i}-1}\left(\theta_{\mathrm{i}-1}\right)-\mathrm{K}_{\mathrm{i}-1}\left(\theta_{\mathrm{i}-1}\right)}{\mathrm{Z}_{\mathrm{i}}-\mathrm{Z}_{\mathrm{i}-1}}$

where $i$ is the cell index number and $z_{i}$ is the depth of cell $i$ below a datum at index $i=0, z=0$. The water storage in the $i^{\text {th }}$ mixing cell $\left(\phi_{\mathrm{i}}\right)$ is given by:

$\phi_{i}=\theta_{i} T_{i}$

where $T_{i}$ is the thickness of the $i^{t h}$ mixing cell, which is equivalent to $z_{i}-z_{i-1}$. Equation 16 is now rewritten in terms of the change in water storage with respect to time and given by: 
$\frac{d \phi_{i}}{d t} \frac{1}{T_{i}}=\frac{K_{i-1}\left(\theta_{i-1}\right)-K_{i}\left(\theta_{i}\right)}{T_{i}}$
$\frac{d \phi_{i}}{d t}=K_{i-1}\left(\theta_{i-1}\right)-K_{i}\left(\theta_{i}\right)$

For the uppermost mixing cell $(i=1), K_{i^{-} l}\left(\theta_{i^{-} l}\right)=K_{0}\left(\theta_{0}\right)=q(t)$ where $q(t)$ is the net infiltration rate as a function of time into the uppermost mixing cell. Note that volumetric flow rates are achieved by multiplying Equation 18 by the horizontal surface area of the cells.

The functional relationship between the unsaturated hydraulic conductivity and moisture content is made using established empirical relationships that relate suction head to volumetric moisture content and unsaturated hydraulic conductivity. The relationship between these three parameters is referred to hereafter as the moisture characteristic curve. For this model, the unsaturated hydraulic conductivity as a function of moisture content as described by van Genuchten (1980) was used and is given by:

$K(\theta)=K_{\text {sat }}\left(\frac{\theta-\theta_{r}}{\theta_{s}-\theta_{r}}\right)^{L}\left\{1-\left[1-\left(\frac{\theta-\theta_{r}}{\theta_{s}-\theta_{r}}\right)^{\frac{1}{m}}\right]^{m}\right\}^{2}$

and

$\frac{\theta-\theta_{r}}{\theta_{s}-\theta_{r}}=\left[\frac{1}{1+(\alpha \psi)^{n}}\right]^{m} \quad\left(\theta_{r} \leq \theta \leq \theta_{s}\right)$

where

$\theta=$ volumetric moisture content $\left(\mathrm{L}^{3} \mathrm{~L}^{-3}\right)$

$\theta_{r} \quad=$ residual moisture content $\left(\mathrm{L}^{3} \mathrm{~L}^{-3}\right)$

$\theta_{s}=$ saturated moisture content $\left(\mathrm{L}^{3} \mathrm{~L}^{-3}\right)$

$K_{\text {sat }}=$ saturated hydraulic conductivity $\left(\mathrm{L} \mathrm{T}^{-1}\right)$

$\psi \quad=\quad$ soil water matric suction pressure $(\mathrm{L})$

$\alpha=$ empirical fitting parameter $\left(\mathrm{L}-^{-1}\right)$

$n=$ empirical fitting parameter

$m=1-1 / n$

$L \quad=\quad$ Mualem fitting parameter.

The moisture characteristic equations are valid when $\mathrm{q}<$ Ksat. Hydraulic properties that consider hysteresis were not included in this formulation. The moisture content in the $i^{\text {th }}$ mixing cell is used in combination with the moisture characteristic curve to determine $\mathrm{K}_{\mathrm{i}}\left(\theta_{\mathrm{i}}\right)$, the specific discharge through the $i^{\text {th }}$ mixing cell. The value of $\mathrm{K}_{\mathrm{i}}\left(\theta_{\mathrm{i}}\right)$ as a function of time is then passed to the transport model.

4.4.1.2 Mixing Cell Model Transport. The model for solute transport explicitly treats advective processes and implicitly or explicitly treats dispersive processes. The model is based on the one-dimensional partial differential equation for mass transport in a variably saturated porous medium. The general transport equation for a single contaminant with first-order decay is given by (Codell et al. 1983):

$R_{D} A \theta \frac{\partial C}{\partial t}=A \frac{\partial}{\partial z}\left(\theta D \frac{\partial C}{\partial z}\right)-A \frac{\partial q C}{\partial z}-\left(R_{D} \theta \lambda+R_{D} \frac{\partial \theta}{\partial t}\right) A C$

where

$A=$ across sectional area perpendicular to flow $\left(\mathrm{L}^{2}\right)$ 


$$
\begin{aligned}
& C=\text { concentration }\left(\mathrm{M} / \mathrm{L}^{3}\right) \\
& R_{D}=\text { retardation } \\
& q \quad=\text { specific discharge or Darcy velocity }(\mathrm{L} / \mathrm{T}) \\
& D=\text { dispersion coefficient }\left(\mathrm{L}^{2} / \mathrm{T}\right) \\
& t \quad=\text { time }(\mathrm{T}) \\
& \lambda \quad=\text { first-order decay constant }(1 / \mathrm{T}) \\
& z \quad=\text { distance traversed parallel to direction of flow }(\mathrm{L}) .
\end{aligned}
$$

The mixing cell approximation is written in terms of the mass balance around fully mixed volume elements. Assuming unidirectional flow in the positive $z$ direction, the MCM formulation for interior cells (i.e., $\mathrm{i} \neq 1$ and $\mathrm{i} \neq \mathrm{n}$ where $\mathrm{n}$ is the number of cells) of equal thickness, $T$ is given by:

$$
T_{i} R_{D} A \theta_{i} \frac{d C_{i}}{d t}=A \sum_{k} \frac{D_{i k}}{T_{i k}}\left(\theta_{k} C_{k}-\theta_{i} C_{i}\right)+A\left(q_{i-1} C_{i-1}\right)-A\left(q_{i} C_{i}\right)-T_{i} A R_{D} \theta_{i} \lambda C_{i}+S_{i}
$$

where $i$ is the cell index, $k$ is the index for cells adjacent cell $i$ (i.e., $i-1$ and $i+1$ ), $D_{i k}$ is the dispersion coefficient between cell $i$ and $k\left(\mathrm{~L}^{2} \mathrm{~T}^{-1}\right), T_{i k}$ is the distance separating the center of cell $i$ and $k(\mathrm{~L})$, and $S_{i}$ is an external source to cell $i\left(\mathrm{M} \mathrm{T}^{-1}\right)$. The first term in Equation 22 represents dispersion, the second and third terms represent advection, and the last term represents decay. The variables, $\theta$ and $q$, can be time-variable or constant depending on whether transient infiltration or steady-state flow is considered.

The term, $R_{D} \partial \theta / \partial t$ in Equation 21, enforces continuity between the moisture content and solute concentration. This term is zero under steady-state flow conditions. Continuity between the two quantities $(\theta$ and $C$ ) under transient flow conditions is achieved by determining the time-dependent moisture content at each time step. Moisture content as a function of time is calculated in the water flow portion of the code. The concentration in each cell at a given time-step is adjusted for the moisture content by:

$C_{i}^{m}=\frac{Q_{i}^{m}}{Q_{i}^{m} A T\left[1+\frac{K_{d_{i} \rho_{i}}}{\theta_{i}^{m}}\right]}$

where

$$
\begin{aligned}
C_{i}^{m} & =\text { contaminant pore water concentration in cell } i \text { at time-step } \mathrm{m}\left(\mathrm{M} \mathrm{L}^{-3}\right) \\
Q_{i}^{m} & =\text { mass of contaminant in cell } i \text { at time-step } \mathrm{m}(\mathrm{M}) \\
K_{d i} & =\text { equilibrium partition coefficient for mixing cell } i\left(\mathrm{~L}^{3} \mathrm{M}^{-1}\right) \\
\rho_{\mathrm{i}} & =\text { bulk density of mixing cell } i\left(\mathrm{M} \mathrm{L}^{-3}\right) \\
\theta_{i}^{m} & =\text { the moisture content in mixing cell } i \text { at time-step } \mathrm{m}\left(\mathrm{M} \mathrm{L}^{-3}\right) .
\end{aligned}
$$

The term, $1+K_{d i} \rho_{i} / \theta_{i}$ is the retardation coefficient and is unity for a $K_{d}$ of zero. Darcy fluxes in each cell and at each time step are calculated using the time-dependent value of $\theta$ and the material-specific moisture characteristic curve. If $C_{i}$, as given by Equation 23, exceeds the solubility limit, then $C_{i}=C_{S l}$ where $C_{S l}$ is the solubility limit of the contaminant. The solubility adjustment does not affect the total mass of contaminant in the cell. The left-hand side of Equation 22 and the decay terms can now be rewritten in terms of the state variable (contaminant mass) by substituting the right hand side of Equation 23 for $C$ :

$$
\frac{d Q_{i}}{d t}=A \frac{\sum_{k} D_{i k}}{T_{i k}}\left(\theta_{k} C_{k}-\theta_{i} C_{i}\right)+A\left(q_{i-1} C_{i-1}\right)-A\left(q_{i} C_{i}\right)-\lambda Q_{i}+S_{i}
$$


where $Q_{i}$ is the contaminant mass in the cell $i$. Equation 24 is valid for all nonboundary cells. Imposing the following boundary conditions:

$D \frac{d C}{d z}=0 \quad$ at $\quad z=0 \quad$ and $\quad z=Z$

gives the mass balance equations for the first $(i=1)$ and last $(i=n)$ cell in the system

$\begin{array}{ll}\frac{d Q_{1}}{d t}=A \frac{D_{12}}{T_{12}}\left(\theta_{2} C_{2}-\theta_{1} C_{1}\right)+A\left(q_{1} C_{1}\right)-\lambda Q_{1}+S_{1} & \text { for } i=1 \\ \frac{d Q_{n}}{d t}=A \frac{D_{n-1, n}}{T_{1 n-1, n}}\left(\theta_{n-1} C_{n-1}-\theta_{n} C_{n}\right)+A\left(q_{n} C_{n}\right)-A\left(q_{n-1} C_{n-1}\right)-\lambda Q_{n}+S_{n} & \text { for } i=n\end{array}$.

Implementation of Equation 24 in the MCM code is performed differently than what is presented in Rood (2005). A simple procedure is used where each cell is treated as an independent unit and advective and dispersive rate constants are defined. Sources are only considered for the first cell. The advective $(\kappa)$ and dispersion $(\delta)$ rate constants are defined as follows:

$\kappa_{i}=\frac{q}{T_{i} \theta_{\mathrm{i}} \mathrm{R}_{\mathrm{D}_{\mathrm{i}}}} \quad$ and $\quad \delta_{i}=\frac{D_{i}}{T_{i}^{2}}$.

The advective rate constant is equivalent to the leach rate constant as described in Baes and Sharp (1983). An optional rate constant (designated $k x$ ) also is introduced into the governing equations that describes the transfer from cell $i$ to cell $i+1$. This rate constant is provided by the user and is calculated external to the code. Assigning rate constants to the advection, dispersive, and optional transfer processes, and expanding the summation term results in the following equation for interior cells:

$\begin{aligned} \frac{d Q_{i}}{d t}=A[ & \left.\delta_{i-1} C_{i-1} \theta_{i-1} T_{i-1}+\delta_{i+1} C_{i+1} \theta_{i+1} T_{i+1}-2 \delta_{i} C_{i} \theta_{i} T_{i}\right] \\ & +\left(k x_{i-1}+\kappa_{i-1}\right) Q_{i-1}-\left(k x_{i}+\kappa_{i}\right) Q_{i}-\lambda Q_{i}\end{aligned}$

and

$\frac{d Q_{1}}{d t}=A\left[\delta_{2} C_{2} \theta_{2} T_{2}-\delta_{1} C_{1} \theta_{1} T_{1}\right]-\left(k x_{1}+\kappa_{1}\right) Q_{1}-\lambda Q_{1}+S_{1}$

for $i=1$

$\frac{d Q_{n}}{d t}=A\left[\delta_{n-1} C_{n-1} \theta_{n-1} T_{n-1}-\delta_{n} C_{n} \theta_{n} T_{n}\right]+\left(k x_{n-1}+\kappa_{n-1}\right) Q_{n-1}-\left(k x_{n}+\kappa_{n}\right) Q_{n}-\lambda Q_{n} \quad$ for $i=n$

for the boundary cells. Equation 28 can now be expanded to include the transport of multiple decay products

$$
\begin{aligned}
\frac{d Q_{i, j}}{d t}= & A\left[\delta_{i-1, j} C_{i-1, j} \theta_{i-1} T_{i-1}+\delta_{i+1, j} C_{i+1, j} \theta_{i+1} T_{i+1}-2 \delta_{i, j} C_{i, j} \theta_{i} T_{i}\right] \\
& +\left(k x_{i-1, j}+\kappa_{i-1, j}\right) Q_{i-1, j}-\left(k x_{i, j}+\kappa_{i, j}\right) Q_{i, j}-\lambda_{j} Q_{i, j}+B R_{j} \lambda_{j-1} Q_{i, j-1}
\end{aligned}
$$

where, $j$ is the index for the decay chain member, $B R_{j}$ is the fraction of decay product $j-1$ that decays to product $j$, and $k x_{i j}$ is the optional rate constant describing transfer from cell $i$ to cell $i+1$ for contaminant $j$. For the originating contaminant in a series of degradation products, the term, $B R_{j} \lambda_{j-l} Q_{i, j-l}$ is omitted from Equation 30. The decay rate constant is given by Equation 31:

$\lambda_{j}=\frac{\ln (2)}{t_{1 / 2}}$

where $t_{1 / 2}$ is the half-life of contaminant $j$. Equation 30 describes the MCM with interchange. Equation 30 also gives the MCM without interchange, except the dispersive terms are omitted (i.e., $\delta=0$ ). The MCM without interchange is useful because relatively simple analytical solutions exist for the equations describing the system. These solutions are useful for simple conceptual models and model verification exercises. 
The overall objective of the model is to provide a solute flux to the aquifer. The solute flux to the aquifer for degradation product $j$ at $z=Z(i=n)$ for the stated boundary conditions is given by:

$F_{j}=A\left(q_{n} C_{n, j}\right)=\frac{q_{n} Q_{n, j}}{\theta_{n} T_{n} R_{D_{n, j}}}$

where $F_{j}$ is the solute flux to the aquifer from cell $n$ for decay product $j$.

4.4.1.3 Mixing Cell Model Discretization and Solute Dispersion. The dispersive behavior of the MCM is similar to that of the advection dispersion equation and is related to the physical dispersion of the system (Zvirin and Shinnar 1976; Van Ommen 1985; Appelo and Willemsen 1987; Shanahan and Harleman 1984). Shanahan and Harleman (1984) use the term implicit dispersion to describe the dispersion that is inherent in the formulation of mass transport around fully mixed volume elements (cells) and described in terms of ordinary differential equations. The dimensionless Peclet number characterizes dispersion and is given by:

$P e=\frac{Z q}{D \theta}$

where $P e$ is the Peclet number, $Z$ is the length of the vadose zone $(L)$, and $D$ is the dispersion coefficient $\left(L^{2} T^{-1}\right)$. The dispersion coefficient is given by:

$D=\frac{\alpha_{L} q}{\theta}+D_{m}$

where $D_{m}$ is the effective molecular diffusion coefficient, and $\alpha_{L}$ is the longitudinal dispersivity.

Molecular diffusion may be important for systems with extremely low specific discharge. Equation 33 is referred to here as the scale-length Peclet number because it is the ratio of advection to dispersion for the entire system. If molecular diffusion is neglected, Equation 33 reduces to $P e=Z / \alpha_{L}$.

Levenspiel and Bischoff (1963) established a relationship between the number of equal thickness mixing cells and the scale-length Peclet number for the mixing cell-model without interchange. They concluded that the number of mixing cells is approximately related to the Peclet number as given by:

$\frac{1}{N}=\frac{2}{P e^{2}}\left(P e-1+e^{P e}\right)$

which can be approximated by Shanahan and Harleman (1984)

$N=\frac{P e+1}{2}$

or as $n$ becomes large

$N \cong \frac{P e}{2}$.

Zvirin and Shinnar (1976) as reported in Shanahan and Harleman (1984) defined the relationship between an equivalent Peclet number $(\mathrm{Pe})$ and $n$ for the MCM with interchange as

$P e=\frac{2 N}{1+2 \beta}$

where $\beta$ is the ratio of the exchange flow to through-flow and all cells are of equal size. The influence of cell interchange is to decrease the Peclet number (increase dispersion) by the factor $1+2 \beta$. Shanahan and Harleman (1984) define exchange flow as $D A / T$ and through-flow as $A q / \theta$, where $T$ is the distance separating adjacent mixing cells. If molecular diffusion is neglected, $\beta$ can be written in terms of the local dispersivity 
$\beta=\frac{D A}{A q / \theta T}=\frac{\alpha_{L^{*}} q \theta}{T q \theta}=\frac{\alpha_{L^{*}}}{T}$.

The term $\beta$ is essentially the inverse of the local (or grid) Peclet number. The term $\alpha_{L^{*}}$ represents the equivalent local dispersivity accounting for implicit dispersion. If the dispersivity of the overall system is $\alpha_{L}$, then the equivalent local dispersivity can be derived from Equations 33, 38, and 39:

$\alpha_{L^{*}}=\left[\frac{2 N \alpha_{L}}{Z}-1\right] \frac{T}{2}$.

It can be shown that as $n \rightarrow \infty, \alpha_{\mathrm{L}^{*}} \rightarrow \alpha_{\mathrm{L}}$. If $\alpha_{\mathrm{L}^{*}}$ is negative, then implicit dispersion is greater than the dispersion defined by $\alpha_{\mathrm{L}}$ and additional cells must be added. For the case where molecular diffusion is not negligible, an equivalent local dispersion coefficient $\left(D^{*}\right)$ is calculated for each cell and given by Equation 41:

$D^{*}=\left[\frac{2 D_{i}}{q_{i} / \theta_{i}}-1\right] \frac{T q_{i} / \theta_{i}}{2}$.

MCM calculates the movement of each radioactive progeny separately according to the progeny's element-specific $\mathrm{K}_{\mathrm{d}}$ (see Equation 30).

\subsubsection{Phase IV Model Parameterization}

In order to parameterize MCM, including the processes ongoing in the vault system, release mechanisms and rates from the initial waste form were first incorporated. The next level of complexity is introduced by the geochemical environment of the cement-steel-container system. Fresh cement increases the $\mathrm{pH}$ relative to natural infiltration water, creating a local geochemical environment that dictates radionuclide-specific $\mathrm{K}_{\mathrm{d}}$ values for cement-sand mixes. The geochemistry of the vault system also impacts the alluvial base layer underlying the vault system, altering the sorption behavior of alluvial materials. It is assumed that the near-field geochemical environment will revert back to natural conditions as infiltrating water not passing through the facility mixes with waters transported through the vault system. This assumption is conservative because it results in the use of lower $\mathrm{K}_{\mathrm{d}}$ values in the sedimentary interbeds than would be used if the higher $\mathrm{pH}$ environment were assumed to persist to depth.

The discretization used to represent the vault system, alluvial base layer, and basalt-sediment sequence at Site 5 is shown in Figure 11. At Site 5, the alluvial base layer is represented by $5 \mathrm{~m}$ of alluvial material as determined by the total alluvial thickness south of the ATR Complex (INL 2010b). The total sediment thickness is $20.1 \mathrm{~m}$ and depth to the aquifer is approximately $140 \mathrm{~m}$. Surficial sediment near Site 34 is represented by the values determined for the nearby ICDF facility and are thinner as represented in Figure 12 (where $2 \mathrm{~m}$ of alluvial base layer are represented). The total sedimentary interbed thickness shown in Figure 12 for Site 34 is $16.8 \mathrm{~m}$. Depth to the aquifer at INTEC is roughly equal to that at the ATR Complex. At both sites, the vault system (waste zone) is represented by $6 \mathrm{~m}$ of porous media.

4.4.2.1 Release Mechanisms and Release Rates. As the containers fail, the radionuclides are assumed to be released from their original waste form over time by either surface wash or dissolution. Surface wash generally leads to the most conservative releases because releases are assumed to occur instantaneously as water contacts the waste. This allows the entire inventory of radionuclides to be exposed to infiltrating water. The surface wash model applies a partition coefficient to determine the rate of release by maintaining the radionuclide concentration in water in proportion to $\mathrm{K}_{\mathrm{d}}$. The solid fraction considered to reside in the vault system is comprised of cement and sand. This mechanism is assumed for the debris and resin waste forms. 


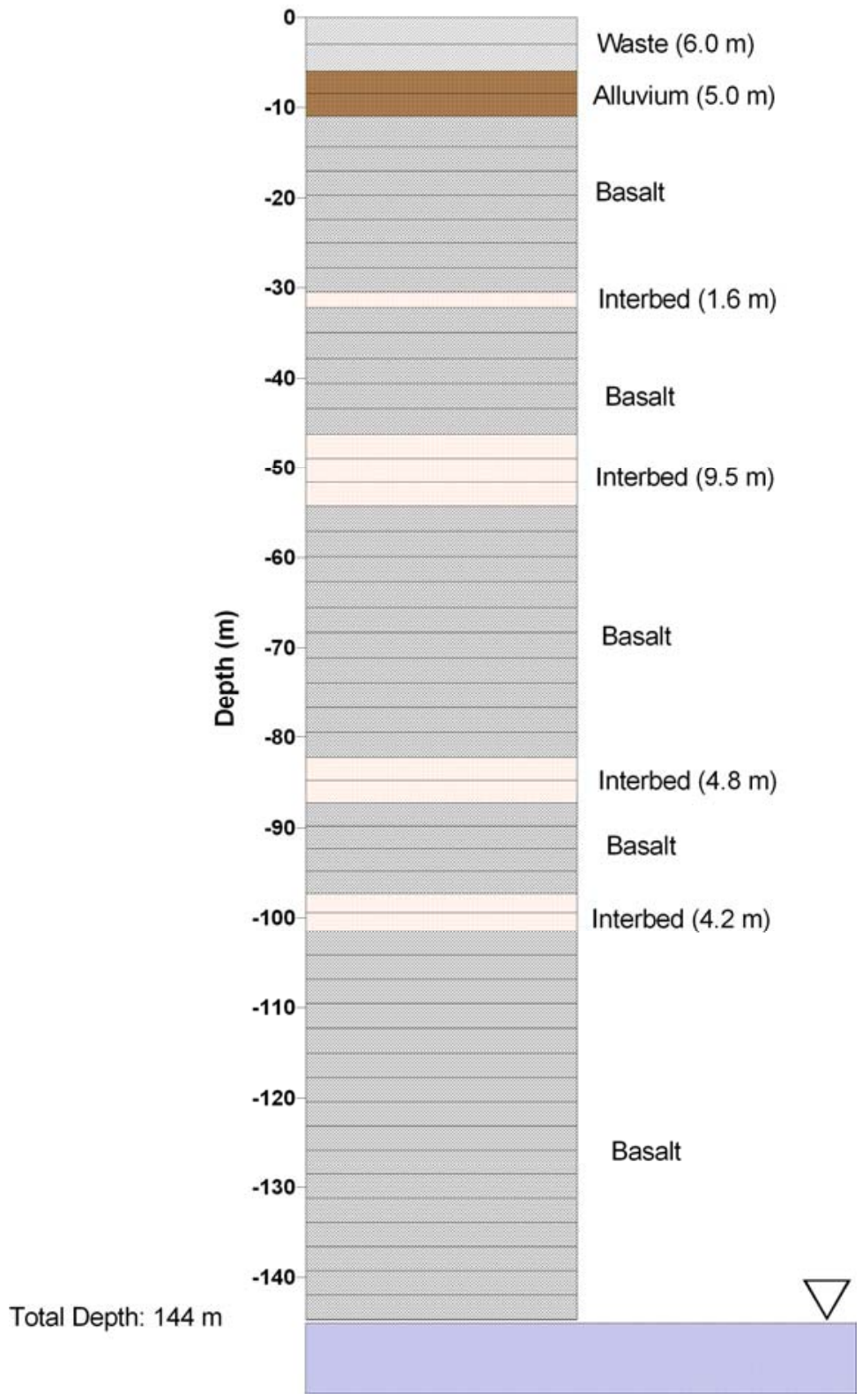

Figure 11. Discretization of the cement-sand-vault system, alluvial base layer, basalt, and sedimentary interbeds used to represent the subsurface at Site 5 (near ATR Complex). 


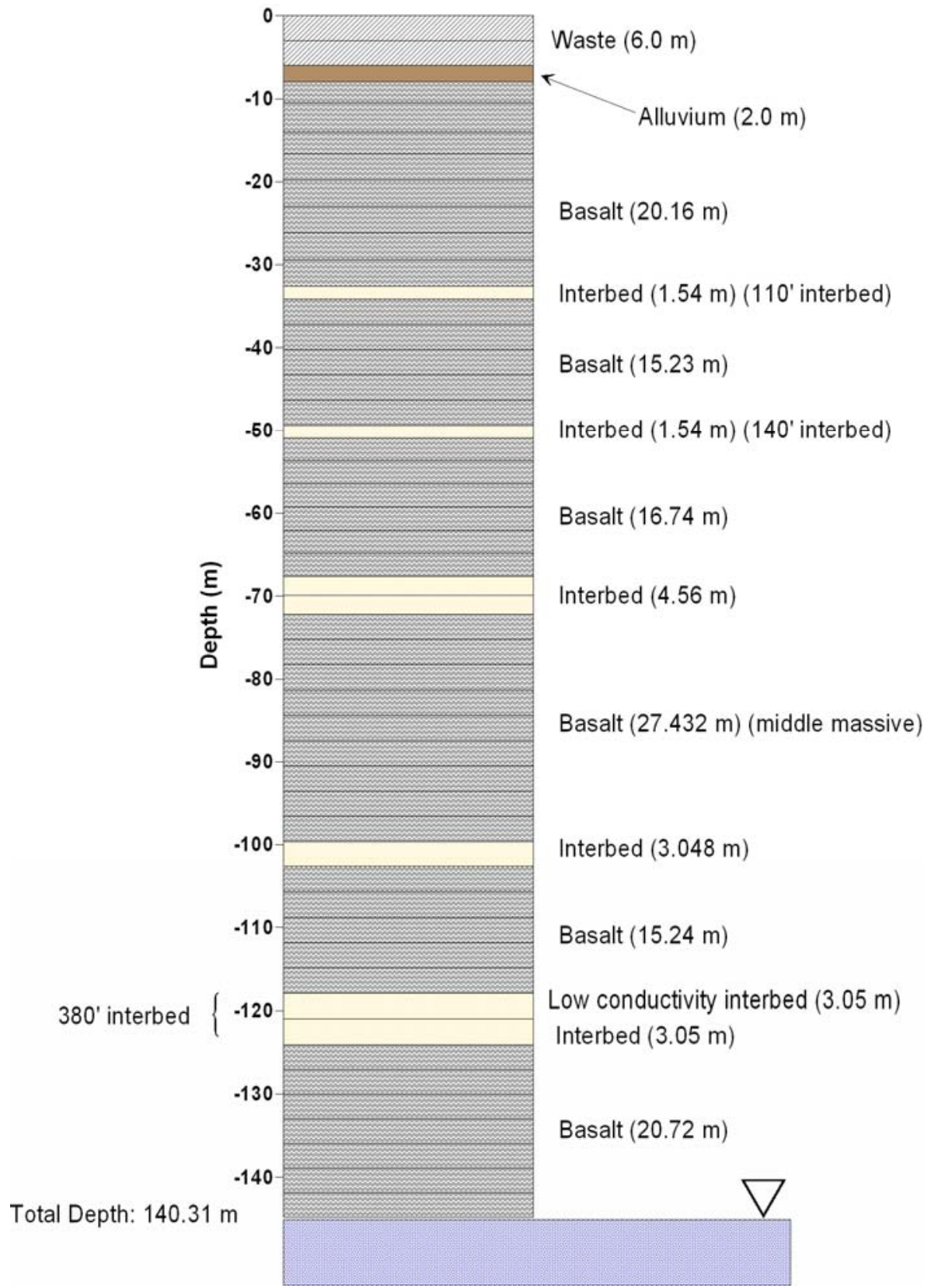

Figure 12. Discretization of the cement-sand-vault system, alluvial base layer, basalt, and sedimentary interbeds used to represent the subsurface at Site 34 (near INTEC). 
Dissolution is used to represent releases that occur as activated metals break down over time. Activation products are often integral to the base metal and are assumed to be released by dissolution as the metal corrodes. The most conservative corrosion rates at INL were determined for immersion tests conducted at INTEC (1,312 to 1,968 year/mm), where Type 304 stainless steel coupons were subjected to a magnesium chloride solution at a 6-m burial depth temperature and oxygen content. The magnesium chloride solution was used to represent the long-term use of a dust suppressant at RWMC. A value similar in magnitude was recommended for use at the Subsurface Disposal Area by Nagata and Banaee (1996). This value $(4,500$ years $/ \mathrm{mm}$ or $2.22 \mathrm{E}-05 \mathrm{~cm} /$ year) comes from corrosion of sensitized Type 304 stainless steel buried in soils near Toppenish, Washington. These two rates are both greater than the rates measured by Adler Flitton et al. (2011) for activated metal types expected to be deposited in the proposed RH-LLW facility. Based on direct testing of coupons buried $1.22 \mathrm{~m}(4 \mathrm{ft})$ and $3.05 \mathrm{~m}(10 \mathrm{ft})$ below ground surface near RWMC, Adler Flitton et al. (2011) measured corrosion rates for aluminum, zircaloy, inconel, and various types of stainless steel (304, 316L and 316L welded) after 1 year, 3 years, 6 years, and 12 years of burial. Corrosion rates decreased with burial depth and with time of burial for all reported results.

In addition to corrosion data, a geometric shape factor (surface-area-to-volume ratio) is required to calculate the fractional release of radionuclides from activated metal components. Based on a study of power reactors (Oztunali and Roles 1986), a surface-area-to-volume ratio of $0.535 \mathrm{~cm}^{-1}$ was used for typical INL-type reactor components. Combining the Nagata and Banaee (1996) corrosion rate (2.22E-05 $\mathrm{cm} / \mathrm{yr})$ with the Oztunali and Roles (1986) geometry factor $\left(0.535 \mathrm{~cm}^{-1}\right)$ results in a fractional release rate from stainless steel of 1.19E-05/year. In comparison, fractional release rates using average 12-yr corrosion rates from Adler Flitton et al. (2011) for different metal types (see Table 3), are less by one to three orders of magnitude. For conservatism, 1.19E-05/year was used in this analysis for the fractional release rate from activated metals. This same value was used for the RWMC PA (DOE-ID 2007a).

Table 3. Corrosion rates and fractional release rates for buried metals in Idaho National Laboratory soils.

\begin{tabular}{|c|c|c|c|}
\hline \multirow[b]{2}{*}{ Metal } & \multicolumn{2}{|c|}{ Corrosion Rate } & \multirow{2}{*}{$\begin{array}{c}\text { Fractional } \\
\text { Release Rate }^{\mathrm{a}} \\
\text { year }^{-1}\end{array}$} \\
\hline & mils/year & $\mathrm{cm} /$ year & \\
\hline Aluminum & $7.86 \mathrm{E}-04$ & $2.00 \mathrm{E}-06$ & $1.07 \mathrm{E}-06$ \\
\hline $\begin{array}{l}\text { Stainless steel: 304L, 316L, 316L } \\
\text { welded }\end{array}$ & $5.17 \mathrm{E}-05$ & $1.31 \mathrm{E}-07$ & 7.01E-08 \\
\hline Inconel and Zircaloy & $4.75 \mathrm{E}-05$ & $1.21 \mathrm{E}-07$ & $6.47 \mathrm{E}-08$ \\
\hline
\end{tabular}

The same source release models will be adopted for both candidate sites. The surface wash model will be represented in MCM as a 10-m $\times 240$-m soil-radionuclide mixture $6 \mathrm{~m}$ deep containing the debris and resin source inventories. The activated metals will be represented as an influx of radionuclides with the rate equal to the inventory of each radionuclide in activated metal times the fractional release rate from stainless steel. The fractional release rate of 1.19E-05/year was used in the Phase IV screening analysis (DOE-ID 2007a). It is conservative for all metal types expected to be deposited in the proposed RH-LLW disposal facility. At both sites, the facility is assumed to be oriented with the long-axis perpendicular to the aquifer flow direction.

4.4.2.2 Infiltration Rate. As implied above, during the operational period, infiltration into the facility will not contact the waste emplaced in the steel liners and concrete vaults. After capping the facility, infiltration through the waste zone will be small by design. In Phase III the infiltration rate was assumed to be $10 \mathrm{~cm} /$ year. In Phase IV, a conservative infiltration rate of $1 \mathrm{~cm} /$ year, which is equal to the estimated background infiltration rate for undisturbed soils (Cecil et al. 1992) will be used. One 
centimeter per year essentially neglects the engineered cover that will be placed over the facility during facility closure.

4.4.2.3 Sorption Characteristics. $\mathrm{K}_{\mathrm{d}}$ values for radionuclides evaluated in the Phase IV screening were taken from INL $(20110 \mathrm{c})$ and are presented in Table 4. Sorption was assumed to occur in the compacted sand/gravel base layer, the surface alluvium below the base layer (above the basalt), and the sedimentary interbeds. Sorption was conservatively neglected for the waste zone, the vadose zone basalt, | and the aquifer. The recommended values for natural alluvium (INL 2011日e) were used for the sedimentary interbeds. It was assumed that the downward migration of cement-affected water would impact both the compacted sand/gravel base layer and the surface alluvium, and the recommended cement impacted alluvium values from INL $(201 \underline{1} \theta$ e) were used for both.

Table 4. Distribution coefficients used in the Phase IV screening analysis (all values from INL 20110c).

\begin{tabular}{|c|c|c|c|c|c|}
\hline Element & $\begin{array}{l}\text { Waste Zone } \\
\mathrm{K}_{\mathrm{d}}(\mathrm{mL} / \mathrm{g})\end{array}$ & $\begin{array}{c}\text { Base Layer } \\
\mathrm{K}_{\mathrm{d}}(\mathrm{mL} / \mathrm{g})\end{array}$ & $\begin{array}{l}\text { Alluvium below } \\
\text { Base Layer } \\
\mathrm{K}_{\mathrm{d}}(\mathrm{mL} / \mathrm{g}) \\
\end{array}$ & $\begin{array}{c}\text { Interbed } \\
\mathrm{K}_{\mathrm{d}}(\mathrm{mL} / \mathrm{g})\end{array}$ & $\begin{array}{c}\text { Basalt } \\
\mathrm{K}_{\mathrm{d}}(\mathrm{mL} / \mathrm{g}) \\
\end{array}$ \\
\hline Ac & 0 & 360 & 360 & 300 & 0 \\
\hline $\mathrm{C}$ & 0 & 2 & 2 & 0.5 & 0 \\
\hline $\mathrm{Cl}$ & 0 & 0 & 0 & 0 & 0 \\
\hline $\mathrm{H}$ & 0 & 0 & 0 & 0 & 0 \\
\hline I & 0 & 0.3 & 0.3 & 3 & 0 \\
\hline Mo & 0 & 14 & 14 & 10 & 0 \\
\hline $\mathrm{Nb}$ & 0 & 224 & 224 & 160 & 0 \\
\hline $\mathrm{Ni}$ & 0 & 30 & 30 & 100 & 0 \\
\hline $\mathrm{Np}$ & 0 & 17.5 & 17.5 & 17.5 & 0 \\
\hline $\mathrm{Pa}$ & 0 & 825 & 825 & 550 & 0 \\
\hline $\mathrm{Pb}$ & 0 & 54 & 54 & 270 & 0 \\
\hline $\mathrm{Pu}$ & 0 & 1,480 & 1,480 & 1,140 & 0 \\
\hline $\mathrm{Ra}$ & 0 & 250 & 250 & 500 & 0 \\
\hline Tc & 0 & 0.01 & 0.01 & 0.1 & 0 \\
\hline Th & 0 & 150 & 150 & 500 & 0 \\
\hline $\mathrm{U}$ & 0 & 10 & 10 & 10 & 0 \\
\hline
\end{tabular}

INL (2011 $\underline{e})$ reports that $\mathrm{K}_{\mathrm{d}}$ values for radionuclide sorption to INL sediment are variable, but generally correlate with cation exchange capacity (CEC). The correlation is imprecise, but CEC differences can be used as a guide for applying $\mathrm{K}_{\mathrm{d}}$ values measured at one location to a different location. Cooper (INL 2010b) provides a range of $\mathrm{K}_{\mathrm{d}}$ values for INL alluvium at Site 5 . The CEC values of the alluvium at Site 5 fall within the range of CEC values that describes the majority of INL sitewide sediment. This similarity in the CEC of alluvium sediment allows $\mathrm{K}_{\mathrm{d}}$ values estimated for Site 5 alluvium to be used as an INL sitewide average for preliminary assessments involving radionuclide transport through the alluvium. This assessment assumes the alluvium sediment at Site 34 is similar enough to the alluvium sediment at Site 5 (relatively fine-grained, distinct from the gravel beneath the INTEC tank farm), and uses $K_{d}$ values from Site 5 as a proxy for $K_{d}$ values in the alluvium at Site 34 . 
This assessment also assumes that the $\mathrm{K}_{\mathrm{d}}$ values for the interbeds at Site 5 can be applied to the interbeds at Site 34. This assumption is based on two premises. First, the CEC values of the interbeds at Site 5 fall within the range of CEC values that describes the majority of sitewide interbed sediment. As with the alluvium $\mathrm{K}_{\mathrm{d}}$, this similarity means that interbed $\mathrm{K}_{\mathrm{d}}$ values for Site 5 can be used to describe radionuclide transport in preliminary assessments. Second, available data indicate the interbeds beneath Site 34 have a textural composition that is comparable to that at Site 5. DOE-ID (2003b) reports that interbed sediment at INTEC (near site 34 ) has a textural composition that is approximately $16 \%$ clay, $44 \%$ silt $(60 \%$ clay + silt), $28 \%$ sand, and $12 \%$ gravel (40\% sand + gravel). Doornbos et al. (1991) report that interbed sediment at the ATR Complex near Site 5 has a textural composition that is approximately $23 \%$ clay, $39 \%$ silt $(62 \%$ clay + silt), $38 \%$ sand, and $1 \%$ gravel $(39 \%$ sand + gravel). These sites have different ratios of clay to silt and sand to gravel, but their sum total of "clay + silt" and "sand + gravel" are similar. CEC values do generally increase with clay content at INL; however, the correlation is imprecise and clay content is not predictive of CEC. However, the range of CEC values for sediment from different locations with comparable clay + silt content will generally overlap. Therefore, it is reasonable to assume for this assessment that $\mathrm{K}_{\mathrm{d}}$ values for interbeds at Site 5 also will be applicable to Site 34 .

4.4.2.4 Dispersivity. Dispersivity used in the Phase IV analysis was taken from the ICDF performance assessment (DOE-ID 2010). The vertical dispersivity in the vadose zone was $1.44 \mathrm{~m}$ based on the implicit dispersion in the MCM model (see Equations 35 through 37). Three-dimensional dispersivity in the aquifer was assigned values of $3.31 \mathrm{~m}, 0.662 \mathrm{~m}$, and $0.00384 \mathrm{~m}$ in the longitudinal, transverse, and vertical directions, respectively. These values were used to represent dispersion at both sites.

4.4.2.5 Other Model Parameters. Other model parameters were the same as applied in the Phase III screening step (Table 2), with the exception of the hydraulic moisture characteristics and the receptor distance in the aquifer. Van Genuchten parameters were used with a Mualem model to represent hydraulic characteristics at both sites. These values are shown in Tables 5 and 6 for Site 5 and Site 34, respectively. At both sites, high-permeability alluvium representative of INTEC alluvium was used for the cement-vault system and the alluvial base layer. Low and high-permeability interbeds have been characterized at INTEC through the CERCLA investigations (DOE-ID 2006a) and are represented by the values shown in Table 6. Properties for Site 5 interbeds were determined by the U.S. Geological Survey

| for nearby well ICPP-SCI-V-214 (DOE-ID 2003c; DOE-ID 2005b; DOE-ID 2008). Properties for the basalt were derived from modeling of the INL Large Scale Infiltration Test and were documented in Magnuson (1995). Fractured basalt parameters retained the saturated conductivity, residual saturation, and total porosity of Magnuson (1995). Unsaturated moisture characteristic parameters for the Van Genuchten (1980) relationship were selected to allow ready drainage at low moisture content and rapid increase in relative conductivity at low saturation. Using a low alpha $\left(2.5 \mathrm{~m}^{-1}\right)$ and high $\mathrm{n}(10)$ is consistent with the Brooks-Corey parameters developed by Magnuson (1995).

The receptor in the aquifer was placed $100 \mathrm{~m}$ downgradient from the downgradient edge of the facility as specified in DOE Order 435.1.

\section{RESULTS}

Results of the four screening and analysis phases are discussed in the following subsections.

\subsection{Phase I Results}

Phase I removed 143 radionuclides with half-lives of 1-year or less from further consideration. In addition, 13 radionuclides with half lives greater than 1 year were removed because they have no dose conversion factor or MCL. 
Table 5. Hydraulic parameters used to represent flow at Site 5.

\begin{tabular}{|c|c|c|c|c|c|c|c|c|c|}
\hline Lithology & $\begin{array}{l}\text { Saturated } \\
\text { Hydraulic } \\
\text { Conductivity } \\
\text { (m/year) }\end{array}$ & $\begin{array}{c}\text { Total } \\
\text { Porosity }\end{array}$ & $\begin{array}{l}\text { Residual } \\
\text { Moisture } \\
\text { Content }\end{array}$ & $\begin{array}{c}\text { Van } \\
\text { Genuchten } \\
\text { Fitting } \\
\text { Parameter } \\
n\end{array}$ & $\begin{array}{c}\text { Van } \\
\text { Genuchten } \\
\text { Fitting } \\
\text { Parameter } \\
\alpha(1 / \mathrm{m})\end{array}$ & $\begin{array}{c}\text { Van } \\
\text { Genuchten } \\
\text { Fitting } \\
\text { Parameter } \\
m\end{array}$ & $\begin{array}{c}\text { Mualem } \\
\text { Fitting } \\
\text { Parameter } \\
L \\
\end{array}$ & $\begin{array}{c}\text { Bulk } \\
\text { Density } \\
\left(\mathrm{g} / \mathrm{cm}^{3}\right)\end{array}$ & Reference \\
\hline $\begin{array}{l}\text { High-permeability } \\
\text { alluvium and waste }\end{array}$ & 8,798 & 0.32 & 0.0002 & 1.4 & 100 & 0.29 & 0.5 & 1.82 & DOE-ID (2006a) \\
\hline Interbed & 1.258 & 0.459 & 0.165 & 1.4 & 0.052 & 0.83 & 9.25 & 1.5 & $\begin{array}{l}\text { Based on best fit of } \\
\text { hydraulic data from well } \\
\text { ICPP-SCI-V-213 (38-ft) } \\
\text { (DOE-ID 2004), Bulk } \\
\text { density (DOE-ID 1994) }\end{array}$ \\
\hline $\begin{array}{l}\text { Unsaturated } \\
\text { fractured basalt }\end{array}$ & $\begin{array}{r}91^{\mathrm{a}} \\
(300 \mathrm{mDarcy}) \\
\end{array}$ & $0.05^{\mathrm{a}}$ & $0.001^{\mathrm{a}}$ & $10^{\mathrm{b}}$ & $2.5^{\mathrm{b}}$ & $0.90^{\mathrm{b}}$ & $0.5^{\mathrm{b}}$ & 2 & $\begin{array}{l}\text { See footnotes, Bulk } \\
\text { density assumed }\end{array}$ \\
\hline
\end{tabular}


Table 6. Hydraulic parameters used to represent flow at Site 34.

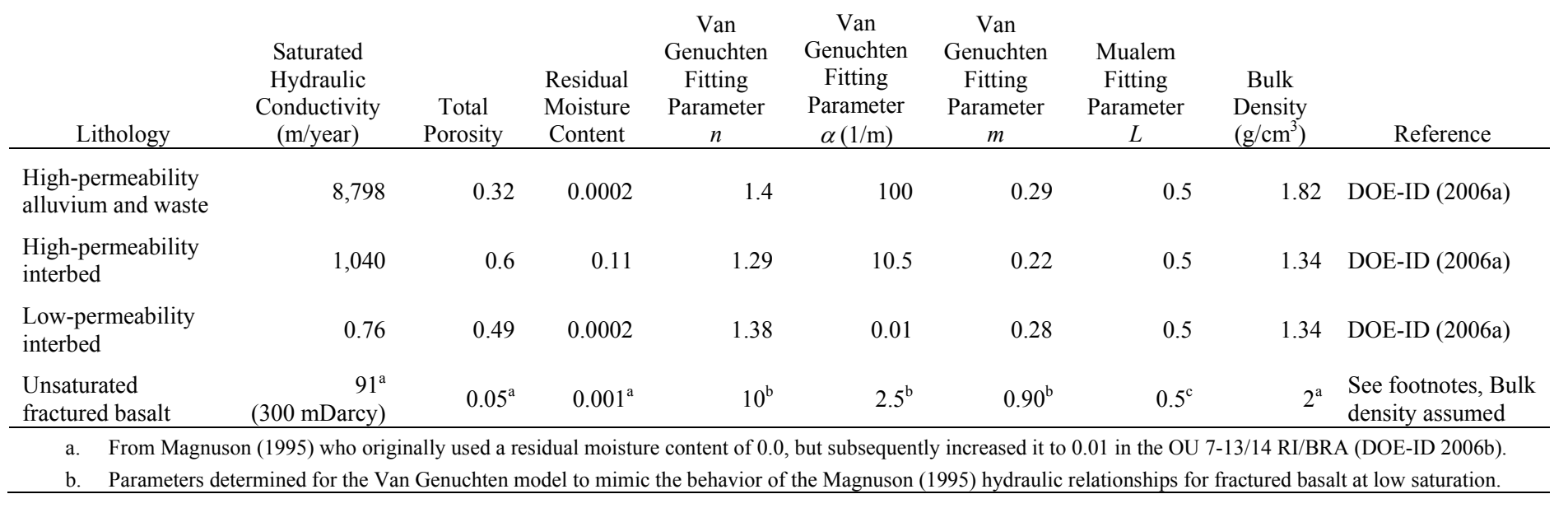


These 13 radionuclides are mostly stable elements or noble gases. Therefore, a total of 156 radionuclides were removed from the inventory shown in Table 1. The remaining 90 radionuclides were retained for Phase II consideration. These 90 radionuclides, with their inventory and half-lives, are shown in Table 7. These results are not site dependent and apply to both Site 5 and Site 34.

Table 7. Phase I screening results based on half-life.

\begin{tabular}{|c|c|c|c|c|c|}
\hline Radionuclide & $\begin{array}{l}\text { Inventory } \\
\text { (Ci) }\end{array}$ & $\begin{array}{c}\text { Half-Life } \\
\text { (years) }\end{array}$ & Radionuclide & $\begin{array}{l}\text { Inventory } \\
\text { (Ci) }\end{array}$ & $\begin{array}{c}\text { Half-Life } \\
\text { (years) }\end{array}$ \\
\hline Ac-227 & $1.85 \mathrm{E}-06$ & $2.18 \mathrm{E}+01$ & Np-237 & 2.99E-03 & $2.14 \mathrm{E}+06$ \\
\hline Ag-108m & $2.92 \mathrm{E}-05$ & $1.27 \mathrm{E}+02$ & Os-194 & 4.05E-09 & $6.00 \mathrm{E}+00$ \\
\hline Am-241 & $3.91 \mathrm{E}-01$ & $4.32 \mathrm{E}+02$ & $\mathrm{~Pa}-231$ & $8.81 \mathrm{E}-06$ & $3.28 \mathrm{E}+04$ \\
\hline Am-242m & $2.76 \mathrm{E}-03$ & $1.52 \mathrm{E}+02$ & $\mathrm{~Pb}-205$ & 8.32E-07 & $1.43 \mathrm{E}+07$ \\
\hline Am-243 & $1.03 \mathrm{E}-03$ & $7.38 \mathrm{E}+03$ & Pd-107 & $3.16 \mathrm{E}-04$ & $6.50 \mathrm{E}+06$ \\
\hline Ba-133 & $1.83 \mathrm{E}-03$ & $1.07 \mathrm{E}+01$ & Pm-145 & $1.62 \mathrm{E}-10$ & $1.77 \mathrm{E}+01$ \\
\hline Be-10 & $1.80 \mathrm{E}-04$ & $1.60 \mathrm{E}+06$ & Pm-146 & 8.44E-08 & $5.53 \mathrm{E}+00$ \\
\hline $\mathrm{Bi}-210 \mathrm{~m}$ & $1.09 \mathrm{E}-06$ & $3.00 \mathrm{E}+06$ & Pm-147 & $8.80 \mathrm{E}+03$ & $2.62 \mathrm{E}+00$ \\
\hline C-14 & $4.32 \mathrm{E}+02$ & $5.73 \mathrm{E}+03$ & Pt-193 & $9.08 \mathrm{E}-04$ & $5.00 \mathrm{E}+01$ \\
\hline $\mathrm{Ca}-41$ & $1.35 \mathrm{E}-02$ & $1.40 \mathrm{E}+05$ & $\mathrm{Pu}-236$ & $7.06 \mathrm{E}-07$ & $2.85 \mathrm{E}+00$ \\
\hline Cd-109 & $3.97 \mathrm{E}-01$ & $1.27 \mathrm{E}+00$ & $\mathrm{Pu}-238$ & $6.85 \mathrm{E}-01$ & $8.77 \mathrm{E}+01$ \\
\hline Cd-113m & $5.64 \mathrm{E}-02$ & $1.36 \mathrm{E}+01$ & $\mathrm{Pu}-239$ & 4.67E-01 & $2.41 \mathrm{E}+04$ \\
\hline Cf-249 & $1.02 \mathrm{E}-11$ & $3.51 \mathrm{E}+02$ & $\mathrm{Pu}-240$ & $2.48 \mathrm{E}-01$ & $6.54 \mathrm{E}+03$ \\
\hline Cf-250 & $1.47 \mathrm{E}-10$ & $1.31 \mathrm{E}+01$ & $\mathrm{Pu}-241$ & $2.71 \mathrm{E}+01$ & $1.44 \mathrm{E}+01$ \\
\hline Cf-251 & $3.25 \mathrm{E}-13$ & $8.98 \mathrm{E}+02$ & $\mathrm{Pu}-242$ & $3.85 \mathrm{E}-04$ & $3.76 \mathrm{E}+05$ \\
\hline $\mathrm{Cl}-36$ & $1.53 \mathrm{E}-01$ & $3.01 \mathrm{E}+05$ & $\mathrm{Ra}-226$ & $8.00 \mathrm{E}-11$ & $1.60 \mathrm{E}+03$ \\
\hline $\mathrm{Cm}-243$ & $1.90 \mathrm{E}-03$ & $2.85 \mathrm{E}+01$ & $\mathrm{Ra}-228$ & $2.96 \mathrm{E}-07$ & $5.75 \mathrm{E}+00$ \\
\hline $\mathrm{Cm}-244$ & $7.70 \mathrm{E}-02$ & $1.81 \mathrm{E}+01$ & $\mathrm{Rb}-87$ & $1.28 \mathrm{E}-06$ & $4.70 \mathrm{E}+10$ \\
\hline $\mathrm{Cm}-245$ & $1.50 \mathrm{E}-06$ & $8.50 \mathrm{E}+03$ & Re-187 & 8.94E-01 & $5.00 \mathrm{E}+10$ \\
\hline $\mathrm{Cm}-246$ & $1.06 \mathrm{E}-06$ & $4.73 \mathrm{E}+03$ & Rh-102 & $1.23 \mathrm{E}-04$ & $2.90 \mathrm{E}+00$ \\
\hline $\mathrm{Cm}-247$ & $4.88 \mathrm{E}-13$ & $1.56 \mathrm{E}+07$ & Ru-106 & $3.12 \mathrm{E}+03$ & $1.01 \mathrm{E}+00$ \\
\hline Co- 60 & $2.90 \mathrm{E}+06$ & $5.27 \mathrm{E}+00$ & $\mathrm{Sb}-125$ & $3.53 \mathrm{E}+04$ & $2.77 \mathrm{E}+00$ \\
\hline Cs-134 & $3.83 \mathrm{E}+02$ & $2.06 \mathrm{E}+00$ & Se-79 & $8.44 \mathrm{E}-03$ & $6.50 \mathrm{E}+04$ \\
\hline Cs-135 & $1.55 \mathrm{E}-02$ & $2.30 \mathrm{E}+06$ & Si-32 & $6.65 \mathrm{E}-07$ & $4.50 \mathrm{E}+02$ \\
\hline Cs-137 & $6.27 \mathrm{E}+03$ & $3.00 \mathrm{E}+01$ & Sm-147 & $4.38 \mathrm{E}-10$ & $1.06 \mathrm{E}+11$ \\
\hline Eu-152 & $1.04 \mathrm{E}+01$ & $1.33 \mathrm{E}+01$ & Sm-151 & $4.86 \mathrm{E}+01$ & $9.00 \mathrm{E}+01$ \\
\hline Eu-154 & $2.45 \mathrm{E}+02$ & $8.80 \mathrm{E}+00$ & Sn-121m & $1.38 \mathrm{E}+02$ & $5.50 \mathrm{E}+01$ \\
\hline Eu-155 & $3.90 \mathrm{E}+02$ & $4.96 \mathrm{E}+00$ & Sn-126 & $1.98 \mathrm{E}-04$ & $1.00 \mathrm{E}+05$ \\
\hline $\mathrm{Fe}-55$ & $1.19 \mathrm{E}+06$ & $2.70 \mathrm{E}+00$ & Sr-90 & $6.18 \mathrm{E}+03$ & $2.91 \mathrm{E}+01$ \\
\hline $\mathrm{H}-3$ & $3.92 \mathrm{E}+03$ & $1.24 \mathrm{E}+01$ & Тa-180 & $6.97 \mathrm{E}-01$ & $1.00 \mathrm{E}+13$ \\
\hline Hf- $178 \mathrm{~m}$ & 4.01E-08 & $3.10 \mathrm{E}+01$ & Tc-99 & $1.67 \mathrm{E}+01$ & $2.13 \mathrm{E}+05$ \\
\hline
\end{tabular}


Table 7. (continued).

\begin{tabular}{lcclcc}
\hline \multicolumn{1}{c}{ Radionuclide } & $\begin{array}{c}\text { Inventory } \\
\text { (Ci) }\end{array}$ & $\begin{array}{c}\text { Half-Life } \\
\text { (years) }\end{array}$ & Radionuclide & $\begin{array}{c}\text { Inventory } \\
(\mathrm{Ci})\end{array}$ & $\begin{array}{c}\text { Half-Life } \\
\text { (years) }\end{array}$ \\
\hline Hf-182 & $1.15 \mathrm{E}-04$ & $9.00 \mathrm{E}+06$ & Te-123 & $5.07 \mathrm{E}-09$ & $1.00 \mathrm{E}+13$ \\
Ho-166m & $5.57 \mathrm{E}-08$ & $1.20 \mathrm{E}+03$ & Th-228 & $2.89 \mathrm{E}-04$ & $1.91 \mathrm{E}+00$ \\
I-129 & $1.33 \mathrm{E}-01$ & $1.57 \mathrm{E}+07$ & Th-229 & $6.38 \mathrm{E}-08$ & $7.34 \mathrm{E}+03$ \\
In-115 & $4.91 \mathrm{E}-13$ & $5.10 \mathrm{E}+15$ & Th-230 & $6.82 \mathrm{E}-08$ & $7.70 \mathrm{E}+04$ \\
Ir-192m & $1.11 \mathrm{E}-05$ & $2.41 \mathrm{E}+02$ & Th-232 & $3.12 \mathrm{E}-07$ & $1.41 \mathrm{E}+10$ \\
K-40 & $1.26 \mathrm{E}-03$ & $1.28 \mathrm{E}+09$ & Tl-204 & $2.19 \mathrm{E}-22$ & $3.78 \mathrm{E}+00$ \\
La-137 & $2.38 \mathrm{E}-06$ & $6.00 \mathrm{E}+04$ & Tm-171 & $3.46 \mathrm{E}-07$ & $1.92 \mathrm{E}+00$ \\
Lu-176 & $1.50 \mathrm{E}-08$ & $3.60 \mathrm{E}+10$ & $\mathrm{U}-232$ & $3.59 \mathrm{E}-04$ & $7.20 \mathrm{E}+01$ \\
Mo-93 & $2.91 \mathrm{E}+01$ & $3.50 \mathrm{E}+03$ & $\mathrm{U}-233$ & $1.18 \mathrm{E}-04$ & $1.59 \mathrm{E}+05$ \\
Nb-93m & $6.98 \mathrm{E}+02$ & $1.36 \mathrm{E}+01$ & $\mathrm{U}-234$ & $1.20 \mathrm{E}-03$ & $2.45 \mathrm{E}+05$ \\
Nb-94 & $1.11 \mathrm{E}+02$ & $2.03 \mathrm{E}+04$ & $\mathrm{U}-235$ & $5.14 \mathrm{E}-03$ & $7.04 \mathrm{E}+08$ \\
Ni-59 & $3.24 \mathrm{E}+03$ & $7.50 \mathrm{E}+04$ & $\mathrm{U}-236$ & $1.29 \mathrm{E}-04$ & $2.34 \mathrm{E}+07$ \\
Ni-63 & $3.92 \mathrm{E}+05$ & $9.60 \mathrm{E}+01$ & $\mathrm{U}-238$ & $1.62 \mathrm{E}+01$ & $4.47 \mathrm{E}+09$ \\
Np-235 & $2.49 \mathrm{E}-09$ & $1.08 \mathrm{E}+00$ & Zr-93 & $4.37 \mathrm{E}+01$ & $1.53 \mathrm{E}+06$ \\
\hline
\end{tabular}

\subsection{Phase II Results}

Phase II applies the NCRP screening process to the 90 radionuclides contained in Table 7 . In this step, 33 radionuclides with an NCRP screening dose less than 0.4-mrem/year EDE were removed from further consideration. Fifty-seven radionuclides have an NCRP dose greater than 0.4-mrem/year EDE and were retained for Phase III consideration. The entire list of radionuclides has been sorted by the NCRP screening dose and is shown in Table 8. Retained radionuclides are indicated by a "Yes" in Column 5 of Table 8; those that are not retained are indicated by a "No." As with Phase I, this step is not site dependent and results apply to both Site 5 and Site 34 .

Table 8. Phase II screening results using the National Council on Radiation Protection screening factors.

\begin{tabular}{lcccc}
\hline \multicolumn{1}{c}{ Radionuclide } & $\begin{array}{c}\text { Inventory } \\
(\mathrm{Ci})\end{array}$ & $\begin{array}{c}\text { NCRP Screening Factor } \\
(\mathrm{mrem} / \mathrm{Ci})\end{array}$ & $\begin{array}{c}\text { NCRP Screening Dose } \\
(\mathrm{mrem} / \text { year EDE) }\end{array}$ & Retained \\
\hline Co-60 & $2.90 \mathrm{E}+06$ & $2.44 \mathrm{E}+01$ & $7.09 \mathrm{E}+10$ & Yes \\
Sr-90 & $6.18 \mathrm{E}+03$ & $1.33 \mathrm{E}+02$ & $8.23 \mathrm{E}+08$ & Yes \\
Cs-137 & $6.27 \mathrm{E}+03$ & $5.18 \mathrm{E}+01$ & $3.25 \mathrm{E}+08$ & Yes \\
Ni-63 & $3.92 \mathrm{E}+05$ & $1.52 \mathrm{E}-01$ & $5.95 \mathrm{E}+07$ & Yes \\
Sb-125 & $3.53 \mathrm{E}+04$ & $1.30 \mathrm{E}+00$ & $4.58 \mathrm{E}+07$ & Yes \\
C-14 & $4.32 \mathrm{E}+02$ & $6.29 \mathrm{E}+01$ & $2.72 \mathrm{E}+07$ & Yes \\
U-238 & $1.62 \mathrm{E}+01$ & $6.29 \mathrm{E}+02$ & $1.02 \mathrm{E}+07$ & Yes \\
Nb-94 & $1.11 \mathrm{E}+02$ & $6.29 \mathrm{E}+01$ & $6.96 \mathrm{E}+06$ & Yes \\
Eu-154 & $2.45 \mathrm{E}+02$ & $2.00 \mathrm{E}+01$ & $4.90 \mathrm{E}+06$ & Yes \\
H-3 & $3.92 \mathrm{E}+03$ & $1.15 \mathrm{E}+00$ & $4.49 \mathrm{E}+06$ & Yes \\
\hline
\end{tabular}


Table 8. (continued).

\begin{tabular}{|c|c|c|c|c|}
\hline Radionuclide & $\begin{array}{l}\text { Inventory } \\
(\mathrm{Ci})\end{array}$ & $\begin{array}{l}\text { NCRP Screening Factor } \\
(\mathrm{mrem} / \mathrm{Ci})\end{array}$ & $\begin{array}{l}\text { NCRP Screening Dose } \\
\text { (mrem/year EDE) }\end{array}$ & Retained \\
\hline $\mathrm{Fe}-55$ & $1.19 \mathrm{E}+06$ & $3.66 \mathrm{E}-03$ & $4.37 \mathrm{E}+06$ & Yes \\
\hline Cs-134 & $3.83 \mathrm{E}+02$ & $3.70 \mathrm{E}+00$ & $1.42 \mathrm{E}+06$ & Yes \\
\hline Tc-99 & $1.67 \mathrm{E}+01$ & $4.81 \mathrm{E}+01$ & $8.05 \mathrm{E}+05$ & Yes \\
\hline $\mathrm{Sn}-121 \mathrm{~m}$ & $1.38 \mathrm{E}+02$ & $3.70 \mathrm{E}+00$ & $5.09 \mathrm{E}+05$ & Yes \\
\hline Eu-152 & $1.04 \mathrm{E}+01$ & $2.44 \mathrm{E}+01$ & $2.54 \mathrm{E}+05$ & Yes \\
\hline Eu-155 & $3.90 \mathrm{E}+02$ & $6.29 \mathrm{E}-01$ & $2.46 \mathrm{E}+05$ & Yes \\
\hline $\mathrm{Ni}-59$ & $3.24 \mathrm{E}+03$ & 7.03E-02 & $2.28 \mathrm{E}+05$ & Yes \\
\hline $\mathrm{I}-129$ & $1.33 \mathrm{E}-01$ & $7.40 \mathrm{E}+02$ & $9.87 \mathrm{E}+04$ & Yes \\
\hline Pm-147 & $8.80 \mathrm{E}+03$ & $6.29 \mathrm{E}-03$ & $5.53 \mathrm{E}+04$ & Yes \\
\hline $\mathrm{Cl}-36$ & $1.53 \mathrm{E}-01$ & $2.63 \mathrm{E}+02$ & $4.03 \mathrm{E}+04$ & Yes \\
\hline $\mathrm{Nb}-93 \mathrm{~m}$ & $6.98 \mathrm{E}+02$ & $4.81 \mathrm{E}-02$ & $3.36 \mathrm{E}+04$ & Yes \\
\hline $\mathrm{Pu}-241$ & $2.71 \mathrm{E}+01$ & $1.07 \mathrm{E}+00$ & $2.91 \mathrm{E}+04$ & Yes \\
\hline Mo-93 & $2.91 \mathrm{E}+01$ & $9.62 \mathrm{E}-01$ & $2.80 \mathrm{E}+04$ & Yes \\
\hline $\mathrm{Pu}-238$ & $6.85 \mathrm{E}-01$ & $2.92 \mathrm{E}+01$ & $2.00 \mathrm{E}+04$ & Yes \\
\hline Тa-180 & $6.97 \mathrm{E}-01$ & $2.78 \mathrm{E}+01$ & $1.93 \mathrm{E}+04$ & Yes \\
\hline $\mathrm{Pu}-239$ & 4.67E-01 & $3.52 \mathrm{E}+01$ & $1.64 \mathrm{E}+04$ & Yes \\
\hline Am-241 & $3.91 \mathrm{E}-01$ & $3.11 \mathrm{E}+01$ & $1.21 \mathrm{E}+04$ & Yes \\
\hline $\mathrm{Pu}-240$ & $2.48 \mathrm{E}-01$ & $3.48 \mathrm{E}+01$ & $8.61 \mathrm{E}+03$ & Yes \\
\hline Cd-113m & $5.64 \mathrm{E}-02$ & $1.15 \mathrm{E}+02$ & $6.47 \mathrm{E}+03$ & Yes \\
\hline Zr-93 & $4.37 \mathrm{E}+01$ & $9.62 \mathrm{E}-02$ & $4.21 \mathrm{E}+03$ & Yes \\
\hline $\mathrm{Np}-237$ & $2.99 \mathrm{E}-03$ & $1.11 \mathrm{E}+03$ & $3.32 \mathrm{E}+03$ & Yes \\
\hline $\mathrm{Cm}-244$ & $7.70 \mathrm{E}-02$ & $1.11 \mathrm{E}+01$ & $8.54 \mathrm{E}+02$ & Yes \\
\hline Sm-151 & $4.86 \mathrm{E}+01$ & $1.11 \mathrm{E}-02$ & $5.40 \mathrm{E}+02$ & Yes \\
\hline$A m-242 m$ & $2.76 \mathrm{E}-03$ & $1.92 \mathrm{E}+02$ & $5.32 \mathrm{E}+02$ & Yes \\
\hline U-235 & $5.14 \mathrm{E}-03$ & $7.40 \mathrm{E}+01$ & $3.80 \mathrm{E}+02$ & Yes \\
\hline Cs-135 & $1.55 \mathrm{E}-02$ & $6.29 \mathrm{E}+00$ & $9.72 \mathrm{E}+01$ & Yes \\
\hline U-232 & $3.59 \mathrm{E}-04$ & $2.48 \mathrm{E}+02$ & $8.90 \mathrm{E}+01$ & Yes \\
\hline Am-243 & $1.03 \mathrm{E}-03$ & $4.07 \mathrm{E}+01$ & $4.20 \mathrm{E}+01$ & Yes \\
\hline Cd-109 & $3.97 \mathrm{E}-01$ & $1.04 \mathrm{E}-01$ & $4.11 \mathrm{E}+01$ & Yes \\
\hline $\mathrm{K}-40$ & $1.26 \mathrm{E}-03$ & $3.18 \mathrm{E}+01$ & $4.01 \mathrm{E}+01$ & Yes \\
\hline $\mathrm{Cm}-243$ & $1.90 \mathrm{E}-03$ & $2.04 \mathrm{E}+01$ & $3.86 \mathrm{E}+01$ & Yes \\
\hline $\mathrm{Ca}-41$ & $1.35 \mathrm{E}-02$ & $2.37 \mathrm{E}+00$ & $3.19 \mathrm{E}+01$ & Yes \\
\hline U-234 & $1.20 \mathrm{E}-03$ & $2.15 \mathrm{E}+01$ & $2.57 \mathrm{E}+01$ & Yes \\
\hline Se-79 & $8.44 \mathrm{E}-03$ & $2.66 \mathrm{E}+00$ & $2.25 \mathrm{E}+01$ & Yes \\
\hline Sn-126 & $1.98 \mathrm{E}-04$ & $1.11 \mathrm{E}+02$ & $2.20 \mathrm{E}+01$ & Yes \\
\hline
\end{tabular}


Table 8. (continued).

\begin{tabular}{|c|c|c|c|c|}
\hline Radionuclide & $\begin{array}{l}\text { Inventory } \\
\text { (Ci) }\end{array}$ & $\begin{array}{l}\text { NCRP Screening Factor } \\
(\mathrm{mrem} / \mathrm{Ci})\end{array}$ & $\begin{array}{l}\text { NCRP Screening Dose } \\
\text { (mrem/year EDE) }\end{array}$ & Retained \\
\hline Ba-133 & $1.83 \mathrm{E}-03$ & $8.14 \mathrm{E}+00$ & $1.49 \mathrm{E}+01$ & Yes \\
\hline Re-187 & 8.94E-01 & $1.63 \mathrm{E}-02$ & $1.46 \mathrm{E}+01$ & Yes \\
\hline $\mathrm{Pu}-242$ & $3.85 \mathrm{E}-04$ & $3.33 \mathrm{E}+01$ & $1.28 \mathrm{E}+01$ & Yes \\
\hline Hf-182 & $1.15 \mathrm{E}-04$ & $8.51 \mathrm{E}+01$ & $9.80 \mathrm{E}+00$ & Yes \\
\hline U-233 & $1.18 \mathrm{E}-04$ & $5.55 \mathrm{E}+01$ & $6.55 \mathrm{E}+00$ & Yes \\
\hline $\mathrm{Pa}-231$ & $8.81 \mathrm{E}-06$ & $6.29 \mathrm{E}+02$ & $5.54 \mathrm{E}+00$ & Yes \\
\hline U-236 & $1.29 \mathrm{E}-04$ & $1.74 \mathrm{E}+01$ & $2.25 \mathrm{E}+00$ & Yes \\
\hline Ag-108m & $2.92 \mathrm{E}-05$ & $5.92 \mathrm{E}+01$ & $1.73 \mathrm{E}+00$ & Yes \\
\hline Rh-102 & $1.23 \mathrm{E}-04$ & $6.66 \mathrm{E}+00$ & $8.17 \mathrm{E}-01$ & Yes \\
\hline Th-228 & $2.89 \mathrm{E}-04$ & $2.63 \mathrm{E}+00$ & $7.59 \mathrm{E}-01$ & Yes \\
\hline Ir-192m & $1.11 \mathrm{E}-05$ & $4.07 \mathrm{E}+01$ & 4.52E-01 & Yes \\
\hline Ac-227 & $1.85 \mathrm{E}-06$ & $2.41 \mathrm{E}+02$ & 4.45E-01 & Yes \\
\hline Pt-193 & $9.08 \mathrm{E}-04$ & 2.92E-01 & $2.65 \mathrm{E}-01$ & No \\
\hline Th-232 & $3.12 \mathrm{E}-07$ & $3.66 \mathrm{E}+02$ & $1.14 \mathrm{E}-01$ & No \\
\hline $\mathrm{Cm}-245$ & $1.50 \mathrm{E}-06$ & $6.29 \mathrm{E}+01$ & $9.41 \mathrm{E}-02$ & No \\
\hline Bi-210m & $1.09 \mathrm{E}-06$ & $4.07 \mathrm{E}+01$ & $4.45 \mathrm{E}-02$ & No \\
\hline $\mathrm{Si}-32$ & $6.65 \mathrm{E}-07$ & $5.92 \mathrm{E}+01$ & 3.94E-02 & No \\
\hline Be-10 & $1.80 \mathrm{E}-04$ & $2.07 \mathrm{E}-01$ & $3.74 \mathrm{E}-02$ & No \\
\hline Ra-228 & $2.96 \mathrm{E}-07$ & $1.11 \mathrm{E}+02$ & $3.29 \mathrm{E}-02$ & No \\
\hline Pd-107 & $3.16 \mathrm{E}-04$ & $1.04 \mathrm{E}-01$ & $3.28 \mathrm{E}-02$ & No \\
\hline $\mathrm{Cm}-246$ & $1.06 \mathrm{E}-06$ & $3.00 \mathrm{E}+01$ & $3.19 \mathrm{E}-02$ & No \\
\hline Th-230 & $6.82 \mathrm{E}-08$ & $1.59 \mathrm{E}+02$ & $1.09 \mathrm{E}-02$ & No \\
\hline Th-229 & $6.38 \mathrm{E}-08$ & $1.18 \mathrm{E}+02$ & $7.56 \mathrm{E}-03$ & No \\
\hline $\mathrm{Rb}-87$ & $1.28 \mathrm{E}-06$ & $4.44 \mathrm{E}+00$ & $5.67 \mathrm{E}-03$ & No \\
\hline $\mathrm{Pu}-236$ & $7.06 \mathrm{E}-07$ & $5.55 \mathrm{E}+00$ & $3.92 \mathrm{E}-03$ & No \\
\hline Hf- $178 \mathrm{~m}$ & $4.01 \mathrm{E}-08$ & $9.25 \mathrm{E}+01$ & $3.71 \mathrm{E}-03$ & No \\
\hline Ho- $166 \mathrm{~m}$ & $5.57 \mathrm{E}-08$ & $5.92 \mathrm{E}+01$ & $3.30 \mathrm{E}-03$ & No \\
\hline La-137 & $2.38 \mathrm{E}-06$ & $9.62 \mathrm{E}-01$ & $2.29 \mathrm{E}-03$ & No \\
\hline Pm-146 & $8.44 \mathrm{E}-08$ & $7.77 \mathrm{E}+00$ & $6.56 \mathrm{E}-04$ & No \\
\hline Lu-176 & $1.50 \mathrm{E}-08$ & $3.18 \mathrm{E}+01$ & 4.79E-04 & No \\
\hline Tm-171 & $3.46 \mathrm{E}-07$ & $3.70 \mathrm{E}-01$ & $1.28 \mathrm{E}-04$ & No \\
\hline $\mathrm{Pb}-205$ & $8.32 \mathrm{E}-07$ & $6.66 \mathrm{E}-02$ & $5.54 \mathrm{E}-05$ & No \\
\hline $\mathrm{Ra}-226$ & $8.00 \mathrm{E}-11$ & $2.96 \mathrm{E}+02$ & $2.37 \mathrm{E}-05$ & No \\
\hline Os-194 & 4.05E-09 & $2.00 \mathrm{E}+00$ & 8.09E-06 & No \\
\hline Te-123 & $5.07 \mathrm{E}-09$ & $1.26 \mathrm{E}+00$ & $6.38 \mathrm{E}-06$ & No \\
\hline
\end{tabular}


Table 8. (continued).

\begin{tabular}{lcccc}
\hline Radionuclide & $\begin{array}{c}\text { Inventory } \\
(\mathrm{Ci})\end{array}$ & $\begin{array}{c}\text { NCRP Screening Factor } \\
(\mathrm{mrem} / \mathrm{Ci})\end{array}$ & $\begin{array}{c}\text { NCRP Screening Dose } \\
(\mathrm{mrem} / \text { year EDE) }\end{array}$ & Retained \\
\hline Cf-250 & $1.47 \mathrm{E}-10$ & $1.18 \mathrm{E}+01$ & $1.74 \mathrm{E}-06$ & No \\
Sm-147 & $4.38 \mathrm{E}-10$ & $3.70 \mathrm{E}+00$ & $1.62 \mathrm{E}-06$ & No \\
Cf-249 & $1.02 \mathrm{E}-11$ & $5.55 \mathrm{E}+01$ & $5.67 \mathrm{E}-07$ & No \\
Pm-145 & $1.62 \mathrm{E}-10$ & $7.40 \mathrm{E}-01$ & $1.20 \mathrm{E}-07$ & No \\
Np-235 & $2.49 \mathrm{E}-09$ & $2.41 \mathrm{E}-02$ & $5.98 \mathrm{E}-08$ & No \\
Cm-247 & $4.88 \mathrm{E}-13$ & $5.55 \mathrm{E}+01$ & $2.71 \mathrm{E}-08$ & No \\
Cf-251 & $3.25 \mathrm{E}-13$ & $4.81 \mathrm{E}+01$ & $1.56 \mathrm{E}-08$ & No \\
In-115 & $4.91 \mathrm{E}-13$ & $2.96 \mathrm{E}+00$ & $1.45 \mathrm{E}-09$ & No \\
Tl-204 & $2.19 \mathrm{E}-22$ & $4.07 \mathrm{E}-01$ & $8.92 \mathrm{E}-20$ & No \\
Ru-106 & $3.12 \mathrm{E}+03$ & $0.00 \mathrm{E}+00$ & $0.00 \mathrm{E}+00$ & No \\
\hline
\end{tabular}

\subsection{Phase III Results}

Phase III accounts for advection and radioactive chain decay and ingrowth while in the vadose zone and for simple dilution in the aquifer. These results are site-specific and are based on application of the model discussed in Section 4.3 and the model parameterization presented in Section 5. In this step, calculated peak predicted groundwater concentrations were compared to the MCL for each radionuclide. Results for Sites 5 and 34 are shown in Table 9, with predicted peak radionuclide concentrations above their respective MCL shown in the shaded, boxed-cells. This table shows that using this conservative model, the peak concentrations of C-14, H-3, I-129, Ni-59, Tc-99, and U-238 are predicted to be above their respective MCLs and these nuclides were retained for more detailed analysis in Phase IV.

Table 9. Phase III screening results based on site-specific transport.

\begin{tabular}{|c|c|c|c|c|c|}
\hline Radionuclide & $\begin{array}{c}\mathrm{Kd} \\
(\mathrm{mL} / \mathrm{g})\end{array}$ & $\begin{array}{c}\text { Kd } \\
\text { Reference }\end{array}$ & $\begin{array}{c}\text { ATR Complex (Site 5) } \\
\text { Groundwater } \\
\text { Screening } \\
\text { Concentration } \\
(\mathrm{pCi} / \mathrm{L})^{\mathrm{a}} \\
\end{array}$ & $\begin{array}{l}\text { INTEC (Site 34) } \\
\text { Groundwater } \\
\text { Screening } \\
\text { Concentration } \\
(\mathrm{pCi} / \mathrm{L})^{\mathrm{a}} \\
\end{array}$ & $\begin{array}{c}\text { Federal } \\
\text { Maximum } \\
\text { Contaminant } \\
\text { Level } \\
(\mathrm{pCi} / \mathrm{L}) \\
\end{array}$ \\
\hline Ac- 227 & 450 & Jenkins (2001) & 0 & 0 & 15 \\
\hline Ag-108m & 90 & DOE-ID (1994) & 0 & 0 & $627^{\mathrm{b}}$ \\
\hline Am- $241^{d}$ & 2 & DOE-ID (2006a) & $8.9 \mathrm{E}-03$ & $8.9 \mathrm{E}-03$ & 15 \\
\hline Am-242m & 340 & DOE-ID (1994) & 0 & 0 & 15 \\
\hline Am-243 & 340 & DOE-ID (1994) & $4.8 \mathrm{E}-08$ & $5.3 \mathrm{E}-07$ & 15 \\
\hline Ba-133 & 50 & DOE-ID (1994) & 0 & 0 & $967^{\mathrm{b}}$ \\
\hline C-14 & 0 & DOE-ID (1994) & $1.7 \mathrm{E}+06$ & $1.7 \mathrm{E}+06$ & 2,000 \\
\hline $\mathrm{Ca}-41$ & 5 & DOE-ID (1994) & 0.61 & 0.61 & $7,657^{\mathrm{b}}$ \\
\hline Cd-109 & 6 & DOE-ID (1994) & 0 & 0 & 600 \\
\hline Cd-113m & 6 & DOE-ID (1994) & $7.8 \mathrm{E}-42$ & 0 & $60^{\mathrm{b}}$ \\
\hline Cl-36 & 0 & Jenkins (2001) & 616 & 617 & 700 \\
\hline
\end{tabular}


Table 9. (continued).

\begin{tabular}{|c|c|c|c|c|c|}
\hline Radionuclide & $\begin{array}{c}\mathrm{Kd} \\
(\mathrm{mL} / \mathrm{g})\end{array}$ & $\begin{array}{c}\mathrm{Kd} \\
\text { Reference } \\
\end{array}$ & $\begin{array}{l}\text { ATR Complex (Site 5) } \\
\text { Groundwater } \\
\text { Screening } \\
\text { Concentration } \\
(\mathrm{pCi} / \mathrm{L})^{\mathrm{a}} \\
\end{array}$ & $\begin{array}{l}\text { INTEC (Site 34) } \\
\text { Groundwater } \\
\text { Screening } \\
\text { Concentration } \\
(\mathrm{pCi} / \mathrm{L})^{\mathrm{a}} \\
\end{array}$ & $\begin{array}{c}\text { Federal } \\
\text { Maximum } \\
\text { Contaminant } \\
\text { Level } \\
(\mathrm{pCi} / \mathrm{L}) \\
\end{array}$ \\
\hline $\mathrm{Cm}-243$ & 4000 & Jenkins (2001) & 0 & 0 & 15 \\
\hline $\mathrm{Cm}-244$ & 4000 & Jenkins (2001) & 0 & 0 & 15 \\
\hline Co-60 & 10 & DOE-ID (1994) & 0 & 0 & 100 \\
\hline Cs-134 & 50 & DOE-ID (2006a) & 0 & 0 & 80 \\
\hline Cs-135 & 50 & DOE-ID (2006a) & 0.07 & 0.07 & 900 \\
\hline Cs-137 & 50 & DOE-ID (2006a) & 0 & 0 & 200 \\
\hline Eu-152 & 340 & Jenkins (2001) & 0 & 0 & 200 \\
\hline Eu-154 & 340 & Jenkins (2001) & 0 & 0 & 200 \\
\hline Eu-155 & 340 & Jenkins (2001) & 0 & 0 & 600 \\
\hline $\mathrm{Fe}-55$ & 220 & DOE-ID (1994) & 0 & 0 & 2,000 \\
\hline H-3 & 0 & DOE-ID (1994) & $2.8 \mathrm{E}+05$ & $6.2 \mathrm{E}+06$ & 20,000 \\
\hline Hf-182 & 450 & Jenkins (2001) & $5.9 \mathrm{E}-05$ & $5.9 \mathrm{E}-05$ & $490^{b}$ \\
\hline I-129 & 0 & DOE-ID (1994) & 537 & 537 & 1 \\
\hline Ir-192m & 91 & Jenkins (2001) & 0 & 0 & 4,807 \\
\hline $\mathrm{K}-40$ & 15 & DOE-ID (1994) & 0.02 & 0.02 & $240^{\mathrm{b}}$ \\
\hline Mo-93 & 10 & Jenkins (2001) & 364 & 427 & $469^{b}$ \\
\hline $\mathrm{Nb}-93 \mathrm{~m}$ & 100 & Jenkins (2001) & 0 & 0 & 1,000 \\
\hline Nb-94 & 100 & Jenkins (2001) & 92 & 119 & $853^{b}$ \\
\hline Ni-59 & 100 & DOE-ID (1994) & 5679 & 6091 & 300 \\
\hline $\mathrm{Ni}-63$ & 100 & DOE-ID (1994) & 0 & 0 & 50 \\
\hline Np-237 & 2 & DOE-ID (2006a) & 0.34 & 0.34 & 15 \\
\hline $\mathrm{Pa}-231$ & 550 & Jenkins (2001) & $1.1 \mathrm{E}-07$ & 2.7E-07 & 15 \\
\hline Pm-147 & 240 & Jenkins (2001) & 0 & 0 & $5,668^{\mathrm{b}}$ \\
\hline $\mathrm{Pu}-238^{\mathrm{e}}$ & 1.6 & DOE-ID (2006a) & 0.03 & 0.03 & $1.9 \mathrm{E}+05^{\mathrm{c}}$ \\
\hline Pu-239 & 22 & Jenkins (2001) & 4.0 & 4.2 & 15 \\
\hline Pu-240 & 22 & Jenkins (2001) & 1.3 & 1.5 & 15 \\
\hline $\mathrm{Pu}-241^{\mathrm{d}}$ & 2 & DOE-ID (2006a) & 0.02 & 0.02 & 15 \\
\hline $\mathrm{Pu}-242$ & 22 & Jenkins (2001) & 0 & 0 & 15 \\
\hline Re-187 & 10 & Jenkins (2001) & 21 & 21 & 9,000 \\
\hline Rh-102 & 52 & Jenkins (2001) & 0 & 0 & $573^{\mathrm{b}}$ \\
\hline Sb-125 & 50 & DOE-ID (1994) & 0 & 0 & 300 \\
\hline Se-79 & 4 & DOE-ID (1994) & 0.47 & 0.48 & $512^{\mathrm{b}}$ \\
\hline
\end{tabular}


Table 9. (continued).

\begin{tabular}{|c|c|c|c|c|c|}
\hline Radionuclide & $\begin{array}{c}\mathrm{Kd} \\
(\mathrm{mL} / \mathrm{g}) \\
\end{array}$ & $\begin{array}{c}\text { Kd } \\
\text { Reference }\end{array}$ & $\begin{array}{l}\text { ATR Complex (Site 5) } \\
\text { Groundwater } \\
\text { Screening } \\
\text { Concentration } \\
(\mathrm{pCi} / \mathrm{L})^{\mathrm{a}} \\
\end{array}$ & $\begin{array}{l}\text { INTEC (Site 34) } \\
\text { Groundwater } \\
\text { Screening } \\
\text { Concentration } \\
(\mathrm{pCi} / \mathrm{L})^{\mathrm{a}} \\
\end{array}$ & $\begin{array}{c}\text { Federal } \\
\text { Maximum } \\
\text { Contaminant } \\
\text { Level } \\
(\mathrm{pCi} / \mathrm{L}) \\
\end{array}$ \\
\hline Sm-151 & 240 & Jenkins (2001) & 0 & 0 & 1,000 \\
\hline Sn-121m & 130 & Jenkins (2001) & 0 & 0 & $6,504^{\mathrm{b}}$ \\
\hline Sn-126 & 130 & Jenkins (2001) & $2.7 \mathrm{E}-04$ & $2.9 \mathrm{E}-04$ & $310^{\mathrm{b}}$ \\
\hline $\mathrm{Sr}-90$ & 24 & DOE-ID (1994) & 0 & 0 & 8 \\
\hline Ta-180 & 220 & Jenkins (2001) & $6.7 \mathrm{E}-01$ & $6.7 \mathrm{E}-01$ & $1,757^{\mathrm{b}}$ \\
\hline Tc-99 & 0 & DOE-ID (2006a) & $6.7 E+04$ & $6.7 \mathrm{E}+04$ & 900 \\
\hline Th-228 & 100 & DOE-ID (1994) & 0 & 0 & 15 \\
\hline $\mathrm{U}-232$ & 1.6 & DOE-ID (2006a) & $2.5 \mathrm{E}-04$ & $1.3 \mathrm{E}-03$ & $6.7 \mathrm{E}+08$ \\
\hline U-233 & 1.6 & DOE-ID (2006a) & 0.02 & 0.02 & $2.9 \mathrm{E}+05$ \\
\hline U-234 & 1.6 & DOE-ID (2006a) & 0.17 & 0.17 & $1.9 \mathrm{E}+05^{\mathrm{c}}$ \\
\hline U-235 & 1.6 & DOE-ID (2006a) & 0.72 & 0.72 & 58 \\
\hline U-236 & 1.6 & DOE-ID (2006a) & 0.02 & 0.02 & 1,952 \\
\hline U-238 & 1.6 & DOE-ID (2006a) & 2258 & 2258 & $10^{c}$ \\
\hline $\mathrm{Zr}-93$ & 600 & DOE-ID (1994) & 16 & 16 & 2,000 \\
\hline
\end{tabular}

To ensure that other potentially important radionuclides were not omitted from the Phase IV analysis step, radionuclides whose Phase III peak concentration is estimated to be greater than $1 / 100^{\text {th }}$ the MCL also were retained. This adds seven additional radionuclides to be assessed, including Cl-36, Mo-93, Nb94, Np-237, Pu-239, Pu-240, and U-235. These seven additional radionuclides are shown in the unshaded, boxed cells of Table 9 . The ratio of predicted groundwater concentration to MCL for all Phase III radionuclides is shown for Sites 5 and 34 in Figures 13 and 14, respectively.

\subsection{Phase IV Results}

After the Phase III screening calculations (Table 9), six radionuclides remained with predicted peak groundwater screening concentration greater than their respective MCL. An additional seven radionuclides were retained because their peak predicted concentration to MCL ratio was greater than 0.01. Predicted peak concentrations for both candidate locations and nuclide-specific MCLs are shown in Table 10. The peak concentrations shown in Column 2 are for Site 5 and those shown in Column 4 are for Site 34. These are simulated concentrations directly below the facility and conservatively represent the highest concentrations that are predicted in the aquifer for all times. The time when the peak is expected to occur for each nuclide at Site 5 is given in Column 3 and in Column 5 for Site 34. The Federal MCL 
for each nuclide is given in Column 6. Radioactive progeny that grow in during transport are accounted for and included in the all-pathways EDE for the parent and are indicated by the nuclides in parenthesis.

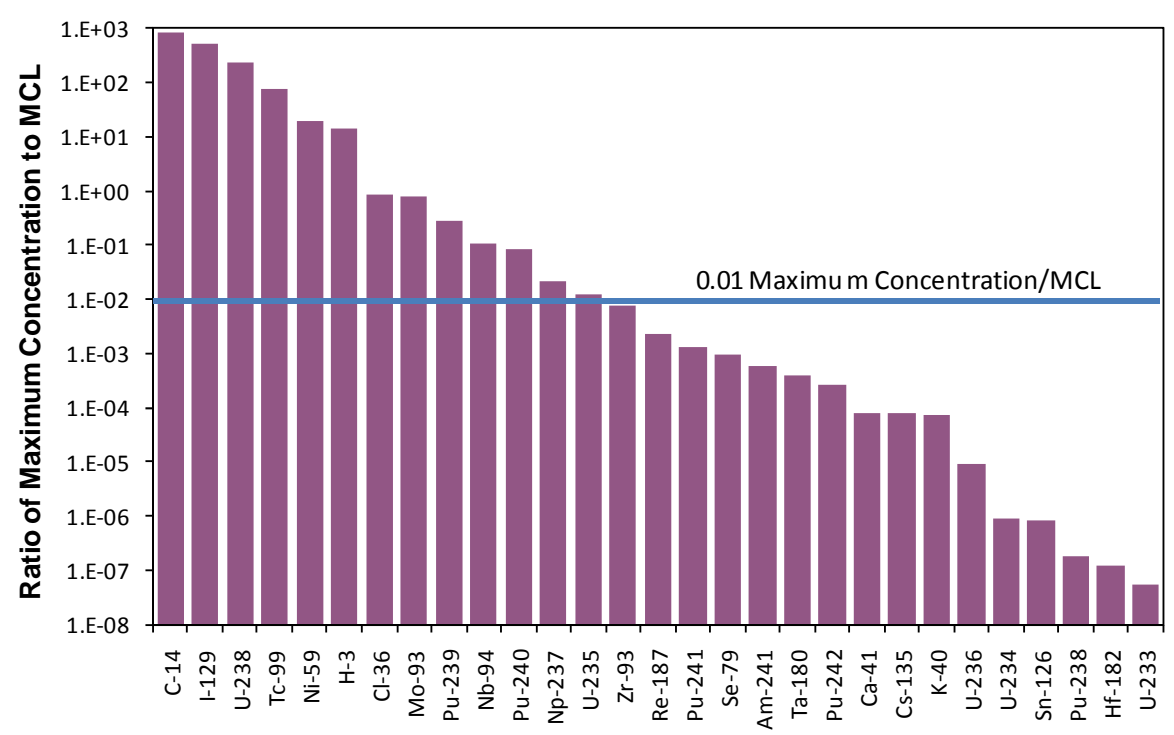

Figure 13. Ratio of predicted concentration to the maximum contaminant level for each radionuclide based on peak groundwater concentrations predicted during Phase III analysis for Site 5.

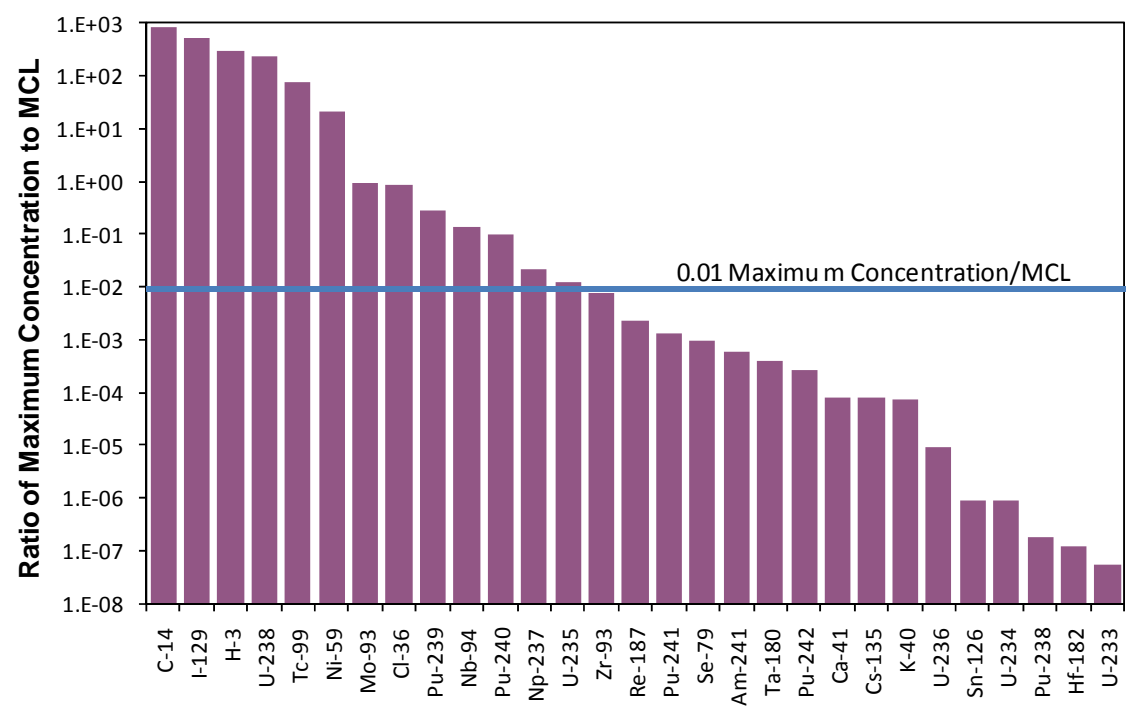

Figure 14. Ratio of predicted concentration to the maximum contaminant level for each radionuclide based on peak groundwater concentrations predicted during Phase III analysis for Site 34. 
For each radionuclide, the predicted peak concentration is less than the MCL (i.e., for C-14, the predicted peak concentration at Site 5 is $440 \mathrm{pCi} / \mathrm{L}$, and the MCL is $2,000 \mathrm{pCi} / \mathrm{L}$ ). The first nuclide predicted to reach the aquifer is tritium (H-3), which is expected to peak at $0.00077 \mathrm{pCi} / \mathrm{L}$ in about year 2,215. The MCL for tritium is $20,000 \mathrm{pCi} / \mathrm{L}$. Iodine- 129 and Tc- 99 have the highest concentrations relative to their MCLs. Peak predicted groundwater concentration for I- 129 is $20 \%$ of the MCL at Site 5 and $26 \%$ of the MCL at Site 34. Peak predicted Tc-99 concentrations are $24 \%$ of the MCL for Site 5 and $32 \%$ of the MCL for Site 34. Peak groundwater concentrations for Tc-99 and I-129 were estimated to occur about 800 and 15,000 years, respectively, after closure of the facility.

In general, predicted concentrations at Site 5 are lower than at Site 34, with each radionuclide arriving later in time. These differences occur in this analysis because sediment at Site 5 is thicker than at Site 34 .

The corresponding all-pathways EDEs are presented in Table 11 for both sites. Peak dose at Site 5 is shown in Column 2, with the corresponding time of occurrence in Column 3. The predicted peak and time of occurrence for Site 34 are given in Columns 4 and 5, respectively. All-pathway doses at both sites were less than the $25 \mathrm{mrem} /$ year all-pathways EDE dose criteria set forth in DOE Order 435.1.

The all-pathways EDE as a function of calendar year for Site 5 is shown in Figure 15 and in Figure 16 for Site 34. Radioactive progeny that grow in during transport are accounted for and included in the all-pathways EDE for the parent. At both sites, C-14 is the largest predicted dose contributor, followed by Tc-99.

The $25 \mathrm{mrem} /$ year all-pathways EDE dose criteria in DOE Order 435.1 are applied during a 1,000-year compliance time period (calendar year 2168 to 3067). The all-pathways dose can be added across all radionuclides. The peak total dose during the 1,000-year time of compliance is $0.62 \mathrm{mrem} / \mathrm{year}$ for Site 5 and $1.0 \mathrm{mrem} / \mathrm{year}$ for Site 34 . This total peak represents the cumulative dose, at that time, from all radionuclides in the groundwater $100 \mathrm{~m}$ from the downgradient facility boundary.

Table 10. Predicted peak radionuclide concentrations in groundwater and time of occurrence for Candidate Sites 5 and 34.

\begin{tabular}{|c|c|c|c|c|c|}
\hline \multirow[b]{2}{*}{$\begin{array}{l}\text { Radionuclide } \\
\text { (progeny) }\end{array}$} & \multicolumn{2}{|c|}{ Candidate Site 5} & \multicolumn{2}{|c|}{ Candidate Site 34} & \multirow[b]{2}{*}{$\begin{array}{l}\mathrm{MCL}^{\mathrm{a}} \\
(\mathrm{pCi} / \mathrm{L})\end{array}$} \\
\hline & $\begin{array}{l}\text { Peak Concentration } \\
(\mathrm{pCi} / \mathrm{L})\end{array}$ & $\begin{array}{c}\text { Calendar Year } \\
\text { Peak Occurs }\end{array}$ & $\begin{array}{c}\text { Peak Concentration } \\
(\mathrm{pCi} / \mathrm{L})\end{array}$ & $\begin{array}{l}\text { Calendar Year } \\
\text { Peak Occurs }\end{array}$ & \\
\hline C-14 & $1.48 \mathrm{E}+02$ & 5468 & $2.77 \mathrm{E}+02$ & 4018 & 2,000 \\
\hline $\mathrm{C}-136$ & $1.18 \mathrm{E}-01$ & 3918 & $1.14 \mathrm{E}-01$ & 3468 & 700 \\
\hline $\mathrm{H}-3$ & $2.27 \mathrm{E}-05$ & 2218 & 4.03E-04 & 2218 & 20,000 \\
\hline $\mathrm{I}-129$ & $1.94 \mathrm{E}-01$ & 11118 & $2.55 \mathrm{E}-01$ & 8618 & 1 \\
\hline Mo-93 & $4.35 \mathrm{E}-02$ & 21568 & $3.79 \mathrm{E}-01$ & 16068 & 469 \\
\hline $\mathrm{Nb}-94$ & $1.55 \mathrm{E}-02$ & 412068 & $9.20 \mathrm{E}-02$ & 302068 & 853 \\
\hline $\mathrm{Ni}-59$ & $5.77 \mathrm{E}+00$ & 267068 & $1.38 \mathrm{E}+01$ & 207068 & 300 \\
\hline Tc-99 & $1.08 \mathrm{E}+02$ & 3107 & $1.46 \mathrm{E}+02$ & 2793 & 900 \\
\hline Np-237 & $7.27 \mathrm{E}-04$ & 56818 & $9.47 \mathrm{E}-04$ & 41818 & 15 \\
\hline$(\mathrm{U}-233)^{\mathrm{a}}$ & $2.04 \mathrm{E}-04$ & 48818 & $1.98 \mathrm{E}-04$ & 36818 & $2.89 \mathrm{E}+05$ \\
\hline (Th-229) & $3.78 \mathrm{E}-06$ & 58818 & $3.43 \mathrm{E}-06$ & 45818 & 15 \\
\hline $\mathrm{Pu}-239$ & $3.05 \mathrm{E}-13$ & 262068 & 7.67E-11 & 222068 & 15 \\
\hline$(\mathrm{U}-235)^{\mathrm{a}}$ & $3.18 \mathrm{E}-06$ & 55818 & $3.50 \mathrm{E}-06$ & 39818 & 65 \\
\hline
\end{tabular}


Table 10. (continued).

\begin{tabular}{|c|c|c|c|c|c|}
\hline \multirow[b]{2}{*}{$\begin{array}{l}\text { Radionuclide } \\
\text { (progeny) }\end{array}$} & \multicolumn{2}{|c|}{ Candidate Site 5} & \multicolumn{2}{|c|}{ Candidate Site 34} & \multirow[b]{2}{*}{$\begin{array}{l}\mathrm{MCL}^{\mathrm{a}} \\
(\mathrm{pCi} / \mathrm{L})\end{array}$} \\
\hline & $\begin{array}{l}\text { Peak Concentration } \\
(\mathrm{pCi} / \mathrm{L})\end{array}$ & $\begin{array}{l}\text { Calendar Year } \\
\text { Peak Occurs }\end{array}$ & $\begin{array}{l}\text { Peak Concentration } \\
(\mathrm{pCi} / \mathrm{L})\end{array}$ & $\begin{array}{l}\text { Calendar Year } \\
\text { Peak Occurs }\end{array}$ & \\
\hline$(\mathrm{Pa}-231)$ & $3.36 \mathrm{E}-08$ & 92068 & $3.34 \mathrm{E}-08$ & 70818 & 15 \\
\hline (Ac-227) & $5.41 \mathrm{E}-08$ & 92068 & 5.39E-08 & 70818 & 15 \\
\hline $\mathrm{Pu}-240$ & $5.30 \mathrm{E}-16$ & 66818 & $7.00 \mathrm{E}-15$ & 66818 & 15 \\
\hline$(\mathrm{U}-236)^{\mathrm{a}}$ & $2.44 \mathrm{E}-05$ & 41818 & $2.89 \mathrm{E}-05$ & 32818 & 1941 \\
\hline (Th-232) & $9.47 \mathrm{E}-13$ & 577068 & $9.10 \mathrm{E}-13$ & 432068 & 15 \\
\hline (Ra-228) & $8.08 \mathrm{E}-13$ & 577068 & $7.77 \mathrm{E}-13$ & 437068 & 5 \\
\hline (Th-228) & $5.87 \mathrm{E}-13$ & 582068 & $5.67 \mathrm{E}-13$ & 437068 & 15 \\
\hline $\mathrm{U}-235^{\mathrm{b}}$ & $2.07 \mathrm{E}-03$ & 55818 & $2.86 \mathrm{E}-03$ & 39818 & 65 \\
\hline$(\mathrm{Pa}-231)$ & $1.61 \mathrm{E}-05$ & 92068 & $1.73 \mathrm{E}-05$ & 70818 & 15 \\
\hline (Ac-227) & $2.59 \mathrm{E}-05$ & 92068 & $2.79 \mathrm{E}-05$ & 70818 & 15 \\
\hline $\mathrm{U}-238^{\mathrm{b}}$ & $9.68 \mathrm{E}-02$ & 132068 & $9.29 \mathrm{E}-02$ & 92068 & 10 \\
\hline$(\mathrm{U}-234)^{\mathrm{a}}$ & 5.39E-01 & 92068 & $5.38 \mathrm{E}-01$ & 62818 & $1.87 \mathrm{E}+05$ \\
\hline (Th-230) & $9.72 \mathrm{E}-03$ & 372068 & $9.64 \mathrm{E}-03$ & 362068 & 15 \\
\hline (Ra-226) & $9.69 \mathrm{E}-03$ & 377068 & $9.61 \mathrm{E}-03$ & 362068 & 5 \\
\hline$(\mathrm{Pb}-210)$ & $1.59 \mathrm{E}-02$ & 367068 & $1.58 \mathrm{E}-02$ & 357068 & 2.12 \\
\hline
\end{tabular}

a. MCL for uranium isotopes converted from $30 \mu \mathrm{g} / \mathrm{L}$ mass concentration to equivalent activity concentration.

Table 11. Peak predicted all-pathways doses and time of occurrence for Candidate Sites 5 and 34.

\begin{tabular}{l|cc|cc}
\hline \multirow{2}{*}{ Radionuclide (progeny) } & \multicolumn{2}{|c|}{ Candidate Site 5 } & \multicolumn{2}{c}{ Candidate Site 34 } \\
\cline { 2 - 5 } & $\begin{array}{c}\text { Peak } \\
\text { All-Pathways } \\
\text { (mrem/year) }\end{array}$ & $\begin{array}{c}\text { Peak } \\
\text { Calendar } \\
\text { Year } \\
\text { Preak }\end{array}$ & $\begin{array}{c}\text { All-Pathways } \\
\text { Groundwater Dose } \\
\text { (mrem/year) }\end{array}$ & $\begin{array}{c}\text { Calendar } \\
\text { Year } \\
\text { Peak Occurs }\end{array}$ \\
\hline C-14 & $8.47 \mathrm{E}-01$ & 5468 & $1.58 \mathrm{E}+00$ & 4018 \\
Cl-36 & $1.22 \mathrm{E}-02$ & 3918 & $1.17 \mathrm{E}-02$ & 3468 \\
H-3 & $2.92 \mathrm{E}-09$ & 2218 & $5.20 \mathrm{E}-08$ & 2218 \\
I-129 & $1.25 \mathrm{E}-01$ & 11118 & $1.64 \mathrm{E}-01$ & 8618 \\
Mo-93 & $5.58 \mathrm{E}-04$ & 21568 & $4.86 \mathrm{E}-03$ & 16068 \\
Nb-94 & $1.14 \mathrm{E}-03$ & 412068 & $6.78 \mathrm{E}-03$ & 302068 \\
Ni-59 & $1.43 \mathrm{E}-03$ & 267068 & $3.42 \mathrm{E}-03$ & 207068 \\
Tc-99 & $6.01 \mathrm{E}-01$ & 3107 & $8.12 \mathrm{E}-01$ & 2793
\end{tabular}


Table 11. (continued).

\begin{tabular}{|c|c|c|c|c|}
\hline \multirow[b]{2}{*}{ Radionuclide (progeny) } & \multicolumn{2}{|c|}{ Candidate Site 5} & \multicolumn{2}{|c|}{ Candidate Site 34} \\
\hline & $\begin{array}{c}\text { Peak } \\
\text { All-Pathways } \\
\text { Groundwater Dose } \\
\text { (mrem/year) }^{\mathrm{a}, \mathrm{b}}\end{array}$ & $\begin{array}{c}\text { Calendar } \\
\text { Year } \\
\text { Peak Occurs } \\
\end{array}$ & $\begin{array}{c}\text { Peak } \\
\text { All-Pathways } \\
\text { Groundwater Dose } \\
\text { (mrem/year) }{ }^{\mathrm{a}, \mathrm{b}}\end{array}$ & $\begin{array}{c}\text { Calendar } \\
\text { Year } \\
\text { Peak Occurs }\end{array}$ \\
\hline Np-237 & $2.21 \mathrm{E}-04$ & 56818 & $2.89 \mathrm{E}-04$ & 41818 \\
\hline (U-233) & $3.13 \mathrm{E}-05$ & 48,818 & $3.04 \mathrm{E}-05$ & 36818 \\
\hline (Th-229) & $6.86 \mathrm{E}-06$ & 58818 & $6.23 \mathrm{E}-06$ & 45818 \\
\hline Np-237 Total ${ }^{\mathrm{c}}$ & $2.57 \mathrm{E}-04$ & 55818 & $3.23 \mathrm{E}-04$ & 41818 \\
\hline $\mathrm{Pu}-239$ & $2.17 \mathrm{E}-13$ & 262068 & $5.44 \mathrm{E}-11$ & 222068 \\
\hline (U-235) & 4.47E-07 & 55818 & 4.93E-07 & 39818 \\
\hline$(\mathrm{Pa}-231)$ & $4.55 \mathrm{E}-08$ & 92068 & $4.53 \mathrm{E}-08$ & 70818 \\
\hline$(\mathrm{Ac}-227)$ & $6.76 \mathrm{E}-08$ & 92068 & $6.73 \mathrm{E}-08$ & 70818 \\
\hline $\mathrm{Pu}-239$ Total $^{\mathrm{c}}$ & $5.22 \mathrm{E}-07$ & 59818 & $5.59 \mathrm{E}-07$ & 41818 \\
\hline $\mathrm{Pu}-240$ & $3.76 \mathrm{E}-16$ & 66818 & $4.97 \mathrm{E}-15$ & 66818 \\
\hline (U-236) & $3.42 \mathrm{E}-06$ & 41818 & 4.06E-06 & 32818 \\
\hline (Th-232) & $6.19 \mathrm{E}-13$ & 577068 & $5.94 \mathrm{E}-13$ & 432068 \\
\hline (Ra-228) & $1.67 \mathrm{E}-12$ & 577068 & $1.61 \mathrm{E}-12$ & 437068 \\
\hline (Th-228) & $2.37 \mathrm{E}-13$ & 582068 & $2.29 \mathrm{E}-13$ & 437068 \\
\hline $\mathrm{Pu}-240$ Total $^{\mathrm{c}}$ & $3.42 \mathrm{E}-06$ & 41818 & $4.06 \mathrm{E}-06$ & 32818 \\
\hline U-235 & 4.47E-07 & 55818 & $4.94 \mathrm{E}-07$ & 39818 \\
\hline$(\mathrm{Pa}-231)$ & $4.55 \mathrm{E}-08$ & 92068 & $4.53 \mathrm{E}-08$ & 70818 \\
\hline$($ Ac-227) & $6.76 \mathrm{E}-08$ & 92068 & $6.73 \mathrm{E}-08$ & 70818 \\
\hline $\mathrm{U}-235$ Total $^{\mathrm{c}}$ & $5.22 \mathrm{E}-07$ & 59818 & $5.60 \mathrm{E}-07$ & 41818 \\
\hline $\mathrm{U}-238$ & $1.40 \mathrm{E}-02$ & 132068 & $1.34 \mathrm{E}-02$ & 92068 \\
\hline (U-234) & 7.99E-02 & 92068 & 7.97E-02 & 62818 \\
\hline (Th-230) & $5.89 \mathrm{E}-03$ & 372068 & $5.83 \mathrm{E}-03$ & 362068 \\
\hline (Ra-226) & $8.04 \mathrm{E}-03$ & 377068 & 7.97E-03 & 362068 \\
\hline$(\mathrm{Pb}-210)$ & 6.49E-02 & 367068 & $6.43 \mathrm{E}-02$ & 357068 \\
\hline U-238 Total $^{\mathrm{c}}$ & $1.64 \mathrm{E}-01$ & 312068 & $1.62 \mathrm{E}-01$ & 297068 \\
\hline Total & $8.76 \mathrm{E}-01$ & 5518 & $1.61 \mathrm{E}+00$ & 4018 \\
\hline
\end{tabular}




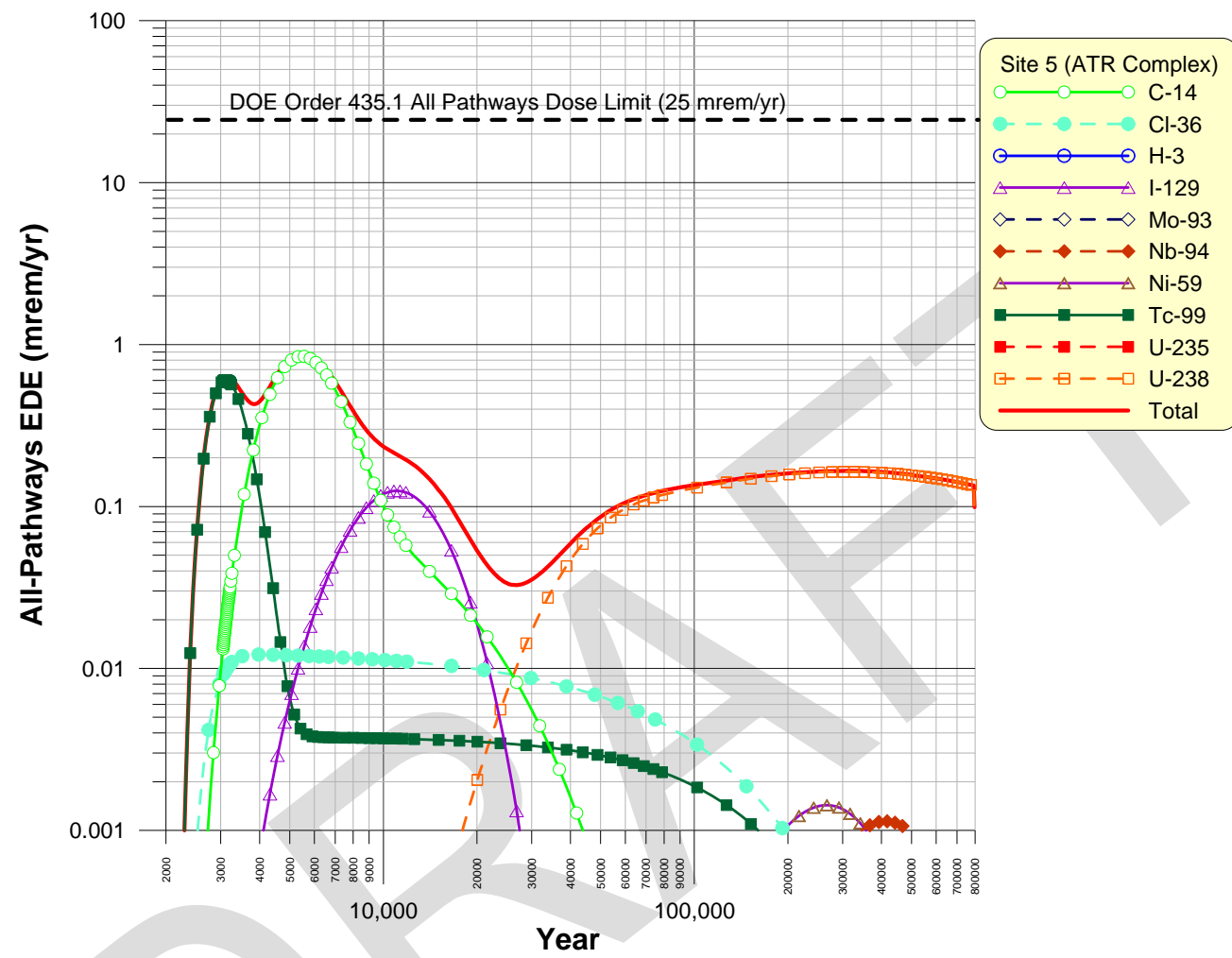

Figure 15. All-pathways EDE as a function of calendar year for Site 5. Pu-239, Pu-240, and Np-237 are not shown because their doses are less than $0.001 \mathrm{mrem} / \mathrm{year}$. The dashed line is the $25 \mathrm{mrem} / \mathrm{year}$ limit imposed by DOE Order 435.1 . 


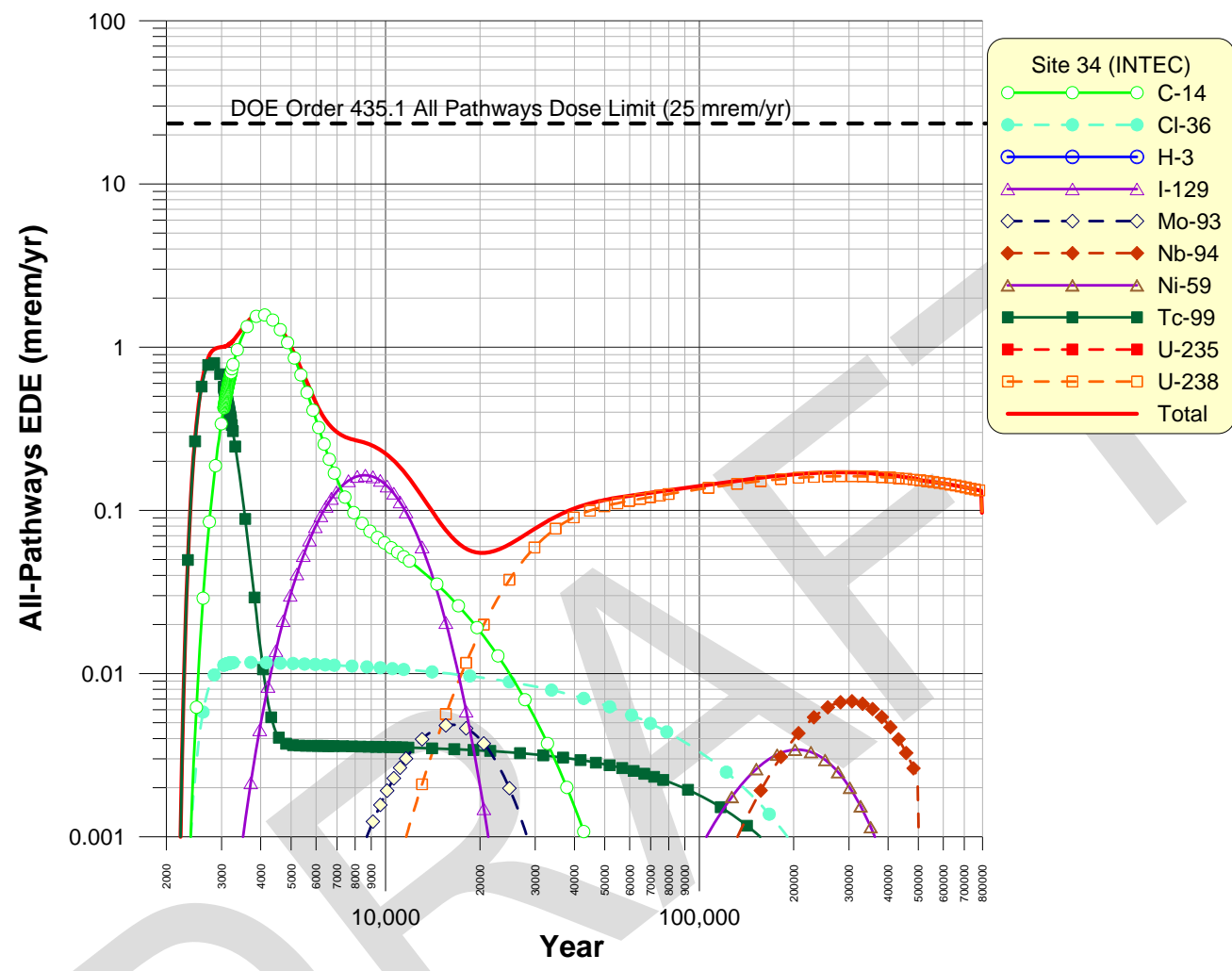

Figure 16. All-pathways EDE as a function of calendar year for Site 34. Pu-239, Pu-240, and Np-237 are not shown because their doses are less than $0.001 \mathrm{mrem} / \mathrm{year}$. The dashed line is the $25 \mathrm{mrem} / \mathrm{year}$ limit imposed by DOE Order 435.1.

\section{SENSITIVITY AND UNCERTAINTY}

The purpose of this groundwater impacts analysis was to provide conservative estimates of individual radionuclide concentrations and combined all-pathways EDE while incorporating site-specific conditions allowing distinction of behavioral responses for a facility sited at either of two candidate locations. This analysis considered orientation of the facility. The facility design includes concrete vaults supported by concrete base sections placed on top of a gravel base layer and covered with concrete plugs. The design allows for water to infiltrate between the vaults without ponding water within the vaults. Final facility closure will include a protective cover designed to minimize infiltration into the vaults while reducing leachate generation and contamination transport and to provide a barrier against intrusion and erosion. The analysis was based on the average inventory of RH-LLW expected to be generated by operations at MFC, ATR Complex, and NRF. Primary flow and transport processes included in the evaluation consisted of advection, dispersion, sorption, radioactive decay and the generation of progeny in the vadose zone and aquifer. The model was parameterized using data made available through historical investigations at INL. Data used included infiltration rates, geostratigraphy; aquifer velocity, and nuclidespecific sorption to the sand/gravel base layer, alluvium, sedimentary interbeds, and basalts. 
As explained below, not all aspects of facility design were included in the prediction of groundwater concentration. In selecting processes to include and parameters for use, assumptions were made. The groundwater concentrations and doses for both locations given in Tables 10 and 11 and shown in Figures 15 and 16 incorporated the following conservative assumptions:

- The engineered cover was neglected. Engineered covers are designed to reduce infiltration through disposal facilities, resulting in less water contacting the waste during the effective cover lifetime. Not accounting for the cover means higher transport rates through the vadose zone and correspondingly less radioactive decay. Predicted concentrations and doses would be lower if the cover was accounted for and the peak concentration would occur later in time.

- Sorption onto resins and cement components of the vault were neglected. Resins are designed to chemically extract radionuclides from water, and to retain them on the resins. Retention on resins reduces the amount that can be in the water and thus reduces concentrations and doses. It also allows radioactive decay to occur prior to significant mobilization. Not accounting for sorption onto resins and cement is equivalent to assuming those nuclides are free to move with groundwater through the vault region. Predicted concentrations and doses would be reduced significantly if sorption was considered and the peak predicted concentrations would occur later in time.

- Activated metals were assumed to corrode at rates representative of high salinity environments. In order to be transported in water, the activated metals must first corrode. Corrosion rates are higher in saline environments compared to rates that would be measured in soils. Corrosion rates for metals in contact with cement are lower yet. Predicted concentrations and doses would be lower than shown in the tables and figures here if lower corrosion rates had been used and the predicted peak concentration would occur later in time.

- Corrosion of the steel liners containing the waste was neglected. Waste will be transferred from the generators at INL to the remote-handled LLW disposal facility in steel containers. These containers are placed into the concrete vaults by carefully lowering them using a crane. In order for the nuclides contained in the steel liners to migrate into the vault environment, water must first enter the liner, and then be transported from the liner. For water to enter the carbon and stainless steel liners, they must first corrode. By neglecting the time necessary for corrosion to occur, the predicted concentrations and doses are conservative. Including the protection offered by the steel containers would further reduce predicted concentrations and doses and would shift the time of peak dose out further in time.

- All radionuclides were assumed to remain in the aqueous phase. Thirteen of the radionuclides in the inventory (see Table 1) are potentially volatile radionuclides: Ar-37, Ar-39, Ar-42, C-14, H-3, I-129, I-131, I-132, I-133, Kr-81, Kr-85, Xe-131m, and Xe-133 (ECAR-1370). Partitioning into the gasphase would reduce the inventory transported to the aquifer. In making the assumption that the entire inventory remains in the aqueous phase, the fraction that would volatilize is assumed to contribute to the groundwater pathway. Thus, not accounting for phase-partitioning provides a more conservative estimate of groundwater concentrations and doses.

- Concentrations were reported $100 \mathrm{~m}(\sim 330 \mathrm{ft})$ downgradient of the facility boundary. The regulations require the all-pathways EDE to be less than $25 \mathrm{mrem}$ at that distance. Dilution and dispersion in the aquifer downgradient of that location would lower both concentrations and doses. The distance is used by DOE O 435.1 because it is unlikely that someone would drill a water supply well closer than $100 \mathrm{~m}$ from the engineered cover. It is more likely that a water supply well would be placed further from the engineered barrier. As a result, the reported concentrations and doses are conservative.

The conservative assumptions discussed above were made to balance uncertainty introduced through natural heterogeneity and in the operational processes that will be generating RH-LLW at INL throughout the next 50-years. Previous performance assessments conducted at INL (DOE-ID 2007b; DOE-ID 2010) have shown that the parameters having the greatest influence on model predicted concentrations and 
resultant doses are net sorption, infiltration rate, aquifer velocity, and inventory. These are discussed below::

- Net sorption. In this flow system, the net sorption is determined by sorption onto resins (resin waste forms only), cement vault components, sand/gravel base layer beneath the vaults, the alluvium above the first basalt contact, and sedimentary interbeds. Basalts are not included because sorption on basalts is minimal and transit time through the basalts is essentially instantaneous. Sorption to the cement will greatly retard the migration of most cations, but it has less potential to retard the migration of most anions (i.e., I-129 and Tc-99). Sorption in the vadose zone is determined by the distribution coefficient or $\mathrm{K}_{\mathrm{d}}$, bulk density, and moisture content at a given hydraulic conductivity. The sediment distribution at both candidate sites is relatively well known, and the effect of bulk density is counter-balanced within the expected range of moisture content. Therefore, the primary predictive uncertainty is introduced by 1) not accounting for sorption to the resins, and 2) natural variability in sediment sorption values for specific radionuclides.

- Infiltration rate. After the 50-year operational period, an infiltration reducing engineered barrier will be placed over the facility. This engineered cover is expected to maintain hydraulic effectiveness for several hundred years. As the vaults and cover degrade, the infiltration rate through the vaults is expected to increase and slowly re-equilibrate to the natural background rate measured across the INL. Infiltration reducing barriers have been designed for waste disposal facilities at INL (DOE-ID 2007b; DOE-ID 2010). These covers are expected to reduce the infiltration rates to $0.01 \mathrm{~cm} / \mathrm{yr}$ (ICDF) and $0.1 \mathrm{~cm} /$ year (RWMC) during the first 500 year period following facility closure, with the infiltration rate returning to $0.1 \mathrm{~cm} /$ yr during the $500-1,000$ year period post-closure. During the first 1,000 years, the average infiltration rate is dominated by the engineered cover and is a maximum of $0.55 \mathrm{~cm} /$ year for the two cover designs. Over longer periods, the average infiltration rate becomes dominated by the assumed average background rate of $0.1 \mathrm{~cm} /$ year. For example, it is equal to $0.96 \mathrm{~cm} /$ year over a 11,000 year period. Over the very long time-periods of interest to the RH-LLW disposal facility the assumed background infiltration rate will eventually become dominant relative to the engineered barrier. While neglecting the effectiveness of the engineered barrier is conservative, the larger uncertainty is associated with the background infiltration rate. However, this rate is constrained by the topology of the engineered cover, materials used in the cover, and by the climate of the INL.

- Aquifer velocity. Dilution in the aquifer is controlled by the flux of radionuclides into the aquifer, the Darcy velocity in the aquifer underlying the disposal facility, and the amount of hydrodynamic dispersion assumed in the model. The aquifer velocity is spatially variable underlying INL and was assumed to be site specific in the analysis of groundwater impacts at both candidate sites. Aquifer velocity near the two candidate sites, based on the calibrated sub-regional scale groundwater model (DOE-ID 2008), ranges from $15 \mathrm{~m} /$ year to $25 \mathrm{~m} /$ year.

- Inventory. The total inventory shown in Table 1 was derived from analyses provided by the waste generators (ECAR-851, ECAR-854, ECAR-904, ECAR-967, NRF 2011). It represents the best estimate of existing inventory and inventory expected to be generated over the next 50 years. Best estimate waste generation rates are based on previous generation rates over the past several years depending on the waste form and generator, or projected operations as is the case for NRF. In addition to computing the best estimate inventory, each of the generators provided either 1) a minimum and maximum inventory, or 2) a reasonable uncertainty fraction.

\subsection{Parametric Uncertainty Analysis}

To address uncertainty and variability in model input parameters, a parametric uncertainty analysis was performed. A parametric uncertainty analysis quantifies the variability in model output that results from variability in the model input parameters. It provides a measure of the precision of the model and 
cannot address the overall accuracy of the predictions. Numerous synonyms exist in the literature for this type of analysis, including error propagation (Gardner et al. 1980), impression analysis (Schwarz and Hoffman 1981), and statistical sensitivity analysis (Shaeffer 1980). The terminology adopted by Hoffman and Gardner (1983) is used in this document. As defined in Hoffman and Gardner (1983), a parametric uncertainty analysis is applicable when the structure of the model is relatively unbiased.

Parametric uncertainty is evaluated using a Monte Carlo simulation combined with simple random sampling techniques. Uncertainty is expressed in terms of a probability density function of the output variable. Parametric uncertainty analysis uses an estimated frequency distribution of values for each model parameter considered to be uncertain and produces a frequency distribution of model predictions. In a Monte Carlo simulation, parameter values are randomly sampled from distributions developed by the analyst. The model is then run and the output variable stored. The process is repeated for multiple model realizations (typically greater than 100), resulting in an empirical distribution of the output variable.

\subsubsection{Parameter Distributions}

In practice, parameter values are often inferred from limited measured data, derived from a combination of site-specific measurements and information and literature values. The choice of a deterministic parameter value or its distribution is ultimately determined by the judgment of the analyst and is considered to have an element of subjectivity. A distribution selected in this manner is essentially a statement of the analyst's belief that the parameter's true but unknown value lies within the stated distribution.

Uncertainty distributions were developed for parameters observed to have the greatest influence on model predicted concentrations and resultant doses. These include sorption coefficients (Kd values), infiltration rate, aquifer velocity, and radionuclide inventory. All other parameters were unchanged from those used in the Phase IV analysis. The infiltration rate is assumed to be similar at both Candidate Sites, and a single distribution was developed. Similarly, the variation in aquifer velocity was applied the same distribution at Candidate Sites 5 and 34. In contrast, sorption coefficients vary with each radionuclide and are different for the resins, alluvium, and sedimentary interbed materials. This introduces a very large parameter set for sorption coefficients if all radionuclides are considered in the sensitivity analysis. Therefore, the sensitivity analysis considers only the primary radionuclides C-14, I-129 and Tc-99 in the parametric sensitivity analysis.

Only radionuclides whose predicted concentrations were a large fraction of the MCL, or were primary dose contributors were included in the parametric uncertainty analysis. Phase IV results show predicted concentrations were less than $1 / 100^{\text {th }}(0.01)$ of their respective MCL for all radionuclides with the exception of C-14, I-129, Tc-99 and Ni-59 (see Figures 17 and 18). The predicted Ni-59 concentration was 0.019 times its MCL at Site 5 and 0.046 times the MCL at Site 34. As for dose, only C-14 and Tc-99 had doses greater than $1 / 100^{\text {th }}(0.01)$ the $25 \mathrm{mrem} / \mathrm{yr}$ dose limit (see Figures 19 and 20). The results suggest that the RH-LLW waste inventory could increase for all radionuclides other than C-14, I-129 and Tc-99 by as much as several orders of magnitude (depending on the nuclide) and still meet regulatory requirements and performance measures. 


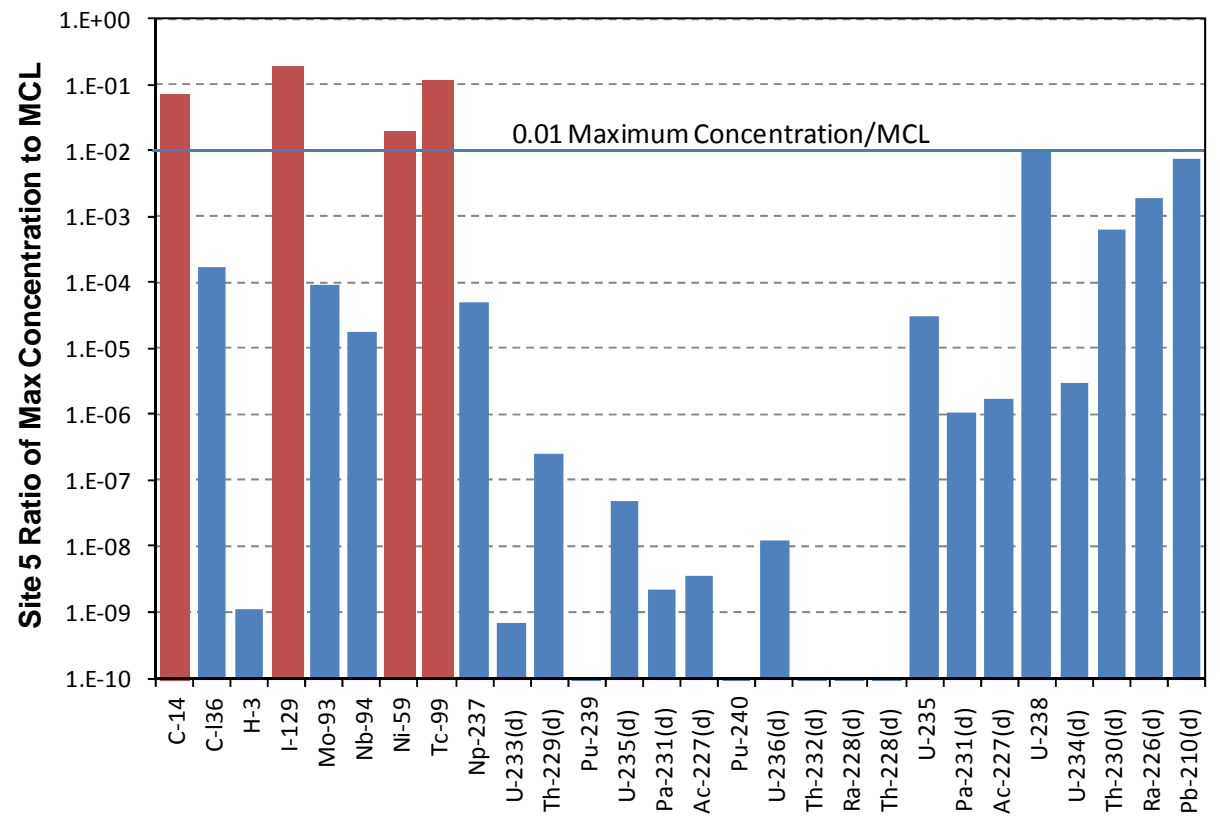

Figure 17. Ratio of maximum predicted concentration to the maximum contaminant level for each radionuclide based on peak groundwater concentrations predicted during Phase IV analysis for Site 5. Radionuclides with a ratio above 0.01 (C-14, I-129, Tc-99 and Ni-59) are shown in red. 


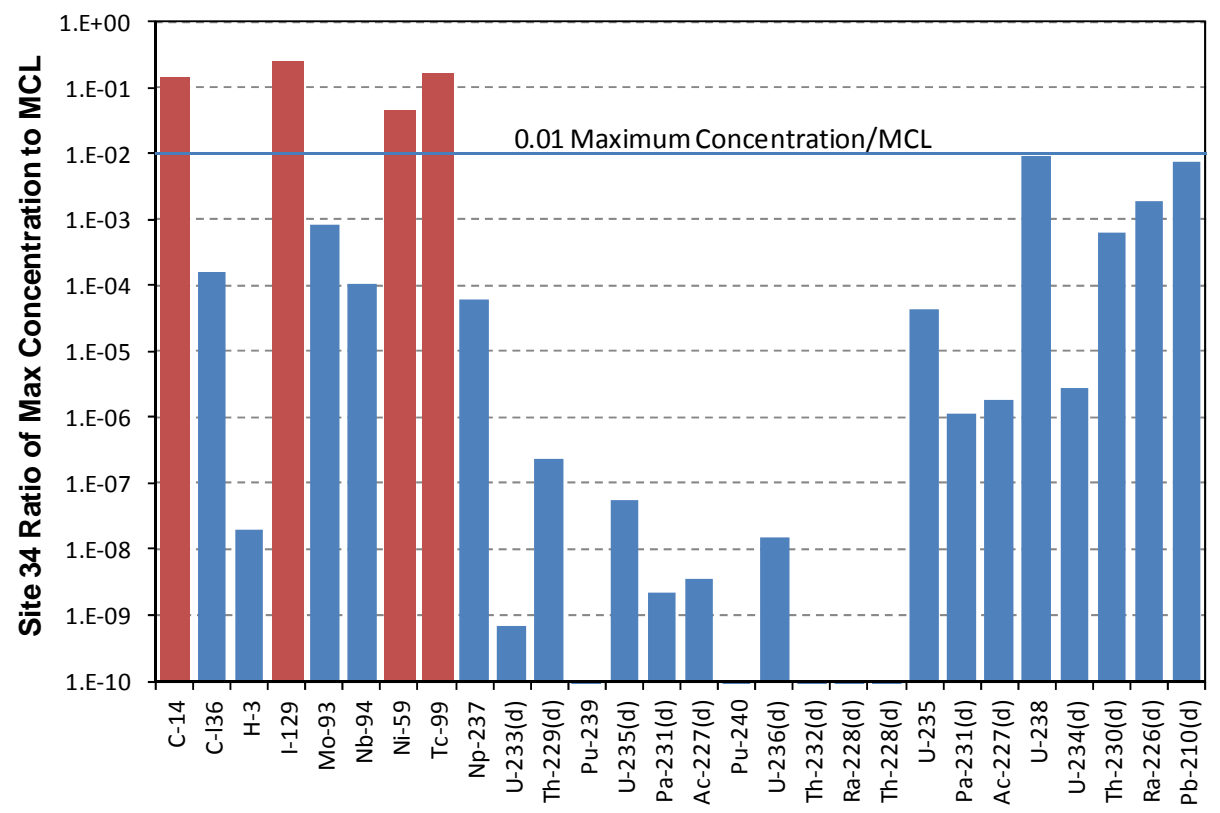

Figure 18. Ratio of maximum predicted concentration to the maximum contaminant level for each radionuclide based on peak groundwater concentrations predicted during Phase IV analysis for Site 34. Radionuclides with a ratio above 0.01 (C-14, I-129, Tc-99 and Ni-59) are shown in red. 


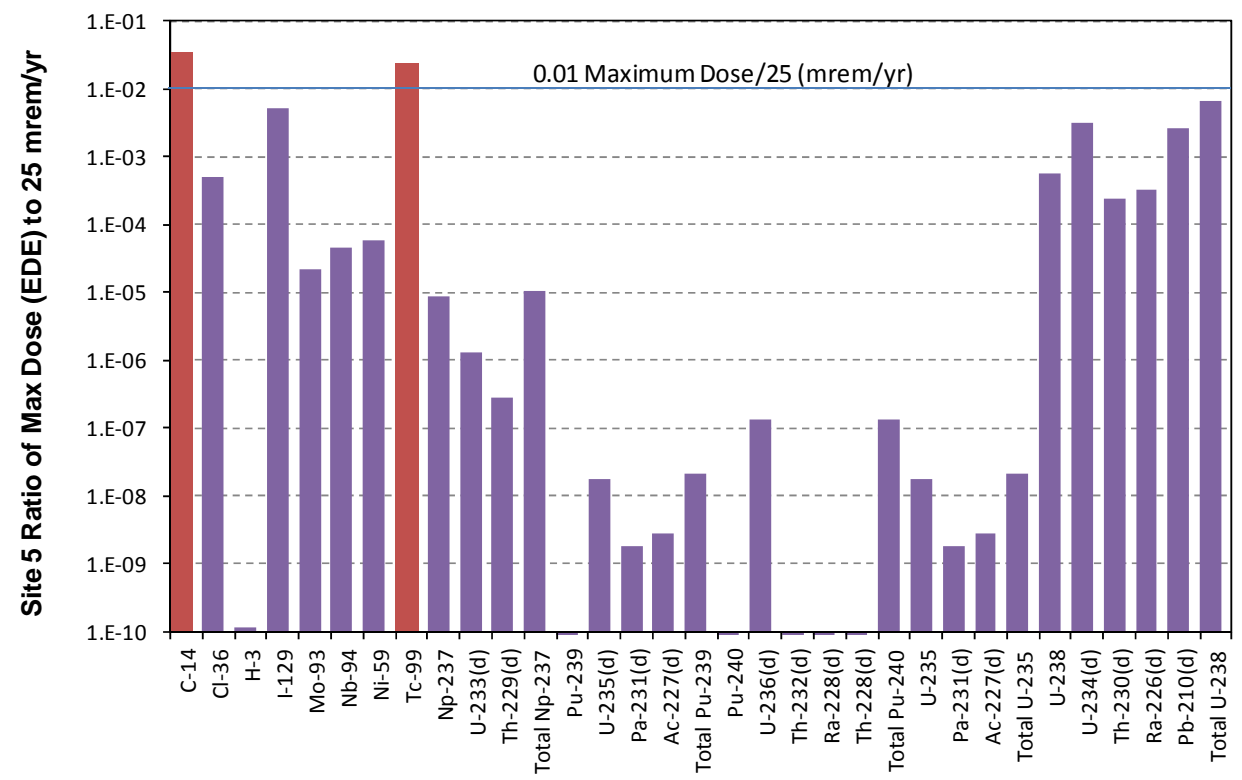

Figure 19. Ratio of peak dose to the $25 \mathrm{mrem} / \mathrm{yr}$ limit for each radionuclide based on peak groundwater all-pathways EDE predicted for the Phase IV analysis for Site 5. Radionuclides with a ratio above 0.01 (C-14 and Tc-99) are shown in red. 


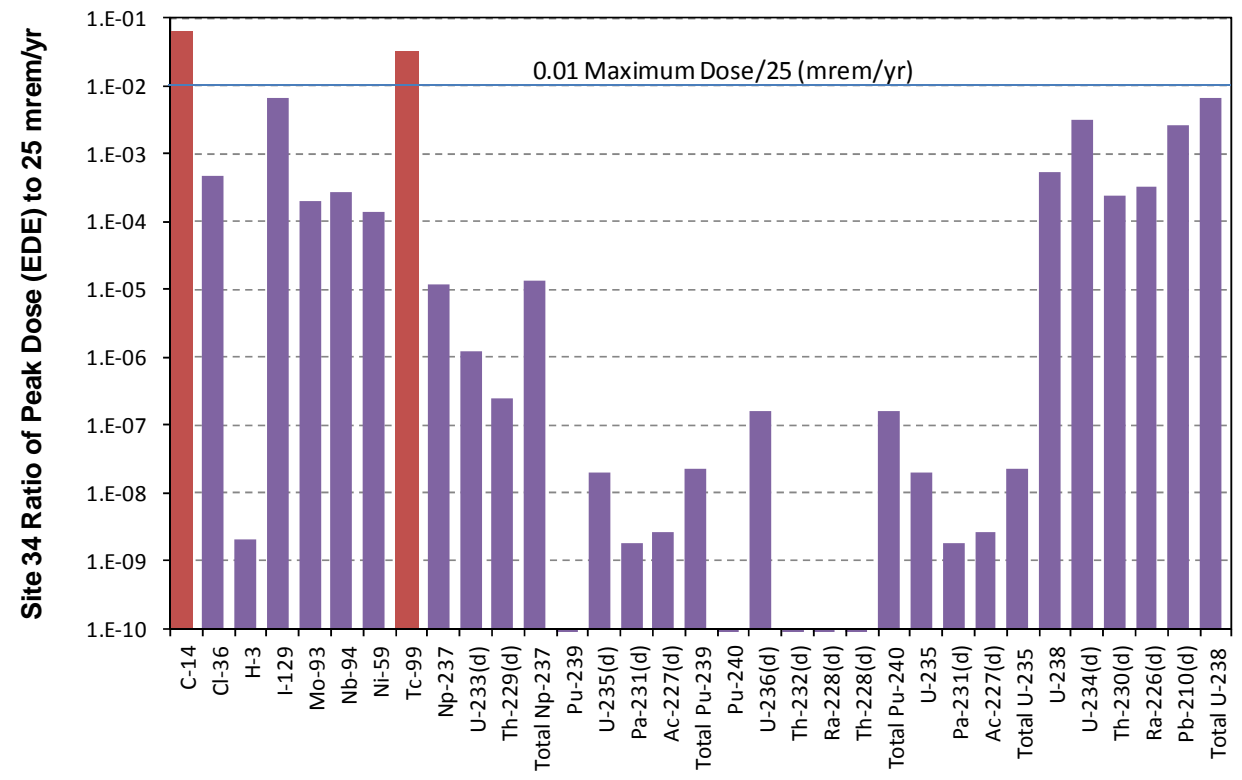

Figure 20. Ratio of peak dose to the $25 \mathrm{mrem} / \mathrm{yr}$ limit for each radionuclide based on peak groundwater all-pathways EDE predicted for the Phase IV analysis for Site 34. Radionuclides with a ratio above 0.01 (C-14 and Tc-99) are shown in red.

\subsubsection{Distribution Coefficients}

Distributions of $\mathrm{K}_{\mathrm{d}}$ values were assumed to be uncertain parameters for the resins, the cementimpacted alluvium, and vadose zone interbeds. The sorption coefficient in unsaturated basalt and the aquifer was assumed to be zero for all radionuclides. Ranges of $K_{d}$ values for the resins, alluvium and interbeds were provided in INL (2011) for the radionuclides considered.

To represent natural geologic heterogeneity, a log-normal distribution was used. It is parameterized with a generic distribution was assigned to all radionuclide $\mathrm{K}_{\mathrm{d}}$ values in this uncertainty assessment. The generic distribution was log-normally distributed, having a geometric mean equal to the base-case $\mathrm{K}_{\mathrm{d}}$ value and a geometric standard deviation of 2 . Figure 21 shows the cumulative probability function for a lognormal distribution with a geometric mean of 1.0 and a geometric standard deviation of 2.0. The cumulative probability function is given by 


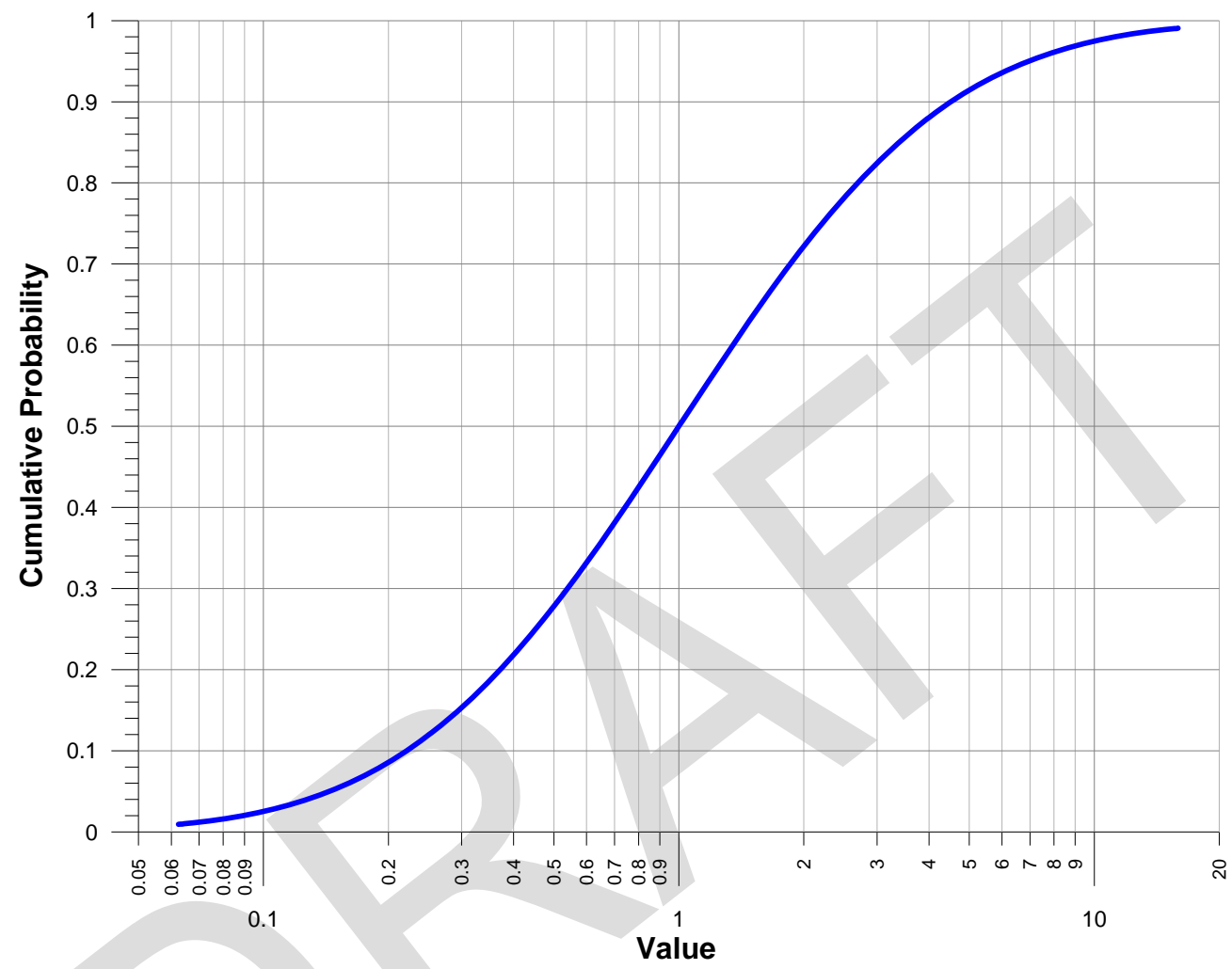

Figure 21. Cumulative probability function for a lognormal distribution having a geometric mean of 1.0 and a geometric standard deviation of 2.0 . About $90 \%$ of the distribution falls within an order of magnitude of the geometric mean value.

The lognormal distribution having these parameters will have a 95th to 5th percentile ratio of about an order of magnitude. This distribution provides a full sampling of the range of possible $\mathrm{K}_{\mathrm{d}}$ values when their estimated minimum and maximum value may span several orders of magnitude.

| To estimate a geometric standard deviation from the data provided by INL (2011€), it was assumed that the minimum and maximum value represent the 1 st and 99 th percentile of a lognormal distribution. The geometric standard deviation is then given by

where $t=$ the two-tailed $t$ statistic for $n=\infty$ and $\alpha=0.01(t=2.576)$. The geometric mean value in all cases was the deterministic base case value.

The $K_{d}$ value for resins was element-independent and the deterministic value was selected as the geometric mean. The most likely resin $\mathrm{K}_{d}$ values ranged from 9 to $13 \mathrm{~mL} / \mathrm{g}$ (INL 2011c, Section 3.1.4). Assuming a lognormal distribution where the geometric standard deviation is defined by Equation 42, a minimum value is 0.7 and a maximum value of 13 yields a geometric standard deviation of 1.76. Therefore, the resin $\mathrm{K}_{\mathrm{d}}$ values were assigned a lognormal distribution having a geometric mean of 
$6.0 \mathrm{~mL} / \mathrm{g}$ and a geometric standard deviation of 1.76 . Because the maximum value was only a factor of 2 greater than the base-case value, the distribution was truncated at a maximum value of $13 \mathrm{~mL} / \mathrm{g}$. The $\mathrm{K}_{\mathrm{d}}$ values were correlated across all elements (i.e., the resin $\mathrm{K}_{\mathrm{d}}$ was sampled once on each Monte Carlo realization).

Similarly, the $\mathrm{K}_{\mathrm{d}}$ for alluvium and sedimentary interbeds were assigned a lognormal distribution. The alluvium was assumed to be impacted by leachate from the cement vaults. This results in a value lower than for natural alluvial sediments. To parameterize the alluvium $\mathrm{K}_{\mathrm{d}}$, a geometric mean of $0.3 \mathrm{~mL} / \mathrm{g}$ and a geometric standard deviation of 1.55 was used to represent I-129, corresponding values for Tc-99 were 0.01 and 2.78 , and for C-14, the geometric mean was assigned a value of $2 \mathrm{~mL} / \mathrm{g}$ with a geometric standard deviation of 1.83 .

\subsubsection{Infiltration Rates}

As previously discussed, the Phase IV analysis did not include the effects of a cover and used a constant infiltration rate of $1 \mathrm{~cm} /$ year which is the background infiltration rate at the INL soils. Because this value is applied for very long timeframes, a greater uncertainty band was applied.

A singular value was used to represent infiltration at both candidate sites. The triangular distribution is typically used as a subjective description of a population for which there is only limited sample data, and especially in cases where the relationship between variables is known but data is scarce. It is based on knowledge of the minimum and maximum and a modal value. An example triangular distribution is shown in Figure 22. A factor of four uncertainty represented by a triangular distribution was assumed for the background infiltration rate, which encompasses the range of background values provided by Cecil et al. (1992) and provides a wider range of possible values. This sets the upper value in the triangular distribution to $4 \mathrm{~cm} / \mathrm{yr}$ and the lower value to $0.25 \mathrm{~cm} / \mathrm{yr}$.

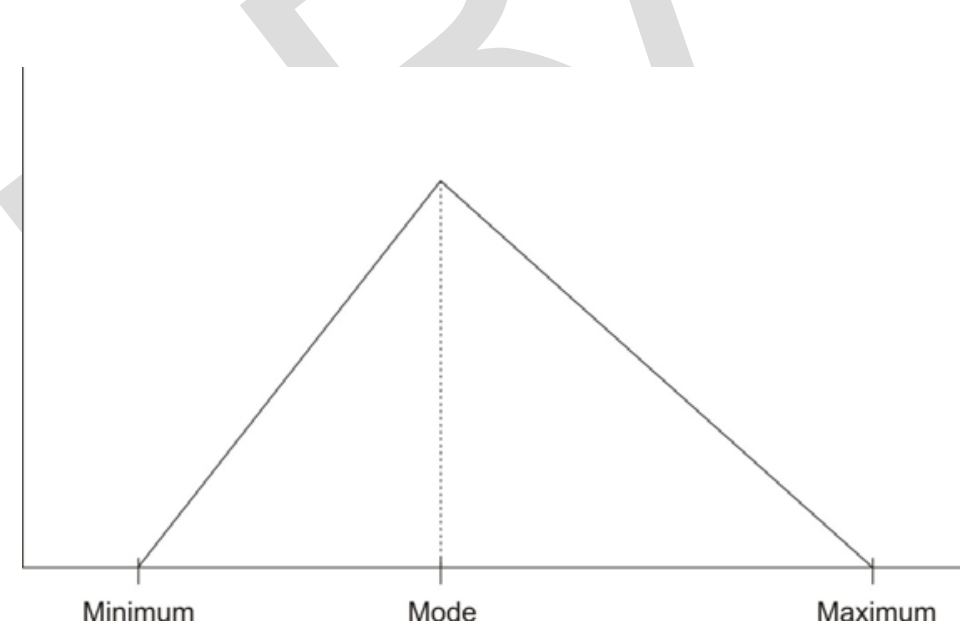

Figure 22. Typical probability density function for a triangular distribution showing the minimum (upper limit), mode (mean or central value) and maximum (upper limit).

\subsubsection{Aquifer Velocity}

The Darcy velocities used in the Phase IV analysis were $21 \mathrm{~m} / \mathrm{yr}$ and $21.9 \mathrm{~m} / \mathrm{yr}$ for Sites 5 and 34 respectively. For the uncertainty analysis, a single triangular distribution for aquifer velocity was used for 
both sites that encompassed the range of values from both sites based on velocities from DOE-ID (2008) ( 15 to $25 \mathrm{~m} /$ year) and had a mode $(20 \mathrm{~m} /$ year) close to the base case values from both sites.

\subsubsection{Inventory Scaling Factor}

Distributions for inventory scaling factors were determined from data supplied by the waste generators and varied by radionuclide and waste form. The estimated inventory is simply the scaling factor multiplied by the base-case (deterministic) inventory. All inventory scaling factor distributions were triangular distributions with a mode value of 1.0. The mode is equal to the base-case inventory for each waste form and generator. The minimum (lower limit) and maximum (upper limit) scaling factors were estimated from data supplied by the waste generators as follows (see Table 12 for references):

- $\quad$ NRF activated metals: minimum and maximum values were estimated by NRF for each of the 50 years of projected disposal. The minimum values ranged from 0.35 to 0.7 and the maximum values ranged from 1.25 to 1.5 . The minimum and maximum scaling factors for the distribution were the smallest minimum value (0.35) and the largest maximum value (1.5).

- NRF resins: minimum and maximum scaling factors were assigned 0.25 and 10 respectively based on the minimum and maximum resin concentrations supplied by NRF.

- NRF surface contamination: minimum and maximum scaling factors were assumed to be the same as NRF activated metals since surface contamination is supplied as a fraction of the activated metal activity.

- $\quad$ ATR activated metals: minimum and maximum scaling factors assumed to be the same as NRF activated metals.

- $\quad$ ATR resins: minimum and maximum of 0.9 and 1.1 were assumed. Ten percent is approximately equal to one-half the standard deviation of the three highest activity containers.

- MFC activated metals: minimum and maximum values of 0.75 and 1.25 were supplied by MFC for the majority of legacy activated metal waste containers.

- MFC debris and surface contamination: minimum and maximum values for surface contamination were assumed to be the same as MFC activated metals $(0.75,1.25)$ since surface contamination is supplied as a fraction of the activated metal activity. The same values were applied to the debris waste. The best-estimate inventory for future generation surface contamination and debris was also increased by $25 \%$ to account for uncertainties in future work and waste generation activity.

\subsubsection{Summary of Parameter Distributions}

Parameter distributions used in the uncertainty analysis are presented in Table 12. The input parameters used for the deterministic base-case (Phase IV) analysis were generally the mode or central value for most parameter distributions.

Table 12. Parameter distributions used in the parameter uncertainty analysis.

\begin{tabular}{lll}
\hline \multicolumn{1}{c}{ Parameter } & \multicolumn{1}{c}{ Statistical Distribution } & \multicolumn{1}{c}{ Comments/Reference } \\
\hline Resin $\mathrm{K}_{\mathrm{d}}$ for all radionuclides & \multicolumn{1}{c}{ Distribution Coefficients } & \\
$\begin{array}{l}\text { Iodine } \mathrm{K}_{\mathrm{d}}(\mathrm{mL} / \mathrm{g}), \\
\text { cement-impacted alluvium }\end{array}$ & $\begin{array}{l}\text { Lognormal: GM 0.3 and GSD } \\
1.55\end{array}$ & $\begin{array}{l}\text { GM is the deterministic value, GSD is } \\
\text { assumed. } \\
\text { based on the range of } \mathrm{K}_{\mathrm{d}} \text { values } \\
\text { reported in INL (2011) }\end{array}$
\end{tabular}




\begin{tabular}{|c|c|c|}
\hline Parameter & Statistical Distribution & Comments/Reference \\
\hline $\begin{array}{l}\text { Iodine } \mathrm{K}_{\mathrm{d}}(\mathrm{mL} / \mathrm{g}), \\
\text { cement-impacted sand/gravel base } \\
\text { layer }\end{array}$ & No distribution, $\mathrm{K}_{\mathrm{d}}=0$ & $\begin{array}{l}\text { Deterministic value is zero; no } \\
\text { distribution assumed. }\end{array}$ \\
\hline Iodine $\mathrm{K}_{\mathrm{d}}(\mathrm{mL} / \mathrm{g})$, interbed & Lognormal: GM 3.0 and GSD 2.0 & $\begin{array}{l}\text { GM is the deterministic value, GSD is } \\
\text { based on the range of } K_{d} \text { values } \\
\text { reported in INL ( } 2011)\end{array}$ \\
\hline $\begin{array}{l}\text { Technetium } \mathrm{K}_{\mathrm{d}}(\mathrm{mL} / \mathrm{g}) \\
\text { cement-impacted alluvium }\end{array}$ & $\begin{array}{l}\text { Lognormal: GM } 0.01 \text { and GSD } \\
2.78\end{array}$ & $\begin{array}{l}\mathrm{GM} \text { is the deterministic value, GSD is } \\
\text { based on the range of } \mathrm{K}_{\mathrm{d}} \text { values } \\
\text { reported in INL (2011). }\end{array}$ \\
\hline $\begin{array}{l}\text { Technetium } \mathrm{K}_{\mathrm{d}}(\mathrm{mL} / \mathrm{g}) \text {, } \\
\text { cement-impacted sand/gravel base } \\
\text { layer }\end{array}$ & No distribution, $\mathrm{K}_{\mathrm{d}}=0$ & $\begin{array}{l}\text { Deterministic value is zero; no } \\
\text { distribution assumed. }\end{array}$ \\
\hline Technetium $\mathrm{K}_{\mathrm{d}}(\mathrm{mL} / \mathrm{g})$, interbed & $\begin{array}{l}\text { Lognormal: GM } 0.1 \text { and } \\
\text { GSD } 2.78\end{array}$ & $\begin{array}{l}\text { GM is the deterministic value, GSD is } \\
\text { based on the range of } \mathrm{K}_{\mathrm{d}} \text { values } \\
\text { reported in INL }(2011)\end{array}$ \\
\hline $\begin{array}{l}\text { Carbon } \mathrm{K}_{\mathrm{d}}(\mathrm{mL} / \mathrm{g}) \text {, } \\
\text { cement-impacted alluvium }\end{array}$ & Lognormal: GM 2 and GSD 1.83 & $\begin{array}{l}\text { GM is the deterministic value, GSD is } \\
\text { based on the range of } K_{d} \text { values } \\
\text { reported in INL }(2011)\end{array}$ \\
\hline $\begin{array}{l}\text { Carbon } \mathrm{K}_{\mathrm{d}}(\mathrm{mL} / \mathrm{g}) \text {, } \\
\text { cement-impacted sand/gravel base } \\
\text { layer }\end{array}$ & No distribution, $K_{d}=0$ & $\begin{array}{l}\text { Deterministic value is zero; no } \\
\text { distribution assumed. }\end{array}$ \\
\hline Carbon $\mathrm{K}_{\mathrm{d}}(\mathrm{mL} / \mathrm{g})$, interbed & $\begin{array}{l}\text { Lognormal: GM } 0.5 \text { and } \\
\text { GSD } 1.83\end{array}$ & $\begin{array}{l}\text { GM is the deterministic value, GSD is } \\
\text { based on the range of } K_{d} \text { values } \\
\text { reported in INL }(2011)\end{array}$ \\
\hline Infiltration rate $(\mathrm{m} /$ year $)$ & $\begin{array}{l}\text { Triangular: minimum } 0.0025 \text {, } \\
\text { mode } 0.01 \text {, and maximum } 0.04\end{array}$ & $\begin{array}{l}\text { Assumed to be } \pm \text { a factor of } 4 \text { from the } \\
\text { deterministic value }\end{array}$ \\
\hline \multirow[t]{2}{*}{ Darcy velocity in aquifer (m/year) } & $\begin{array}{l}\text { Triangular: minimum } 10, \\
\text { mode } 16 \text {, and maximum } 20\end{array}$ & $\begin{array}{l}\text { Based on variability of Darcy velocity } \\
\text { in the RH-LLW area }\end{array}$ \\
\hline & Inventory (scaling factors) & \\
\hline NRF Activated Metals & $\begin{array}{l}\text { Triangular: minimum } 0.35 \text {, } \\
\text { mode } 1.0 \text {, maximum } 1.5\end{array}$ & $\begin{array}{l}\text { Based on the minimum and maximum } \\
\text { variability estimated by NRF (NRF } \\
\text { 2011). }\end{array}$ \\
\hline NRF Resins (all) & $\begin{array}{l}\text { Triangular: minimum } 0.25 \text {, } \\
\text { mode } 1.0 \text {, maximum } 10\end{array}$ & $\begin{array}{l}\text { Based on the minimum and maximum } \\
\text { variability estimated by NRF (NRF } \\
\text { 2011). }\end{array}$ \\
\hline NRF Surface Contamination & $\begin{array}{l}\text { Triangular: minimum } 0.35 \text {, } \\
\text { mode } 1.0 \text {, maximum } 1.5\end{array}$ & $\begin{array}{l}\text { Minimum and maximum assumed } \\
\text { same as NRF activated metals since } \\
\text { surface contamination on NRF metals } \\
\text { supplied as a fraction of the activated } \\
\text { metal activity. }\end{array}$ \\
\hline ATR Activated Metals & $\begin{array}{l}\text { Triangular: minimum } 0.35 \text {, } \\
\text { mode } 1.0 \text {, maximum } 1.5\end{array}$ & $\begin{array}{l}\text { Minimum and maximum assumed } \\
\text { same as NRF activated metals. }\end{array}$ \\
\hline $\begin{array}{l}\text { ATR Resins (Iodine and } \\
\text { Technetium only) }\end{array}$ & $\begin{array}{l}\text { Triangular: minimum } 0.9 \text {, } \\
\text { mode } 1.0, \text { maximum } 1.1\end{array}$ & $\begin{array}{l}\text { Minimum and maximum based on } \\
\text { one-half the standard deviation of the } \\
\text { three highest activity containers. }\end{array}$ \\
\hline MFC Activated Metals & $\begin{array}{l}\text { Triangular: minimum } 0.75 \text {, } \\
\text { mode } 1.0 \text {, maximum } 1.25\end{array}$ & $\begin{array}{l}\text { Range based on estimated minimum } \\
\text { and maximum values for both legacy } \\
\text { and future generated waste (ECAR- } \\
\text { 904, ECAR-967). }\end{array}$ \\
\hline
\end{tabular}




\begin{tabular}{lll}
\hline \multicolumn{1}{c}{ Parameter } & \multicolumn{1}{c}{ Statistical Distribution } & \multicolumn{1}{c}{ Comments/Reference } \\
\hline $\begin{array}{l}\text { MFC Surface Contamination \& } \\
\text { Debris }\end{array}$ & $\begin{array}{l}\text { Triangular: minimum 0.75, } \\
\text { mode 1.0, maximum 1.25 }\end{array}$ & $\begin{array}{l}\text { Range based on estimated minimum } \\
\text { and maximum values for both legacy } \\
\text { and future generated waste (ECAR- }\end{array}$ \\
$\begin{array}{ll}\text { 904, ECAR-967). } \\
\text { GM = geometric mean }\end{array}$ & & \\
GSD $=$ geometric standard deviation & & \\
\hline
\end{tabular}

\subsubsection{Parametric Uncertainty Analysis Results}

The parameter uncertainty analysis output variable included the radionuclide-specific concentration for comparison to the MCL and the all-pathways EDE. Distributions of model output were developed from 1,000 model realizations. This was deemed to be a sufficient number of realizations to reflect the potential range of results. A confidence interval around percentiles of the output distribution was defined using a distribution-free approach developed in Hahn and Meeker (1991). The approach developed by Hahn and Meeker (1991) uses ordered statistics to define an interval where the true value of a given percentile lies at a specified level of confidence. In this way, confidence for any given percentile within the distribution could be defined. Of particular interest are the tails (i.e., top and bottom) of the distribution, because values at the tails of the distribution change more with the number of model realizations; central values are more stable. The ordered statistics for the 5 th and 95 th percentiles for 1,000 model realizations are 50 and 950 , respectively. That is, if the output values for 1,000 realizations are sorted in ascending order, the 5 th percentile represents the 50th highest value and the 95 th percentile represents the 950th highest value. The $95 \%$ confidence interval around the 5 th percentile in terms of the ordered statistics is 37 and 64 . The $95 \%$ confidence interval around the 95 th percentile in terms of the ordered statistics is 936 and 963 . This was interpreted to mean a $95 \%$ confidence that $90 \%$ of the model output lies between the ordered statistics 37 and 963. 25 .

The sample distributions for all parameters considered to be uncertain are given in Figures 23 through 

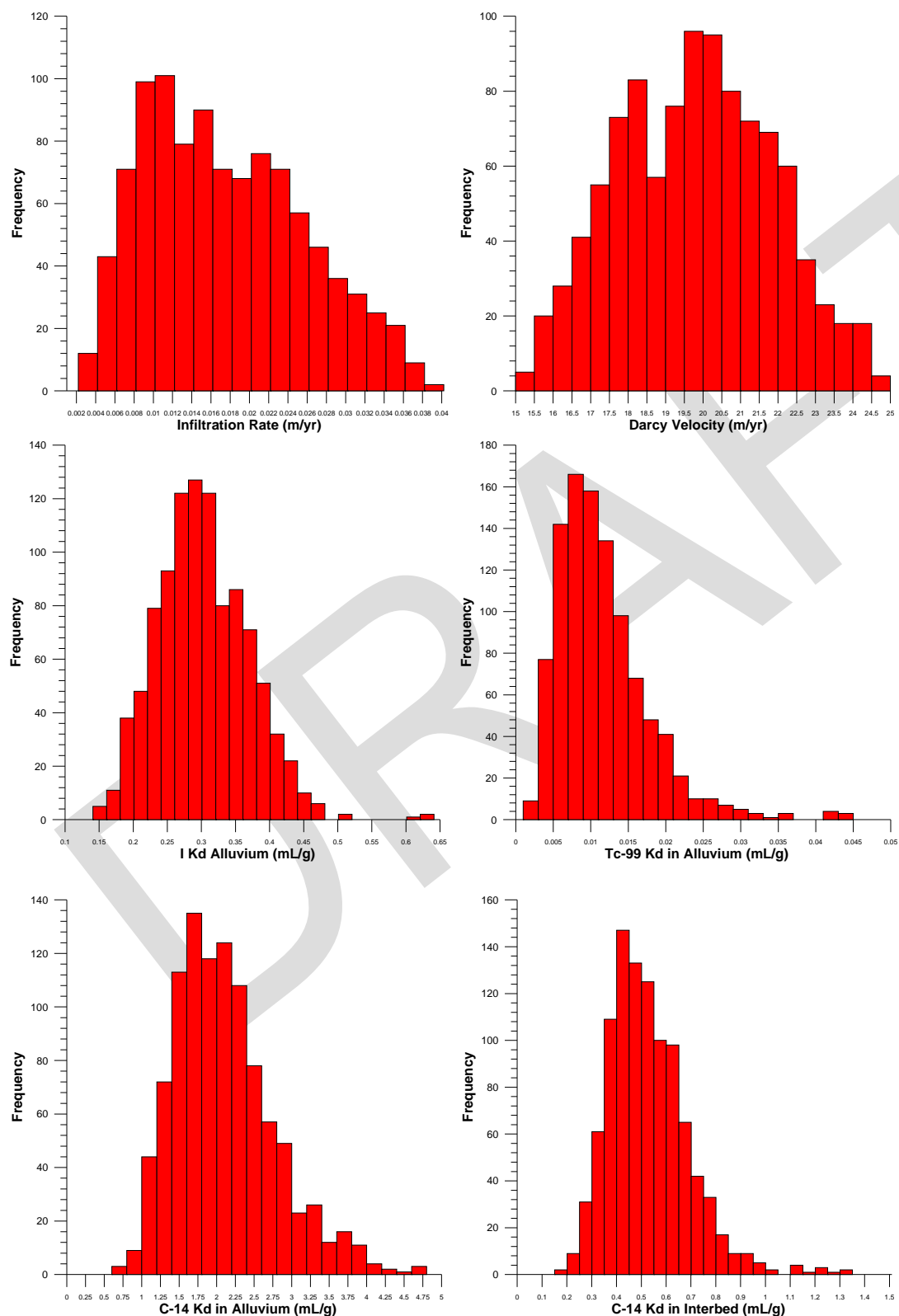

Figure 23. Frequency distributions of sampled parameters 

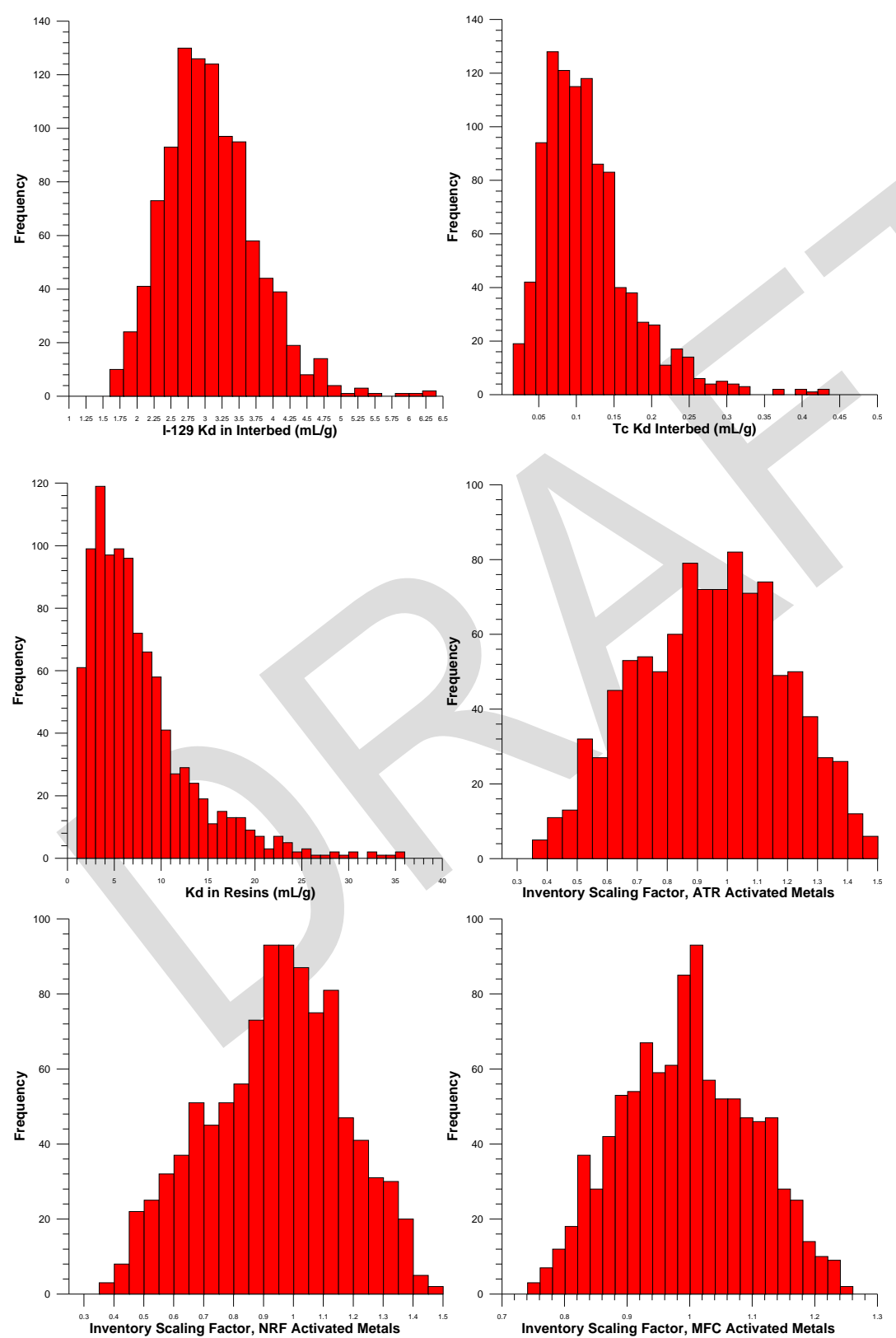

Figure 24. Frequency distributions of sampled parameters 

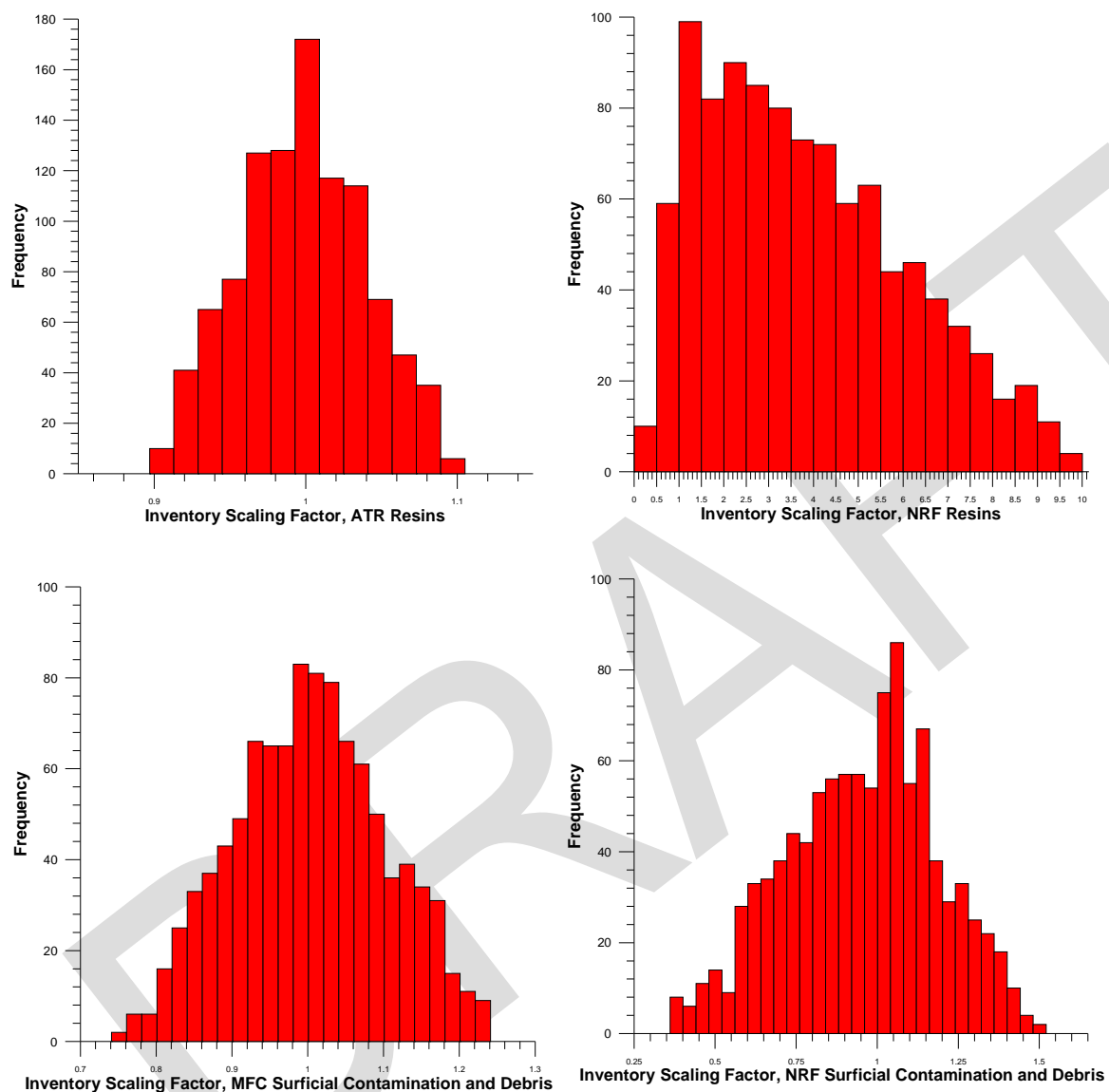

Figure 25. Frequency distributions of sampled parameters

A summary of the sampled parameters (Table 13) shows that mean and median values of the assigned distributions were well represented by the sampled distributions for lognormally distributed parameters. For unsymmetrical triangular distributions, the mean and median values tended to be slightly higher than the mode value. However, for symmetric triangular distributions, the mode was well represented by the mean value of the sampled distribution.

Table 13. Statistics of the sampled parameter distributions for 1,000 model realizations.

\begin{tabular}{lcccc}
\hline \multicolumn{1}{c}{ Parameter } & Minimum & Maximum & Mean & Median \\
\hline Infiltration rate (m/year) & $2.88 \mathrm{E}-03$ & $3.94 \mathrm{E}-02$ & $1.73 \mathrm{E}-02$ & $1.61 \mathrm{E}-02$ \\
Darcy velocity in aquifer (m/year) & $1.01 \mathrm{E}+01$ & $1.99 \mathrm{E}+01$ & $1.53 \mathrm{E}+01$ & $1.54 \mathrm{E}+01$ \\
Resin $\mathrm{K}_{\mathrm{d}}(\mathrm{mL} / \mathrm{g})$ & $1.14 \mathrm{E}+00$ & $1.30 \mathrm{E}+01$ & $6.19 \mathrm{E}+00$ & $5.63 \mathrm{E}+00$ \\
Carbon $\mathrm{K}_{\mathrm{d}}(\mathrm{mL} / \mathrm{g})$, alluvium & $6.58 \mathrm{E}-01$ & $5.37 \mathrm{E}+00$ & $2.09 \mathrm{E}+00$ & $1.99 \mathrm{E}+00$ \\
Iodine $\mathrm{K}_{\mathrm{d}}(\mathrm{mL} / \mathrm{g})$, alluvium & $1.59 \mathrm{E}-01$ & $5.60 \mathrm{E}-01$ & $3.10 \mathrm{E}-01$ & $3.08 \mathrm{E}-01$
\end{tabular}


Table 4-11. (continued).

\begin{tabular}{lcccc}
\hline \multicolumn{1}{c}{ Parameter } & Minimum & Maximum & Mean & Median \\
\hline Technetium $\mathrm{K}_{\mathrm{d}}(\mathrm{mL} / \mathrm{g})$, alluvium & $2.29 \mathrm{E}-03$ & $4.60 \mathrm{E}-02$ & $1.13 \mathrm{E}-02$ & $9.97 \mathrm{E}-03$ \\
Carbon $\mathrm{Kd}(\mathrm{mL} / \mathrm{g})$, interbed & $1.98 \mathrm{E}-01$ & $1.22 \mathrm{E}+00$ & $5.30 \mathrm{E}-01$ & $5.06 \mathrm{E}-01$ \\
Iodine $\mathrm{K}_{\mathrm{d}}(\mathrm{mL} / \mathrm{g})$, interbed & $1.38 \mathrm{E}+00$ & $6.21 \mathrm{E}+00$ & $3.07 \mathrm{E}+00$ & $2.98 \mathrm{E}+00$ \\
Technetium $\mathrm{K}_{\mathrm{d}}(\mathrm{mL} / \mathrm{g})$, interbed & $2.41 \mathrm{E}-02$ & $4.51 \mathrm{E}-01$ & $1.14 \mathrm{E}-01$ & $9.99 \mathrm{E}-02$ \\
Inventory scaling factor, C-14 & $5.07 \mathrm{E}-01$ & $1.48 \mathrm{E}+00$ & $9.94 \mathrm{E}-01$ & $9.94 \mathrm{E}-01$ \\
Inventory scaling factor, I-129 & $5.08 \mathrm{E}-01$ & $1.49 \mathrm{E}+00$ & $1.00 \mathrm{E}+00$ & $1.01 \mathrm{E}+00$ \\
Inventory scaling factor, Tc-99 & $5.39 \mathrm{E}-01$ & $1.48 \mathrm{E}+00$ & $9.98 \mathrm{E}-01$ & $9.96 \mathrm{E}-01$ \\
Inventory scaling factor, U-238 & $5.17 \mathrm{E}-01$ & $1.50 \mathrm{E}+00$ & $1.00 \mathrm{E}+00$ & $1.01 \mathrm{E}+00$
\end{tabular}

Results for Candidate Site 5 are given in Figures 26 through 29. The distribution of C-14 concentration as a function of time is illustrated in Figure 26 for comparison to its MCL of $2000 \mathrm{pCi} / \mathrm{L}$. The uncertainty bounds (the shaded area on Figure 26) span from the 2.5th to the 97.5th percentile and represent $95 \%$ of the output distribution. The span of the distribution (i.e., from 2.5 to $97.5 \%$ ) varies with time and is in response to variability in the distribution coefficients, infiltration, and Carbon-14 inventory. The deterministic concentrations and $97.5 \%$ upper confidence limit concentrations are both much lower than the MCL.

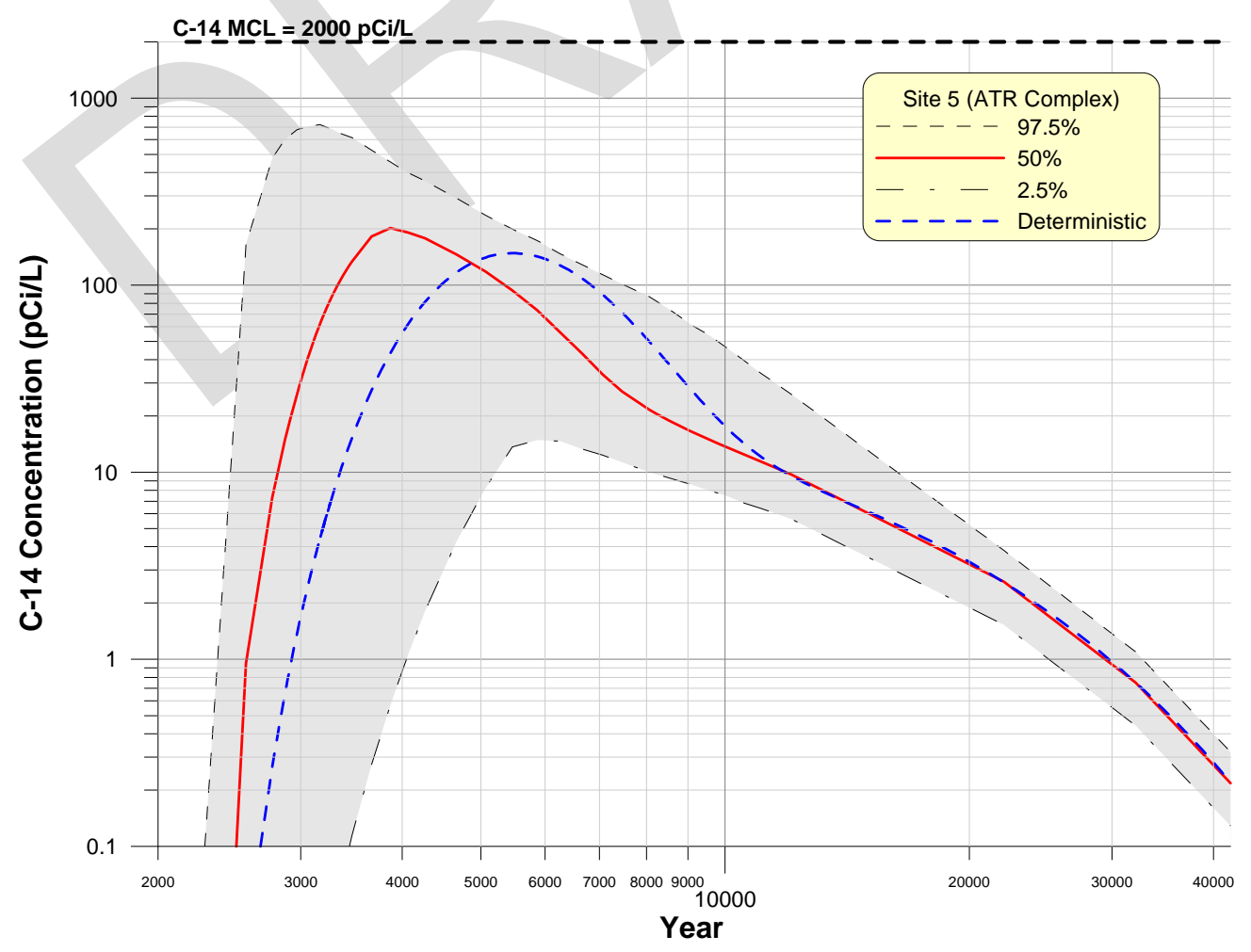


Figure 26. Carbon-14 concentrations with uncertainty bounds as a function of time for Site 5 (ATR Complex). The shaded area represents the region encompassed by the 2.5 and 97.5 percentile values. Carbon-14 concentrations, both in the deterministic and Monte Carlo case, do not exceed the $2000 \mathrm{pCi} / \mathrm{L}$ MCL.

The distribution of Iodine-129 concentration as a function of time is illustrated in Figure 27 for comparison to its MCL of $1 \mathrm{pCi} / \mathrm{L}$. The uncertainty bounds (the shaded area on Figure 27) span from the 2.5 th to the 97.5 th percentile and represent $95 \%$ of the output distribution. The span of the distribution (i.e., from 2.5 to $97.5 \%$ ) varies with time and is in response to variability in the distribution coefficients, infiltration, and Iodine-129 inventory. The deterministic concentrations and $97.5 \%$ upper confidence limit concentrations are both much lower than the MCL.

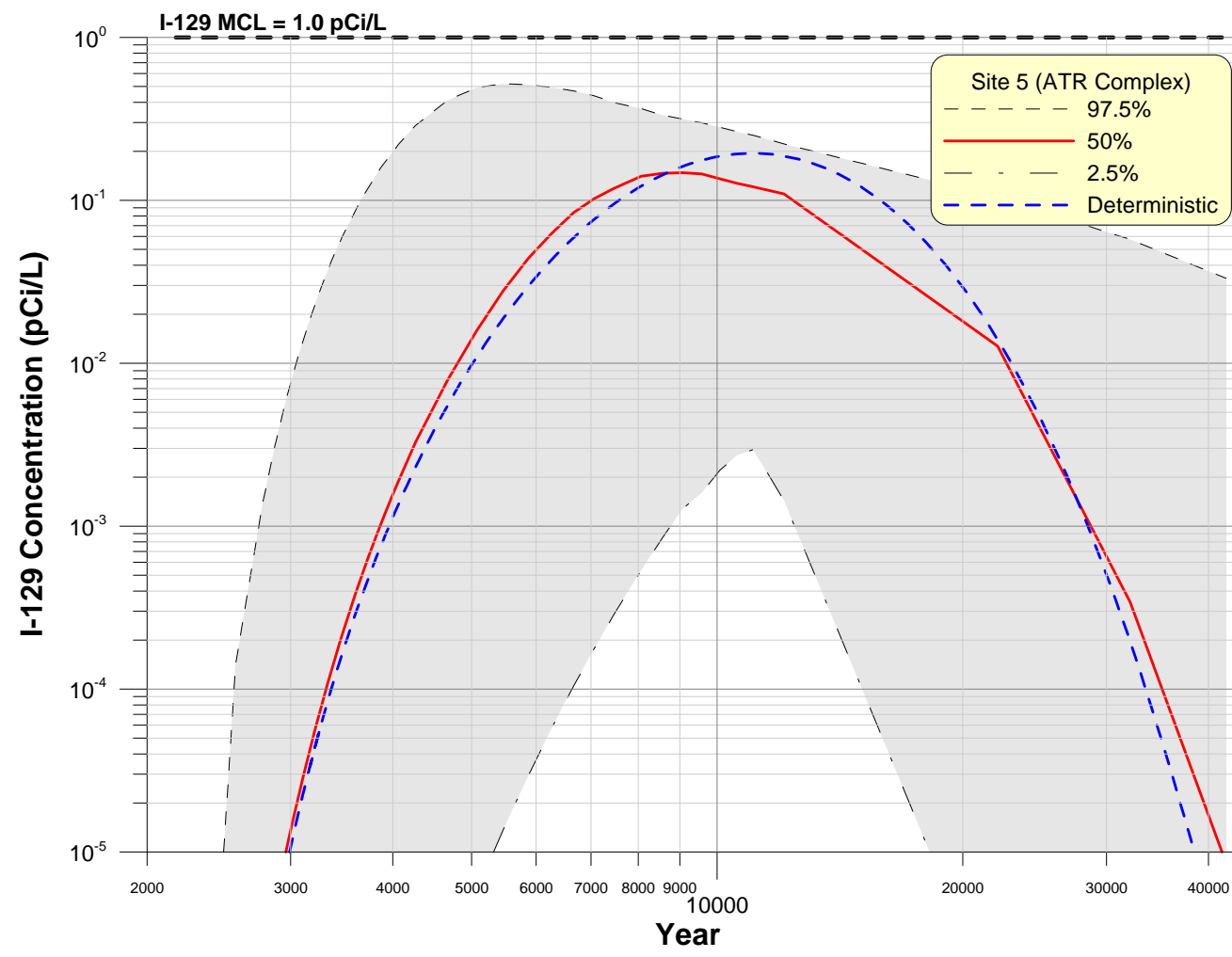

Figure 27. Iodine-129 concentrations with uncertainty as a function of time for Site 5 (ATR Complex). The shaded area represents the region encompassed by the 2.5 and 97.5 percentile values. Iodine-129 concentrations, both in the deterministic and Monte Carlo case, do not exceed the $1 \mathrm{pCi} / \mathrm{L} \mathrm{MCL}$.

The uncertainty for Tc-99 concentrations are given in Figure 28. The 97.5\% confidence limit computed from the Monte Carlo simulation provides the more conservative estimate of peak Tc-99 concentration. It suggests that the peak will occur earlier than indicated by the deterministic base case. The earlier higher bounding concentrations predicted by the Monte Carlo simulations occurs because higher concentrations are associated with lower $\mathrm{Kd}$ values and higher infiltration rates, resulting in faster 
vadose zone travel times. The shift in the $97.5 \%$ confidence limits relative to the Tc-99 deterministic case less pronounced because the product of bulk density and mean $\mathrm{Kd}$ for all materials is small relative to 1 in the calculation: $\mathrm{R}=(1+\mathrm{kd} *$ density $) /$ moisture content (i.e., a factor of 2 change in $\mathrm{Kd}$ does not double the retardation factor).

Additionally, the resin $\mathrm{Kd}$ in the deterministic case is zero, resulting in a leaching rate equal to that of miscellaneous trash and surficial contamination, which also have a $\mathrm{Kd}$ of zero. Consequently, the peaks from these two waste streams (resins and surface contamination/debris) arrive at the aquifer at the same time in the deterministic case. The Monte Carlo simulation used a distribution of resin Kd values having a geometric mean of 6 and an geometric standard deviation of 2. Consequently, leaching from the resin waste form extends for a much longer period of time and results in higher concentrations compared to the deterministic case beyond about year 3000. Near year 3000, most of the Tc-99 in the deterministic case arrives in a single pulse, resulting in a slightly higher concentration than the 97.5 percentile at the year. The deterministic dose drops of rapidly while in the Monte Carlo case, the dose gradually decreases over time. Beyond year 20,000 the deterministic case and the Monte Carlo $50^{\text {th }}$ percentile begin to converge.

Concentrations in this time frame are from activated metal releases.

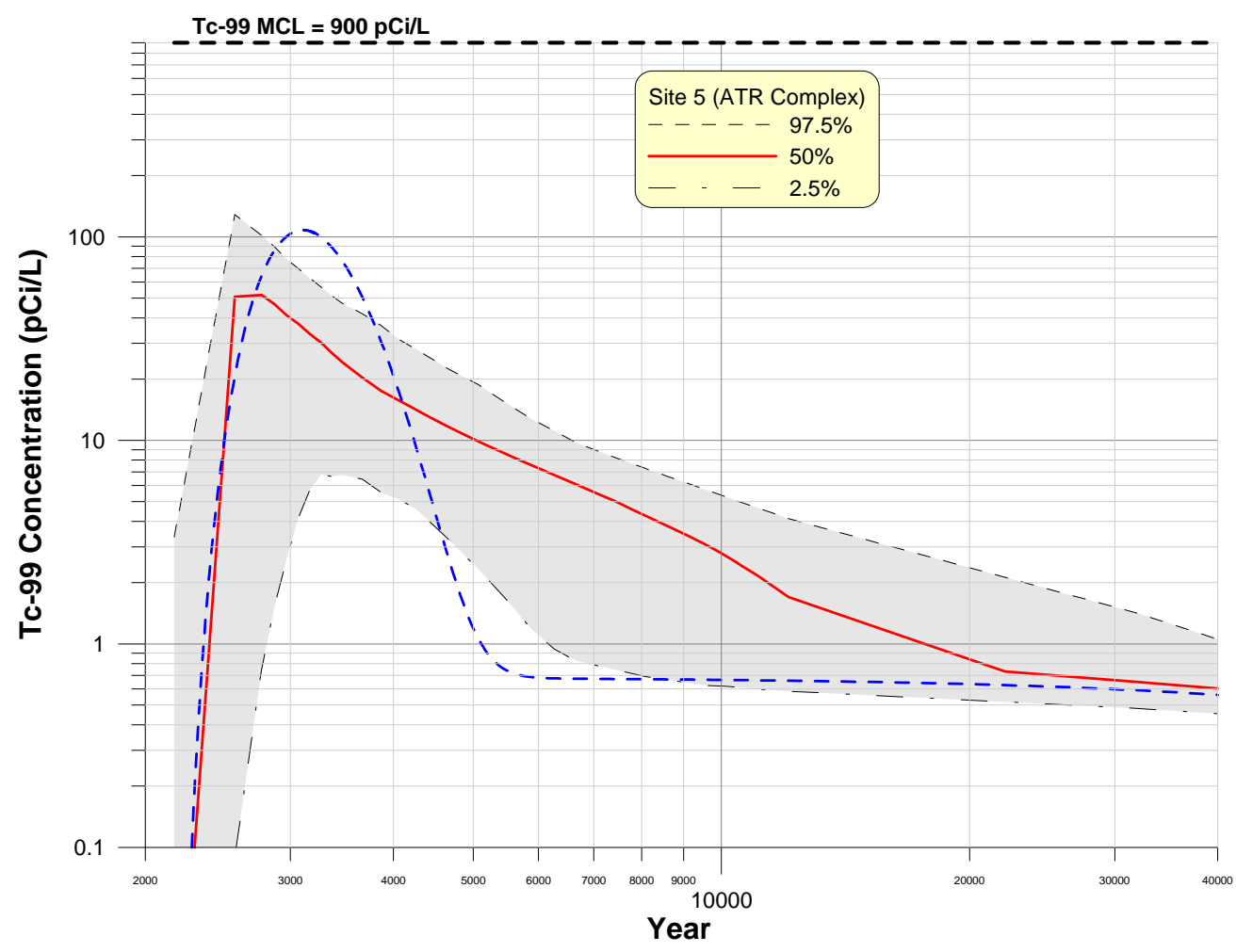

Figure 28. Technetium -99 concentrations with uncertainty as a function of time for Site 5 (ATR

Complex). The shaded area represents the region encompassed by the 2.5 and 97.5 percentile values.

Technetium-99 concentrations, both in the deterministic and Monte Carlo case, do not exceed the 900 pCi/L MCL. 
The deterministic all-pathways dose falls for Candidate Site 5 within the $95 \%$ confidence intervals for times less than year 10,000 is shown in Figure 29. Deterministic doses after year 10,000 are dominated by I-129 from resins. The deterministic case used a Kd of zero for the resins, and consequently, the release rate is higher compared to the Monte Carlo case, which used a Kd of 0 for the resins. However, the I- 129 released from the resins is buffered in the vadose zone because the $\mathrm{Kd}$ value is $3 \mathrm{~mL} / \mathrm{g}$. By 10,000 years, most of the I-129 activity is in the vadose zone for the deterministic case, but in the Monte Carlo case, about $20 \%$ of the activity remains in the waste zone. Therefore, the I-129 concentrations would be higher in the deterministic case after 10,000 years compared to the Monte Carlo case.

All-pathway doses before year 10,000 are dominated by Tc-99 in resins (and to a lesser extent miscellaneous trash) and C-14 in miscellaneous trash. In the deterministic case, the resin Kds are zero and there are distinct peaks for C-14 and Tc-99, with Tc-99 arriving earlier than C-14. In the Monte Carlo simulations, the resin Kd delays the release of Tc-99 and results in a merging of the C-14 and Tc-99 peaks. The peak deterministic all-pathways dose occurs at a later time than the peak all-pathways dose from the Monte Carlo simulation for the 97.5 percentile and about the same time for the 2.5 percentile. The reason for this difference is because higher doses are associated with higher infiltration rates and lower Kd values, resulting in the highest doses occurring at an earlier time compared to the deterministic case. Likewise, lower doses are associated with lower infiltration rates and higher Kd values, resulting in doses that occur at or later than the deterministic dose.

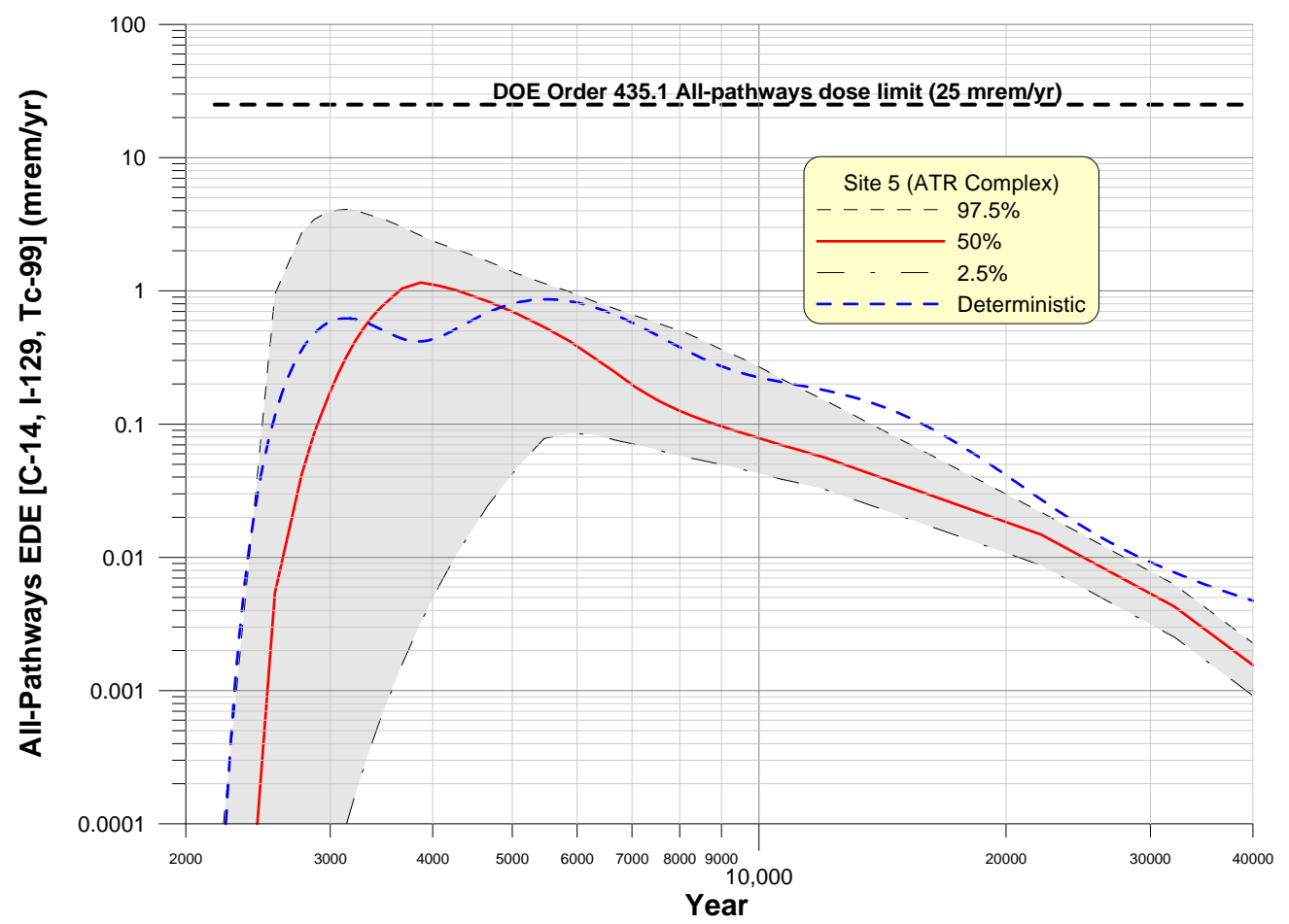

Figure 29. All Pathway Dose with uncertainty as a function of time for Site 5 (ATR Complex). The shaded area represents the region encompassed by the 2.5 and 97.5 percentile values. All-pathway doses, both in the deterministic and Monte Carlo case, do not exceed the $25 \mathrm{mrem} / \mathrm{yr}$ dose criteria stated in DOE Order 435.1. 
The behavior in uncertainty is similar at Candidate Sites 5 and 34 because the same parameter distributions were used. Results for Candidate Site 34 (INTEC) are given in Figures 30 through 33 to allow comparison to the MCL for Carbon-14, Iodine-129, and Tc-99. For each radionuclide, the deterministic concentrations and $97.5 \%$ upper confidence limit concentrations are both much lower than the MCL. The deterministic all-pathways dose for Candidate Site 34 falls within the $95 \%$ confidence intervals for times less than year 10,000 as shown in Figure 33.

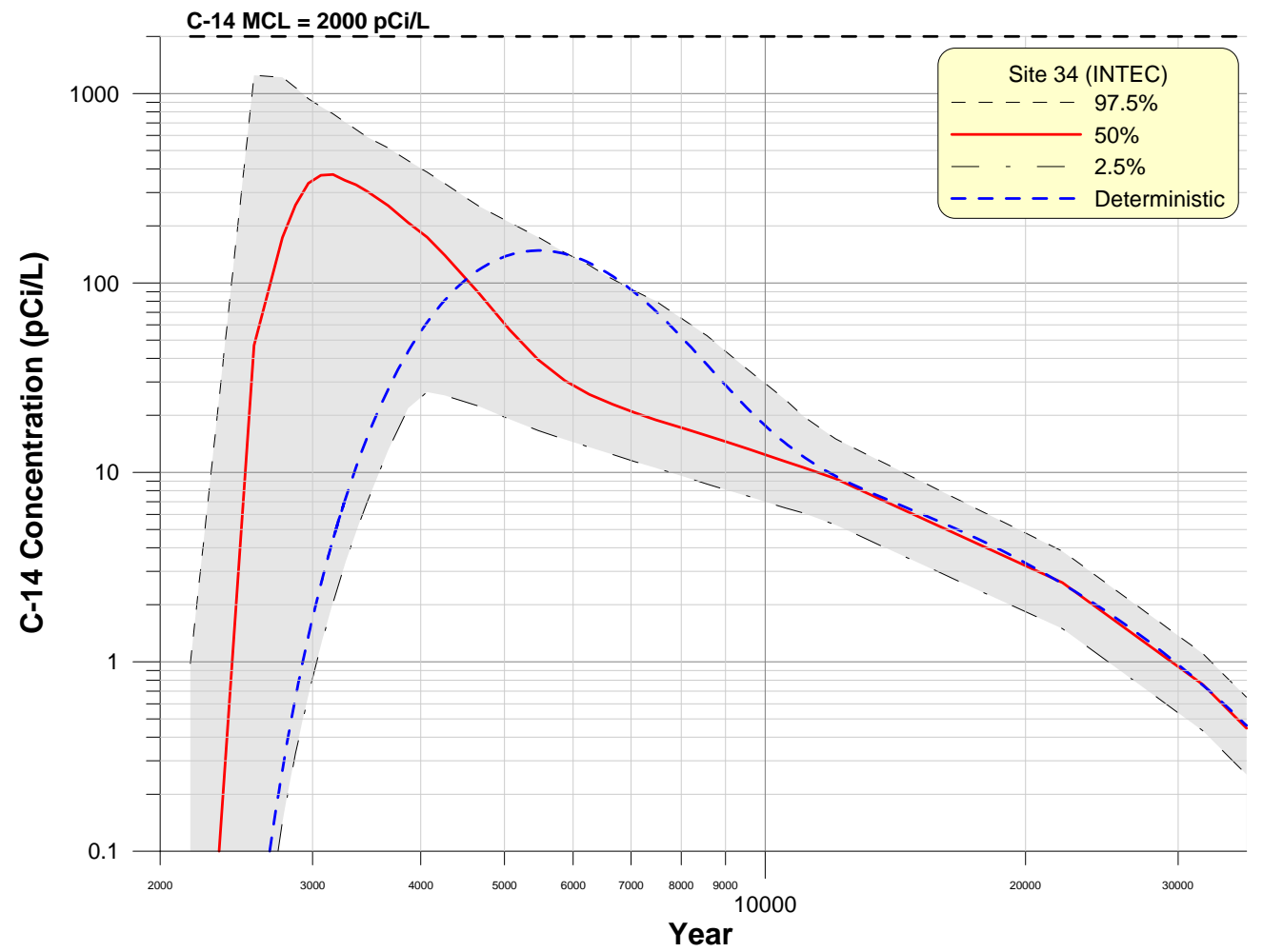

Figure 30. Carbon-14 concentrations with uncertainty as a function of time for Site 34 (INTEC). The shaded area represents the region encompassed by the 2.5 and 97.5 percentile values. Carbon-14 concentrations, both in the deterministic and Monte Carlo case, do not exceed the $2000 \mathrm{pCi} / \mathrm{L}$ MCL. 


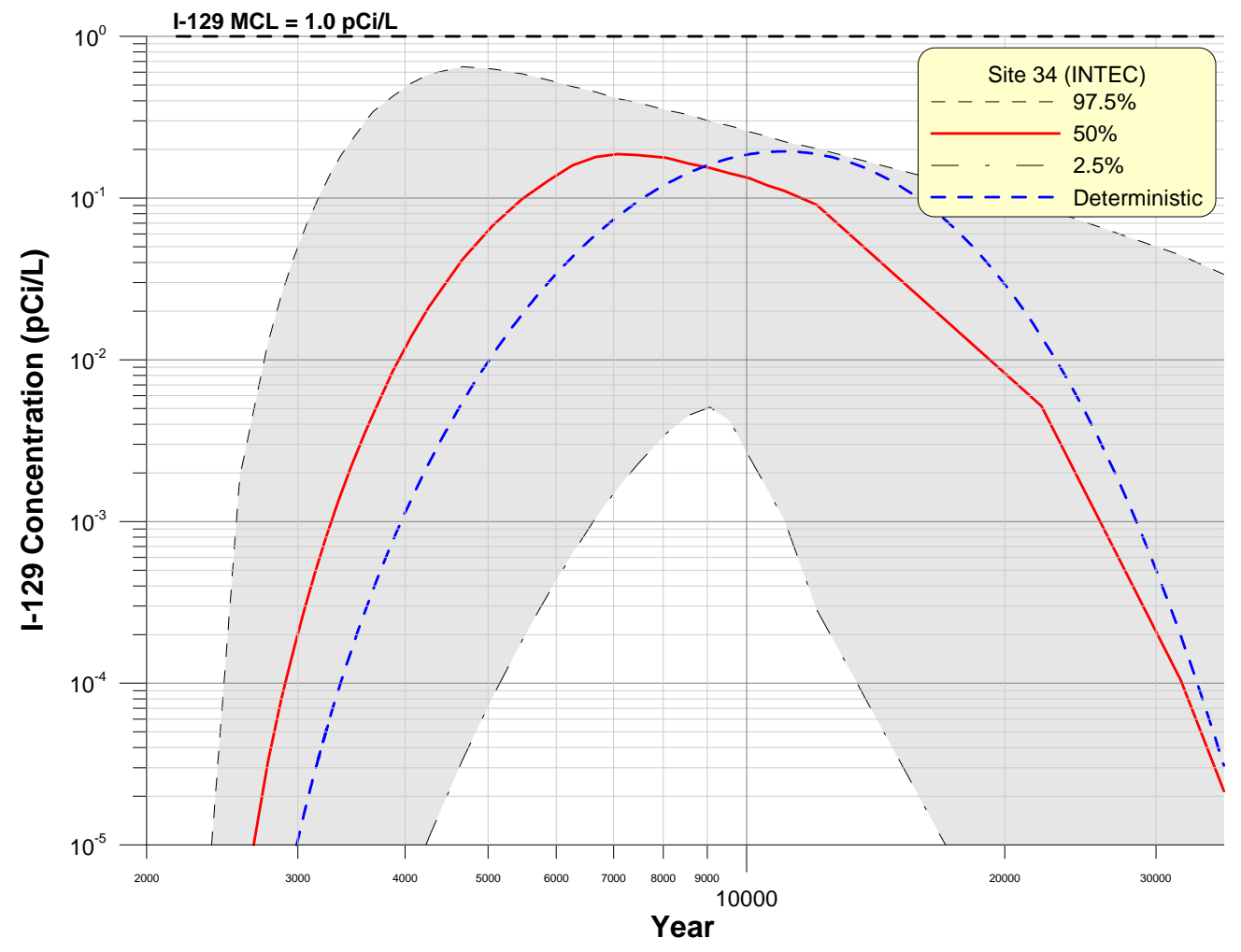

Figure 31. Iodine-129 concentrations with uncertainty as a function of time for Site 34 (INTEC). The shaded area represents the region encompassed by the 2.5 and 97.5 percentile values. Iodine- 129 concentrations, both in the deterministic and Monte Carlo case, do not exceed the $1 \mathrm{pCi} / \mathrm{L} \mathrm{MCL}$. 


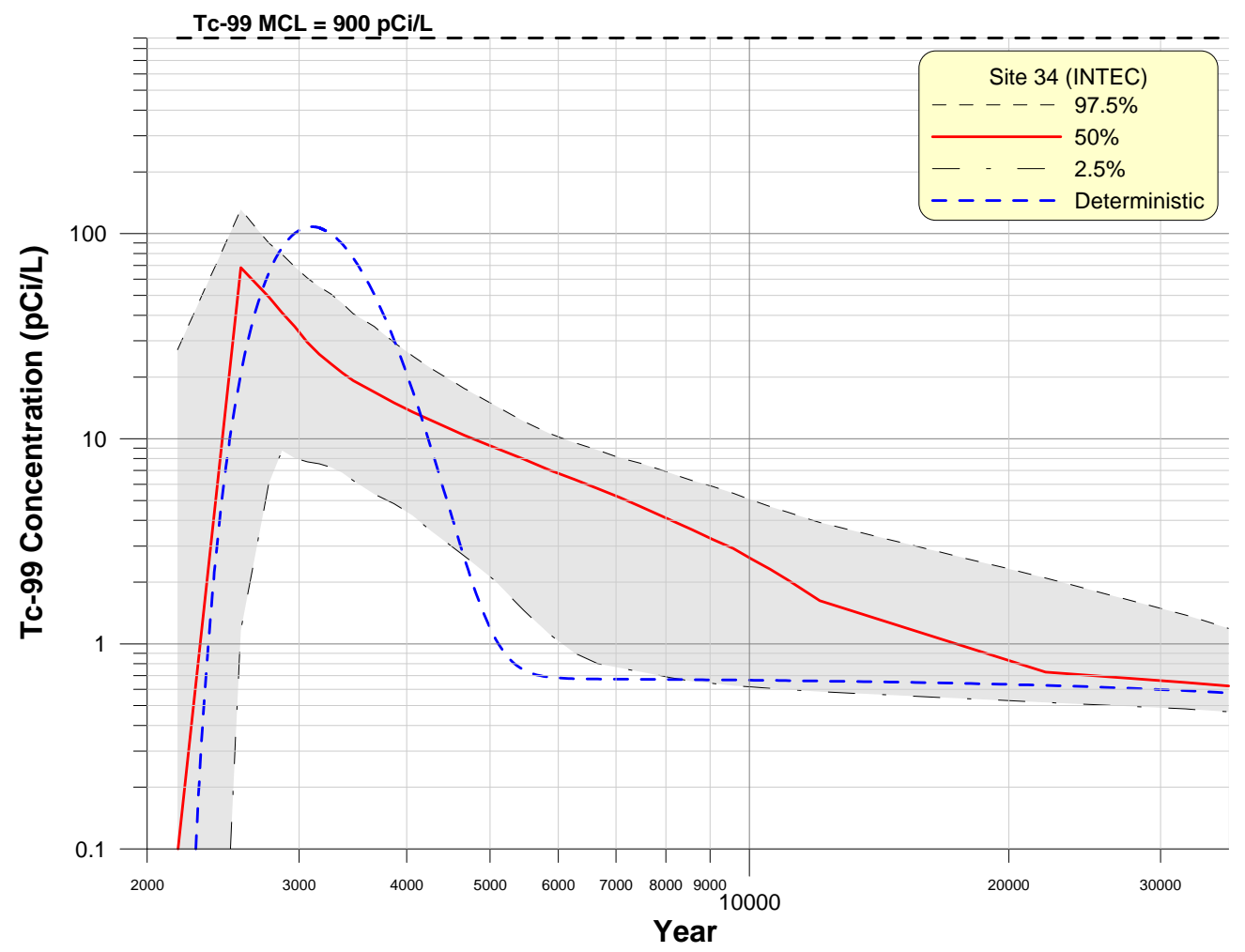

Figure 32. Technetium -99 concentrations with uncertainty as a function of time for Site 34 (INTEC).

The shaded area represents the region encompassed by the 2.5 and 97.5 percentile values. Technetium- 99 concentrations, both in the deterministic and Monte Carlo case, do not exceed the $900 \mathrm{pCi} / \mathrm{L}$ MCL. 


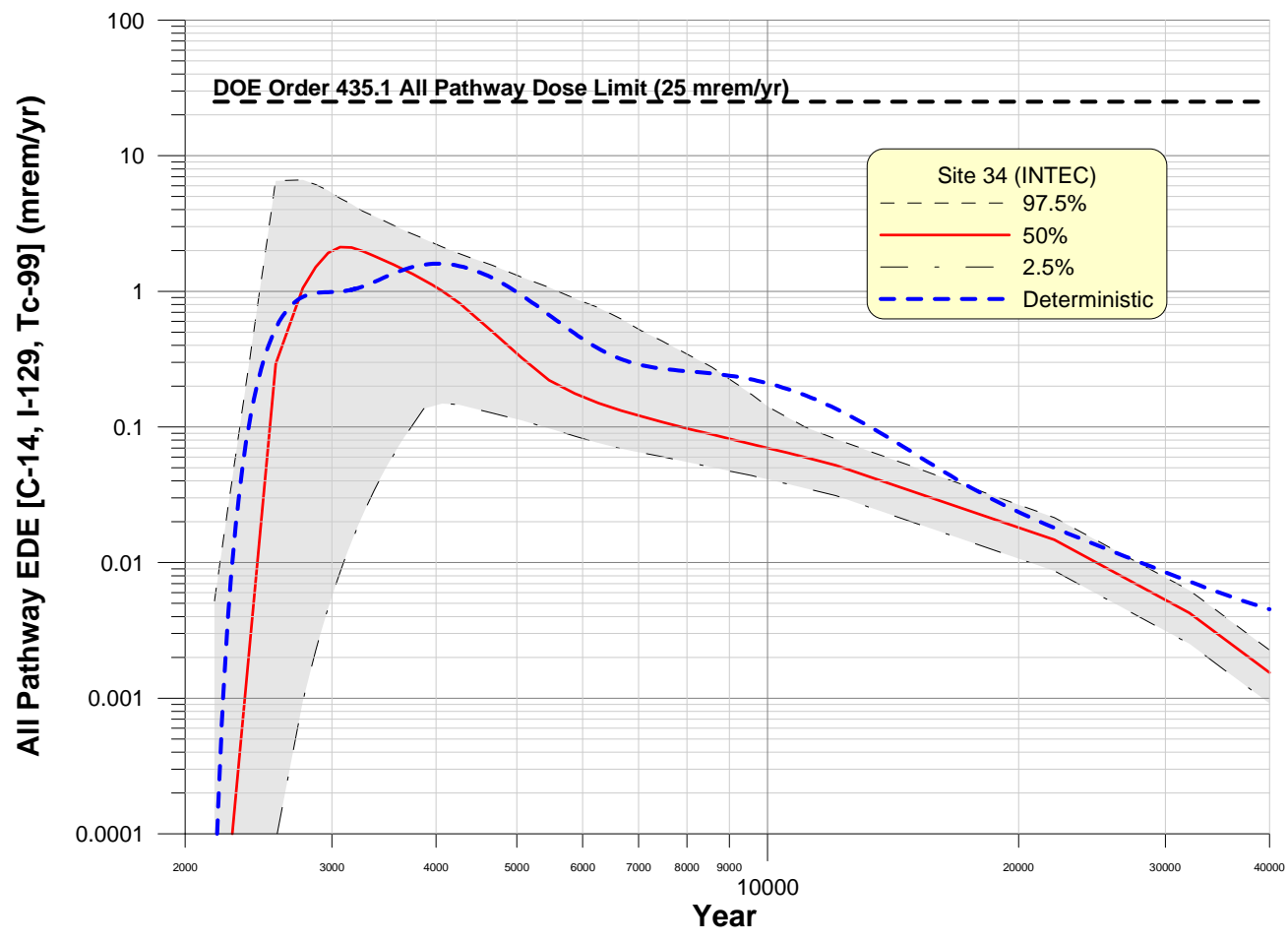

Figure 33. All Pathway Dose with uncertainty as a function of time for Site 43 (INTEC). The shaded area represents the region encompassed by the 2.5 and 97.5 percentile values. All-pathway doses, both in the deterministic and Monte Carlo case, do not exceed the $25 \mathrm{mrem} / \mathrm{yr}$ dose criteria stated in DOE Order 435.1 .

\section{COMPOSITE IMPACTS}

Assessing the cumulative or composite impacts to groundwater requires consideration of other sources of contaminants that currently exist in the aquifer or will enter the aquifer in the future. Locations of the sources include upgradient contaminants that could migrate through the aquifer volume potentially impacted by the RH-LLW disposal facility, nearby sources that could overlap the impacted region, and those sources downgradient that might be impacted by the RH-LLW disposal facility. Because Site 34 and Site 5 are separated by approximately 1.5 miles, the near-field composite analysis is site dependent. However, over longer times and transport distances, potentially overlapping downgradient sources for both proposed sites are similar. The near-field analysis is provided for both sites separately, followed by a single far-field analysis.

Candidate Site 5 is essentially located downgradient of the ATR Complex and NRF. There are no predicted or existing contaminants of concern in the aquifer upgradient of NRF with the potential to impact groundwater concentrations at Site 5. There have been historical releases within the ATR Complex identified and partially remediated through CERCLA activities (Dames and Moore 1992, DOE-ID 1997a). Contaminants of concern at the ATR Complex included chromium, tritium, Sr-90, and cadmium. Peak concentrations for all of these were predicted to be below their respective MCLs by the year 2029. Historical releases addressed under CERCLA within the Naval Reactor Facility are 
summarized in Westinghouse (1997). In the cumulative risk assessment for NRF, radionuclides evaluated as potential groundwater contaminants included C-14, Np-237, Pu-239, Pu-234, U-234, and U-235.

Since the time CERCLA evaluations of NRF and the ATR Complex were performed, significant advances in understanding of groundwater flow and transport at INL have occurred and changes to dose coefficients have been implemented (EPA 1999, EPA 2002). To account for these advances, and to ensure doses were appropriately accounted for at Site 5, doses were reevaluated and are presented in Appendix A. This analysis concluded that the CERCLA results were extremely conservative for NRF and for ATR with the exception of C-14 at NRF. The original NRF analysis predicted the C-14 peak dose to be $1.3 \mathrm{mrem} /$ year at 271 years after disposal while the reanalysis predicted it to be $2.56 \mathrm{mrem} /$ year at 45 years after disposal. The primary reason for the increase in dose and an earlier arrival is a lower sorption coefficient used in the reanalysis. Nevertheless, the peak time in either case is more than 3,000 years before the RH-LLW peak dose $(0.849 \mathrm{mrem} /$ year $)$ is predicted to occur. Therefore, the peak C-14 dose at NRF is not expected to overlap in time to any great extent with doses from the RH-LLW facility.

After C-14, the radionuclide with the next highest dose from NRF is U-234. The peak dose is predicted to be $0.0195 \mathrm{mrem} /$ year and occur 40,750 years after disposal. The peak dose at the ATR Complex from historical releases is $0.0272 \mathrm{mrem} /$ year (also from U-234) and predicted to occur 41,750 years after disposal. These are very low relative to the peak RH-LLW dose and occur much later in time than the peak RH-LLW peak dose. The peak dose from the RH-LLW facility, at approximately 40,000 years after disposal, is predicted to be about $0.15 \mathrm{mrem} /$ year (from U-238). If the peak U-234 doses from NRF and the ATR Complex were added to this, the combined dose would be $0.21 \mathrm{mrem} /$ year and still be much less than the peak RH-LLW dose. Based on this information, which is summarized in Table 14, it is very unlikely that either the ATR Complex or NRF will increase the dose over and above what is predicted for the RH-LLW facility. This does not even consider that there will be substantial dilution between the NRF facility and Candidate Site 5, and some dilution between the ATR Complex and Candidate Site 5.

Table 14. Summary of primary potential dose contributions to predicted doses for Site 5.

\begin{tabular}{|c|c|c|c|}
\hline Source & Nuclide(s) & $\begin{array}{c}\text { Peak Dose } \\
\text { (mrem/year EDE) }\end{array}$ & $\begin{array}{c}\text { Time of Peak Dose } \\
\text { (CY) }\end{array}$ \\
\hline NRF & C-14 & 2.56 & $2025^{\mathrm{a}}$ \\
\hline NRF & U-234 & 0.0195 & $42730^{\mathrm{b}}$ \\
\hline ATR & U-234 & 0.0272 & $43730^{\mathrm{b}}$ \\
\hline Site 5 RH-LLW & Mostly C-14 & 0.876 & 5518 \\
\hline
\end{tabular}

Predicted peak dose after RH-LLW operations cease in 2067 and time of peak

About $0.876 \quad 5518$

\footnotetext{
a. $\quad$ Peak dose from C-14 predicted to occur at NRF will be reduced by dilution prior to reaching the proposed facility

location and will occur during the 50 -year operating period of the proposed disposal facility.

b. Based on disposal time of 1980 and the peak time from the NRF and ATR Complex reanalysis (Appendix A)
}

Candidate Site 34 is located southwest of INTEC (Figure 1). There are no predicted or existing contaminants with the potential of impacting the aquifer upgradient of INTEC. Contaminant sources with the potential to impact Candidate Site 34 include residual radionuclides from historical releases at INTEC evaluated under CERCLA, radionuclides disposed of in ICDF located southwest of INTEC, and the residual inventory in the Tank Farm Facility at INTEC. 
The CERCLA investigations for INTEC perched water, aquifer, and contaminated soils conducted under OU 3-14 (DOE-ID 2007b) identified I-129, Tc-99, H-3, Sr-90, Np-237, and nitrate as contaminants of concern for groundwater. A record of decision was signed in 2007 for OU 3-14 (DOE-ID 2007b), and remedies were selected to ensure contaminants of concern would be below their respective MCLs by the year 2095 for all constituents. Groundwater monitoring results show that H-3 and I-129 concentrations within the aquifer have dropped below drinking water MCLs at all aquifer monitoring wells within and downgradient of INTEC; Sr-90 is the only radionuclide associated with historical operations at INTEC that currently exceeds MCLs downgradient of the facility (DOE-ID 2010).

The INTEC CERCLA investigations (DOE-ID 1997b, DOE 2007b) were not required to predict allpathways doses and therefore, did not evaluate the contribution to dose by progeny. To ensure all potential doses from these sources are accounted for, doses from INTEC for radionuclides with the potential to affect long-term groundwater doses (Np-237, U-234, Pu-239, and $\mathrm{Pu}-240$ ) were evaluated and the results are shown in Table 15. The relevant sources are exclusively in contaminated soils. The predicted dose shown in Table 15 from the INTEC CERCLA sites was obtained by dividing the INTEC source inventory by the NRF inventory and multiplying by the predicted dose at NRF (computed in Appendix A). The largest predicted dose from the contaminated soils at INTEC is $0.224 \mathrm{mrem} /$ year for U234. Assuming the same peak time as the NRF reanalysis, the peak dose occurs 40,750 years after release or about CY 42750. The doses from Np-237 and Pu-239/240 are much lower at 6.23E-03 and 1.79E-04 $\mathrm{mrem} / \mathrm{year}$ respectively. Because the peak times for plutonium and neptunium will be farther out in time because of their reduced mobility (larger $K_{d}$ values) and the peak doses are smaller than U-234, only the dose from U-234 is likely to impact the RH-LLW facility and is shown in Table 14.

Table 15. Potential doses from Operable Unit 3-14 soils scaled from reanalysis of Naval Reactors Facility releases.

\begin{tabular}{lcccrrr}
\hline Nuclide & $\begin{array}{c}\text { NRF } \\
\text { Inventory } \\
(\mathrm{Ci})\end{array}$ & $\begin{array}{c}\text { NRF Time of } \\
\text { Peak Dose } \\
\text { (years after } \\
\text { disposal) }\end{array}$ & $\begin{array}{c}\text { NRF Peak } \\
\text { Dose } \\
\text { (mrem/year } \\
\text { EDE) }\end{array}$ & $\begin{array}{c}\text { NRF Scale } \\
\text { Factor } \\
\text { (mrem/year/Ci) }\end{array}$ & $\begin{array}{c}\text { OU 3-14 } \\
\text { Inventory } \\
\text { (Ci) }\end{array}$ & $\begin{array}{c}\text { OU 3-14 Scaled } \\
\text { Dose } \\
\text { (mrem/year } \\
\text { EDE) }\end{array}$ \\
\hline Np-237 & 0.0667 & 70,750 & $2.59 \mathrm{E}-03$ & 0.0388 & 0.160 & $6.21 \mathrm{E}-03$ \\
$\mathrm{Pu}-239$ & 0.0631 & 59,750 & $1.23 \mathrm{E}-06$ & $1.95 \mathrm{E}-05$ & $9.20^{\mathrm{a}}$ & $1.79 \mathrm{E}-04$ \\
$\mathrm{U}-234$ & 0.0277 & 40,750 & 0.0195 & 0.704 & 0.318 & 0.224 \\
\hline
\end{tabular}

a. Includes Pu-239 and Pu-240 inventories from OU 3-14.

ICDF is located near the southwest corner of the INTEC facility and directly east of Candidate Site 34 (Figure 34). CERCLA waste from INTEC and other INL facilities are consolidated in ICDF. Radionuclide migration and resultant concentrations and doses were predicted by a performance assessment for ICDF (DOE-ID 2010). The peak all-pathways dose $100 \mathrm{~m}$ downgradient from ICDF is predicted to be $0.584 \mathrm{mrem} /$ year and occurs in year 8363. This is shown in Table 16 .

Residual radionuclides from closure of the Tank Farm Facility at INTEC have the potential to impact groundwater. The groundwater all-pathways dose for the Tank Farm Facility closure was reported in (DOE-ID 2003d). Within the 1,000-year compliance period, the peak groundwater all-pathways EDE was predicted to occur about 900 years post-closure and be $1.4 \mathrm{mrem} / \mathrm{year}$, mostly from I-129. After 1,000 years, the peak groundwater all-pathways EDE is $0.87 \mathrm{mrem} /$ year at 14,600 years post-closure, mostly from Tc-99. 


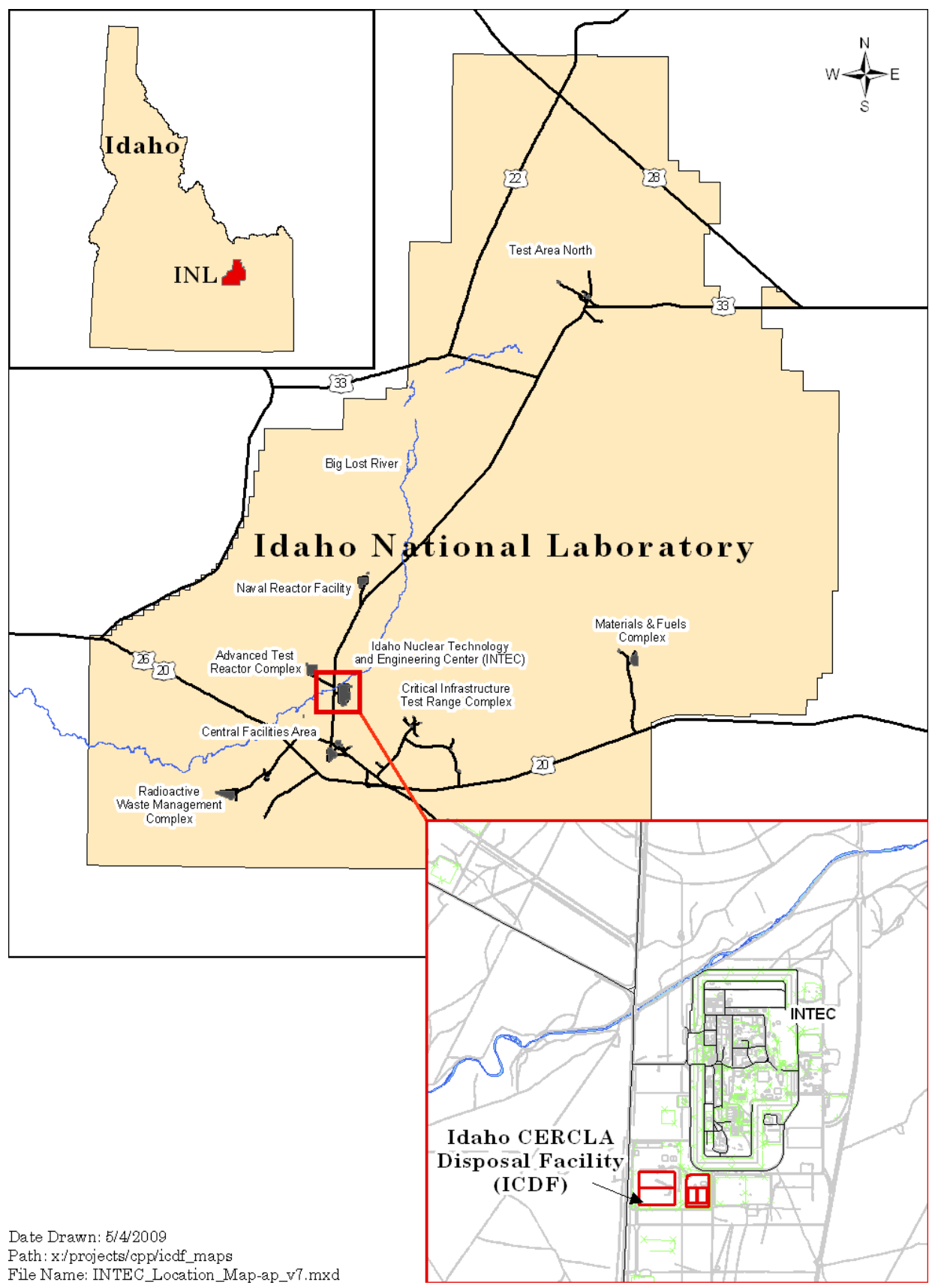

Figure 34. Location of the Idaho CERCLA Disposal Facility complex. 
Table 16. Summary of primary potential dose contributions to predicted doses from the remote-handled low-level waste facility.

\begin{tabular}{|c|c|c|c|}
\hline Source & Nuclide(s) & $\begin{array}{c}\text { Peak Dose } \\
\text { (mrem/year EDE) }\end{array}$ & $\begin{array}{l}\text { Time of Peak Dose } \\
\text { (CY) }\end{array}$ \\
\hline INTEC soils $^{\mathrm{a}}$ & U-234 & $0.224^{\mathrm{b}}$ & About $43750^{c}$ \\
\hline ICDF & Mostly C-14 & 0.584 & 8368 \\
\hline Tank Farm & Mostly I-129 & 1.40 & About 2900 \\
\hline Site 34 RH-LLW & Mostly C-14 & 1.61 & 4018 \\
\hline \multicolumn{2}{|c|}{$\begin{array}{l}\text { Predicted peak dose after RH-LLW operations } \\
\text { cease in } 2067 \text { and time of peak }\end{array}$} & $1.61<$ dose $<3.59^{d}$ & 2900 to 8368 \\
\hline \multicolumn{4}{|c|}{$\begin{array}{l}\text { a. INTEC soils evaluated as part of OU 3-13 and OU 3-14. } \\
\text { b. Dose scaled from the NRF reanalysis of U-234 (see Table 15). } \\
\text { c. Based on the U-234 peak time from the NRF reanalysis (Appendix A). } \\
\text { d. } 3.59 \mathrm{mrem} / \text { year is the sum of doses from ICDF, Tank Farm, and Site } 34 \text { RH-LLW facility assuming all peaks } \\
\text { occur at the same time and place. }\end{array}$} \\
\hline
\end{tabular}

Based on potential dose contributors to the RH-LLW facility at Site 34, it is very unlikely that doses from OU 3-14 will overlap in time to any great extent with the peak dose from the RH-LLW facility at Site 34. However, peak doses from ICDF and the Tank Farm Facility occur closer in time to the RH-LLW peak dose; therefore, they could potentially overlap and contribute to an increase in the dose. If the peak doses from ICDF and the Tank Farm Facility were added to the peak dose from Site 34, the total dose would be $3.59 \mathrm{mrem} / \mathrm{year}$. However, given that the range of peak times is about 5,500 years $(2,900$ to 8,368 ), it is very likely that the combined dose will be less than $3.59 \mathrm{mrem} / \mathrm{year}$. And even though these facilities are relatively close together, there will be dilution that will make the combined impact less than the sum of the peak doses calculated immediately downgradient from each facility.

\subsection{Far-Field Impacts}

Operable Unit 10-08 addressed the potential for commingling of contaminant plumes from primary INL facilities using a subregional scale, three-dimensional flow and transport model of the Snake River Plain Aquifer. Results were combined to obtain the isopleths for one-tenth the MCL for each contaminant. The following contaminants had simulated concentrations less than one-tenth the MCL in 2005: Np-237, Tc-99, chromium, methylene chloride, tetrachloroethene, and trichloroethene.

For those contaminants that resulted in concentrations above one-tenth the MCL, individual facility isopleths were combined to determine if any portion of the plumes overlapped. Year 2005 was simulated because data using ultralow-level laboratory detection methods were available to compare to modeling results. Future plume overlap was simulated to the year 2095. The only strict overlap is the tritium (H-3) plumes in 2005 from the ATR Complex (Waste Area Group 2) and INTEC (Waste Area Group 3) sources and nitrate in 2005 for INTEC (Waste Area Group 3) and the Central Facility Area (Waste Area Group 4) sources. The model predicts no overlapping plumes in 2095.

The sum of the simulated individual facility plume concentrations for all beta-emitting radionuclides divided by their respective MCLs are superimposed on one contour plot for 2005 (Figure 35) and 2095 (Figure 36). The isopleth for one-tenth the MCL is shown in the figures to delineate areas of simulated commingled plumes. Plumes from the ATR Complex (Waste Area Group 2), INTEC (Waste Area Group 3), and RWMC (Waste Area Group 7) are all shown in Figures 35 and 36. The 2005 results were dominated by tritium (H-3) and the 2095 results were predominantly influenced by I-129. 


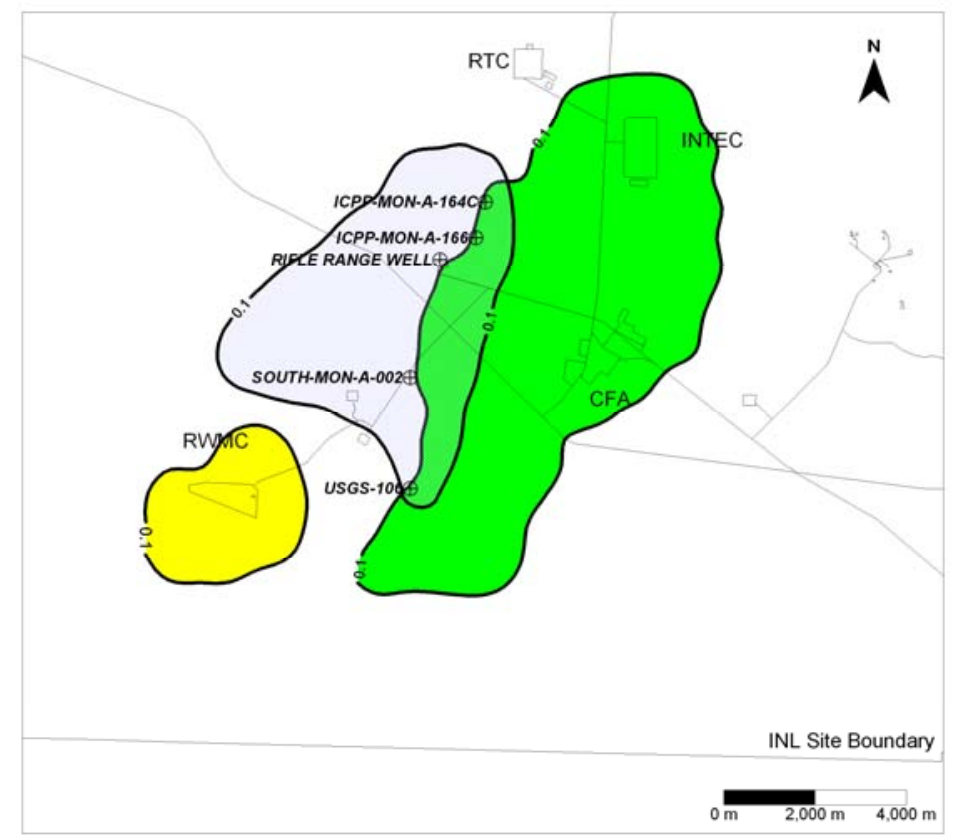

Figure 35. Sum of simulated beta-emitting radionuclide concentrations divided by respective drinking water limits for 2005. Note 1: light blue = Advanced Test Reactor Complex; green $=$ Idaho Nuclear Technology and Engineering Center; yellow = Radioactive Waste Management Complex. Note 2: Data from monitoring wells do not indicate commingling of contaminants. Figure is from DOE-ID (2008).

In 2005, the model predicted that an area of commingling should occur between the Waste Area Group 2 plume and the Waste Area Group 3 plume. However, from data taken from the four monitoring wells in this area there is no evidence of commingled plumes between the ATR Complex and INTEC. Figure 36 shows the sum of simulated beta-emitting radionuclides scaled to drinking water limits for year 2095. The model predicts that there is no commingling at that time.

Commingling beyond the year 2095 was not evaluated for the CERCLA plumes because each individual facility is responsible for ensuring concentrations originating at each facility are below MCLs. However, radionuclides originating from ICDF are conservatively predicted to arrive in the aquifer after the year 3018. The delayed arrival from ICDF will result in part because of the well-mixed soilradionuclide waste form and, in part, because of the infiltration-reducing engineered cover. Radionuclide arrival in the aquifer from the proposed RH-LLW disposal facility also will be delayed in time, in part because of the cement-steel-sand vault system and because of the infiltration-reducing engineered cover. The timeline for arrival of radionuclides to the aquifer from the proposed RH-LLW disposal facility will be more likely to coincide with the arrival of radionuclides from ICDF for similar reasons. 


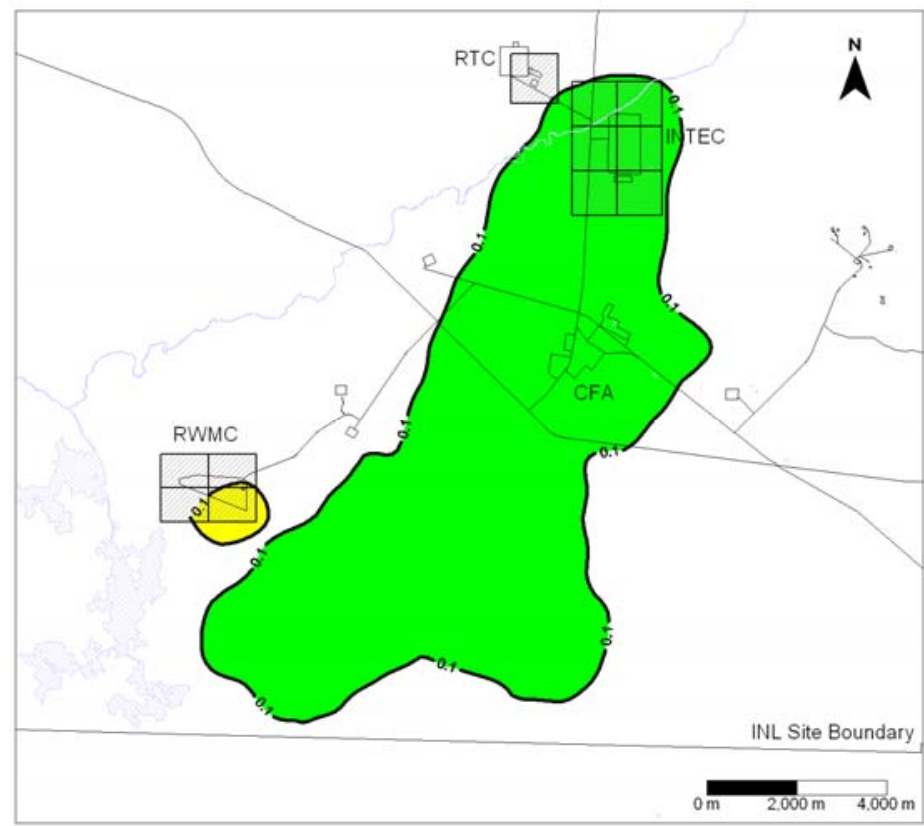

Figure 36. Sum of simulated beta-emitting radionuclide concentrations divided by respective drinking water limits for 2095. Note 1: Light blue = Advanced Test Reactor Complex; green $=$ Idaho Nuclear Technology and Engineering Center; yellow = Radioactive Waste Management Complex. Figure is from DOE-ID (2008).

\subsection{Composite Impacts Summary}

For Site 5, it is very unlikely that either the ATR Complex or NRF will increase the dose over and above what is predicted for the RH-LLW facility ( $0.674 \mathrm{mrem} / \mathrm{year})$. For Site 34, it is possible that radionuclides originating from historical releases at INTEC, ICDF, and the Tank Farm Facilities could comingle in the aquifer with those originating from the proposed RH-LLW disposal facility and increase the overall dose above what is predicted for just Site 34 (1.56 mrem/year). However, it is very unlikely that the total doses from all releases would exceed the DOE Order 435.1 limit of $30 \mathrm{mrem} / \mathrm{year}$ at either site. Conservative worst-case analysis suggests that the dose would be less than $3.59 \mathrm{mrem} / \mathrm{yr}$ at its peak. Nevertheless, the overall impacts are expected to be greater downgradient of Site 34 than of Site 5 .

\section{SUMMARY}

This analysis was prepared to support the National Environmental Policy Act environmental assessment for the top two candidate sites for the INL RH-LLW disposal facility and an estimated 50-year radionuclide inventory. Groundwater impacts have been analyzed using a four-step analysis approach. This assessment compared the predicted groundwater screening concentrations to the maximum contaminant levels for drinking water. The results show that for all radionuclides, the maximum predicted screening concentrations (using successively less conservative approaches and models) were less than the maximum contaminant levels for both Site 5 and Site 34. The results also show the groundwater all-pathways EDE for both sites is less than the dose limit set forth in DOE Order 435.1. An evaluation of 
composite impacts showed that Site 5 is preferable to Site 34, based on the potential for commingling of groundwater contamination with other facilities.

\section{REFERENCES}

40 CFR 141, "National Primary Drinking Water Regulations," Code of Federal Regulations, June 2010.

42 USC § 4321 et seq., "National Environmental Policy Act of 1969 (NEPA),” United States Code, January 1970.

Adler Flitton, M. K., M. E. Delwiche, and T. S. Yoder, 2011, Long Term Corrosion/Degradation Test Twelve Year Results-DRAFT, RPT-750, Idaho Cleanup Project, Idaho National Laboratory.

Appelo, C. A. J. and A. Willemsen, 1987, "Geochemical Calculations and Observations on Salt Water Intrusions, I. A Combined Geochemical/Mixing Cell Model,” Journal of Hydrology, 94, pp. 313-330.

Baes, C. F. III and R. D. Sharp, 1983, “A Proposal for Estimation of Soil Leaching and Leaching Constants for Use in Assessment Models," Journal of Environmental Quality, Vol. 12, No. 1, pp. 17-28.

Cecil, L. D., J. R. Pittman, T. M. Beasley, R. L. Michel, P. W. Kubik, P. Sharma, U. Fehn, and H. Gove, 1992, "Water Infiltration Rates in the Unsaturated Zone at the Idaho National Engineering Laboratory Estimated by Chlorine-36 and Tritium Profiles, and Neutron Logging," in Proceedings of the $7^{\text {th }}$ International Symposium on Water-Rock Interactions, WRI-7, Y. K. Kharaka and A. S. Meest, eds., Park City, Utah, July 13-18, 1992.

Codell, R. B., K. T. Key, and G. Whelan, 1982, A Collection of Mathematical Models for Dispersion in Surface Water and Groundwater, NUREG-0868, U.S. Nuclear Regulatory Commission, June 1982.

Codell, R. B., K. T. Key, and G. Whelan, 1983, “Transport of Radionuclides in Groundwater,” in Radiological Assessment, NUREG/CR-3332, J. E. Till and H. R. Meyer, eds., U.S. Nuclear Regulatory Commission, Washington, DC, 1983.

Dames and Moore, 1992, Remedial Investigation Report for the Test Reactor Area Perched Water System (Operable Unit 2-12), EGG-WM-10002, Revision 0, Idaho National Engineering and Environmental Laboratory, June 1992.

DOE, 1995, Settlement Agreement, U. S. Department of Energy, U.S. Department of the Navy, and the State of Idaho.

DOE-ID, 1994, Track 2 Sites: Guidance for Assessing Low Probability Hazard Sites at the INEL, DOE/ID-10389, U.S. Department of Energy Idaho Operations Office, January 1994.

DOE-ID, 1997a, Comprehensive Remedial Investigation/Feasibility Study for the Idaho Test Reactor Area Operable Unit 2-13 at the Idaho National Engineering and Environmental Laboratory, DOE/ID-10531, U.S. Department of Energy Idaho Operations Office.

DOE-ID, 1997b, Comprehensive Remedial Investigation/Feasibility Study for the Idaho Chemical Processing Plant Operable Unit 3-13 at the INEEL-Part A, DOE/ID-10534, U.S. Department of Energy Idaho Operations Office. 
DOE-NR, 1998, Final Record of Decision, Naval Reactors Facility, Operable Unit 8-08, Idaho National Engineering and Environmental Laboratory, Idaho Falls, Idaho, Administrative Record No. AR5.1-10544, DOE Naval Reactors Idaho Branch Office; EPA, Region 10; Idaho Department of Health and Welfare, Division of Environmental Quality, September 1998.

DOE-ID, 1999, Final Record of Decision Idaho Nuclear Technology \& Engineering Center, Operable Unit 3-13, DOE/IC-10660, U.S. Department of Energy Idaho Operations Office, October 1999.

DOE, 2002, Idaho High-Level Waste and Facilities Disposition Final Environmental Impact Statement, DOE/EIS-0287, U.S. Department of Energy, September 2002.

DOE-ID, 2003a, First Five-Year Review Report for the Test Reactor Area, Operable Unit 2-13, at the Idaho National Engineering and Environmental Laboratory, DOE/ID-11099, Rev. 0, U.S. Department of Energy Idaho Operations Office, September 2003.

DOE-ID, 2003b, Performance Assessment for the INEEL CERCLA Disposal Facility Landfill (Draft), DOE/ID-10978, Rev. 1, Draft A, U.S. Department of Energy Idaho Operations Office, March 2010.

DOE-ID, 2003c, Phase I Monitoring Well and Tracer Study Report for Operable Unit 3-13, Group 4, Perched Water, DOE/ID-10967, U.S. Department of Energy Idaho Operations Office, June 2003.

DOE-ID, 2003d, Performance Assessment for the Tank Farm Facility at the Idaho National Engineering and Environmental Laboratory, Volume 1, DOE/ID-10966, U.S. Department of Energy Idaho Operations Office, April 2003.

DOE-ID, 2004, Spatial Variability of Sedimentary Interbed Properties Near the INTEC at the INEEL, Knobel, L. L., USGS Water Resources Investigation Report 03-4142, also as DOE/ID-22187, U.S. Department of Energy Idaho Operations Office, 2004.

DOE-ID, 2005a, Response to the First Five-Year Review Report for the Test Reactor Area, Operable Unit 2-13, at the Idaho National Engineering and Environmental Laboratory, DOE/NE-ID-11189 U.S. Department of Energy Idaho Operations Office.

DOE-ID, 2005므, Waste Area Group 10, Operable Unit 10-08, Remedial Investigation/Feasibility Study Annual Status Report for Fiscal Year 2004, DOE/NE-ID-11198, U.S. Department of Energy Idaho Operations Office, March 2005.

DOE-ID, 2006a, Operable Unit 3-14 Tank Farm Soil and Groundwater Remedial Investigation/Baseline Risk Assessment, DOE/ID-11227, U.S. Department of Energy Idaho Operations Office, April 2006.

DOE-ID, 2006b, Remedial Investigation and Baseline Risk Assessment for Operable Unit 7-13/14, DOE/ID-11241, Rev. 0, U.S. Department of Energy Idaho Operations Office, May 2006.

DOE-ID, 2007a, Performance Assessment for the RWMC Active Low-Level Waste Disposal Facility at the Idaho National Laboratory Site, DOE/NE-ID-11243, U.S. Department of Energy Idaho Operations Office, September 2007. 
DOE-ID, 2007b, Record of Decision (ROD) for Tank Farm Soil and Idaho Nuclear Technology and Engineering Center (INTEC) Groundwater, Operable Unit (OU) 3-14, DOE/ID-11296, Rev. 0, U.S. Department of Energy Idaho Operations Office.

DOE-ID, 2008, Operable Unit 10-08 Sitewide Groundwater and Miscellaneous Sites Remedial Investigation/Baseline Risk Assessment (RI/BRA), DOE/ID-11332, U.S. Department of Energy Idaho Operations Office, April 2008.

DOE-ID, 20102011, Performance Assessment for the Idaho CERCLA Disposal Facility (DRAFT), DOE/ID-10978, Rev. 2, U.S. Department of Energy Idaho Operations Office.

DOE Order 435.1, "Radioactive Waste Management," Change 1, U.S. Department of Energy, July 1999.

Doornbos, M. H, J. L. Mattick, D. L. McElroy, L. V. Street, C. S. Blackmore, and C. A. Dicke, 1991, Environmental Characterization Report for the Test Reactor Area, EGG-WM-9690, Rev. 0, Idaho National Engineering Laboratory, September 1991.

ECAR-851, 2010, "Estimate of the Radionuclide Content of Future Resins Generation at ATR from 2016 to 2065," Engineering Calculation and Analysis Report, Idaho National Laboratory, May 2010Dec 2011.

ECAR-854, 2010, "Estimate of the Radionuclide Content of Future Activated Metal Generation at ATR from 2016 to 2065," Engineering Calculation and Analysis Report, Idaho National Laboratory, January 2010.

ECAR-904, 2010, “A Methodology for Retrofitting Source-Terms to Previously Inadequately Characterized EBR-II Irradiated Reactor Hardware as Waste (Source Term and Volume Estimate for MFC Generated Remote Handled Low Level Waste from 2016 to 2065," Engineering Calculation and Analysis Report, Idaho National Laboratory, June 2010.

ECAR-967, 2010, "Source Term and Volume Estimate for MFC Generated Remote Handled Low Level Waste from 2016 to 2065," Engineering Calculation and Analysis Report, Idaho National Laboratory, June 2010.

ECAR-1370, 2011, "Air Pathway Assessment for the INL Remote-Handled Low-Level Waste Disposal Project," Engineering Calculation and Analysis Report, Rev. 1, Idaho National Laboratory, September 2011.

EPA, 1999, Cancer Risk Coefficients for Environmental Exposure to Radionuclides; Federal Guidance Report 13, EPA402-R-99-001, U.S. Environmental Protection Agency, Washington, DC, September 1999.

EPA, 2002, Cancer Risk Coefficients for Environmental Exposure to Radionuclides; Federal Guidance Report 13, CD Supplement, EPA 402-C-99-001, Revision 1, U. S. Environmental Protection Agency, Washington, DC, April 2002.

Gardner, R. H., R. V. O’Neill, J. B. Mankin, and D. Kumer, 1980, "Comparative Error Analysis of Six Predator-Prey Models," Ecology, 61, pp. 323-332. 
Harvego, L., J. Connolly, L. Peterson, B. Orr, and B. Starr, 2010, Siting Study for the Remote-Handled Low-Level Waste Disposal Facility, INL/EXT-07-12902, Idaho National Laboratory, January 2010.

Hahn, G. J. and W. Q. Meeker, 1991, Statistical Intervals A Guide for Practitioners, New York: John Wiley and Sons Incorporated, August 1991.

Helm-Clark, C., S. Ansley, T. McLing, and T. Wood, 2005, Borehole and Well Middle-1823 and Its Relationship to the Stratigraphy of the South-Central Idaho National Laboratory, ICP/EXT-05-00790, March 2005.

Hoffman, F. O. and R. H. Gardner, 1983, "Evaluation of Uncertainties in Radiological Assessment Models," in Radiological Assessment, J. E. Till and H. R. Meyer, eds., NUREG CR-3332, U.S. Nuclear Regulatory Commission, September 1983.

ICRP 72, 1995, Age-dependent Doses to the Members of the Public from Intake of Radionuclides - Part 5 Compilation of Ingestion and Inhalation Coefficients, ICRP Publication 72, Annals of the ICRP Volume 26(1).

INL, 2010a, Conceptual Design Report for the Remote-Handled Low-Level Waste Disposal Facility, INL/EXT-07-12901, Revision 3, Idaho National Laboratory, October 2010.

INL, 2010b, Evaluation of Sedimentary Structure Near the Advance Test Reactor Complex at the Idaho National Laboratory (DRAFT), INL/EXT-10-18762, Idaho National Laboratory.

INL, 2010c, Assessment of Potential Flood Events and Impacts at INL's Proposed Remote-Handled Low-Level Waste Disposal Facility Sites, INL/EXT-10-18191, Idaho National Laboratory.

INL, 2010e2011, Assessment of Geochemical Environment for the Proposed INL Remote-Handled Low-Level Waste Disposal Facility(DRAFT), INL/EXT-10-19385, Rev. 1, Idaho National Laboratory.

Jenkins, T., 2001, U.S. Department of Energy Idaho Operations Office, letter, to Marty Doornbos, Idaho National Engineering and Environmental Laboratory, July 3, 2001, "Kd Values for INTEC Groundwater Modeling," EM-ER-01-115.

Kennedy, W. E. and D. L. Strenge, 1992, Residual Radioactive Contamination from Decommissioning, NUREG/CR-5512, U.S. Nuclear Regulatory Commission.

Levenspiel, O. and K. B. Bischoff, 1963, "Patterns of Flow in Chemical Process Vessels" in T. B. Drew, J. W. Hoopes, Jr., and T. Vermeulen Eds., Advances in Chemical Engineering, Vol. 4, Academic Press, New York, 95-198.

Magnuson, S. O., 1995, Inverse Modeling for Field-Scale Hydrologic and Transport Parameters of Fractured Basalt, INEL-95/0637, Idaho National Engineering Laboratory.

Martian, P., 1995, UNSAT-H Infiltration Model Calibration at the Subsurface Disposal Area, Idaho National Engineering Laboratory, INEL-95/0596, Idaho National Engineering Laboratory. 
Martian, P. and S. O. Magnuson, 1994, A Simulation Study of Infiltration Into Surficial Sediments at the Subsurface Disposal Area, Idaho National Engineering Laboratory, EGG-WM-11250, Idaho National Engineering and Environmental Laboratory.

Mattson, E., M. Ankeny, S. Dwyer, N. Hampton, G. Matthern, B. Pace, A. Parsons, M. Plummer, S. Reese, and J. Waugh, 2004, Preliminary Design for an Engineered Surface Barrier at the Subsurface Disposal Area, ICP/EXT-04-00216, Idaho National Engineering and Environmental Laboratory, Idaho Completion Project.

Nagata, P. K. and J. Banaee, 1996, Estimation of the Underground Corrosion Rates for Low-Carbon Steels; Types 304 and 316 Stainless Steels; and Inconel 600, 601, and 718 Alloys at the Radioactive Waste Management Complex, INEL-096/098, Idaho National Engineering Laboratory, July 1996.

NBS, 1963, Maximum Permissible Body Burdens and Maximum Permissible Concentrations of Radionuclides in Air or Water for Occupational Exposure, National Bureau of Standards Handbook 69, U.S. Department of Commerce, Amended August 1963.

NCRP, 1996, Screening Models for Releases of Radionuclides to Atmospheric, Surface Water, and Ground - Worksheets, NCRP Report No. 123 II (Vol. 2), National Council on Radiation Protection and Measurement.

NRF, 2011, Updated Long Range Radioactivity Estimate for NRF RH-LLW, DRAFT Letter Report NRF-WS-603 from Noah Rupp, Naval Reactors Facility, Bechtel Marine Propulsion Corporation, Bettis Atomic Power Laboratory, to Naval Reactors Operations Manager, U.S. Department of Energy, Idaho Branch Office, April 11, 2011.

Oztunali, O. I. and G. W. Roles, 1986, Update of Part 61 Impacts Analysis Methodology, NUREG/CR-4370, Vol. 1, U.S. Nuclear Regulatory Commission.

Rood, A. S., 2003, GWSCREEN: A Semi-Analytical Model for Assessment of the Groundwater Pathway from Surface or Buried Contamination, Theory and User's Manual, Version 2.5 INEEL/EXT-98-00750, Idaho National Engineering and Environmental Laboratory, April 2003.

Rood, A. S., 2005, Mixing Cell Model: A One-Dimensional Numerical Model for Assessment of Water Flow and Contaminant Transport in the Unsaturated Zone, ICP/EXT-05-00748, Rev. 0, Idaho Completion Project, Idaho Falls, March 2005.

Shaeffer, D. L., 1980, "A Model Evaluation Methodology Applicable to Environmental Assessment Models," Ecology Modeling, 8, pp. 275-295.

Schwarz, G. and F. O. Hoffman, 1981, "Imprecision of Dose Predictions for Radionuclides Released to the Environment: An Application of a Monte Carlo Simulation Technique," Environment International, 4, pp. 289-297.

Scott, S. J. and D. M. Hetrick, 1994, The New SESOIL User's Guide, PUBL-SW-200-94, Science and Technology Management Inc., Brookfield, WI, distributed by the Radiation Safety Information Computational Center, Oak Ridge National Laboratory, Oak Ridge, Tennessee, 1994.

Shanahan, P. and D. R. F. Harleman, 1984, “Transport in Lake Water Quality Modeling,” Journal of Environmental Engineering, 110(1), pp. 42-57. 
van Genuchten, M. Th., 1980, “A Closed-form Equation for Predicting the Hydraulic Conductivity of Unsaturated Soils,” Soil Sci. Soc. Am J., 44, 892-898.

Van Ommen, H. C., 1985, “The Mixing Cell Concept Applied to Transport of Non-Reactive and Reactive Components in Soils and Groundwater," Journal of Hydrology, 78, pp. 201-213.

Westinghouse, 1997, Final NRF Comprehensive Remedial Investigation/Feasibility Study, Waste Area Group 8, Naval Reactors Facility, Idaho Falls, Idaho, DOE/ID-10432, Volumes 1 through 3, October 1997.

Whelan, G., J. P. McDonald, and C. Sato, 1996, Multimedia Environmental Pollutant Assessment System (MEPAS) Groundwater Pathway Formulations, PNNL-10907, Pacific Northwest National Laboratory, June 1996.

Wood, T. R., C. M. Helm-Clark, H. Huang, S. Magnuson, T. McLing, B. Orr, M. J. Rohe, M. A. Plummer, R. Podgorney, E. Whitmore, and M. S. Roddy, 2007, Development Report on the Idaho National Laboratory Sitewide Three-Dimensional Aquifer Model, INL/EXT-13337, U.S. Department of Energy Idaho Operations Office, September 2007.

Yu, C., A. J. Zielen, J. J. Cheng, D. J. LePoire, E. Gnanapragasam, S. Kamboj, J. Arnish, A. Wallo III, W. A. Williams, and H. Peterson, 2001, User's Manual for RESRAD Version 6, ANL/EAD-4, Environmental Assessment Division, Argonne National Laboratory, July 2001.

Zvirin, T., and R. Shinnar, 1976, "Interpretation of Internal Tracer Experiments and Local Sojourn Time Distributions," International Journal of Multiphase Flow, 2, pp. 495-520. 


\section{Appendix A}

Assessment of Groundwater Impacts from Sources Upgradient of the Remote-Handled Low-Level Waste Disposal Facility Candidate Site 5 


\section{CONTENTS}

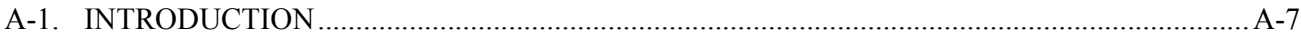

A-2. IDENTIFICATION OF UPGRADIENT SOURCES .............................................................. A-7

A-2.1 Residual Radionuclide Sources at the Naval Reactors Facility ...................................... A-8

A-2.2 Residual Radionuclide Sources at the Advanced Test Reactor Complex .......................... A-11

A-2.3 Relevance to the Proposed Remote-Handled Low-Level ................................................. A-13

A-2.4 Waste Disposal Facility Candidate Site 5 …..................................................................... A-13

A-3. MODEL USED IN THE PREVIOUS GROUNDWATER IMPACTS ANALYSES.................. A-13

A-4. SUMMARY OF THE FINAL COMPREHENSIVE RISK ASSESSMENT MODEL FOR THE NAVAL REACTORS FACILITY ……................................................................ A-14

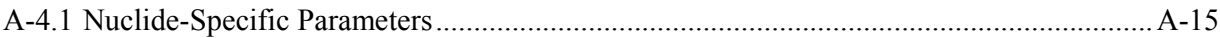

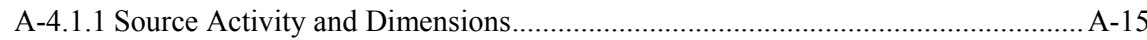

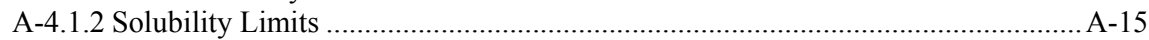

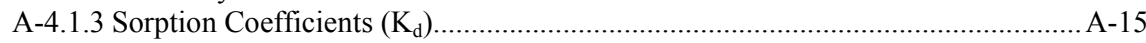

A-4.1.4 Daughter Products....................................................................... A-16

A-4.1.5 Risk and Dose Coefficients ............................................................................. A-16

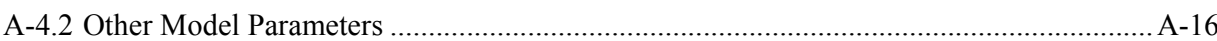

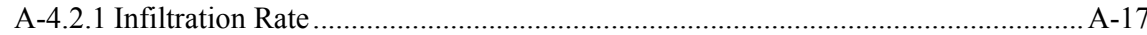

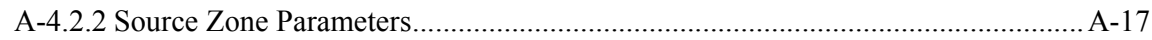

A-4.2.3 Unsaturated Zone Parameters ................................................................. A-17

A-4.2.4 Aquifer Parameters ......................................................................... A-17

A-4.3 Reproducing the Naval Reactors Facility Predicted Cumulative Results ........................ A-18

A-5. SUMMARY OF THE FINAL COMPREHENSIVE RISK ASSESSMENT MODEL FOR THE ADVANCED TEST REACTOR COMPLEX ............................................................... A-18

A-5.1 Nuclide-Specific Parameters .......................................................................................... A-19

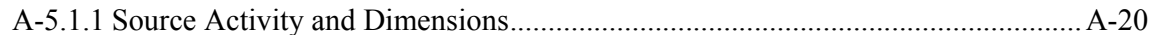

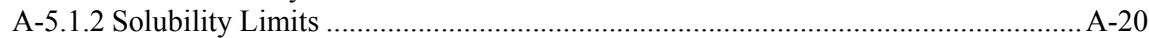

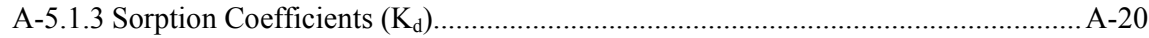

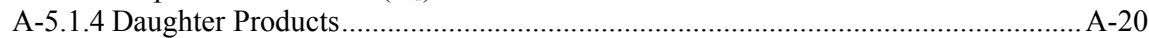

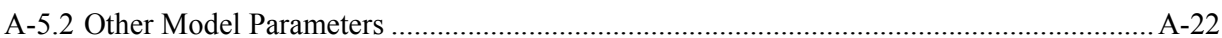

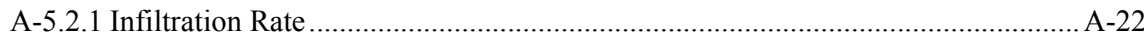

A-5.2.2 Source Zone Parameters............................................................................ A-22

A-5.2.3 Unsaturated Zone Parameters ………............................................................ A-23 
A-6.1 Infiltration Rates

A-6.2 Relative Sediment Abundance

A-24

A-6.3 Sedimentary Interbed Properties .............................................................. A-25

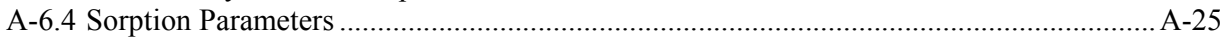

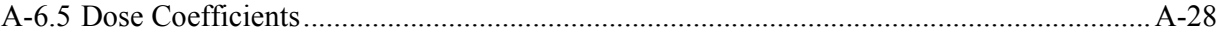

A-7. COMPUTATION OF DOSE FOR TIME PERIODS OF INTEREST TO THE

REMOTE-HANDLED LOW-LEVEL WASTE DISPOSAL FACILITY

A-7.1 Evaluation of the All-Pathways Effective Dose Equivalent for the Naval Reactors Facility

A-7.2 Evaluation of All-Pathways Effective Dose Equivalent for the Advanced Test Reactor Complex.

\section{FIGURES}

A-1. Distribution of contaminated sites with long-term groundwater ingestion risk greater than $1 \times 10^{-7}$ at the Naval Reactors Facility

A-2. Conceptual model of transport implemented for the Naval Reactors Facility A-14

\section{TABLES}

A-1. Radionuclides by source unit for the Naval Reactors Facility Remedial Investigation/Feasibility Study with GWSCREEN source dimensions and activity

A-2. Inventory by radionuclide in surficial soils and perched water at the Advanced Test Reactor Complex

A-3. Nuclide-specific parameters used in the Naval Reactors Facility comprehensive remedial investigation and feasibility study GWSCREEN analysis

A-4. Non-nuclide specific parameters used in the Naval Reactors Facility comprehensive remedial investigation/feasibility study

A-5. GWSCREEN results for the Naval Reactors Facility given in Westinghouse (1997) and reproduced using GWSCREEN version 2.5 (01-23-07) 
A-6. Nuclide-specific parameters used in the Operable Unit 2-13 comprehensive remedial investigation and feasibility study for the Advanced Test Reactor Complex.....

A-7. Non-nuclide-specific parameters used in the Advanced Test Reactor Complex comprehensive remedial investigation

A-8. Distribution coefficients recommended and currently in use as screening values

A-9. Screening level sorption parameters for parents and daughter products

A-10. Distribution coefficients recommended for use by the remote-handled low-level waste disposal facility for key radionuclides also present in upgradient sources compared to those used in previous remedial investigations and feasibility studies.

A-11. Hydraulic parameters used to represent flow in the source zone and vadose zone models

A-12. Input parameters for the Naval Reactors Facility re-analysis

A-13. Predicted peak radionuclide groundwater concentrations for the re-analysis of the comprehensive groundwater impacts at the Naval Reactors Facility

A-14. Predicted all-pathways dose for the re-analysis of cumulative groundwater impacts at the Naval Reactors Facility.

A-15. Results of radionuclide screening for the Advanced Test Reactor Complex surface soils inventories

A-16. Input parameters for the re-analysis of contaminated soils sources at the Advanced Test Reactor Complex

A-17. Predicted peak radionuclide groundwater concentrations and all-pathways dose for the re-analysis of Advanced Test Reactor Complex surface soil contamination

A-18. Input parameters for the re-analysis of perched water at the Advanced Test Reactor Complex

A-19. Predicted peak radionuclide groundwater concentrations and all-pathways EDE for the re-analysis of Advanced Test Reactor perched water contamination, using MCM and GWSCREEN, using revised sediment and basalt properties and $\mathrm{K}_{d}$ values in A-9 


\section{Appendix A Assessment of Groundwater Impacts from Sources Upgradient of the Remote-Handled Low-Level Waste Disposal Facility Candidate Site 5}

\section{A-1. INTRODUCTION}

Impacts to groundwater concentrations at the INL RH-LLW disposal facility proposed Site 5 location from upgradient historical releases of radionuclides are assessed in this appendix. Sources upgradient of proposed Site 5 include those at NRF and the ATR Complex (formerly known as the Test Reactor Area). Unmitigated releases from both facilities have been previously analyzed during their respective CERCLA investigations as reviewed in this appendix. These impacts are verified in the analysis of this appendix in support of the cumulative groundwater impacts analysis for the proposed onsite alternative Site 5 location.

The purpose of each of the CERCLA baseline risk assessments conducted at NRF and the ATR Complex was to evaluate risk to potential receptors, and if the risk could be shown to be low using even very conservative parameters that likely overestimated concentrations and risk, then additional refinement of various input parameters to obtain less conservative, possibly more realistic, results was not needed. For example, NRF typically used maximum concentrations of constituents found during sampling events even if the constituent was only detected a few times in the many samples collected, and very conservative sorption parameters were used that essentially treated sedimentary interbeds as crushed basalt. In the ATR Complex, high infiltration rates were used in the model, which lead to simulated rapid radionuclide transport through the vadose zone with very little radioactive decay along the flow path. In addition, the CERCLA baseline risk assessments were conducted to determine whether or not mitigation was required to reduce risk. Subsequent actions have been taken for higher risk sites (i.e., removal of sources and construction of engineered covers) to reduces overall risks. Reducing overall risks also reduces potential groundwater impacts allowing State of Idaho and federal groundwater limits to be met. These mitigative measures were not included in the baseline risk assessments, and are not factored in to the following analyses in order to allow direct verification of the baseline risk assessment models.

Verification of these upgradient unmitigated groundwater concentration impacts is necessary because (1) CERCLA evaluations conducted for some low-hazard facilities at INL were terminated prior to 1000 years for radionuclides reaching estimated peak concentrations more than 1,000 years from the initial release; (2) DOE Order 435.1 requires that impacts be analyzed for new facilities through 1,000 years after facility closure or to peak dose; (3) the assessments performed for the upgradient facilities were conducted prior to revision of the ingestion dose coefficients by EPA; and (4) the analyses conducted for upgradient facilities were performed prior to the completion of CERCLA investigations at INTEC (DOE-ID 1997a, DOE-ID 2006a) and the Subsurface Disposal Area at RWMC (DOE-ID 2006b). The latter analyses have provided a more complete understanding of flow and sorptive processes in the vadose zone and aquifer and are currently being used to guide model parameterization across INL.

\section{A-2. IDENTIFICATION OF UPGRADIENT SOURCES}

There are only two INL complexes located in the generally understood aquifer flow path upgradient of the proposed Site 5 location (Wood et al. 2007). Of these, NRF is located approximately 5 miles north of Site 5, and the ATR Complex is 3/4 mile north of Site 5. Sources of previously released radionuclides at these facilities are detailed in their respective Comprehensive Remedial Investigations and Feasibility Studies (RI/FS). For NRF this is documented in Westinghouse (1997) while the ATR Complex is in DOE-ID (1997b). Radionuclides of concern identified by the RI/FSs, the media containing the 
radionuclides, and the source inventory at NRF and the ATR Complex are reproduced in the following subsections.

\section{A-2.1 Residual Radionuclide Sources at the Naval Reactors Facility}

NRF is located on the west-central side of INL, approximately $80 \mathrm{~km}(50 \mathrm{mi})$ west of Idaho Falls. NRF covers $20 \mathrm{~km}^{2}\left(7 \mathrm{mi}^{2}\right)$ of which $33 \mathrm{ha}(80$ acres) are developed. A total of 87 known or suspected contaminant release sites were evaluated under CERCLA at NRF; 74 sites were classified in nine operable units (OUs) and were identified as requiring further study. Thirteen of the 87 sites were evaluated before the 1991 tri-party (U.S. Environmental Protection Agency, State of Idaho, and DOE) Federal Facility Agreement and Consent Order was signed and were not part of an operable unit (OU). These 13 sites were identified as no action sites in the Federal Facility Agreement and Consent Order. Eight of the nine OUs had been investigated prior to the NRF comprehensive RI/FS (Westinghouse 1997). Ten sites in OUs 8-05, 8-06, and 8-07 were addressed under a Record of Decision signed in September 1994, leaving 64 sites to be addressed in the NRF Final Record of Decision. OU 8-08 was the last $\mathrm{OU}$ at NRF to be investigated.

Of the remaining 64 sites, 44 sites are associated with OUs 8-01, - $02,-03,-04$, and -09 . OU 8-08 includes 18 sites that were not previously investigated under other OUs. OU 8-08 sites were grouped together because of similar constituents, release mechanisms, and migration paths. In addition, two sites were not part of an OU since they were identified after the OUs were established. The OU 8-08 sites represent areas where historical controlled releases of low-level radioactive water were discharged and areas where inadvertent releases to the environment occurred because of leaks from corroded piping, leaks in underground concrete basins, surface releases, and cross-contamination of nonradiological systems with radiological systems. The final record of decision addressing these 64 sites at NRF was completed in September 1998 (DOE-NR 1998). The final record of decision and comprehensive RI/FS are references for information provided in this assessment.

As documented in the record of decision, NRF conducted controlled discharges of water contaminated with low levels of radionuclides between 1953 and 1979. Approximately 1.5 billion $(1,500,000,000)$ liters $(417,000,000 \mathrm{gal})$ of water, containing a total of $345.51 \mathrm{Ci}$, were discharged to drainfields, pits, and beds during this time period. The Waste Area Group (WAG) 8 comprehensive RI/FS (Westinghouse 1997) included an assessment of groundwater impacts for each individual site. Based on the individual analyses, the NRF record of decision concluded that the groundwater pathway is not a pathway of concern within a 1,000 year time period at NRF.

A cumulative baseline risk assessment was also performed for NRF (Westinghouse 1997) to determine the overall impact of unmitigated WAG 8 sites on future groundwater receptors. The cumulative baseline risk assessment determined if there were additional risks due to cumulative effects associated with having several individual contaminated sites near one another. The cumulative risk assessment conducted for NRF considered inhalation, groundwater ingestion, and external exposure to radionuclides. Soil ingestion and crop ingestion were evaluated during the individual Track 2 assessments.

Radiologic constituents remaining after applying the screening criteria in the WAG 8 comprehensive RI/FS included C-14, Np-237, Pu-239, Pu-244, U-234, and U-235 found in contaminated surface soils in the S1W Seepage Basin Leaching Pit (8-08-12), S1W Seepage Basin \#4 (8-08-14), S1W Radiography Building Collection Tanks (8-08-16), A1W Leaching Bed (8-08-19), Old Sewage Treatment Plant (8-08-21), Seepage Basin Pump Out Area (8-08-43), and the A1W Processing Building Area Soils (8-08-81) (Column 2, Table A-1). Activities for these radionuclides of concern and total contaminated soil extents are given in Table A-1, Column 3 for each of the source units. The activity corresponds to the peak soil concentration reported for each source unit (from Table 18-4 of Westinghouse 1997). The total contaminated length, width, depth, and volume given in Table A-1 were obtained from the NRF 
comprehensive RI/FS by averaging the individual soil concentrations over their respective contaminated volumes. Distances to the receptors (Table A-1, Column 4) for each of the nuclides varied in the comprehensive NRF RI/FS analysis with explanation for the distances used provided in Westinghouse (1997). Typically, this distance either corresponded to one-half of the source length in the direction of groundwater flow (i.e., to the source boundary. Most of the contaminated areas at NRF are located near the southern NRF fence line as shown in Figure A-1.

Table A-1. Radionuclides by source unit for the Naval Reactors Facility Remedial Investigation/Feasibility Study with GWSCREEN source dimensions and activity.

\begin{tabular}{|c|c|c|c|c|c|c|c|}
\hline Radionuclide & Source Unit* & $\begin{array}{c}\text { Activity } \\
\text { (Ci) }\end{array}$ & $\begin{array}{l}\text { Distance to } \\
\text { Receptor } \\
\text { (m) }\end{array}$ & $\begin{array}{l}\text { Length } \\
\text { (m) }\end{array}$ & $\begin{array}{l}\text { Width } \\
(\mathrm{m})\end{array}$ & $\begin{array}{c}\text { Depth } \\
(\mathrm{m})\end{array}$ & $\begin{array}{c}\text { Volume } \\
\left(\mathrm{m}^{3}\right)\end{array}$ \\
\hline C-14 & $8-08-14 / 8-08-12 B$ & 7.35E-01 & & & & & \\
\hline C-14 & $8-08-12 \mathrm{~A}$ & 2.37E-02 & & & & & \\
\hline C-14 & 8-08-19 & $3.96 \mathrm{E}-02$ & & & & & \\
\hline C-14 & $8-08-43$ & 4.62E-01 & & & & & \\
\hline C-14 & $8-08-81$ & $6.28 \mathrm{E}-02$ & & & & & \\
\hline C-14 Total & & $1.32 \mathrm{E}+00$ & 54.7 & 109.28 & 76.71 & 8.03 & $6.74 \mathrm{E}+04$ \\
\hline Np-237 & $8-08-14 / 8-08-12 B$ & $6.67 \mathrm{E}-02$ & & & & & \\
\hline Np-237 Total & & $6.67 \mathrm{E}-02$ & 290.38 & 91.44 & 70.1 & 8.23 & $5.28 \mathrm{E}+04$ \\
\hline $\mathrm{Pu}-239$ & $8-08-14 / 8-08-12 B$ & 4.22E-02 & & & & & \\
\hline $\mathrm{Pu}-239$ & $8-08-12 \mathrm{~A}$ & $5.44 \mathrm{E}-04$ & & & & & \\
\hline $\mathrm{Pu}-239$ & 8-08-19 & $6.95 \mathrm{E}-03$ & & & & & \\
\hline $\mathrm{Pu}-239$ & $8-08-43$ & $1.18 \mathrm{E}-02$ & & & & & \\
\hline $\mathrm{Pu}-239$ & $8-08-81$ & $1.61 \mathrm{E}-03$ & & & & & \\
\hline Pu-239 Total & & $6.31 \mathrm{E}-02$ & 54.64 & 109.28 & 76.35 & 8.03 & $6.70 \mathrm{E}+04$ \\
\hline $\mathrm{Pu}-244$ & $8-08-21 B$ & $1.77 \mathrm{E}-05$ & & & & & \\
\hline $\mathrm{Pu}-244$ & $8-08-12 \mathrm{~A}$ & $6.53 \mathrm{E}-04$ & & & & & \\
\hline Pu-244 Total & & $6.71 \mathrm{E}-04$ & 87.1 & 174.18 & 3.26 & 3.17 & $1.80 \mathrm{E}+03$ \\
\hline U-234 & 8-08-19 & $2.77 \mathrm{E}-02$ & & & & & \\
\hline U-234 Total & & $2.77 \mathrm{E}-02$ & 290.38 & 60.96 & 15.24 & 3.96 & $3.68 \mathrm{E}+03$ \\
\hline U-235 & $8-08-16$ & $1.54 \mathrm{E}-03$ & & & & & \\
\hline $\mathrm{U}-235$ & $8-08-21 B$ & $3.13 \mathrm{E}-05$ & & & & & \\
\hline U-235 & $8-08-81$ & $3.08 \mathrm{E}-04$ & & & & & \\
\hline U-235 Total & & $1.88 \mathrm{E}-03$ & 24.59 & 49.18 & 43.07 & 3.08 & $6.53 \mathrm{E}+03$ \\
\hline
\end{tabular}



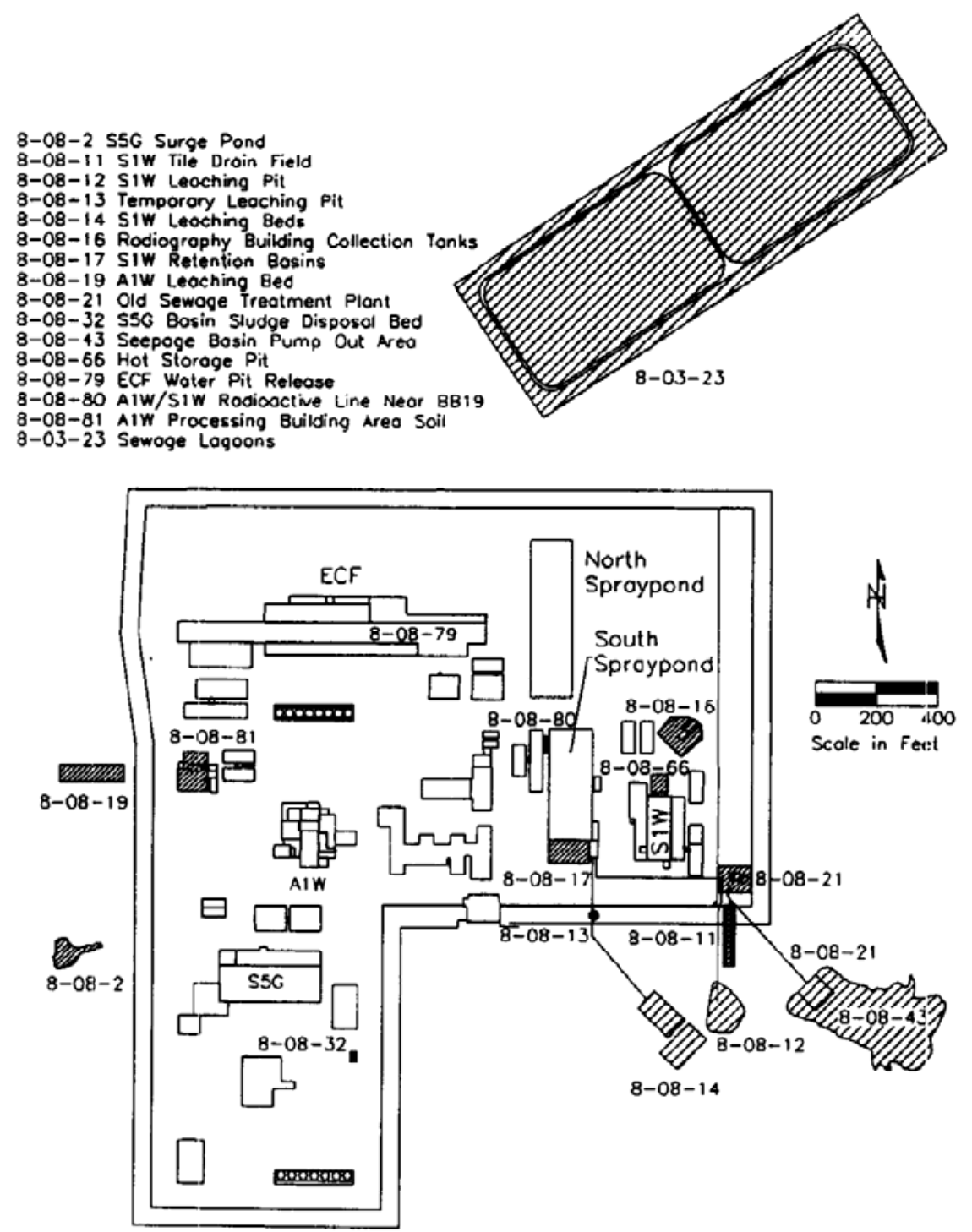

Figure A-1. Distribution of contaminated sites with long-term groundwater ingestion risk greater than $1 \times 10^{-7}$ at the Naval Reactors Facility. 


\section{A-2.2 Residual Radionuclide Sources at the Advanced Test Reactor Complex}

Release sites investigated under CERCLA at the ATR Complex (WAG 2) included pits, tanks, rubble piles, ponds, cooling towers, wells, French drains, spills, and perched water as specified in the Record of Decision for OU 2-13 (DOE-ID 1997c). Eight of the 55 identified release sites within the Test Reactor Area had actual or threatened releases of hazardous substances, which, if not addressed by implementing the response actions specified in the OU 2-13 Record of Decision, could have presented an unacceptable risk to human health or the environment. These sites included four disposal ponds (Warm Waste Pond1952, 1957, and 1964 cells [TRA-03], Chemical Waste Pond [TRA-06], Cold Waste Pond [TRA-08], and the Sewage Leach Pond [TRA-13]), three subsurface contaminant release sites (soil surrounding Hot Waste Tanks at Building 613 [TRA-I5], Tanks 1 and 2 at Building 630 [TRA-19], and the Brass Cap Area), and one area of surficial windblown contamination (Sewage Leach Pond Berms and Soil Contamination Area). The remaining 47 sites either were determined not to present an unacceptable risk to human health or the environment and, therefore, required no further action, or were part of a record of decision preceding the comprehensive OU 2-13 record of decision. These OUs included the: Rubble Piles (no OU specified); Paint Shop Ditch (OU 2-01); Inactive Fuel Tanks (OU 2-02); Miscellaneous Spill Sites (OU 2-03); Petroleum and Polychlorinated Biphenyl Sites and the North Storage Area, including the North Storage Area and Soil Contamination Area (OU 2-04); Hot Waste Tanks (OU 2-05); Rubble Sites (OU 2-06); Cooling Tower Sites (OU 2-07); Materials Test Reactor Canal (OU 2-08); Sewage Treatment Plant (OU 2-09); Retention Basin, Injection Well, Cold Waste Sampling Pit and Sump (OU 2-1 1); Perched Water (OU 2-12); and Hot Tree Site, Engineering Test Reactor Stack, and French Drain Associated with TRA-653 and Diesel Unloading Pit (OU 2-13).

As documented in the comprehensive RI/FS for WAG 2 (DOE-ID 1997b), the groundwater risks were evaluated for the 100 to 1,000-year timeframe under the No Action Alternative. The radionuclides of concern evaluated in the comprehensive RI/FS for WAG 2 are shown in Table A-2 for each of the individual contaminated areas evaluated. The inventory shown in Table A-2 contains the total activity estimated from measurements of contaminated soils and perched water. The soils inventory and soils volumes at each of the sites are listed in Columns 2-12. The total activity across all of the contaminated soils sites is listed in Column 13. As shown by the soil site inventories in Table A-2, the bulk of the inventory is associated with discharges to the warm waste pond (TRA-03).

The inventory listed in Table A-2, Column 14 accounts for radionuclides in the perched water underlying the ATR Complex. This perched water was formed as a result of historical discharges of water into the warm waste pond, chemical pond, and sewage treatment pond. These discharges occurred from 1952 through 1980, with volumes on the order of $200 \mathrm{Mgal} /$ year. Deep discharges of similar volumes during this time also occurred in the TRA Disposal Well. After 1980, the bulk of discharges to the warm waste pond and the disposal well were diverted to the cold waste pond, reducing the warm waste pond volumes to about $50 \mathrm{Mgal} /$ year with discharges to the cold waste pond reduced to about $250 \mathrm{Mgal} / \mathrm{year}$. Downward infiltration of surface discharged water was impeded by a fine silt-clay layer above the first basalt contact that formed the laterally extensive shallow perched water body in the alluvium.

In addition to shallow perched water, there is a deeper perched water body that also formed as the infiltrating water reached another low permeability layer at about $110 \mathrm{ft}$ below land surface. In the deep perched water, alpha-emitting radionuclides analyzed have historically included Am-241, Pu-238, $\mathrm{Pu}-239, \mathrm{U}-234, \mathrm{U}-238$, and $\mathrm{Cm}-244$. Of these, only U-234 and U-238 have been detected in the deep perched water. The sum of U-234 and U-238 concentrations is about $0.006 \mathrm{pCi} / \mathrm{mL}$, excluding well $\mathrm{PW}-14$, which recorded $0.0222 \mathrm{pCi} / \mathrm{mL}$. The natural background concentration for total uranium ranges from 0 to $9 \mathrm{pCi} / \mathrm{L}$, suggesting that uranium detected in the deep perched water is natural as opposed to

anthropogenically derived. All of the constituents listed in Table A-2 were considered to be contaminants of concern in the OU 2-13 comprehensive RI/FS. 
Table A-2. Inventory and source dimensions by radionuclide in surficial soils and perched water at the Advanced Test Reactor Complex.

\begin{tabular}{|c|c|c|c|c|c|c|c|c|c|c|c|c|c|}
\hline \multirow[b]{2}{*}{ Parameter } & \multirow{2}{*}{$\begin{array}{c}\text { TRA-34 } \\
\text { North } \\
\text { storage area } \\
\end{array}$} & \multirow{2}{*}{$\begin{array}{c}\text { TRA-15 } \\
\text { Hot waste } \\
\text { tanks } 2 \text { to } 4 \\
\text { at TRA-613 } \\
\end{array}$} & \multirow{2}{*}{$\begin{array}{l}\text { TRA-19 } \\
\text { Rad tanks } \\
1 \text { and } 4 \text { at } \\
\text { TRA-630 } \\
\end{array}$} & \multirow{2}{*}{$\begin{array}{c}\text { TRA-08 } \\
\text { Cold } \\
\text { waste } \\
\text { pond } \\
\end{array}$} & \multirow{2}{*}{$\begin{array}{l}\text { TRA-13 } \\
\text { Sewage } \\
\text { leach } \\
\text { pond }\end{array}$} & \multirow{2}{*}{\multicolumn{2}{|c|}{\begin{tabular}{c|c}
$\begin{array}{c}\text { TRA-03 } \\
\text { (cells 52 and 57) }\end{array}$ & $\begin{array}{c}\text { TRA-03 } \\
\text { (cell 64) }\end{array}$ \\
\\
Warm waste pond \\
\end{tabular}}} & \multirow{2}{*}{$\begin{array}{c}\text { TRA-04/05 } \\
\\
\text { Warm waste retention } \\
\text { basin \& disposal well } \\
\end{array}$} & \multirow{3}{*}{\begin{tabular}{|c|} 
Brass Cap \\
$2.63 \mathrm{E} 01$
\end{tabular}} & \multirow{3}{*}{$\begin{array}{c}\begin{array}{c}\text { SLP } \\
\text { windblown }\end{array} \\
\\
2.10 \mathrm{E} 04\end{array}$} & \multirow{3}{*}{$\begin{array}{l}\text { Hot Tree } \\
9.29 \mathrm{E} 01\end{array}$} & \multicolumn{2}{|c|}{ Total Activity (Ci) } \\
\hline & & & & & & & & & & & & \multirow[t]{2}{*}{ Soils } & \multirow[t]{2}{*}{$\begin{array}{c}\text { Alluvium } \\
\text { perched } \\
\text { water }\end{array}$} \\
\hline $\begin{array}{l}\text { Surface } \\
\text { Area }\left(\mathrm{m}^{2}\right)\end{array}$ & $1.24 \mathrm{E} 04$ & $5.8 \mathrm{E} 01$ & $5.57 \mathrm{E} 00$ & $1.47 \mathrm{E} 04$ & $3.02 \mathrm{E} 03$ & $5.46 \mathrm{E} 03$ & $9.29 \mathrm{E} 03$ & $1.27 \mathrm{E} 04$ & & & & & \\
\hline Depth (m) & 0.035 & 11.7 & 0.305 & 0.152 & 1.83 & 3.75 & 0.457 & 0.15 & 3.05 & 0.101 & 3.66 & & \\
\hline $\mathrm{COPC}$ & \multicolumn{13}{|c|}{ Activity in Curies } \\
\hline $\mathrm{Ag}-108 \mathrm{~m}$ & $1.94 \mathrm{E}-03$ & & & & $1.25 \mathrm{E}-02$ & $3.12 \mathrm{E}-02$ & $8.22 \mathrm{E}-03$ & & & $1.24 \mathrm{E}-03$ & & $5.51 \mathrm{E}-02$ & \\
\hline Am-241 & & $1.91 \mathrm{E}-04$ & & & $1.65 \mathrm{E}-03$ & $5.74 \mathrm{E}+00$ & & & & $2.85 \mathrm{E}-03$ & & $5.74 \mathrm{E}+00$ & 2.95 \\
\hline $\mathrm{Cm}-244$ & & & & & & $5.02 \mathrm{E}-01$ & & & & & & $5.02 \mathrm{E}-01$ & \\
\hline Co-60 & $1.59 \mathrm{E}-03$ & $5.12 \mathrm{E}-02$ & $2.12 \mathrm{E}-05$ & $3.04 \mathrm{E}-03$ & $2.01 \mathrm{E}-01$ & $2.05 \mathrm{E}+00$ & $1.91 \mathrm{E}-01$ & $1.90 \mathrm{E}-02$ & $1.00 \mathrm{E}-03$ & $1.97 \mathrm{E}-02$ & $1.78 \mathrm{E}-04$ & $2.54 \mathrm{E}+00$ & 480 \\
\hline Cs-134 & & $3.20 \mathrm{E}-04$ & $8.94 \mathrm{E}-03$ & 7.74E-04 & $2.24 \mathrm{E}-03$ & $3.30 \mathrm{E}-03$ & $1.54 \mathrm{E}-02$ & & 4.00E-01 & & & 4.31E-01 & \\
\hline Cs-137 & $5.98 \mathrm{E}-03$ & $2.04 \mathrm{E}+00$ & 4.97E- 02 & $5.05 \mathrm{E}-02$ & $6.84 \mathrm{E}-01$ & $7.54 \mathrm{E}+01$ & $1.13 \mathrm{E}+00$ & $6.56 \mathrm{E}-03$ & $2.34 \mathrm{E}+00$ & $4.58 \mathrm{E}-02$ & 2.45E- 03 & $8.18 \mathrm{E}+01$ & \\
\hline Eu-152 & $8.14 \mathrm{E}-03$ & & & & $1.33 \mathrm{E}-02$ & $5.74 \mathrm{E}+00$ & $1.60 \mathrm{E}-02$ & & & & & $5.78 \mathrm{E}+00$ & \\
\hline Eu-154 & & $1.10 \mathrm{E}-03$ & & $2.02 \mathrm{E}-03$ & $7.00 \mathrm{E}-03$ & $1.44 \mathrm{E}+00$ & $6.60 \mathrm{E}-03$ & & & & & $1.46 \mathrm{E}+00$ & \\
\hline Eu-155 & & & & & & $8.26 \mathrm{E}-02$ & & & & & & $8.26 \mathrm{E}-02$ & \\
\hline $\mathrm{H}-3$ & & & & & & & & & & & & & 9,881 \\
\hline $\mathrm{Pu}-238$ & & $3.97 \mathrm{E}-05$ & & & & $5.74 \mathrm{E}-01$ & & & & & & $5.74 \mathrm{E}-01$ & \\
\hline $\mathrm{Pu}-239 / 240$ & & $4.78 \mathrm{E}-05$ & & & $2.57 \mathrm{E}-03$ & $6.10 \mathrm{E}+00$ & & & & & & $6.10 \mathrm{E}+00$ & \\
\hline Sr-90 & $6.83 \mathrm{E}-03$ & $1.87 \mathrm{E}+00$ & $2.12 \mathrm{E}-03$ & & $1.60 \mathrm{E}-02$ & $1.22 \mathrm{E}+02$ & & & $1.00 \mathrm{E}-01$ & $7.14 \mathrm{E}-03$ & $1.02 \mathrm{E}-03$ & $1.24 \mathrm{E}+02$ & 111 \\
\hline Th-228 & & & & & & $9.33 \mathrm{E}-03$ & & & & & & $9.33 \mathrm{E}-03$ & \\
\hline Th-230 & & & & & & $2.23 \mathrm{E}-02$ & & & & & & $2.23 \mathrm{E}-02$ & \\
\hline Th-232 & & & & & & $8.97 \mathrm{E}-03$ & & & & & & $8.97 \mathrm{E}-03$ & \\
\hline $\mathrm{U}-234$ & & & & & $1.28 \mathrm{E}-02$ & $9.33 \mathrm{E}-02$ & & $3.57 \mathrm{E}-03$ & & & & $1.10 \mathrm{E}-01$ & \\
\hline $\mathrm{U}-235$ & & & & & & $1.18 \mathrm{E}-03$ & & & & & & $1.18 \mathrm{E}-03$ & \\
\hline $\mathrm{U}-238$ & & & & & & $4.31 \mathrm{E}-02$ & & $4.19 \mathrm{E}-03$ & & & & 4.73E- 02 & \\
\hline $\begin{array}{r}\text { Soils inven } \\
\text { Short- } \\
\text { Total surfa }\end{array}$ & $\begin{array}{l}\text { ry was taker } \\
\text { ved inventor } \\
\text { area }\left(\mathrm{m}^{2}\right)=\end{array}$ & $\begin{array}{l}\text { from Table B } \\
\text { es not expecte } \\
\text { 8.14E04; total }\end{array}$ & $\begin{array}{l}-28 \mathrm{DOE} / \mathrm{I} \\
\mathrm{d} \text { to remair } \\
\text { volume }(\mathrm{m}\end{array}$ & $\begin{array}{l}-10531(\mathrm{D} \\
\text { in the aqu } \\
\text { 3) }=4.19 \mathrm{E}\end{array}$ & $\begin{array}{l}\text { OE-ID 19s } \\
\text { fer beyond } \\
-4 \text {; averag }\end{array}$ & $\begin{array}{l}\text { ). The larger inv } \\
0 \text { years are shov } \\
\text { epth of contamir }\end{array}$ & $\begin{array}{l}\text { entory by } \\
\text { on in pink } \\
\text { ation }(\mathrm{m})\end{array}$ & $\begin{array}{l}\text { ercent is represented } \\
\text { haded cells. } \\
5.20 \mathrm{E}-01\end{array}$ & grey-s & cells. & & & \\
\hline
\end{tabular}


The entire radiologic inventory of concern to the potential Site 5 RH-LLW disposal facility location resides above the first basalt contact in the alluvium either as contaminated water or as contaminated soils. The inventory shown in Table A-2 was carried through by the comprehensive RI/FS for the ATR Complex without further screening.

\section{A-2.3 Relevance to the Proposed Remote-Handled Low-Level A-2.4 Waste Disposal Facility Candidate Site 5}

Time periods beyond 100 years are of particular interest to the Candidate Site 5 for the onsite RH-LLW disposal facility alternative. This is consistent with cumulative impacts expected to occur following corrosion-induced waste container failure at the RH-LLW disposal facility. Container failure is not expected to occur within 300 years of facility closure, and contaminants in the aquifer prior to that period would be downgradient of Candidate Site 5 before radionuclides from the RH-LLW disposal facility could be transported through the vadose zone.

Highly sorbed radionuclides and short-lived radionuclides (i.e., H-3, Sr-90, Cs-127, and Co-60) were screened out in the NRF comprehensive RI/FS because they pose insignificant cumulative groundwater impacts for the 100-year scenario. However, the comprehensive RI/FS for the ATR Complex did not screen these constituents out. The following analyses of model adequacy for both areas will use the consistent inventory identified in the individual RI/FSs to determine whether or not they are of concern to the RH-LLW disposal facility.

\section{A-3. MODEL USED IN THE PREVIOUS GROUNDWATER IMPACTS ANALYSES}

Previous groundwater impacts analyses conducted in support of the comprehensive RI/FS for NRF and the ATR Complex are summarized in this section. The comprehensive risk analyses at NRF (WAG 8) and the ATR Complex (WAG 2) were both conducted using the model GWSCREEN (model theory documented in Rood 2003). Conceptually, the model is illustrated in Figure A-2. The fundamental process model assumes that contaminants released near land surface could be transported downward through the stratigraphic layers comprising the vadose zone and into the aquifer by infiltration from natural precipitation. Along this transport pathway, the dilute radionuclides can undergo advection, phasepartitioning, sorption, diffusion, dispersion, and radioactive chain decay and ingrowth. Once in the aquifer, similar transport and decay processes occur as contaminants move with the regional groundwater flow. The relative influences of these processes are, in part, determined by site-specific hydrogeochemistry and are, in part, contaminant specific. Advection, dispersion, and sorption are largely determined by the geostratigraphy and localized infiltration at each individual site. Transport and radioactive decay are contaminant specific and the contaminant inventory is dictated by the waste source.

In the modeling approach adopted for comprehensive risk assessments at NRF and the ATR Complex, the important parameters and characteristics are (1) representation of release from the source zone, (2) infiltration rate, (3) relative abundance of sorptive material in the vadose zone, and (4) velocity of water in the aquifer.

In Section A-4, the final comprehensive risk assessment model for NRF is reviewed. The review includes nuclide-specific parameters, vadose zone and aquifer parameters, and results predicted in the comprehensive RI/FS for NRF. In addition, a newer version of GWSCREEN (version 2.5s01-23-07) was used to confirm the interpretation of model parameters and implementation as presented in the final comprehensive risk assessment report (Westinghouse 1997). The reproduced results for NRF using the newer model are given in Section A-4.3. 


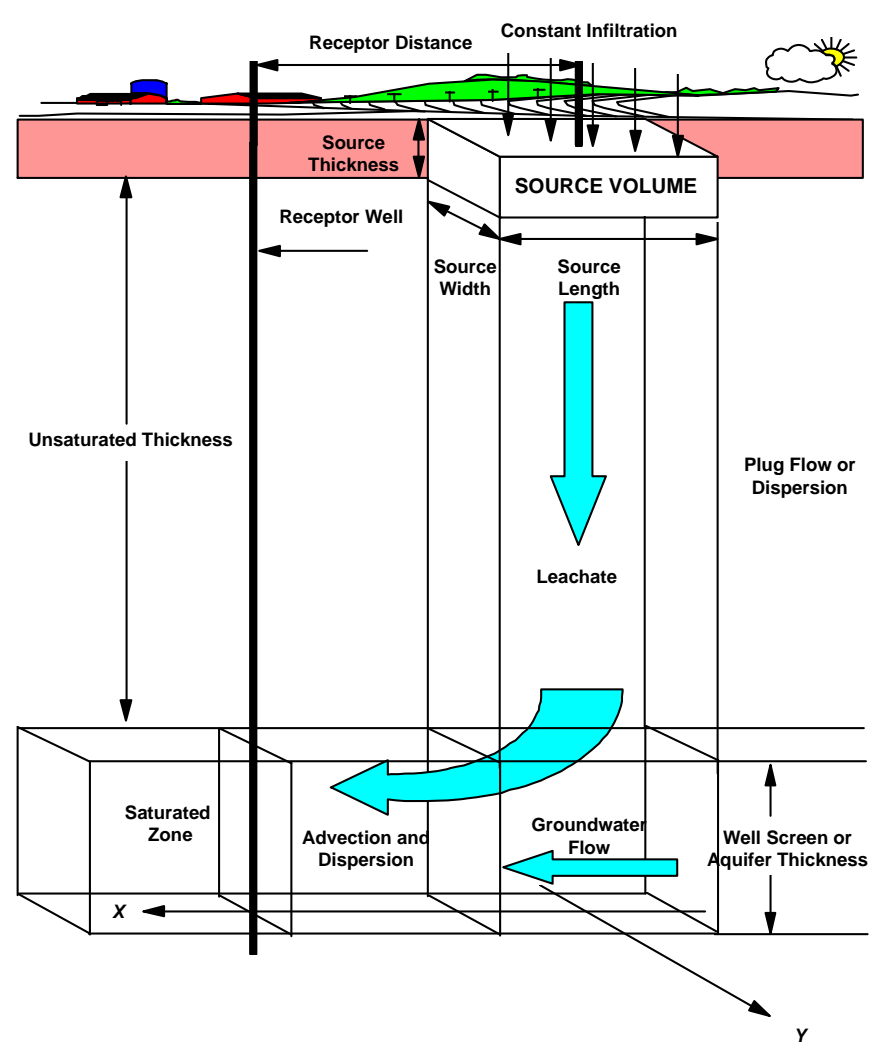

Figure A-2. Conceptual model of transport implemented for the Naval Reactors Facility.

Section A-5 contains the model parameters used in the ATR Complex assessment. The parameters applied in the comprehensive RI/FS for the ATR Complex (DOE-ID 1997b) were not used to re-evaluate or reproduce the ATR Complex groundwater impacts using the version 2.5s01-23-07 of GWSCREEN because the model is verified in Section A-4.3.

\section{A-4. SUMMARY OF THE FINAL COMPREHENSIVE RISK ASSESSMENT MODEL FOR THE NAVAL REACTORS FACILITY}

GWSCREEN was parameterized as discussed in the following sections using nuclide-specific parameters and model parameters describing the subsurface at NRF. The general conceptual model accounted for infiltration through the source region, desorption of radionuclides from the contaminated soils in the source region, downward transport and sorption in the vadose zone sediment, and dilution and dispersion in the aquifer. Sorption and transport through vadose zone basalt were conservatively excluded. 


\section{A-4.1 Nuclide-Specific Parameters}

Nuclide-specific parameters included source dimensions, activities at each source, and solubility limits. They also included sorption coefficients in the source region, vadose zone sediment and basalt, and aquifer basalt. Source dimensions and inventories are given in Table A-1 and other parameters applied in the NRF Comprehensive RI/FS are shown in Table A-3. Implications of the parameters chosen and the source of information used are discussed in the following subsections and in Section A-6.

Table A-3. Nuclide-specific parameters used in the Naval Reactors Facility comprehensive remedial investigation and feasibility study GWSCREEN analysis.

\begin{tabular}{|c|c|c|c|c|c|c|}
\hline \multirow[b]{2}{*}{ Radionuclide } & \multirow[b]{2}{*}{$\begin{array}{l}\text { Inventory } \\
\text { (Ci) }\end{array}$} & \multirow[b]{2}{*}{$\begin{array}{c}\text { Half-life } \\
\text { (years) }\end{array}$} & \multirow[b]{2}{*}{$\begin{array}{c}\text { Solubility Limit } \\
(\mathrm{mg} / \mathrm{L})\end{array}$} & \multicolumn{3}{|c|}{ Sorption Coefficients $\left(\mathrm{K}_{\mathrm{d}}\right)(\mathrm{mL} / \mathrm{g})$} \\
\hline & & & & $\begin{array}{l}\text { Source } \\
\text { zone }\end{array}$ & $\begin{array}{c}\text { Unsaturated } \\
\text { sediment }\end{array}$ & $\begin{array}{c}\text { Aquifer } \\
\text { basalt }\end{array}$ \\
\hline $\mathrm{C}-14$ & 1.32 & 5,730 & $1.0 \mathrm{E}+06$ & 1.2 & 1.2 & 1.2 \\
\hline $\mathrm{Np}-237$ & $6.67 \mathrm{E}-02$ & $2.14 \mathrm{E}+06$ & $1.50 \mathrm{E}-11$ & 22 & 22 & 22 \\
\hline U-234 & 2.77E-02 & $7.00 \mathrm{E}+08$ & $2.22 \mathrm{E}-06$ & 6 & 6 & 6 \\
\hline U-235 & $1.88 \mathrm{E}-03$ & $7.04 \mathrm{E}+08$ & 2.22E-06 & 6 & 6 & 6 \\
\hline $\mathrm{Pu}-239$ & $6.31 \mathrm{E}-02$ & $2.41 \mathrm{E}+04$ & 8.64E-02 & 22 & 22 & 22 \\
\hline $\mathrm{Pu}-244$ & $6.71 \mathrm{E}-04$ & $8.30 \mathrm{E}+07$ & 8.64E-02 & 22 & 22 & 22 \\
\hline
\end{tabular}

\section{A-4.1.1 Source Activity and Dimensions}

Source activity used in the NRF comprehensive RI/FS is given in Table A-1 for each radionuclide. Source dimensions for each radionuclide simulated varied as shown in Table A-1. The volume and geometry of the source zones were reflective of the general shape and volume of sites being modeled. The dimensions applied in GWSCREEN were large enough to contain the entire contaminated zone and the highest recorded soil contaminant concentration was preserved. This resulted in a modeled contaminant activity larger than actual based on the field sampling investigations and laboratory analyses.

Implemented in GWSCREEN, it was assumed that the length was oriented in a direction parallel to the groundwater flow direction, which provides a conservative downgradient concentration. Using the largerthan-actual source inventory also is conservative.

\section{A-4.1.2 Solubility Limits}

Solubility limits used in the NRF comprehensive RI/FS were calculated by Golder Associates for each radionuclide based on the $\mathrm{pH}, \mathrm{Eh}$, and CEC of the abandoned land fill areas (Westinghouse 1997). These values are provided in Table A-3, Column 4 for the radionuclides shown in Table A-1.

\section{A-4.1.3 Sorption Coefficients $\left(K_{d}\right)$}

Sorption coefficients applied to the source zone, unsaturated sediment, and aquifer are given in Table A-3. Column 5 contains the values used in the source zone, which were assumed to be contaminated soils. Column 6 contains the values applied in the unsaturated sediment (assumed to be sediment because the basalt was conservatively excluded), and the sorption coefficient applied for aquifer basalt is given in Column 7. Even though the media in each region is different, the values applied for each media were the same. For uranium and plutonium, the $\mathrm{K}_{\mathrm{d}}$ were assigned the default Track 2 values (DOEID 1994). The Track 2 values and process were designed to provide conservative estimates of transport for evaluating low hazard sites and for screening purposes. Neptunium was assumed to be transported (sorbed) similarly to plutonium, probably because a Track 2 value was not provided. The default Track 2 sorption coefficient for carbon is zero. $\mathrm{NRF}$ applied a value of $1.2 \mathrm{~mL} / \mathrm{g}$ which was the lowest $\mathrm{Kd}$ value 
in DOE-ID 1994 other than zero. The value applied is between the reference value for sand $(5 \mathrm{~mL} / \mathrm{g})$ and 0.01 values identified for other media.

\section{A-4.1.4 Daughter Products}

Chain decay was not accounted for in the comprehensive RI/FS for NRF.

\section{A-4.1.5 Risk and Dose Coefficients}

Risk values and peak concentrations were provided in the WAG 8 comprehensive RI/FS. Doses were not required to be provided under CERCLA, but are required under DOE Order 435.1. Doses are required because they provide a basis for determining cumulative effects (i.e., they are additive), whereas concentrations are not additive across multiple radionuclides. Under CERCLA, cumulative effects were based on cumulative risk.

\section{A-4.2 Other Model Parameters}

In addition to the radionuclide-specific parameters listed in the previous section, an infiltration rate and other model parameters are required for the source zone, vadose zone, and aquifer. For each of these regions, the model parameters used in the WAG 8 comprehensive RI/FS are shown in Table A-4. The origin of these parameters is discussed in the following subsections.

Table A-4. Non-nuclide specific parameters used in the Naval Reactors Facility comprehensive remedial investigation/feasibility study.

\begin{tabular}{|c|c|c|c|}
\hline Parameter & Value & Parameter & Value \\
\hline Infiltration rate (m/year) & 0.1 & \multicolumn{2}{|c|}{ Aquifer } \\
\hline \multicolumn{2}{|l|}{ Source } & $\begin{array}{l}\text { Well screen } \\
\text { thickness } \\
\text { (m) }\end{array}$ & 15 \\
\hline Bulk density $\left(\mathrm{g} / \mathrm{cm}^{3}\right)$ & 1.6 & $\begin{array}{l}\text { Bulk density } \\
\left(\mathrm{g} / \mathrm{cm}^{3}\right)\end{array}$ & 1.9 \\
\hline Moisture content & 0.3 & $\begin{array}{l}\text { Pore } \\
\text { velocity } \\
\text { (m/year) }\end{array}$ & 253 \\
\hline \multicolumn{2}{|c|}{ Unsaturated Zone } & Porosity & 0.1 \\
\hline Thickness (m) & 10.7 & $\begin{array}{l}\text { Longitudinal } \\
\text { dispersivity } \\
\text { (m) }\end{array}$ & $\begin{array}{l}10 \% \text { of } \\
\text { transport } \\
\text { distance }^{\mathrm{a}}\end{array}$ \\
\hline Bulk density $(\mathrm{g} / \mathrm{cm} 3)$ & 1.9 & $\begin{array}{l}\text { Transverse } \\
\text { dispersivity } \\
\text { (m) }\end{array}$ & $\begin{array}{l}10 \% \text { of } \\
\text { longitudinal } \\
\text { dispersivity }\end{array}$ \\
\hline Moisture content & 0.07 & $\begin{array}{l}\text { Aquifer } \\
\text { thickness } \\
\text { (m) }\end{array}$ & 76 \\
\hline
\end{tabular}




\section{A-4.2.1 Infiltration Rate}

All simulations of transport at NRF were provided for infiltration rates of $0.1 \mathrm{~m} / \mathrm{year}$, representing dry conditions and $1 \mathrm{~m} /$ year to represent flood conditions. The $0.1 \mathrm{~m} /$ year infiltration rate is roughly one-half of the average annual precipitation occurring at NRF. This does not take evapotranspiration into account at NRF and provides a very conservative infiltration value. The value of $1 \mathrm{~m} /$ year is roughly four times the annual average precipitation at NRF (and INL) and would only occur if the source region were subject to extreme flooding or if the Big Lost River were to overflow onto the contaminated sites, which is a highly unlikely occurrence given that NRF is over 1 mile from the Big Lost River.

Several of the sites at NRF either contain anthropogenic water or have been historically wet, including the sewage lagoon and the industrial waste ditch. Over the thousands of years that would be required for radionuclides of concern to be leached from the alluvial sediment, it is likely that geologic depositional processes would fill the depressions, reducing ponding and compacting the sediment of the source region. It is also unlikely that anthropogenic sources of water would continue well into the future. These factors were not taken into account in the conservative selection of $0.1 \mathrm{~m} /$ year applied throughout the entire simulation period.

\section{A-4.2.2 Source Zone Parameters}

Parameterization of the source zone requires sorption coefficients (Table A-3), bulk density, and moisture content to determine the total sorption occurring in the source region and to determine the transport velocity. The bulk density used for the source region was set to $1.6 \mathrm{~g} / \mathrm{cm}^{3}$. It was estimated from analyses of alluvium samples collected in 1987 as part of the Envirodyne hydrogeological investigation of the industrial waste ditch (Envirodyne 1988) and confirmed by samples collected during the 1993 hydrogeological investigation of the industrial waste ditch (WEC 1994). The moisture content was assumed to be 0.3 , corresponding to the default Track 2 value (DOE-ID 1994).

\section{A-4.2.3 Unsaturated Zone Parameters}

The bulk density used in the model simulations for the vadose zone was assumed to be $1.9 \mathrm{~g} / \mathrm{cm}^{3}$. This corresponds to the Track 2 default value for basalt (page C-9 of DOE-ID 1994), and is higher than the sediment value used in the source zone. The moisture content applied in the unsaturated zone corresponds to the Track 2 value as well, but this value is representative of the basalt region. Moisture contents in the sediment would be expected to be much higher.

At NRF, the total alluvium thickness is on the order of $40 \mathrm{ft}(12.2 \mathrm{~m})$. Beneath the alluvium, there are additional sedimentary interbeds between the basalt flows. In the comprehensive NRF RI/FS model, it was assumed that the total unsaturated zone thickness was only $10.68 \mathrm{~m}$, including the entire source zone, alluvium, and interbeds below the source zone. In the INL subsurface, the majority of sorption occurs in the alluvium and sedimentary interbeds. By accounting for only a portion of the sedimentary material, the total sorption capacity factored into the model was very conservative.

\section{A-4.2.4 Aquifer Parameters}

Aquifer parameters include bulk density, Darcy velocity (or pore velocity), porosity, longitudinal dispersivity, transverse dispersivity, aquifer thickness, and well screen thickness:

- $\quad$ Bulk density was applied a value representative of basalt. This is appropriate because horizontal flow in the aquifer occurs primarily through basalt and not sediment; a bulk density of $1.9 \mathrm{~g} / \mathrm{cc}$ was applied. 
- Pore water velocity was determined from groundwater monitoring well data that provided an estimate of aquifer transmissivity (347 m/day), measured hydraulic gradient (0.0002), an assumed aquifer thickness of $250 \mathrm{ft}$, and the Track 2 default porosity of 0.1 . The value assigned to the aquifer pore water velocity was $253 \mathrm{~m} /$ year, corresponding to a Darcy velocity of $25.3 \mathrm{~m} / \mathrm{year}$.

- Based on studies showing that dispersivity is scale dependent and guidance from the Environmental Protection Agency (Gelhar 1986), a longitudinal dispersivity of $10 \%$ of the simulation area, and transverse dispersivity of $10 \%$ of the longitudinal dispersivity was used.

\section{A-4.3 Reproducing the Naval Reactors Facility Predicted Cumulative Results}

GWSCREEN version 2.5s01-23-07 was used to compute peak concentrations and arrival times for each radionuclide shown in Table A-1 using the parameters reviewed in Sections A-4.1 and A-4.2. These results are shown in Table A-5, Columns 2 and 3. The results reported in the comprehensive NRF RI/FS are shown in Table A-5, Columns 4 and 5 (from Table 18-16 of Westinghouse 1997) that were computed using GWSCREEN version 2.02. The comparison between the 1997 results and those obtained using the newer version indicates that the results can be reproduced using the current version of GWSCREEN.

Table A-5. GWSCREEN results for the Naval Reactors Facility given in Westinghouse (1997) and reproduced using GWSCREEN version 2.5 (01-23-07).

\begin{tabular}{|c|c|c|c|c|}
\hline \multirow[b]{2}{*}{ Radionuclide } & \multicolumn{2}{|c|}{$\begin{array}{l}\text { Values shown in Table } 18-16 \text { of Westinghouse } \\
\text { (1997) using GWSCREEN Version } 2.02\end{array}$} & \multicolumn{2}{|c|}{$\begin{array}{l}\text { Values produced using GWSCREEN } \\
\text { Version } 2.5 \mathrm{~s} 01-23-07\end{array}$} \\
\hline & $\begin{array}{l}\text { Peak Concentration }{ }^{\mathrm{a}} \\
(\mathrm{pCi} / \mathrm{L})\end{array}$ & $\begin{array}{l}\text { Years to Occurrence } \\
\text { of Peak }\end{array}$ & $\begin{array}{l}\text { Peak Concentration }{ }^{\mathrm{a}} \\
(\mathrm{pCi} / \mathrm{L})\end{array}$ & $\begin{array}{l}\text { Years to Occurrence } \\
\text { of Peak }\end{array}$ \\
\hline C-14 & 221.0 & 271 & 229.1 & 229 \\
\hline Np-237 & 0.649 & 5,274 & 0.648 & 5,283 \\
\hline $\mathrm{Pu}-239$ & 0.591 & 4,822 & 0.591 & 4,829 \\
\hline $\mathrm{Pu}-244$ & 0.0316 & 4,812 & 0.0316 & 4,821 \\
\hline U-234 & 3.17 & 1,416 & 3.16 & 1,418 \\
\hline U-235 & 0.334 & 1,268 & 0.334 & 1,270 \\
\hline
\end{tabular}

\section{A-5. SUMMARY OF THE FINAL COMPREHENSIVE RISK ASSESSMENT MODEL FOR THE ADVANCED TEST REACTOR COMPLEX}

The comprehensive RI/FS for the ATR Complex (TRA) was conducted under OU 2-13

(DOE-ID 1997b). This investigation included a baseline risk assessment to incorporate sites identified in a Screening and Gap Analysis Report (Attachment IX of the OU 2-13 Work Plan; INEL 1995) with predicted risk greater than $1 \times 10^{-6}$ for a current occupational worker and for a 30-year future residential scenario. The purpose of a baseline risk assessment is to assess unmitigated risks to human health and the environment to determine whether the risks are acceptable without corrective action. The retained sites containing unmitigated radionuclides are listed in Table A-2. In the analysis of future cumulative groundwater ingestion risk from all unmitigated sites, the sources of contaminants were considered to originate in perched water, to be injected into the aquifer by the TRA-05 disposal well, or to be contamination that could leach from surface and near surface soils. The groundwater concentrations 
estimated to be produced by each of the three sources were used together to produce a total predicted groundwater concentration for each radionuclide.

Concentrations were predicted as a result of perched water migration and injected sources under OU 2-12 (Dames and Moore 1992) using a two-dimensional flow and transport model calibrated to perched water levels and contaminant concentrations. The predicted concentrations, substantiated by subsequent monitoring were used as the basis for those incorporated into the OU 2-13 comprehensive RI/FS (DOE-ID 1997b). The OU 2-12 model was initially run for a period of 125 years, which means predicted concentrations for the 1,000-year time period were unavailable. As a result, concentrations predicted to occur as a result of the perched water and injection sources out to 30 years and 100 years were used to evaluate the residential exposure scenarios. Model results were not extended beyond 100 years under OU 2-13 because it was predicted that the perched water sources would dry up within several decades of facility closure. he greater than 1,000 year arrival of nuclides was not included in the overall analysis because it was not required under CERCLA. Concentrations predicted with the OU 2-12 perched water model included Am-241, Co-60, H-3, and Sr-90.

Direct injection of H-3 was modeled separately as part of the OU 3-13 RI/FS (DOE-ID 1997a). This evaluation was performed using the three-dimensional TETRAD model developed to evaluate the fate of contaminants originating at INTEC. The OU 3-13 model included H-3 at the ATR Complex because of potential overlap with the H-3 originating at INTEC in the vicinity of INTEC. The OU 3-13 RI/FS model showed that the H-3 injected at the ATR Complex migrated in a path just west of the plume originating at INTEC, and that the $8.92 \mathrm{E}+03 \mathrm{Ci}$ of $\mathrm{H}-3$ originating at the ATR Complex would fall below the MCL within 100 years. This was confirmed by the OU 10-08 modeling, which evaluated the potential for plumes from the ATR Complex and INTEC to comingle (DOE-ID 2008).

The remaining contaminated soil sources were evaluated explicitly using GWSCREEN under OU 2-13. The source inventories associated with contaminated soils (shown in Table A-2) are principally associated with soils in the warm waste ponds at the ATR Complex. Because the principal source was reduced to contaminated soils, the model used to evaluate the comprehensive risk at the ATR Complex was very similar to that used in the NRF analysis discussed in Section A-4. Groundwater concentrations resulting from contaminated soils at the ATR Complex were estimated under OU 2-13 using GWSCREEN for time periods out to 10,000 years (DOE-ID 1997b). Model parameters used in the ATR Complex evaluation are discussed in the following subsections.

To evaluate the overall unmitigated hypothetical future groundwater ingestion risk, predicted concentrations from all three models were used. Peak concentrations for direct-injected H-3 occurred prior to arrival of $\mathrm{H}-3$ from the perched water. Peak concentrations for radionuclides pre-existing in the perched water occurred earlier in time than for those originating in contaminated soils near land surface. The time offset allowed the peak risk or dose to be evaluated using results of the OU 2-12, OU 3-13, or OU 2-13 models. As a result, the soil sources were used as the basis for the groundwater ingestion risk calculations for time periods greater than 125 years.

\section{A-5.1 Nuclide-Specific Parameters}

Nuclide specific parameters include the source dimensions, activities at each source, solubility limits, and sorption coefficients in the source region, vadose zone sediment and basalt, and aquifer basalt. Values used in the OU 2-13 comprehensive RI/FS for the ATR Complex are discussed in the following subsections and are shown in Table A-6. Implications of the parameter choices are discussed in Section A-6. 


\section{A-5.1.1 Source Activity and Dimensions}

The total mass of each contaminant shown in Table A-2 was calculated by summing the contaminant masses from retained source sites. In the OU 2-13 comprehensive RI/FS, the contaminant mass at each retained source site was estimated by multiplying the mass of contaminated soil at each site by the $95 \%$ upper confidence limit (UCL) concentration (on the mean), or the maximum concentration if the $95 \%$ UCL was higher than the maximum (i.e., too few sample points). This inventory provides a conservative source estimate.

The length of source parallel to flow, width of source perpendicular to flow, and thickness of the sources were based on the site dimensions for each contaminated soil site given in Table B-19 of DOE-ID (1997b). These dimensions included a surface area and depth. The length and width values were calculated by taking the square root of the total retained site surface area (footnote of Table A-2). The thickness used in evaluation of comprehensive risk was the average depth of contamination.

\section{A-5.1.2 Solubility Limits}

Solubility limits used are provided in Table A-6, Column 8 for each radionuclide.

\section{A-5.1.3 Sorption Coefficients $\left(K_{d}\right)$}

Sorption coefficients in the source zone, unsaturated sediment, and aquifer used in the GWSCREEN calculations are given Table A- 6 . Column 8 contains the values used in the source zone, which was assumed to be contaminated soils. Column 9 contains the values applied in the unsaturated sediment and the sorption coefficient applied for aquifer basalt is given in Column 10. These values represent INL Track $2 K_{d} s$ with the exception of curium, plutonium, and europium. The $K_{d} s$ for curium, plutonium, europium and thorium are consistent with more realistic $\mathrm{K}_{d} \mathrm{~S}$ used for OU 3-14 at INTEC, which were based on an extensive evaluation of literature (Appendix D, DOE-ID 2006a).

\section{A-5.1.4 Daughter Products}

Chain decay was accounted for using the daughter half-lives shown in Table A-6, Columns 3 through 6. The chain decay progeny shown in Table A-6 appears to have incorrectly included progeny with very short half-lives (less than 1 year) that would be in secular equilibrium with the parent and excluded progeny with longer half-lives where secular equilibrium could not be assumed. This has the potential to influence the predicted concentrations of $\mathrm{Am}-241$ and $\mathrm{Pu}-238$ because most of the impacts from these radionuclides come from their longer-lived daughters ( $\mathrm{Np}-237$ and U-234, respectively) and not from the parent. The dose and risk contribution for progeny depends not only on their respective concentrations, but also depends on the parent nuclide residence time in the vadose zone. Faster transport resulting from higher infiltration rates reduces the ingrowth of progeny, while slower infiltration allows more ingrowth to occur. As shown in Section A-7, the combination of infiltration rate and progeny included in the original OU 2-13 baseline risk assessment would not have resulted in an unacceptable concentration, dose, or risk. 
Table A-6. Nuclide-specific parameters used in the Operable Unit 2-13 comprehensive remedial investigation and feasibility study for the Advanced Test Reactor Complex (GWSCREEN parameters for contaminated soil sites).

\begin{tabular}{|c|c|c|c|c|c|c|c|c|c|}
\hline \multirow[b]{2}{*}{ Radionuclide } & \multicolumn{5}{|c|}{ Half-life (years) } & \multirow[b]{2}{*}{$\begin{array}{l}\text { Solubility Limit } \\
(\mathrm{mg} / \mathrm{L})\end{array}$} & \multicolumn{3}{|c|}{ Distribution Coefficients $\left(\mathrm{K}_{\mathrm{d}}\right)(\mathrm{mL} / \mathrm{g})$} \\
\hline & Parent & $\begin{array}{c}\text { 1st } \\
\text { Daughter }\end{array}$ & $\begin{array}{c}\text { 2nd } \\
\text { Daughter }\end{array}$ & $\begin{array}{c}\text { 3rd } \\
\text { Daughter }\end{array}$ & $\begin{array}{c}\text { 4th } \\
\text { Daughter }\end{array}$ & & Source & Unsaturated Zone & Aquifer \\
\hline Ag- $108 \mathrm{~m}$ & 127 & & & & & 2,310 & 90 & 90 & 9 \\
\hline Am-241 & 432 & $2.14 \mathrm{E}+06$ & 7.39E-02 & $1.59 \mathrm{E}+05$ & 7,340 & $2.01 \mathrm{E}-10$ & 340 & 340 & 34 \\
\hline $\mathrm{Cm}-244$ & 18.1 & 6,570 & $2.34 \mathrm{E}+07$ & $1.41 \mathrm{E}+10$ & 5.75 & $2.22 \mathrm{E}-06$ & 2,000 & 2,000 & 200 \\
\hline Co-60 & 5.27 & & & & & 23.5 & 10 & 10 & 1 \\
\hline Cs-134 & 2.06 & & & & & $6.65 \mathrm{E}+04$ & 500 & 500 & 50 \\
\hline Cs-137 & 30.2 & $4.85 \mathrm{E}-06$ & & & & $6.65 \mathrm{E}+04$ & 500 & 500 & 50 \\
\hline Eu-152 & 13.6 & $1.10 \mathrm{E}+14$ & & & & 50.3 & 650 & & 65 \\
\hline Eu-154 & 8.8 & & & & & 50.3 & 650 & 650 & 65 \\
\hline Eu-155 & 4.71 & & & & & 50.3 & 650 & 650 & 65 \\
\hline \multicolumn{10}{|l|}{$\mathrm{H}-3$} \\
\hline $\mathrm{Pu}-238$ & 87.8 & $2.45 \mathrm{E}+05$ & 77,000 & 1,600 & 0.0105 & $3.25 \mathrm{E}-07$ & 1,500 & 1,500 & 150 \\
\hline $\mathrm{Pu}-239 / 240$ & 24,100 & $7.04 \mathrm{E}+08$ & 0.00291 & 32,800 & 21.8 & $3.25 \mathrm{E}-07$ & 1,500 & 1,500 & 150 \\
\hline Sr-90 & 28.6 & 0.00731 & & & & $4.38 \mathrm{E}+04$ & 24 & 24 & 2.4 \\
\hline Th-228 & 1.91 & & & & & $1.00 \mathrm{E}+06$ & 100 & 100 & 10 \\
\hline Th-230 & 75400 & 1,600 & 0.0105 & $5.80 \mathrm{E}-06$ & $5.10 \mathrm{E}-05$ & $1.00 \mathrm{E}+06$ & 100 & 100 & 10 \\
\hline Th-232 & $1.41 \mathrm{E}+10$ & 5.75 & & & & $1.00 \mathrm{E}+06$ & 100 & 100 & 10 \\
\hline $\mathrm{U}-234$ & $2.45 \mathrm{E}+05$ & 77,000 & 1,600 & 0.0105 & $5.80 \mathrm{E}-06$ & $2.22 \mathrm{E}-06$ & 6 & 6 & 0.6 \\
\hline $\mathrm{U}-235$ & $7.04 \mathrm{E}+08$ & 0.00291 & 32,800 & 21.8 & 4.14E- 05 & $2.22 \mathrm{E}-06$ & 6 & 6 & 0.6 \\
\hline U-238 & $4.47 \mathrm{E}+09$ & 0.066 & $2.22 \mathrm{E}-06$ & 7.64E-04 & $2.45 \mathrm{E}+05$ & $2.22 \mathrm{E}-06$ & 6 & 6 & 0.6 \\
\hline
\end{tabular}




\section{A-5.2 Other Model Parameters}

Parameters required for the vadose zone and aquifer include the surface infiltration rate, thickness of different media in each zone, bulk density (used to determine total sorption and retardation), moisture content, well-screen thickness, pore water velocity or Darcy velocity, and porosity. Table A-7 contains the parameters used in the ATR Complex comprehensive RI/FS by region. The source of the parameters used is discussed in the following subsections. Implications of the parameter choices are discussed in Section A-6.

Table A-7. Non-nuclide-specific parameters used in the Advanced Test Reactor Complex comprehensive remedial investigation.

\begin{tabular}{|c|c|c|c|}
\hline Parameter & Value & Parameter & Value \\
\hline Infiltration rate ( $\mathrm{m} /$ year) & $0.1^{*}$ & \multicolumn{2}{|c|}{ Aquifer } \\
\hline \multicolumn{2}{|c|}{ Source } & Well screen thick (m) & $15^{*}$ \\
\hline Source length $(\mathrm{m})$ & 286 & Bulk density $\left(\mathrm{g} / \mathrm{cm}^{3}\right)$ & $1.9^{*}$ \\
\hline Source width (m) & 286 & Porosity & $0.1^{*}$ \\
\hline Source thickness (m) & 0.515 & Pore velocity (m/year) & $570^{*}$ \\
\hline Bulk density $\left(\mathrm{g} / \mathrm{cm}^{3}\right)$ & $1.5^{*}$ & Longitudinal dispersivity (m) & $9 *$ \\
\hline Moisture content & $0.3^{*}$ & Transverse dispersivity $(\mathrm{m})$ & 4* \\
\hline \multicolumn{2}{|c|}{ Unsaturated Zone } & Receptor distance $(\mathrm{m})$ & 143 \\
\hline Thickness (m) & 14.2 & \multirow{3}{*}{\multicolumn{2}{|c|}{ *Track 2 default parameters (DOE-ID 1994). }} \\
\hline Bulk density $\left(\mathrm{g} / \mathrm{cm}^{3}\right)$ & $1.9^{*}$ & & \\
\hline Moisture content & $0.3^{*}$ & & \\
\hline
\end{tabular}

\section{A-5.2.1 Infiltration Rate}

All simulations of transport at the ATR Complex used infiltration rates of $0.1 \mathrm{~m} /$ year. The $0.1-\mathrm{m} / \mathrm{year}$ infiltration rate is roughly one-half of the average annual precipitation occurring across INL. This essentially excludes evapotranspiration and provides a very conservative infiltration value. A flooding scenario was not considered at the ATR Complex because it is unlikely that flows in the Big Lost River would reach the ATR Complex because of distance from the river. The long-term simulations conducted in support of the ATR Complex comprehensive RI/FS assumed water discharges to the warm waste pond would cease, but that infiltration would not return to background conditions (i.e., lower infiltration) over the period of thousands of years. The conservative value of $0.1 \mathrm{~m} /$ year is discussed in Section A-6.

\section{A-5.2.2 Source Zone Parameters}

In addition to source dimensions, radionuclide inventory and sorption coefficients shown in Tables A-2 and A-6, parameterization of the source zone requires the bulk density and moisture content to determine the total sorption occurring in the source region and the transport velocity. The bulk density used for the source region was set to $1.5 \mathrm{~g} / \mathrm{cm}^{3}$. It is approximately equal to the value derived from analyses of alluvium samples collected at NRF and that represent sediment in general across the INL.

Similarly, the moisture content was assumed to be 0.3 , which also is representative of an average soil under 0.1-m/year infiltration conditions as recommended in Track 2 guidance (DOE-ID 1994). 


\section{A-5.2.3 Unsaturated Zone Parameters}

The bulk density value used in the model simulations for the vadose zone was assumed to be $1.9 \mathrm{~g} / \mathrm{cm}^{3}$. This corresponds to the Track 2 default value for basalt (page C-11 of DOE-ID 1994) and is higher than the sediment value used in the Track 2 source zone. The moisture content applied in the unsaturated zone corresponds to the Track 2 value for sediment, which is consistent with sorption occurring to sediment rather than basalt. Therefore, selection of moisture content and bulk density are inconsistent.

At the ATR Complex, the total alluvium thickness is on the order of 15 to $18 \mathrm{~m}$. Cumulative sediment thickness under the ATR Complex based on a geostatistical analysis (INL 2010a) is on the order of $20 \mathrm{~m}$. In the OU 2-13 model, it was assumed that the total unsaturated zone thickness was $14.2 \mathrm{~m}$, which accounts for part of the alluvium and none of the underlying sedimentary interbeds below the source zone. This conservatism is much larger than the lack of conservatism introduced through the high bulk density.

\section{A-5.2.4 Aquifer Parameters}

Aquifer parameters include bulk density, Darcy velocity (or pore velocity), porosity, longitudinal dispersivity, transverse dispersivity, aquifer thickness, and well screen thickness:

- $\quad$ Bulk density was applied a value representative of basalt. This is appropriate because horizontal flow in the aquifer occurs primarily through basalt and not sediment; a bulk density of $1.9 \mathrm{~g} / \mathrm{cc}$ was applied.

- Pore water velocity was assigned a value of $570 \mathrm{~m} /$ year, with a corresponding porosity of 0.1 . This is the Track 2 default value (DOE-ID 1994). The corresponding Darcy velocity is $57 \mathrm{~m} /$ year, about twice the aquifer Darcy velocity assumed at NRF and three-times the value determined by the WAG 10 aquifer model (DOE-ID 2008; Wood et al. 2007)

- $\quad$ The default Track 2 vertical mixing thickness (i.e., well screen thickness) in GWSCREEN is $15 \mathrm{~m}$. This thickness represents the length of a typical well screen in the upper aquifer. For Track 2 computations, it is assumed this is the aquifer thickness. With the receptor on the downgradient edge of the source, the amount of vertical mixing is minimal, and therefore, this assumption is both conservative and reasonable.

- Dispersivity in the longitudinal direction was assigned a value of $9 \mathrm{~m}$, and a value of $4 \mathrm{~m}$ in the transverse direction. These are the Track 2 default values (DOE-ID 1994). The source dimension was $286 \mathrm{~m}$, and the downgradient receptor distance was $143 \mathrm{~m}$. In the NRF comprehensive RI/FS, the longitudinal dispersivity was assigned a value of $10 \%$ of the source length, with a transverse dispersivity equal to $1 \%$ of the source length.

\section{A-6. CURRENT UNDERSTANDING AND RECOMMENDED MODEL PARAMETERS}

In the time period between preparation of the comprehensive RI/FSs for NRF and the ATR Complex, several field-scale studies and CERCLA evaluations at INL have been conducted. Of key note are the large-scale infiltration test (Magnuson 1995), the RI/FS for OU 3-13 (DOE-ID 1997a), and the RI/FSs for OU 3-14 (DOE-ID 2006a), OU 7-13/14 (DOE-ID 2006b), and OU 10-08 (DOE-ID 2008). Each of these studies has increased the base of information used to assign infiltration rates to disturbed and undisturbed soils, increased our understanding of the sedimentary structure across INL and its general importance to water, contaminant movement, and sorption in the unsaturated zone; it also has added to our confidence in sorption processes and parameters. Additionally, since preparation of the NRF and ATR Complex comprehensive RI/FSs, dose coefficients used to determine dose from groundwater concentrations have 
been updated at the national level by EPA. Relevant parameters for each of these are discussed in the following subsections. Predictive results using currently accepted model parameters are presented in Section A-7.

\section{A-6.1 Infiltration Rates}

An infiltration rate of $10 \mathrm{~cm} /$ year is the default Track 2 value (DOE-ID 1994) used for source leaching and the unsaturated transport portion of groundwater screening assessments for low-hazard INL CERCLA sites. To put this into perspective, the total precipitation at INL is on the order of $20 \mathrm{~cm} /$ year, and an average of $1 \mathrm{~cm} /$ year is accepted for undisturbed soil conditions.

To put the $10 \mathrm{~cm} /$ year Track 2 value into perspective, background infiltration rates outside the Subsurface Disposal Area at RWMC in undisturbed sediment have been estimated to be on the order of $1.0 \mathrm{~cm} /$ year (Cecil et al. 1992) or as low as $0.1 \mathrm{~cm} /$ year based on Mattson et al. (2004). Site-specific estimates under disturbed conditions inside facilities have been determined using inverse modeling of meteorological time histories and measured soil moisture profiles obtained with neutron logging for monitoring locations around the Subsurface Disposal Area (Martian and Magnuson 1994; Martian 1995). These inverse modeling estimates were used in combination with surface topography to assign a distribution of three infiltration rates across the Subsurface Disposal Area (Martian 1995). The three rates applied are $1 \mathrm{~cm} /$ year ( $0.4 \mathrm{in}$./year), which is the same as the background infiltration rate traditionally assumed for undisturbed soil outside the Subsurface Disposal Area; $3.7 \mathrm{~cm} /$ year (1.5 in./year), representing a medium value; and $10.0 \mathrm{~cm} /$ year (4 in./year), representing infiltration obtained near drainage ditches where water and snow are intentionally diverted (DOE-ID 2006b). For a more direct comparison to the single-rate infiltration values assigned in the NRF and ATR Complex evaluation, the spatial average inside the Subsurface Disposal Area of the spatially varying rates (although the spatial average was never explicitly used for the RWMC remedial investigation and baseline risk assessment) was $5 \mathrm{~cm} /$ year.

Similarly, inverse modeling at INTEC was performed for the OU 3-14 tank farm soil and groundwater RI/FS (DOE-ID 2006a) to determine infiltration rates. This study indicated net infiltration across disturbed INTEC soils was $18 \mathrm{~cm} /$ year. This value is representative of highly disturbed gravels in the tank farm where infiltration is enhanced by leaks through a temporary cover and evapotranspiration is eliminated by the cover. As with the Subsurface Disposal Area model, disturbed conditions were accounted for explicitly. In the INTEC model, infiltration through undisturbed areas at INTEC was assigned a value of $1 \mathrm{~cm} /$ year and disturbed areas were assigned the higher rate of $18 \mathrm{~cm} /$ year (DOE-ID 2006a).

For moderate to highly sorbing radionuclides of interest to the RH-LLW disposal facility, the vadose zone transit time will be on the order of 10,000 s to 100,000 s of years. Over these long time periods, natural compaction and weathering processes would return the contaminated soil source zones to undisturbed conditions at either NRF or the ATR Complex. Therefore, assuming 10-cm/year infiltration representative of disturbed conditions throughout the lifetime of the facility is very conservative and a value of $1 \mathrm{~cm} /$ year is probably more representative.

\section{A-6.2 Relative Sediment Abundance}

Geostratigraphy at INL is comprised of interlayered basalt and sedimentary interbeds. The basalt very readily transmits water vertically and has little adsorptive capacity. In contrast, sediment in the interbeds retains water and serves to retard downward migration of radionuclides. Sediment at both proposed sites contain a mixture of clays, silts, and sands, all of which hold sorptive capacity.

Primary sedimentary interbeds have been identified and extensively characterized through activities supporting CERCLA actions at the ATR Complex and near NRF, based on basalt age dating by Helm-Clark et al. (2005). The lateral continuity and variability in sediment was evaluated near the ATR 
Complex (INL 2010a), and it has been evaluated in support of this assessment using wells NRF-1, NRF-2, NRF-3, NRF-4, NRF-S5G, and MON-A-008 in the area containing NRF. Based on these evaluations, the mean cumulative sediment thickness for near the ATR Complex is approximately $20 \mathrm{~m}$, with an average alluvium thickness of $14.7 \mathrm{~m}$. At NRF, the alluvium thickness averages $10.3 \mathrm{~m}$, and the sediment thickness averages $9 \mathrm{~m}$.

\section{A-6.3 Sedimentary Interbed Properties}

Sediment texture and hydraulic conductivity also have been characterized as part of the ATR Complex CERCLA investigations (DOE-ID 1997b). Sediment comprising the interbeds near the ATR Complex contains mostly clay, silt, and sand with very little gravel. Percentages of clay, silt, sand, and gravel are 22.9, 38.6, 37.7, and 0.8\%, respectively (Doornbos et al. 1991). Sediment characteristics were catalogued at NRF during drilling operations for NRF-6 and NRF-7. Based on well logs for those wells, the sedimentary interbeds appear to be mostly silty sands with little gravel.

Hydraulic constitutive relationships have been documented for high-permeability sediment in DOE-ID (2006a) for the interbeds underlying INTEC. These relationships dictate the moisture content under various infiltration conditions. The high-permeability moisture characteristics result in a moisture content of 0.0979 at $10 \mathrm{~cm} /$ year infiltration. Lower moisture content results in higher retardation (net sorption), but also results in higher pore velocity.

\section{A-6.4 Sorption Parameters}

$\mathrm{K}_{\mathrm{d}} \mathrm{S}$ recommended by the Track 2 guidance (DOE-ID 1994), recommended for use by Jenkins (2001), or accepted for use by the State of Idaho and used in the OU 3-13 and OU 3-14 RI/FS are given in Table A-8. This table contains nuclides of interest to the proposed RH-LLW disposal facility, the ATR Complex, and NRF.

Table A-8. Distribution coefficients recommended by DOE-ID (1994), Jenkins (2001) and the State of Idaho and currently in use as screening values.

\begin{tabular}{|c|c|c|c|c|c|}
\hline Radionuclide & $\begin{array}{c}\mathrm{Kd} \\
(\mathrm{mL} / \mathrm{g})\end{array}$ & $\mathrm{K}_{\mathrm{d}}$ Reference & Radionuclide & $\begin{array}{c}\mathrm{K}_{\mathrm{d}} \\
(\mathrm{mL} / \mathrm{g})\end{array}$ & $K_{d}$ Reference \\
\hline Ac-227 & 450 & Jenkins (2001) & $\mathrm{Ni}-59$ & 100 & DOE-ID (1994) \\
\hline $\mathrm{Ag}-108 \mathrm{~m}$ & 90 & DOE-ID (1994) & $\mathrm{Ni}-63$ & 100 & DOE-ID (1994) \\
\hline Am-241d & 2 & DOE-ID (2006a) & $\mathrm{Np}-237$ & 2 & DOE-ID (2006a) \\
\hline Am- $242 m$ & 340 & DOE-ID (1994) & $\mathrm{Pa}-231$ & 550 & Jenkins (2001) \\
\hline $\mathrm{Am}-243$ & 340 & DOE-ID (1994) & Pm-147 & 240 & Jenkins (2001) \\
\hline Ba-133 & 50 & DOE-ID (1994) & $\mathrm{Pu}-238 \mathrm{e}$ & 1.6 & DOE-ID (2006a) \\
\hline $\mathrm{C}-14$ & 0 & DOE-ID (1994) & $\mathrm{Pu}-239$ & 22 & Jenkins (2001) \\
\hline $\mathrm{Ca}-41$ & 5 & DOE-ID (1994) & $\mathrm{Pu}-240$ & 22 & Jenkins (2001) \\
\hline $\mathrm{Cd}-109$ & 6 & DOE-ID (1994) & $\mathrm{Pu}-241 \mathrm{~d}$ & 2 & DOE-ID (2006a) \\
\hline Cd-113m & 6 & DOE-ID (1994) & $\mathrm{Pu}-242$ & 22 & Jenkins (2001) \\
\hline $\mathrm{Cl}-36$ & 0 & Jenkins (2001) & Re-187 & 10 & Jenkins (2001) \\
\hline $\mathrm{Cm}-243$ & 4000 & Jenkins (2001) & Rh-102 & 52 & Jenkins (2001) \\
\hline $\mathrm{Cm}-244$ & 4000 & Jenkins (2001) & $\mathrm{Sb}-125$ & 50 & DOE-ID (1994) \\
\hline Co-60 & 10 & DOE-ID (1994) & Se-79 & 4 & DOE-ID (1994) \\
\hline Cs-134 & 50 & DOE-ID (2006a) & Sm-151 & 240 & Jenkins (2001) \\
\hline Cs- 135 & 50 & DOE-ID (2006a) & Sn-121m & 130 & Jenkins (2001) \\
\hline
\end{tabular}


Table A-8. (continued).

\begin{tabular}{|c|c|c|c|c|c|}
\hline Radionuclide & $\begin{array}{c}\mathrm{Kd} \\
(\mathrm{mL} / \mathrm{g})\end{array}$ & $\mathrm{K}_{\mathrm{d}}$ Reference & Radionuclide & $\begin{array}{c}\mathrm{K}_{\mathrm{d}} \\
(\mathrm{mL} / \mathrm{g})\end{array}$ & $\mathrm{K}_{\mathrm{d}}$ Reference \\
\hline Cs-137 & 50 & DOE-ID (2006a) & Sn-126 & 130 & Jenkins (2001) \\
\hline Eu-152 & 340 & Jenkins (2001) & Sr-90 & 24 & DOE-ID (1994) \\
\hline Eu-154 & 340 & Jenkins (2001) & Ta-180 & 220 & Jenkins (2001) \\
\hline Eu-155 & 340 & Jenkins (2001) & Tc-99 & 0 & DOE-ID (2006a) \\
\hline Fe-55 & 220 & DOE-ID (1994) & Th-228 & 100 & DOE-ID (1994) \\
\hline $\mathrm{H}-3$ & 0 & DOE-ID (1994) & U-232 & 1.6 & DOE-ID (2006a) \\
\hline Hf- 182 & 450 & Jenkins (2001) & $\mathrm{U}-233$ & 1.6 & DOE-ID (2006a) \\
\hline $\mathrm{I}-129$ & 0 & DOE-ID (1994) & U-234 & 1.6 & DOE-ID (2006a) \\
\hline $\mathrm{K}-40$ & 15 & DOE-ID (1994) & $\mathrm{U}-235$ & 1.6 & DOE-ID (2006a) \\
\hline Mo-93 & 10 & Jenkins (2001) & U-236 & 1.6 & DOE-ID (2006a) \\
\hline $\mathrm{Nb}-93 \mathrm{~m}$ & 100 & Jenkins (2001) & $\mathrm{U}-238$ & 1.6 & DOE-ID (2006a) \\
\hline $\mathrm{Nb}-94$ & 100 & Jenkins (2001) & Zr-93 & 600 & DOE-ID (1994) \\
\hline
\end{tabular}

The parent-daughter combinations currently in use for screening calculations are illustrated for the ATR Complex inventory in Table A-9, where the daughter radionuclide is assumed to travel at the same rate as the parent, and therefore, have the same sorption coefficient as the parent. Radionuclides in parenthesis next to a parent radionuclide represent the radionuclide actually modeled because the parent is relatively short-lived and immobile and would decay long before reaching the aquifer. In these cases, the entire parent activity is conservatively converted to the equivalent progeny activity by multiplying the parent activity by the ratio of the parent half-life to progeny half-life.

Table A-9. Screening level sorption parameters for parents and daughter products. Radionuclides in parenthesis next to a parent radionuclide are the actual radionuclide modeled because the parent is relatively short-lived and immobile.

\begin{tabular}{|c|c|c|c|c|}
\hline Radionuclide & Number of Progeny & $\begin{array}{l}\text { Half-Life } \\
\text { (years) }\end{array}$ & $\begin{array}{c}\text { Ingestion Dose } \\
\text { Coefficient } \\
(\mathrm{rem} / \mathrm{Ci})\end{array}$ & $\begin{array}{c}\mathrm{K}_{\mathrm{d}} \text { in the } \\
\text { Unsaturated Zone } \\
(\mathrm{mL} / \mathrm{g})\end{array}$ \\
\hline Ag-108m & 0 & $1.270 \mathrm{E}+02$ & $8.736 \mathrm{E}+03$ & $9.000 \mathrm{E}+01$ \\
\hline Am-241(Np-237) & 2 & $2.140 \mathrm{E}+06$ & $3.959 \mathrm{E}+05$ & $2.000 \mathrm{E}+00$ \\
\hline U-233 & 0 & $1.592 \mathrm{E}+05$ & $1.897 \mathrm{E}+05$ & \\
\hline Th-229 & 0 & $7.340 \mathrm{E}+03$ & $1.850 \mathrm{E}+06$ & \\
\hline $\mathrm{Cm}-244(\mathrm{Pu}-240)$ & 4 & $6.537 \mathrm{E}+03$ & $9.276 \mathrm{E}+05$ & $2.200 \mathrm{E}+01$ \\
\hline U-236 & 0 & $2.342 \mathrm{E}+07$ & $1.734 \mathrm{E}+05$ & \\
\hline Th-232 & 0 & $1.405 \mathrm{E}+10$ & $8.536 \mathrm{E}+05$ & \\
\hline Ra-228 & 0 & $5.750 \mathrm{E}+00$ & $2.579 \mathrm{E}+06$ & \\
\hline Th-228 & 0 & $1.912 \mathrm{E}+00$ & $2.665 \mathrm{E}+05$ & \\
\hline Co- 60 & 0 & $5.271 \mathrm{E}+00$ & $1.265 \mathrm{E}+04$ & $1.000 \mathrm{E}+01$ \\
\hline Cs-134 & 0 & $2.062 \mathrm{E}+00$ & $7.119 \mathrm{E}+04$ & $5.000 \mathrm{E}+01$ \\
\hline Cs-137 & 0 & $3.000 \mathrm{E}+01$ & $5.017 \mathrm{E}+04$ & $5.000 \mathrm{E}+01$ \\
\hline Eu-152 & 0 & $1.333 \mathrm{E}+01$ & $5.062 \mathrm{E}+03$ & $3.400 \mathrm{E}+02$ \\
\hline Eu-154 & 0 & $8.800 \mathrm{E}+00$ & $7.559 \mathrm{E}+03$ & $3.400 \mathrm{E}+02$ \\
\hline Eu-155 & 0 & $4.960 \mathrm{E}+00$ & $1.204 \mathrm{E}+03$ & $3.400 \mathrm{E}+02$ \\
\hline
\end{tabular}


Table A-9. (continued).

\begin{tabular}{|c|c|c|c|c|}
\hline Radionuclide & Number of Progeny & $\begin{array}{c}\text { Half-Life } \\
\text { (years) }\end{array}$ & $\begin{array}{c}\text { Ingestion Dose } \\
\text { Coefficient } \\
\text { (rem/Ci) }\end{array}$ & $\begin{array}{c}\mathrm{K}_{\mathrm{d}} \text { in the } \\
\text { Unsaturated Zone } \\
(\mathrm{mL} / \mathrm{g})\end{array}$ \\
\hline $\mathrm{H}-3$ & 0 & $1.235 \mathrm{E}+01$ & $7.089 \mathrm{E}+01$ & \\
\hline $\mathrm{Pu}-238(\mathrm{U}-234)$ & 3 & $2.455 \mathrm{E}+05$ & $1.832 \mathrm{E}+05$ & $1.600 \mathrm{E}+00$ \\
\hline Th-230 & 0 & $7.538 \mathrm{E}+04$ & $7.911 \mathrm{E}+05$ & \\
\hline Ra-226 & 0 & $1.600 \mathrm{E}+03$ & $1.035 \mathrm{E}+06$ & \\
\hline $\mathrm{Pb}-210$ & 0 & $2.230 \mathrm{E}+01$ & $2.576 \mathrm{E}+06$ & \\
\hline $\mathrm{Pu}-239$ & 3 & $2.407 \mathrm{E}+04$ & $9.276 \mathrm{E}+05$ & $2.200 \mathrm{E}+01$ \\
\hline U-235 & 0 & $7.038 \mathrm{E}+08$ & $1.728 \mathrm{E}+05$ & $1.600 \mathrm{E}+00$ \\
\hline $\mathrm{Pa}-231$ & 0 & $3.276 \mathrm{E}+04$ & $1.772 \mathrm{E}+06$ & \\
\hline Ac- 227 & 0 & $2.177 \mathrm{E}+01$ & $1.194 \mathrm{E}+06$ & \\
\hline Sr-90 & 0 & $2.912 \mathrm{E}+01$ & $1.024 \mathrm{E}+05$ & $2.400 \mathrm{E}+01$ \\
\hline Th-228 & 0 & $1.913 \mathrm{E}+00$ & $2.665 \mathrm{E}+05$ & $1.000 \mathrm{E}+02$ \\
\hline Th-230 & 2 & $7.538 \mathrm{E}+04$ & $7.911 \mathrm{E}+05$ & $1.000 \mathrm{E}+02$ \\
\hline Ra-226 & 0 & $1.600 \mathrm{E}+03$ & $1.035 \mathrm{E}+06$ & \\
\hline $\mathrm{Pb}-210$ & 0 & $2.230 \mathrm{E}+01$ & $2.576 \mathrm{E}+06$ & \\
\hline Th-232 & 2 & $1.405 \mathrm{E}+10$ & $8.536 \mathrm{E}+05$ & $1.000 \mathrm{E}+02$ \\
\hline Ra-228 & 0 & $5.750 \mathrm{E}+00$ & $2.579 \mathrm{E}+06$ & \\
\hline Th-228 & 0 & $1.912 \mathrm{E}+00$ & $2.665 \mathrm{E}+05$ & \\
\hline U-234 & 3 & $2.445 \mathrm{E}+05$ & $1.832 \mathrm{E}+05$ & $1.600 \mathrm{E}+00$ \\
\hline Th-230 & 0 & $7.538 \mathrm{E}+04$ & $7.911 \mathrm{E}+05$ & \\
\hline Ra-226 & 0 & $1.600 \mathrm{E}+03$ & $1.035 \mathrm{E}+06$ & \\
\hline $\mathrm{Pb}-210$ & 0 & $2.230 \mathrm{E}+01$ & $2.576 \mathrm{E}+06$ & \\
\hline U-235 & 2 & $7.038 \mathrm{E}+08$ & $1.728 \mathrm{E}+05$ & $1.600 \mathrm{E}+00$ \\
\hline $\mathrm{Pa}-231$ & 0 & $3.276 \mathrm{E}+04$ & $1.772 \mathrm{E}+06$ & \\
\hline Ac- 227 & 0 & $2.177 \mathrm{E}+01$ & $1.194 \mathrm{E}+06$ & \\
\hline U-238 & 4 & $4.468 \mathrm{E}+09$ & $1.648 \mathrm{E}+05$ & $1.600 \mathrm{E}+00$ \\
\hline U-234 & 0 & $2.455 \mathrm{E}+05$ & $1.832 \mathrm{E}+05$ & \\
\hline Th-230 & 0 & $7.538 \mathrm{E}+04$ & $7.911 \mathrm{E}+05$ & \\
\hline Ra-226 & 0 & $1.600 \mathrm{E}+03$ & $1.035 \mathrm{E}+06$ & \\
\hline $\mathrm{Pb}-210$ & 0 & $2.230 \mathrm{E}+01$ & $2.576 \mathrm{E}+06$ & \\
\hline
\end{tabular}

Evolving understanding of sediment composition and of its influence on $\mathrm{K}_{\mathrm{d}} \mathrm{s}$ has since resulted in revising many of the values. In most cases, the historically used values shown in Column 3 of Table A-10 are very conservative compared to the recommended value reported in INL-2010b. Of significance are the differences in plutonium $\mathrm{K}_{\mathrm{d}} \mathrm{s}$ recommended by the Track 2 guidance (DOE-ID 1994), Jenkins (2001), and INL 2010b (Table A-10). The lowest value appearing for plutonium is $22 \mathrm{~mL} / \mathrm{g}$, with a high of $1,500 \mathrm{~mL} / \mathrm{g}$ (used in the ATR Complex analysis). The value used in the ATR Complex analysis exceeds the currently recommended value of $1,250 \mathrm{~mL} / \mathrm{g}$ (INL 2010b), and the value used in the earlier assessment at NRF $(22 \mathrm{~mL} / \mathrm{g})$ includes very little sorption by using a number that corresponds to crushed basalt (DOE-ID 1994) rather than using the much higher value representative of soil- and clay-bearing sedimentary interbed materials. 
Table A-10. Distribution coefficients recommended for use by the remote-handled low-level waste disposal facility for key radionuclides also present in upgradient sources compared to those used in previous remedial investigations and feasibility studies for ATR Complex and NRF.

\begin{tabular}{|c|c|c|c|c|}
\hline \multirow[b]{2}{*}{ Element } & \multicolumn{4}{|c|}{ Distribution Coefficients, $\mathrm{K}_{\mathrm{d}}(\mathrm{mL} / \mathrm{g})$} \\
\hline & $\begin{array}{l}\text { Recommended in } \\
\text { INL 2010b }\end{array}$ & $\begin{array}{l}\text { Historically used values } \\
\text { from Table A-8 }\end{array}$ & $\begin{array}{l}\text { Values used in the } \\
\text { ATR Complex } \\
\text { Comprehensive RI/FS }\end{array}$ & $\begin{array}{l}\text { Values used in the } \\
\text { NRF } \\
\text { Comprehensive RI/FS }\end{array}$ \\
\hline Ac & 300 & 450 & & \\
\hline $\mathrm{C}$ & 0.5 & 0 & & 1.2 \\
\hline $\mathrm{Cl}$ & 0 & 0 & & \\
\hline $\mathrm{H}$ & 0 & 0 & & \\
\hline I & 6.1 & 0 & & \\
\hline Mo & 10 & 10 & & \\
\hline $\mathrm{Nb}$ & 160 & 100 & & \\
\hline $\mathrm{Ni}$ & 100 & 100 & & \\
\hline No & 17.5 & 2 & & 22 \\
\hline $\mathrm{Pa}$ & 550 & 550 & & \\
\hline $\mathrm{Pb}$ & 270 & & & \\
\hline $\mathrm{Pu}$ & 1250 & 22 & 1500 & 22 \\
\hline $\mathrm{Ra}$ & 500 & & & \\
\hline $\mathrm{Tc}$ & 0.1 & 0 & & \\
\hline Th & 500 & 100 & 100 & \\
\hline U & 10 & 1.6 & 6 & 6 \\
\hline
\end{tabular}

\section{A-6.5 Dose Coefficients}

CERCLA analyses and decisions for the ATR Complex and NRF were based on groundwater protection standards determined by the Environmental Protection Agency and the State of Idaho couched in terms of MCLs, in addition to a calculated cancer risk and hazard quotient. Federal MCLs found in 40 CFR 141 include values for beta-gamma emitting radionuclides and alpha-emitting radionuclides. The maximum concentration level for beta-gamma emitting radionuclides is the concentration that, assuming an ingestion rate of $2 \mathrm{~L}$ of water per day for 365 days per year, the dose equivalent to the whole body or critical organ does not exceed $4 \mathrm{mrem} / \mathrm{year}^{\mathrm{a}}$. Other specific limits include a maximum gross alpha activity of $15 \mathrm{pCi} / \mathrm{L}$ (excluding radon and uranium isotopes), a maximum combined $\mathrm{Ra}-226$ and $\mathrm{Ra}-228$

concentration of $5 \mathrm{pCi} / \mathrm{L}$, a maximum uranium mass concentration of $30 \mu \mathrm{g} / \mathrm{L}$, and maximum $\mathrm{H}-3$ and $\mathrm{Sr}-$ 90 concentrations of $20,000 \mathrm{pCi} / \mathrm{L}$ and $8 \mathrm{pCi} / \mathrm{L}$, respectively. Cancer risk calculations include consideration of an exposure scenario, allowing determination of net probability through groundwater ingestion, food crop ingestion through irrigation, direct exposure, and dust inhalation, etc. These risks are cumulative across radionuclides and sources of radionuclides.

The groundwater protection standard used under DOE Order 435.1 corresponds to the all-pathways EDE. The all-pathways EDE considers not only the dose received by direct ingestion of groundwater, but

${ }^{a}$ Calculated using 168-hour data listed in Maximum Permissible Body Burdens and Maximum Permissible Concentration of Radionuclides in Air or Water for Occupational Exposure. NBS Handbook 69 as amended August 1963. U.S. Department of Commerce 
the dose from using groundwater to irrigate human and animal crops and water animals. The all-pathways dose includes dose from ingestion of locally grown crops, locally raised beef, and locally produced milk.

The all-pathways dose is summarized in terms of the all-pathways dose per unit concentration in groundwater. With these factors, the dose can be calculated by multiplying the predicted groundwater concentration by the all-pathways dose factor:

$D=C_{G W} \times D F$

where

$D=$ annual all-pathways dose (EDE) from the groundwater pathway (mrem/year)

$C_{G W}=$ radionuclide concentration in groundwater $\left(\mathrm{Ci} / \mathrm{m}^{3}\right)$

$D F=$ all-pathways dose factor from DOE-ID (2007) (mrem- $\mathrm{m}^{3} / \mathrm{Ci}$-year).

Using an all-pathways EDE dose for the assessment allows the cumulative effects across all radionuclides. Additionally, the predicted all-pathways dose from individual sources can be added to the all-pathways dose from other facilities. The all-pathways EDE is the currently accepted performance measure used by DOE to determine the suitability of low-level radioactive disposal facilities.

In general, the all-pathways dose is estimated by

$D F=C_{G W} \times\left(C R_{\text {veg }} \times I_{\text {veg }}+C R_{\text {forg }} I_{\text {forg }} T C_{\text {milk }} \times I_{\text {milk }}+C R_{\text {forg }} I_{\text {forg }} T C_{\text {beef }} \times I_{\text {beef }}+I_{\text {wat }}\right) D C F(\mathrm{~A}-3)$

where $C R=$ concentration ratio in vegetables and forage, $T C=$ transfer coefficients from feed to milk and beef, $I=$ human and animal intake rates of vegetables, forage, milk, beef, and water, and $D C F=$ the dose coefficient.

Details of the all-pathways methodology and parameter values are described in the RWMC performance assessment (DOE-ID 2007) and the ICDF landfill performance assessment (DOE-ID 2010).

All-pathways doses reported in the 2003 ICDF composite analysis (DOE-ID 2003b) used dose coefficients from EPA (1988). These dose coefficients have been superseded by dose coefficients from Federal Guidance Report 13 (EPA 1999) supplied in the FGR-13 CD supplement (EPA 2002). For fission and activation products, there was little change in the dose coefficients. However, for some of the actinides (plutonium isotopes in particular), the dose coefficients changed substantially, and in most cases, decreased. The all-pathways dose factors used in this assessment reflect these changes. The allpathways dose factors used in this assessment and those used in the 2003 ICDF composite analysis are presented with the results in the next section.

\section{A-7. COMPUTATION OF DOSE FOR TIME PERIODS OF INTEREST TO THE REMOTE-HANDLED LOW-LEVEL WASTE DISPOSAL FACILITY}

In general, the previously used parameters result in overly conservative results that maximize contaminant impacts to the aquifer, whereas the parameters discussed in Section A-6 should result in less conservative, but more realistic groundwater impacts (e.g., partition coefficients). Other parameter combinations are less difficult to predict without simulation. For example, the combination of longerlived daughter products and lower infiltration rates will allow increased ingrowth of progeny. Because of the immediate position of NRF and the ATR Complex upgradient of the proposed RH-LLW disposal facility Site 5, the following subsections provide the model predicted groundwater impacts for both facilities using the more current parameter set.

The re-analyses presented in the following subsections are based on the fundamental conceptual model used in the comprehensive RI/FS for NRF and the ATR Complex shown in Figure A-2 and discussed in Sections A-3 through A-5. This process model assumes that contaminants in surficial soils at 
land surface and in perched water above the first basalt contact could be transported downward through the remaining alluvium and stratigraphic layers comprising the vadose zone by infiltration from natural precipitation and from water discharged to infiltration ponds. Along this transport pathway, the dilute radionuclides can undergo advection, sorption, dispersion, and radioactive chain decay and ingrowth. Once in the aquifer, similar transport and decay processes occur as contaminants move with the regional groundwater flow.

Parameters used to compute concentrations for use by the RH-LLW groundwater impacts analysis have been updated relative to the initial model parameterization based on the discussions presented in Section A-6. In addition to peak concentrations, the all-pathways doses have been computed for NRF and the ATR Complex. These are required to complete the cumulative impacts analysis required by DOE Order 435.1. Parameters related to source inventory and dimensions were retained in analyses shown in Sections A-7.1 and A-7.2 from the comprehensive RI/FS for NRF (Westinghouse 1997) and the comprehensive RI/FS for the ATR Complex (DOE-ID 1997b). Other properties used are presented with results in the following subsections.

\section{A-7.1 Evaluation of the All-Pathways Effective Dose Equivalent for the Naval Reactors Facility}

The computation of the all-pathways dose for historically significant releases at NRF was performed using the MCM (Rood 2005) and GWSCREEN Ver 2.5 (Rood 2003) codes, $\mathrm{K}_{\mathrm{d}}$ data from DOEID (2010c) (given in Table A-10), lithology discussed in Section A-6.3, and all-pathways dose factors from DOE-ID (2007) and DOE-ID (2010), which implement dose coefficients from FGR-13 (EPA 1999, EPA 2002). The infiltration rate was assumed to begin at $18 \mathrm{~cm} /$ year, derived from the analyses of the INTEC tank farm (DOE-ID 2006a), linearly decreasing to an ambient background level of $1 \mathrm{~cm} /$ year during the first 100 years of simulation. The initial value of $18 \mathrm{~cm} /$ year represents disturbed soil conditions in course material and is more conservative than the value used in the Subsurface Disposal Area model. The final value represents compacted or undisturbed soil conditions.

Soil properties used for the alluvium were applied to the source zone because contaminated soils at NRF reside in the alluvium. Van Genuchten parameters were used with a Mualem model to represent high-permeability INTEC alluvium (DOE-ID 2006a). High-permeability alluvium was chosen over low-permeability alluvium because of the conservatism introduced. Properties for interbeds were determined by the U.S. Geological Survey for well ICPP-SCI-V-214 (DOE-ID 2004, DOE-ID 2008). Unsaturated basalt properties were documented in Magnuson (1995) and Wood et al. (2007). Properties for the basalt fractures were derived from the INL Large-Scale Infiltration Test and were documented in Magnuson (1995). Fractured basalt parameters retained the saturated conductivity, residual saturation, and total porosity presented in Magnuson (1995). Unsaturated moisture characteristic parameters for the Van Genuchten (1980) relationship were selected to allow ready drainage at low moisture content and rapid increase in relative conductivity at low saturation. Using a low alpha $\left(2.5 \mathrm{~m}^{-1}\right)$ and high $\mathrm{n}(10)$ is consistent with the Brooks-Corey parameters developed by Magnuson (1995). These soil properties are shown in Table A-11.

Other model parameters are summarized in Table A-12, including the parameter description in Column 1, the value used in the assessment in Column 2, and a comment in Column 3 providing the origin of previously derived information.

Predicted peak groundwater concentrations are presented in Table A-13 computed using MCM and GWSCREEN and the parameters listed in Tables A-1, A-11, and A-12. The values in parentheses represent the peak groundwater concentrations and time of peak concentration as reported in the comprehensive RI/FS for NRF (Westinghouse 1997) and were also shown in the ICDF composite analysis (DOE-ID 2003a). 
Table A-11. Hydraulic parameters used to represent flow in the source zone and vadose zone models.

\begin{tabular}{|c|c|c|c|c|c|c|c|c|c|}
\hline Lithology & $\begin{array}{l}\text { Saturated } \\
\text { Hydraulic } \\
\text { Conductivity } \\
\text { (m/year) } \\
\end{array}$ & $\begin{array}{c}\text { Total } \\
\text { Porosity }\end{array}$ & $\begin{array}{l}\text { Residual } \\
\text { Moisture } \\
\text { Content }\end{array}$ & $\begin{array}{l}\text { Van } \\
\text { Genuchten } \\
\text { Fitting } \\
\text { Parameter } \\
n \\
\end{array}$ & $\begin{array}{l}\text { Van } \\
\text { Genuchten } \\
\text { Fitting } \\
\text { Parameter } \alpha \\
(1 / \mathrm{m})\end{array}$ & $\begin{array}{l}\text { Van } \\
\text { Genuchten } \\
\text { Fitting } \\
\text { Parameter } \\
m \\
\end{array}$ & $\begin{array}{l}\text { Mualem } \\
\text { Fitting } \\
\text { Parameter } \\
\quad L \\
\end{array}$ & $\begin{array}{c}\text { Bulk } \\
\text { Density } \\
\left(\mathrm{g} / \mathrm{cm}^{3}\right) \\
\end{array}$ & Reference \\
\hline Alluvium and source zone & 8,798 & 0.32 & 0.0002 & 1.4 & 100 & 0.29 & 0.5 & 1.82 & DOE-ID (2006a) \\
\hline Interbed & 1.05 & 0.459 & 0.163 & 1.48 & 0.062 & 0.69 & 9.33 & 1.5 & $\begin{array}{l}\text { Based on best fit of hydraulic } \\
\text { data from well ICPP-SCI-V-214 } \\
\text { (39-ft) (DOE-ID 2004), bulk } \\
\text { density (DOE-ID 1994) }\end{array}$ \\
\hline Unsaturated basalt & $91(300 \mathrm{mDarcy})^{\mathrm{a}}$ & $0.05^{\mathrm{a}}$ & $0.001^{\mathrm{a}}$ & $10^{\mathrm{b}}$ & $2.5^{\mathrm{b}}$ & $0.90^{\mathrm{b}}$ & $0.5^{\mathrm{b}}$ & 2 & $\begin{array}{l}\text { See footnotes, bulk density } \\
\text { assumed }\end{array}$ \\
\hline
\end{tabular}

a. From Magnuson (1995) who originally used a residual moisture content of 0.0, but subsequently increased it to 0.01 in the OU 7-13/14 RI/BRA (DOE-ID 2006b).

b. Parameters determined for the Van Genuchten model to mimic the behavior of the Magnuson (1995) hydraulic relationships for fractured basalt at low saturation. 
Table A-12. Input parameters for the Naval Reactors Facility re-analysis.

\begin{tabular}{|c|c|c|}
\hline Parameter Description & Value & Comments \\
\hline $\begin{array}{l}\text { Source length parallel to } \\
\text { groundwater flow }\end{array}$ & $100 \mathrm{~m}$ & $\begin{array}{l}\text { Average source length for the six radionuclides analyzed } \\
\text { (rounded) }\end{array}$ \\
\hline $\begin{array}{l}\text { Source width perpendicular to } \\
\text { groundwater flow }\end{array}$ & $49 \mathrm{~m}$ & $\begin{array}{l}\text { Average source length for the six radionuclides analyzed } \\
\text { (rounded) }\end{array}$ \\
\hline Receptor distance & 50 & One-half the source length \\
\hline Infiltration, 0 to 100 years & $\begin{array}{l}18 \mathrm{~cm} / \text { year linearly } \\
\text { decreasing to } 1 \mathrm{~cm} / \text { year }\end{array}$ & $\begin{array}{l}\text { Conservatively assumed based on infiltration through } \\
\text { disturbed soils at INTEC }\end{array}$ \\
\hline Infiltration, greater than 100 years & $1 \mathrm{~cm} /$ year & Background infiltration in undisturbed soil \\
\hline Unsaturated lithology, 0 to $10 \mathrm{~m}$ & 4 cells, $2.5 \mathrm{~m} /$ cell & High-permeability alluvium \\
\hline Unsaturated lithology, 10 to $50 \mathrm{~m}$ & 15 cells, $2.5 \mathrm{~m} /$ cell & Unsaturated basalt \\
\hline Unsaturated lithology, 50 to $52.8 \mathrm{~m}$ & 2 cells, $1.4 \mathrm{~m} /$ cell & Interbed \\
\hline $\begin{array}{l}\text { Unsaturated lithology, } 52.8 \text { to } 95.3 \\
\mathrm{~m}\end{array}$ & 17 cells, $2.5 \mathrm{~m} /$ cell & Unsaturated basalt \\
\hline Unsaturated dispersivity & $1.25 \mathrm{~m}$ & $\begin{array}{l}\text { Implicit dispersion calculated with Equation } 24 \text { in Rood } \\
(2005) \text { as } \alpha=Z / 2 N \text { where } Z=\text { unsaturated thickness } \\
(95.3 \mathrm{~m}) \text { and } N=\text { number of cells }(38)\end{array}$ \\
\hline Darcy Velocity in aquifer & $25.3 \mathrm{~m} /$ year & $\begin{array}{l}\text { Record of decision for NRF OU 8-08 number } \\
\text { AR5,1-10544 }\end{array}$ \\
\hline Aquifer porosity & 0.06 & OU 10-08 (DOE-ID 2008b) \\
\hline Bulk density of aquifer & $1.9 \mathrm{~g} / \mathrm{cm}^{3}$ & DOE-ID (1994, p. C-11) \\
\hline Longitudinal dispersivity & $10 \mathrm{~m}$ & $\begin{array}{l}\text { Record of decision for NRF OU 8-08 number } \\
\text { AR5,1-10544 }\end{array}$ \\
\hline Transverse dispersivity & $1 \mathrm{~m}$ & $\begin{array}{l}\text { Record of decision for NRF OU 8-08 number } \\
\text { AR5,1-10544 }\end{array}$ \\
\hline
\end{tabular}

Table A-13. Predicted peak radionuclide groundwater concentrations for the re-analysis of the comprehensive groundwater impacts at the Naval Reactors Facility.

\begin{tabular}{llrr}
\hline Radionuclide & Progeny & $\begin{array}{c}\text { Peak Concentration } \\
(\mathrm{pCi} / \mathrm{L})\end{array}$ & $\begin{array}{c}\text { Time of Peak after Start of Simulation }^{\mathrm{b}} \\
\text { (years) }\end{array}$ \\
\hline $\mathrm{U}-235$ & & $2.45 \mathrm{E}-05(0.344)$ & $74750(1268)$ \\
& Pa-231 & $5.20 \mathrm{E}-07$ & 206000 \\
$\mathrm{U}-234$ & Ac-227 & $6.07 \mathrm{E}-07$ & 206000 \\
& & $4.90 \mathrm{E}-02(3.17)$ & $24750(1416)$ \\
& Th-230 & $2.02 \mathrm{E}-04$ & 43750 \\
& Ra-226 & $1.95 \mathrm{E}-04$ & 49750 \\
Np-237 & $2.36 \mathrm{E}-04$ & 49750 \\
& Pb-210 & $2.53 \mathrm{E}-09(0.649)$ & $90000(5274)$ \\
& & $1.34 \mathrm{E}-02$ & 56750 \\
& $\mathrm{U}-233$ & $2.90 \mathrm{E}-04$ & 90000 \\
\hline
\end{tabular}


Table A-13. (continued).

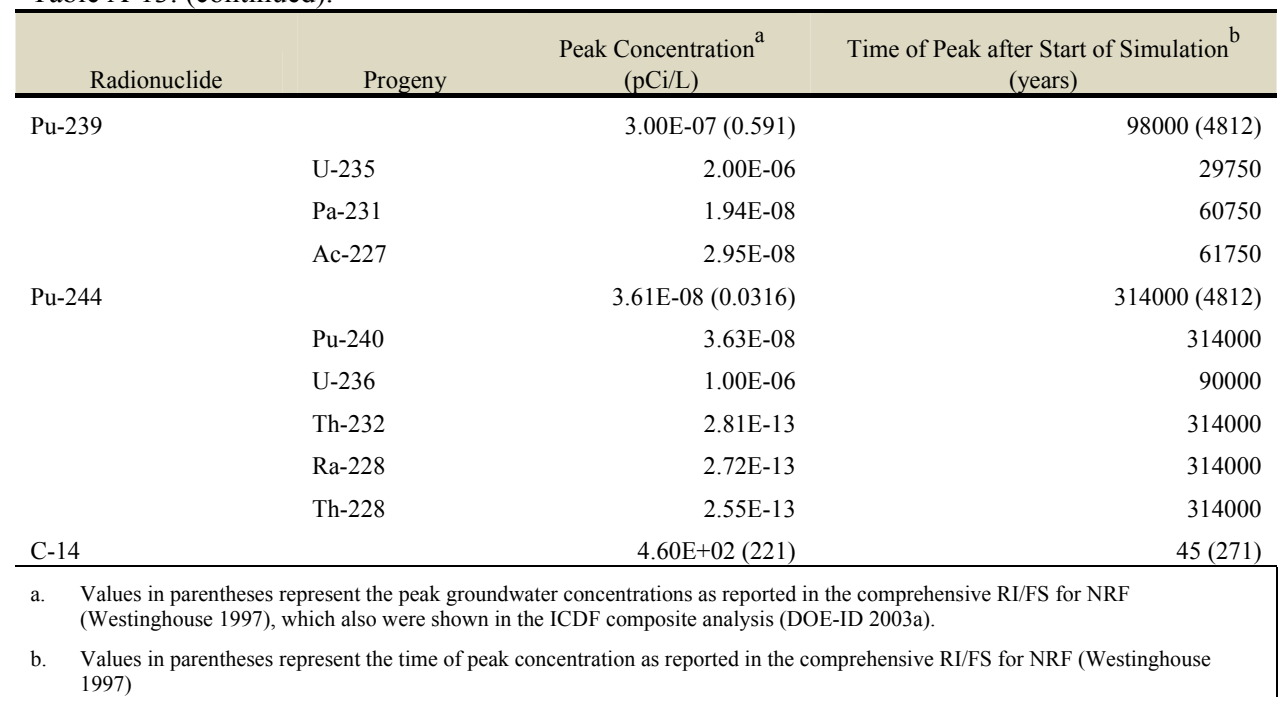

With the exception of $\mathrm{C}-14$, the predicted concentrations using current understanding of parameters at INL are orders of magnitude lower than those reported in the original analysis. The exception, based on the current parameterization, is that the predicted concentration of $\mathrm{C}-14$ is about two times higher than originally predicted, with the $\mathrm{C}-14$ arriving 45 years from the beginning of simulation instead of the originally predicted 271 years as reported in Westinghouse (1997). This difference is due to a lower $\mathrm{K}_{\mathrm{d}}$ currently being recommended for C-14 as shown in Table A-10.

Groundwater concentrations reported for the comprehensive RI/FS for NRF (Westinghouse 1997) were used to calculate an all-pathways dose in the ICDF CA (DOE-ID 2003b). The all-pathways doses reported in the 2003 ICDF composite analysis are reproduced in Column 5 of Table A-14. They were calculated using the all-pathways dose model in DOE 2003a and dose coefficients from EPA 1988 (shown in Column 3, Table A-14) instead of the current dose coefficients from FGR-13 (EPA 2002) and shown in Column 4 of Table A-14. The difference in dose coefficients for the radionuclides of importance to the RH-LLW disposal facility are significant as shown by the comparison of values in Columns 3 and 4 in Table A-14.

With the exception of C-14, all doses in the NRF re-analysis (Column 6 of Table A-14) are several orders of magnitude lower than those calculated in support of the ICDF composite analysis (Column 5 of Table A-14). Consistent with the higher groundwater concentrations, the newly predicted C-14 all-pathways dose is about a factor of two higher with the peak occurring at 45 years from the start of the simulation compared to 271 years as reported in the ICDF composite analysis (DOE-ID 2003b).

All-pathways doses were computed at the downgradient edge of the source at NRF. NRF is roughly 5 miles north of the proposed Site 5 for the RH-LLW disposal facility. In the intervening distance, dilution and dispersion would further reduce the dose once the radionuclides reached the RH-LLW disposal facility location. Thus, the doses from NRF have very little chance of impacting the proposed Site 5 location of the RH-LLW disposal facility. 
Table A-14. Predicted all-pathways dose for the re-analysis of cumulative groundwater impacts at the Naval Reactors Facility. For comparison, the all-pathways dose and dose factor from the 2003 ICDF composite analysis (DOE-ID 2003b) also are presented.

\begin{tabular}{|c|c|c|c|c|c|}
\hline \multirow[b]{2}{*}{ Radionuclide } & \multirow[b]{2}{*}{ Progeny } & \multicolumn{2}{|c|}{$\begin{array}{l}\text { All-Pathways Dose Factor } \\
\text { (rem-m } \mathrm{m}^{3} / \text { Ci-year) }\end{array}$} & \multicolumn{2}{|c|}{$\begin{array}{l}\text { Peak All-Pathways Dose (mrem/year EDE) } \\
\text { Peak Time in Parentheses }\end{array}$} \\
\hline & & $\begin{array}{c}\text { EPA } 1988 \\
\text { (ICDF 2003 composite } \\
\text { analysis) }\end{array}$ & $\begin{array}{l}E P A \\
2002 \\
\end{array}$ & $\begin{array}{l}2003 \text { ICDF composite } \\
\text { analysis }\end{array}$ & $\begin{array}{l}\text { Re-analysis using current } \\
\text { parameters }\end{array}$ \\
\hline $\mathrm{C}-14$ & & $5.88 \mathrm{e} 3$ & $5.55 \mathrm{e} 3$ & $1.3(271$ years $)$ & 2.56 (45 years) \\
\hline \multirow[t]{3}{*}{ Np-237 } & & $3.42 \mathrm{e} 6$ & $3.05 \mathrm{e} 5$ & & $7.7 \mathrm{e}-10$ \\
\hline & $\mathrm{U}-233$ & $2.34 \mathrm{e} 5$ & $1.54 \mathrm{e} 5$ & & $2.1 \mathrm{e}-3$ \\
\hline & Th-229 & $3.1 \mathrm{e} 6$ & $1.82 \mathrm{e} 6$ & & $5.3 e-4$ \\
\hline Np-237 Total & & & & $1.87(5,274$ years $)$ & $2.59 \mathrm{e}-3$ (70,750 years) \\
\hline \multirow[t]{4}{*}{$\mathrm{Pu}-239$} & & $2.71 \mathrm{e} 6$ & $7.1 \mathrm{e} 5$ & & $2.1 \mathrm{e}-7$ \\
\hline & U-235 & $2.16 \mathrm{e} 5$ & $1.41 \mathrm{e} 5$ & & $2.8 \mathrm{e}-7$ \\
\hline & $\mathrm{Pa}-231$ & $8.1 \mathrm{e} 6$ & $1.36 \mathrm{e} 6$ & & $2.6 \mathrm{e}-8$ \\
\hline & Ac- 227 & $1.13 \mathrm{e} 7$ & $3.01 \mathrm{e} 7$ & & $8.9 \mathrm{e}-7$ \\
\hline Pu-239 Total & & & & $1.87(4,822$ years $)$ & $1.23 \mathrm{e}-6(59,750$ years $)$ \\
\hline \multirow[t]{6}{*}{$\mathrm{Pu}-244^{\mathrm{a}}$} & & $2.5 \mathrm{e} 6$ & $2.5 \mathrm{e} 6$ & & $9.2 \mathrm{e}-8$ \\
\hline & $\mathrm{Pu}-240$ & & $7.1 \mathrm{e} 5$ & & $2.6 \mathrm{e}-8$ \\
\hline & $\mathrm{U}-236$ & $2.17 \mathrm{e} 5$ & $1.4 \mathrm{e} 5$ & & $1.4 \mathrm{e}-7$ \\
\hline & Th-232 & $2.09 \mathrm{e} 6$ & $6.54 \mathrm{e} 5$ & & $1.8 \mathrm{e}-13$ \\
\hline & Ra-228 & $1.15 \mathrm{e} 6$ & $2.07 \mathrm{e} 6$ & & $5.6 \mathrm{e}-13$ \\
\hline & Th-228 & $6.19 \mathrm{e} 5$ & $4.04 \mathrm{e} 5$ & & $1.0 \mathrm{e}-13$ \\
\hline $\mathrm{Pu}-244$ Total & & & & 7.9e-5 (4,812 years) & $2.48 \mathrm{e}-7$ ( 316,065 years $)$ \\
\hline \multirow[t]{4}{*}{$\mathrm{U}-234$} & & $2.29 \mathrm{e} 5$ & $1.46 \mathrm{e} 5$ & & $7.3 e-3$ \\
\hline & Th-230 & $4.19 \mathrm{e} 5$ & $6.05 \mathrm{e} 5$ & & $1.2 \mathrm{e}-4$ \\
\hline & $\mathrm{Ra}-226$ & $1.06 \mathrm{e} 6$ & $8.26 \mathrm{e} 5$ & & $1.6 \mathrm{e}-4$ \\
\hline & $\mathrm{Pb}-210$ & $5.76 \mathrm{e} 6$ & $7.35 \mathrm{e} 7$ & & $1.7 \mathrm{e}-2$ \\
\hline U-234 Total & & & & $6.41 \mathrm{e}-1(1,416)$ & $1.95 \mathrm{e}-2(40,750)$ \\
\hline \multirow[t]{3}{*}{$\mathrm{U}-235$} & & $2.16 \mathrm{e} 5$ & $1.41 \mathrm{e} 5$ & & $3.5 \mathrm{e}-6$ \\
\hline & $\mathrm{Pa}-231$ & $8.1 \mathrm{e} 6$ & $1.36 \mathrm{e} 6$ & & 7.1e-7 \\
\hline & Ac-227 & $1.13 \mathrm{e} 7$ & $3.01 \mathrm{e} 7$ & & $1.8 \mathrm{e}-5$ \\
\hline U-235 Total & & & & $6.51 \mathrm{e}-2(1,268)$ & $2.24 \mathrm{e}-5(206,000)$ \\
\hline
\end{tabular}

\section{A-7.2 Evaluation of All-Pathways Effective Dose Equivalent for the Advanced Test Reactor Complex}

To reduce the numbers of radionuclides to those with the greatest potential to contribute to significant groundwater impacts at the ATR Complex, a screening approach was first taken. The screening approach evaluated the drinking water dose that would occur to a potential receptor if water were ingested at a rate of $2 \mathrm{~L} /$ day and using dose coefficients from EPA (2002). The GWSCREEN model was parameterized with values provided in Tables A-7 and A-9 and the inventories shown in Columns 13 and 14 of 
Table A-2. With the exception of source dimensions, sediment thickness, and distance to receptor, the non-radionuclide parameters correspond to Track 2 default parameters (DOE-ID 1994). The distribution coefficients used in the screening step were conservative screening level values. In this screening step, radionuclides with drinking water doses greater than $0.4 \mathrm{mrem} /$ year were retained for further evaluation; the MCL typically corresponds to $4 \mathrm{mrem} / \mathrm{year}$.

Results of the screening analysis are shown in Table A-15. Radionuclides with doses greater than $0.4 \mathrm{mrem} /$ year were U-238, U-234, and Pu-239. Th-230 was retained because its screening dose was close $(0.3 \mathrm{mrem} /$ year $)$ to the $0.4 \mathrm{mrem} /$ year dose criteria. Tritium was screened out from further consideration because its relatively short half-life (12.3 years) precludes its significance in terms of long-term dose impacts.

Table A-15. Results of radionuclide screening for the Advanced Test Reactor Complex surface soils inventories.

\begin{tabular}{|c|c|c|c|}
\hline Radionuclide & Progeny & $\begin{array}{l}\text { Drinking Water EDE } \\
\text { (mrem) }\end{array}$ & $\begin{array}{c}\text { Time of Peak After Start of Simulation } \\
\text { (years) }\end{array}$ \\
\hline $\mathrm{Ag}-108 \mathrm{~m}$ & & $4.50 \mathrm{E}-61$ & 24,326 \\
\hline \multirow[t]{3}{*}{ Am-241(Np-237) } & & $1.18 \mathrm{E}-04$ & \\
\hline & $\mathrm{U}-233$ & $1.43 \mathrm{E}-07$ & \\
\hline & Th-229 & $3.77 \mathrm{E}-08$ & \\
\hline Total Am-241 & & $1.18 \mathrm{E}-01$ & 583 \\
\hline \multirow[t]{5}{*}{$\mathrm{Cm}-244(\mathrm{Pu} 240$} & & $1.18 \mathrm{E}-05$ & \\
\hline & U-236 & $5.47 \mathrm{E}-10$ & \\
\hline & Th-232 & $4.39 \mathrm{E}-16$ & \\
\hline & Ra-228 & $1.32 \mathrm{E}-15$ & \\
\hline & Th-228 & $1.37 \mathrm{E}-16$ & \\
\hline Total Cm-244 & & $1.18 \mathrm{E}-02$ & $5,979.2$ \\
\hline Сo-60 & & $0.00 \mathrm{E}+00$ & \\
\hline Cs-134 & & $0.00 \mathrm{E}+00$ & \\
\hline Cs-137 & & $0.00 \mathrm{E}+00$ & \\
\hline $\mathrm{Eu}-152$ & & $0.00 \mathrm{E}+00$ & \\
\hline $\mathrm{Eu}-154$ & & $0.00 \mathrm{E}+00$ & \\
\hline Eu-155 & & $0.00 \mathrm{E}+00$ & \\
\hline \multirow[t]{4}{*}{$\mathrm{Pu}-238(\mathrm{U}-234)$} & & 7.71E-06 & \\
\hline & Th-230 & $1.45 \mathrm{E}-07$ & \\
\hline & $\mathrm{Ra}-226$ & $1.83 \mathrm{E}-08$ & \\
\hline & $\mathrm{Pb}-210$ & $4.00 \mathrm{E}-08$ & \\
\hline Total Pu-238 & & 7.91E-03 & 475.07 \\
\hline \multirow[t]{4}{*}{ Pu-239 } & & 8.24E-02 & \\
\hline & U-235 & $9.86 \mathrm{E}-08$ & \\
\hline & $\mathrm{Pa}-231$ & $6.31 \mathrm{E}-08$ & \\
\hline & Ac- 227 & $4.21 \mathrm{E}-08$ & \\
\hline Total Pu-239 & & $8.24 \mathrm{E}+01$ & $5,979.2$ \\
\hline Sr-90 & & $1.57 \mathrm{E}-65$ & $6,518.6$ \\
\hline
\end{tabular}


Table A-15. (continued).

\begin{tabular}{|c|c|c|c|}
\hline Radionuclide & Progeny & $\begin{array}{l}\text { Drinking Water EDE } \\
\text { (mrem) }\end{array}$ & $\begin{array}{c}\text { Time of Peak After Start of Simulation } \\
\text { (years) }\end{array}$ \\
\hline Th-228 & & $0.00 \mathrm{E}+00$ & \\
\hline \multirow[t]{3}{*}{ Th-230 } & & 5.29E-05 & \\
\hline & Ra-226 & 7.07E-05 & \\
\hline & $\mathrm{Pb}-210$ & $1.76 \mathrm{E}-04$ & \\
\hline Total Th-230 & & 3.00E-01 & 27,024 \\
\hline \multirow[t]{3}{*}{ Th-232 } & & 2.94E-05 & \\
\hline & $\mathrm{Ra}-228$ & $8.90 \mathrm{E}-05$ & \\
\hline & Th-228 & $9.19 \mathrm{E}-06$ & \\
\hline Total Th-232 & & $1.28 \mathrm{E}-01$ & 27,024 \\
\hline \multirow[t]{4}{*}{ U-234 } & & 4.14E-03 & \\
\hline & Th-230 & 7.79E-05 & \\
\hline & Ra-226 & $9.81 \mathrm{E}-06$ & \\
\hline & $\mathrm{Pb}-210$ & $2.14 \mathrm{E}-05$ & \\
\hline Total U-234 & & $4.25 \mathrm{E}+00$ & 475.07 \\
\hline \multirow[t]{3}{*}{ U-235 } & & 4.19E-05 & \\
\hline & $\mathrm{Pa}-231$ & 4.30E-06 & \\
\hline & Ac-227 & $2.71 \mathrm{E}-06$ & \\
\hline Total U-235 & & $4.89 \mathrm{E}-02$ & 475.07 \\
\hline \multirow[t]{5}{*}{ U-238 } & & $1.60 \mathrm{E}-03$ & \\
\hline & U-234 & $2.39 \mathrm{E}-06$ & \\
\hline & Th-230 & $2.25 \mathrm{E}-08$ & \\
\hline & Ra-226 & 1.92E-09 & \\
\hline & $\mathrm{Pb}-210$ & 3.94E-09 & \\
\hline Total U-238 & & $1.60 \mathrm{E}+00$ & 475.07 \\
\hline
\end{tabular}

The re-analysis of groundwater concentrations for retained radionuclides in contaminated surface soils was conducted first. Parameters used for the contaminated soils were assumed to be equal to those used in the groundwater assessment for candidate Site 5 shown in Table A-11. The sediment distribution was assigned as discussed in Section A-6.3. All-pathways dose factors used the model described in DOEID (2007) $)^{b}$ and dose coefficients from FGR-13 (EPA 2002). The infiltration rate history through the contaminated soils was similar to that used in the re-analysis of dose at NRF. This is consistent with the primary contaminated soils inventories being associated with the warm waste ponds, accounting for any potential increase in flow through them prior to the time of remediation and the following 100 years. Thus, the infiltration rate was assumed to begin at $18 \mathrm{~cm} /$ year, derived from the analyses of neutron probe data in the INTEC tank farm (DOE-ID 2006a), linearly decreasing to an ambient background level of $1 \mathrm{~cm} /$ year during the first 100 years of simulation. Other model parameters are summarized in Table A-16.

\footnotetext{
${ }^{\mathrm{b}}$ The all-pathways dose model in DOE-ID 2007, DOE-ID 2010, DOE-ID 2003a, and DOE-ID 2003b are identical. The dose coefficients used in DOE-ID 2003a and DOE-ID 2003b were from EPA 1998 while the dose coefficients used in DOE-ID 2007 and DOE-ID 2010 were from EPA 2002.
} 
Table A-16. Input parameters for the re-analysis of contaminated soils sources at the Advanced Test Reactor Complex.

\begin{tabular}{|c|c|c|}
\hline Parameter Description & Value & Comments \\
\hline $\begin{array}{l}\text { Source length parallel to } \\
\text { groundwater flow }\end{array}$ & $286 \mathrm{~m}$ & Comprehensive RI/FS for WAG 2 DOE/ID-10531 (DOE-ID 1997a) \\
\hline $\begin{array}{l}\text { Source width perpendicular to } \\
\text { groundwater flow }\end{array}$ & $286 \mathrm{~m}$ & Comprehensive RI/FS for WAG 2 DOE/ID-10531 (DOE-ID 1997a) \\
\hline Receptor distance & 143 & One-half the source length \\
\hline Infiltration, 0 to 100 years & $\begin{array}{l}18 \mathrm{~cm} / \text { year linearly } \\
\text { decreasing to } \\
1 \mathrm{~cm} / \text { year }\end{array}$ & $\begin{array}{l}\text { Conservatively assumed based on infiltration through disturbed soils } \\
\text { at INTEC }\end{array}$ \\
\hline Infiltration, greater than 100 years & $1 \mathrm{~cm} /$ year & Background infiltration in undisturbed soil \\
\hline Unsaturated lithology, 0 to $12 \mathrm{~m}$ & 6 cells, $2.0 \mathrm{~m} /$ cell & High-permeability alluvium \\
\hline Unsaturated lithology, 12 to $38 \mathrm{~m}$ & 18 cells, $2.0 \mathrm{~m} /$ cell & $\begin{array}{l}\text { Unsaturated basalt, based on analysis of the drill log for the ATR } \\
\text { Complex disposal well }\end{array}$ \\
\hline Unsaturated lithology, 38 to $58 \mathrm{~m}$ & 10 cells, $2.0 \mathrm{~m} /$ cell & $\begin{array}{l}\text { Interbed, based on analysis of the drill log for the ATR Complex } \\
\text { disposal well. }\end{array}$ \\
\hline $\begin{array}{l}\text { Unsaturated lithology, } 58 \text { to } 142 \\
\mathrm{~m}\end{array}$ & 36 cells, $2.0 \mathrm{~m} /$ cell & $\begin{array}{l}\text { Unsaturated basalt, based on analysis of the drill log for the ATR } \\
\text { Complex disposal well }\end{array}$ \\
\hline Unsaturated dispersivity & $1.01 \mathrm{~m}$ & $\begin{array}{l}\text { Implicit dispersion calculated with Equation } 24 \text { in Rood }(2005) \text { as } \alpha= \\
Z / 2 N \text { where } \mathrm{Z}=\text { unsaturated thickness }(142 \mathrm{~m}) \text { and } N=\text { number of } \\
\text { cells (70) }\end{array}$ \\
\hline Darcy Velocity in aquifer & $21 \mathrm{~m} /$ year & Site 5 Darcy velocity \\
\hline Aquifer porosity & 0.06 & OU 10-08 (DOE-ID 2008) \\
\hline Bulk density of aquifer & $1.9 \mathrm{~g} / \mathrm{cm}^{3}$ & DOE-ID (1994, p. C-11) \\
\hline Longitudinal dispersivity & $9 \mathrm{~m}$ & DOE-ID 1994 (Track 2 Guidance) \\
\hline Transverse dispersivity & $4 \mathrm{~m}$ & DOE-ID 1994 (Track 2 Guidance) \\
\hline
\end{tabular}

The predicted peak radionuclide groundwater concentrations and all-pathways dose for the re-analysis of the contaminated soils in the ATR Complex are shown in Table A-17. These doses are all well below the dose limit of $25 \mathrm{mrem} /$ year specified by DOE Order 435.1. The magnitude of these doses suggest that contaminated soils at the ATR Complex have no potential to significantly impact the groundwater at proposed Site 5 for the RH-LLW disposal facility.

Table A-17. Predicted peak radionuclide groundwater concentrations and all-pathways dose for the re-analysis of Advanced Test Reactor Complex surface soil contamination.

\begin{tabular}{|c|c|c|c|}
\hline $\begin{array}{c}\text { Radionuclide } \\
\text { (Progeny on right) }\end{array}$ & $\begin{array}{l}\text { Peak Groundwater } \\
\text { Concentration } \\
(\mathrm{pCi} / \mathrm{L})\end{array}$ & $\begin{array}{l}\text { Time of Peak After Start of } \\
\text { Simulation } \\
\text { (years) }\end{array}$ & $\begin{array}{l}\text { Peak All-Pathways Dose } \\
\text { (mrem/year EDE) }\end{array}$ \\
\hline U-238 & $3.55 \mathrm{E}-02$ & 29,750 & $5.15 \mathrm{E}-03$ \\
\hline U-234 & $2.96 \mathrm{E}-03$ & 31,750 & 4.39E-04 \\
\hline Th-230 & $9.94 \mathrm{E}-06$ & 48,750 & $6.01 \mathrm{E}-06$ \\
\hline $\mathrm{Ra}-226$ & $9.74 \mathrm{E}-06$ & 52,750 & $8.05 \mathrm{E}-06$ \\
\hline $\mathrm{Pb}-210$ & $1.32 \mathrm{E}-05$ & 52,750 & $9.72 \mathrm{E}-04$ \\
\hline U-238 Total & N/A & 30,750 & $5.88 \mathrm{E}-03$ \\
\hline
\end{tabular}


Table A-17. (continued).

\begin{tabular}{|c|c|c|c|}
\hline $\begin{array}{c}\text { Radionuclide } \\
\text { (Progeny on right) }\end{array}$ & $\begin{array}{l}\text { Peak Groundwater } \\
\text { Concentration } \\
(\mathrm{pCi} / \mathrm{L})\end{array}$ & $\begin{array}{l}\text { Time of Peak After Start of } \\
\text { Simulation } \\
\text { (years) }\end{array}$ & $\begin{array}{l}\text { Peak All-Pathways Dose } \\
\text { (mrem/year EDE) }\end{array}$ \\
\hline U-234 & $7.60 \mathrm{E}-02$ & 29,750 & $1.12 \mathrm{E}-02$ \\
\hline Th-230 & $2.50 \mathrm{E}-04$ & 46,750 & $1.51 \mathrm{E}-04$ \\
\hline $\mathrm{Ra}-226$ & $2.45 \mathrm{E}-04$ & 50,750 & 2.03E-04 \\
\hline $\mathrm{Pb}-210$ & $3.33 \mathrm{E}-04$ & 50,750 & $2.45 \mathrm{E}-02$ \\
\hline U-234 Total & N/A & 41,750 & 2.72E-02 \\
\hline Th-230 & $4.02 \mathrm{E}-10$ & 314,000 & $2.43 \mathrm{E}-10$ \\
\hline Ra-226 & $4.11 \mathrm{E}-10$ & 314,000 & $3.39 \mathrm{E}-10$ \\
\hline $\mathrm{Pb}-210$ & $5.58 \mathrm{E}-10$ & 314,000 & $4.10 \mathrm{E}-08$ \\
\hline Th-230 Total & N/A & 314,000 & 4.16E-08 \\
\hline $\mathrm{Pu}-239$ & $1.43 \mathrm{E}-15$ & 314,000 & $1.01 \mathrm{E}-15$ \\
\hline U-235 & $5.95 \mathrm{E}-05$ & 41,750 & $8.40 \mathrm{E}-06$ \\
\hline $\mathrm{Pa}-231$ & $5.55 \mathrm{E}-07$ & 70,750 & $7.54 \mathrm{E}-07$ \\
\hline Ac- 227 & $7.30 \mathrm{E}-07$ & 71,750 & $2.20 \mathrm{E}-05$ \\
\hline Pu-239 Total & N/A & 63,750 & $2.74 \mathrm{E}-05$ \\
\hline
\end{tabular}

The inventory of radionuclides estimated to reside in the perched water and associated sediment also was assessed. Infiltration through the perched water zone is caused primarily by discharges to the ponds at the ATR Complex. To account for this higher infiltration region, infiltration for the first 50 years was assigned a value of $18 \mathrm{~m} /$ year. This was derived by dividing the horizontal extent of the warm waste ponds by the average historical water discharge rate. The horizontal extent of the warm waste ponds is roughly $152 \mathrm{~m} \times 304 \mathrm{~m}$. Discharges to the ponds averaged $8.5 \mathrm{E} 5 \mathrm{~m}^{3} /$ year, for an average infiltration rate of $18 \mathrm{~m} /$ year. The lateral extent of perched water was estimated to be $1,000 \mathrm{~m} \times 500 \mathrm{~m}$. It was assumed that the perched water was uniformly influenced by pond discharges. Averaged over the perched water extent, this yields an average infiltration rate of $1.8 \mathrm{~m} /$ year. In the evaluation of groundwater concentrations for radionuclides currently in the perched water, it was assumed that pond discharges would continue to recharge the perched water for an additional 50 years. After 50 years, it was assumed that discharges to the pond would cease and infiltration would revert to the background rate of $1 \mathrm{~cm} /$ year. Other model parameters are summarized in Table A-18.

Table A-18. Input parameters for the re-analysis of perched water at the Advanced Test Reactor Complex.

\begin{tabular}{|c|c|c|}
\hline Parameter Description & Value & Comments \\
\hline $\begin{array}{l}\text { Source length parallel to } \\
\text { groundwater flow }\end{array}$ & $1000 \mathrm{~m}$ & Estimated extent of perched water body \\
\hline $\begin{array}{l}\text { Source width perpendicular to } \\
\text { groundwater flow }\end{array}$ & $500 \mathrm{~m}$ & Estimated extent of perched water body \\
\hline Receptor distance & 500 & One-half the source length \\
\hline Infiltration to ponds 0 to 50 years & $18 \mathrm{~m} /$ year & $\begin{array}{l}\text { Based on } 3 \times 10^{7} \mathrm{ft}^{3} / \text { year }\left(8.49 \times 10^{5} \mathrm{~m}^{3} / \text { year }\right) \text { water flux to the pond } \\
\text { spread over } 152 \mathrm{~m} \times 304 \mathrm{~m}\end{array}$ \\
\hline $\begin{array}{l}\text { Infiltration to ponds greater than } \\
50 \text { years }\end{array}$ & $0.01 \mathrm{~m} /$ year & Background infiltration rate for INL \\
\hline Infiltration through interbeds & variable & $\begin{array}{l}\text { Water flux from the ponds is spread over the lateral region of the } \\
\text { perched water }(1,000 \mathrm{~m} \times 500 \mathrm{~m}) \text {. After } 50 \text { years, infiltration has a } \\
\text { minimum value of } 0.01 \mathrm{~m} / \text { year }\end{array}$ \\
\hline
\end{tabular}


Table A-18. (continued).

\begin{tabular}{|c|c|c|}
\hline Parameter Description & Value & Comments \\
\hline Unsaturated lithology, 0 to $12 \mathrm{~m}$ & 6 cells, $2.0 \mathrm{~m} / \mathrm{cell}$ & $\begin{array}{l}\text { High-permeability alluvium, based on analysis of the drill } \log \text { for the } \\
\text { ATR Complex disposal well }\end{array}$ \\
\hline Unsaturated lithology, 12 to $38 \mathrm{~m}$ & 18 cells, $2.0 \mathrm{~m} / \mathrm{cell}$ & $\begin{array}{l}\text { Unsaturated basalt, based on analysis of the drill log for the ATR } \\
\text { Complex disposal well }\end{array}$ \\
\hline Unsaturated lithology, 38 to $58 \mathrm{~m}$ & 10 cells, $2.0 \mathrm{~m} / \mathrm{cell}$ & $\begin{array}{l}\text { Interbed, based on analysis of the drill log for the ATR Complex } \\
\text { disposal well. }\end{array}$ \\
\hline $\begin{array}{l}\text { Unsaturated lithology, } 58 \text { to } \\
142 \mathrm{~m}\end{array}$ & 36 cells, $2.0 \mathrm{~m} / \mathrm{cell}$ & Unsaturated basalt \\
\hline Unsaturated dispersivity & $1.01 \mathrm{~m}$ & $\begin{array}{l}\text { Implicit dispersion calculated with Equation } 24 \text { in Rood (2005) as } \alpha= \\
Z / 2 N \text { where } \mathrm{Z}=\text { unsaturated thickness }(142 \mathrm{~m}) \text { and } N=\text { number of } \\
\text { cells (70) }\end{array}$ \\
\hline Darcy velocity in aquifer & $21 \mathrm{~m} /$ year & Site 5 Darcy velocity \\
\hline Aquifer porosity & 0.06 & OU 10-08 (DOE-ID 2008) \\
\hline Bulk density of aquifer & $1.9 \mathrm{~g} / \mathrm{cm}^{3}$ & DOE-ID (1994, p. C-11) \\
\hline Longitudinal dispersivity & $9 \mathrm{~m}$ & DOE-ID (1994, p. C-11) \\
\hline Transverse dispersivity & $4 \mathrm{~m}$ & DOE-ID (1994, p. C-11) \\
\hline
\end{tabular}

Predicted peak concentrations, all-pathways EDE, and the time of peak for the radionuclides contained in the perched water are shown in Table A-19. Strontium accounts for the highest dose contribution from the perched water and, with its relatively short half-life, it is not expected to remain in the aquifer during the period of interest to the RH-LLW disposal facility. Other radionuclides currently in the perched water have very low dose contributions at the ATR Complex boundary and will only decrease during aquifer transport as a result of dilution and dispersion.

Table A-19. Predicted peak radionuclide groundwater concentrations and all-pathways EDE for the re-analysis of Advanced Test Reactor perched water contamination, using MCM and GWSCREEN, using revised sediment and basalt properties and $K_{d}$ values in A-9.

\begin{tabular}{l|ccc}
\hline \multicolumn{1}{c|}{ Radionuclide } & $\begin{array}{c}\text { Peak Groundwater Concentration } \\
(\mathrm{pCi} / \mathrm{L})\end{array}$ & $\begin{array}{c}\text { Peak All-Pathways Dose } \\
\text { (mrem/year EDE) }\end{array}$ & $\begin{array}{c}\text { Time of Peak } \\
\text { After Start of Simulation } \\
\text { (years) }\end{array}$ \\
\hline Am-241 & $2.26 \mathrm{E}-11$ & $1.31 \mathrm{E}-11$ & 52 \\
$\quad$ Np-237 & $1.63 \mathrm{E}-08$ & $4.99 \mathrm{E}-09$ & 9,910 \\
U-233 & $7.88 \mathrm{E}-09$ & $1.21 \mathrm{E}-09$ & 9,910 \\
Th-229 & $2.95 \mathrm{E}-11$ & $5.37 \mathrm{E}-11$ & 9,910 \\
Am-241 Total & & $6.25 \mathrm{E}-09$ & 9,910 \\
Co-60 & $8.18 \mathrm{E}-11$ & $3.62 \mathrm{E}-12$ & 51 \\
Sr-90 & $1.16 \mathrm{E}-04$ & $1.52 \mathrm{E}-05$ & 51 \\
Total & & $1.52 \mathrm{E}-05$ & 52 \\
\hline
\end{tabular}

\section{A-8. ASSESSMENT AND RECOMMENDATIONS}

Largely because parameterization and transport understanding have evolved over time at the INL Site and because of the built-in conservatism used in the CERCLA assessments, it was necessary to re-evaluate predicted groundwater concentrations for radionuclide sources upgradient of Candidate Site 5 for the onsite alternative RH-LLW disposal facility. This re-evaluation of concentrations was extended to include the computation of all-pathways doses based on the guidance provided in FRG-13 (EPA 2002). Re-computed 
concentrations indicate that the initial CERCLA analyses of unmitigated sites conducted for WAG 2 and WAG 8 are very conservative and that the contaminated soils and perched water at those facilities have no significant potential to impact groundwater under NRF or the ATR Complex. Further, because Candidate Site 5 is downgradient of both facilities, sources at NRF and the ATR Complex will only decrease in their significance to the proposed onsite RH-LLW disposal facility.

Recommendations from this evaluation are to use the more current parameters for infiltration, sorption, and dose coefficient for site-specific evaluations at INL. To accomplish site-specific evaluations, subsurface sedimentary structure should be accounted for. The predicted doses from NRF and the ATR Complex provided in this assessment should be used in composite analyses at INL for downgradient locations.

\section{A-9. REFERENCES}

40 CFR 141, "National Primary Drinking Water Regulations," Code of Federal Regulations, June 2010.

Cecil, L. D., J. R. Pittman, T. M. Beasley, R. L. Michel, P. W. Kubik, P. Sharma, U. Fehn, and H. Gove, 1992, "Water Infiltration Rates in the Unsaturated Zone at the Idaho National Engineering Laboratory Estimated by Chlorine-36 and Tritium Profiles, and Neutron Logging," in Proceedings of the $7^{\text {th }}$ International Symposium on Water-Rock Interactions, WRI-7, Y. K. Kharaka and A. S. Meest, eds., Park City, Utah, July 13-18, 1992.

Dames and Moore, 1992, Remedial Investigation Report for the Test Reactor Area Perched Water System (Operable Unit 2-12), EGG-WM-10002, Revision 0, Idaho National Engineering and Environmental Laboratory, June 1992.

DOE Order 435.1, Change 1, 2001, "Radioactive Waste Management,” U.S. Department of Energy, August 28, 2001.

DOE-ID, 1994, Track 2 Sites: Guidance for Assessing Low Probability Hazard Sites at the INEL, DOE/ID10389, U.S. Department of Energy Idaho Operations Office, January 1994.

DOE-ID, 1997a, Comprehensive Remedial Investigation/Feasibility Study for the Idaho Chemical Processing Plant Operable Unit 3-13 at the INEEL-Part A, DOE/ID-10534, U.S. Department of Energy Idaho Operations Office.

DOE-ID, 1997b, Comprehensive Remedial Investigation/Feasibility Study for the Idaho Test Reactor Area Operable Unit 2-13 at the Idaho National Engineering and Environmental Laboratory, DOE/ID10531, U.S. Department of Energy Idaho Operations Office.

DOE-ID, 1997c, Final Record of Decision, Test Reactor Area, Operable Unit 2-13, DOE/ID-10586, Revision 0, U.S. Department of Energy Idaho Operations Office, December 1997.

DOE-NR, 1998, Final Record of Decision, Naval Reactors Facility, Operable Unit 8-08, Idaho National Engineering and Environmental Laboratory, Idaho Falls, Idaho, Administrative Record No. AR5.110544, DOE Naval Reactors Idaho Branch Office; EPA, Region 10; Idaho Department of Health and Welfare, Division of Environmental Quality, September 1998.

DOE-ID, 2003a, Performance Assessment for the INEEL CERCLA Disposal Facility Landfill (Draft), DOE/ID-10978, Rev. 1, Draft A, U.S. Department of Energy Idaho Operations Office, March 2010.

DOE-ID, 2003b, Composite Analysis for the INEEL CERCLA Disposal Facility Landfill, DOE/ID-10979, U.S. Department of Energy Idaho Operations Office, August 2003. 
DOE-ID, 2003c, Phase I Monitoring Well and Tracer Study Report for Operable Unit 3-13, Group 4, Perched Water, DOE/ID-10967, U.S. Department of Energy Idaho Operations Office, June 2003.

DOE-ID, 2004, Spatial Variability of Sedimentary Interbed Properties Near the INTEC at the INEEL, Knobel, L. L., USGS Water Resources Investigation Report 03-4142, also as DOE/ID-22187, U.S. Department of Energy Idaho Operations Office, 2004.

DOE-ID, 2006a, Operable Unit 3-14 Tank Farm Soil and Groundwater Remedial Investigation/Baseline Risk Assessment, DOE/ID-11227, U.S. Department of Energy Idaho Operations Office, April 2006.

DOE-ID, 2006b, Remedial Investigation and Baseline Risk Assessment for Operable Unit 7-13/14, DOE/ID-11241, Rev. 0, U.S. Department of Energy Idaho Operations Office, May 2006.

DOE-ID, 2007, Performance Assessment for the RWMC Active Low-Level Waste Disposal Facility at the Idaho National Laboratory Site, DOE/NE-ID-11243, U.S. Department of Energy Idaho Operations Office, September 2007.

DOE-ID, 2008, Operable Unit 10-08 Sitewide Groundwater and Miscellaneous Sites Remedial Investigation/Baseline Risk Assessment (RI/BRA), DOE/ID-11332, U.S. Department of Energy Idaho Operations Office, April 2008.

DOE-ID, 2010, Performance Assessment for the Idaho CERCLA Disposal Facility (DRAFT), DOE/ID-10978, U.S. Department of Energy Idaho Operations Office.

Doornbos, M. H, J. L. Mattick, D. L. McElroy, L. V. Street, C. S. Blackmore, and C. A. Dicke, 1991, Environmental Characterization Report for the Test Reactor Area, EGG-WM-9690, Rev. 0, Idaho National Engineering Laboratory, September 1991.

Envirodyne Engineers, 1988, Engineering Report for Services with the NRF Industrial Waste Ditch Remedial Action Plan, INEL, prepared for WEC under Subcontract C86-131239.

EPA, 1988, "Limiting Values of Radionuclide Intake and Air Concentration and Dose Conversion Factors for Inhalation, Submersion, and Ingestion; Federal Guidance Report 11,” EPA-520/1-88-020, U.S. Environmental Protection Agency, Office of Radiation Programs, 1988.

EPA, 1999, Cancer Risk Coefficients for Environmental Exposure to Radionuclides"; Federal Guidance Report 13, Revision 1, EPA-402-R-99-001, U.S. Environmental Protection Agency, Office of Radiation and Indoor Air, 1999.

EPA, 2002, Cancer Risk Coefficients for Environmental Exposure to Radionuclide, Federal Guidance Report 13, EPA 402-R-99-001, U. S. Environmental Protection Agency, Office of Radiation Programs, CD Supplement, April 2002.

Gelhar, L. W., 1986, "Stochastic Subsurface Hydrology from Theory to Applications," Water Resources Research, Vol. 22, No. 9, August 1986 Supplement, pp. 135S-145S.

Helm-Clark, C., S. Ansley, T. McLing, and T. Wood, 2005, Borehole and Well Middle-1823 and Its Relationship to the Stratigraphy of the South-Central Idaho National Laboratory, ICP/EXT-05-00790, March 2005. 
INEL, 1995, Work Plan for Waste Area Group 2 Operable Unit 2-13 Comprehensive Remedial Investigation/Feasibility Study, INEL-94/0026, Revision 0, Idaho National Laboratory, April 1995.

INL, 2010a, Evaluation of Sedimentary Structure Near the Advance Test Reactor Complex at the Idaho National Laboratory, INL/EXT-10-18762, Idaho National Laboratory.

INL, 2010b, Assessment of Geochemical Environment for the Proposed INL Remote-Handled Low-Level Waste Disposal Facility, INL/EXT-10-19385, Idaho National Laboratory.

Jenkins, T., 2001, U.S. Department of Energy Idaho Operations Office, letter, to Marty Doornbos, Idaho National Engineering and Environmental Laboratory, July 3, 2001, "Kd Values for INTEC Groundwater Modeling," EM-ER-01-115.

Magnuson, S. O., 1995, Inverse Modeling for Field-Scale Hydrologic and Transport Parameters of Fractured Basalt, INEL-95/0637, Idaho National Engineering Laboratory.

Martian, P., 1995, UNSAT-H Infiltration Model Calibration at the Subsurface Disposal Area, Idaho National Engineering Laboratory, INEL-95/0596, Idaho National Engineering Laboratory.

Martian, P. and S. O. Magnuson, 1994, A Simulation Study of Infiltration Into Surficial Sediments at the Subsurface Disposal Area, Idaho National Engineering Laboratory, EGG-WM-11250, Idaho National Engineering and Environmental Laboratory.

Mattson, E., M. Ankeny, S. Dwyer, N. Hampton, G. Matthern, B. Pace, A. Parsons, M. Plummer, S. Reese, and J. Waugh, 2004, Preliminary Design for an Engineered Surface Barrier at the Subsurface Disposal Area, ICP/EXT-04-00216, Idaho National Engineering and Environmental Laboratory, Idaho Completion Project.

Rood, A. S., 2003, GWSCREEN: A Semi-Analytical Model for Assessment of the Groundwater Pathway from Surface or Buried Contamination, Theory and User's Manual, Version 2.5, INEEL/EXT-98-00750, Idaho National Engineering and Environmental Laboratory, April 2003.

Rood, A. S., 2005, Mixing Cell Model: A One-Dimensional Numerical Model for Assessment of Water Flow and Contaminant Transport in the Unsaturated Zone, ICP/EXT-05-00748, Revision 0, Idaho Completion Project, Idaho Falls, March 2005.

Wood, T. R., C. M. Helm-Clark, H. Huang, S. Magnuson, T. McLing, B. Orr, M. J. Rohe, M. A. Plummer, R. Podgorney, E. Whitmore, and M. S. Roddy, 2007, Development Report on the Idaho National Laboratory Sitewide Three-Dimensional Aquifer Model, INL/EXT-07-13337, U.S. Department of Energy Idaho Operations Office, September 2007.

Westinghouse, 1997, Final NRF Comprehensive Remedial Investigation/Feasibility Study, Waste Area Group 8, Naval Reactors Facility, Idaho Falls, Idaho, DOE/ID-10432, Volumes 1 through 3, October 1997.

WEC, 1994, Final Remedial Investigation/Feasibility Study for the Exterior Industrial Waste Ditch Operable Units 8-07, Naval Reactors Facility, Idaho Falls, Idaho, September, 1994. 